JESNER SERENI ILDEFONSO

\title{
PROPOSTA DE UM SISTEMA DE GERÊNCIA PARA VIAS FÉRREAS BRASILEIRAS
}

Tese apresentada à Escola de Engenharia de São Carlos, da Universidade de São Paulo, como parte dos requisitos para a obtenção do Título de Doutor em Ciências no Programa de Pós-Graduação em Transportes.

Orientador: Prof. Dr. José Leomar Fernandes Jr.

São Carlos

2013 


\section{AUTORIZO A REPRODUÇÃO TOTAL OU PARCIAL DESTE TRABALHO, POR QUALQUER MEIO CONVENCIONAL OU ELETRÔNICO, PARA FINS DE ESTUDO E PESQUISA, DESDE QUE CITADA A FONTE.}

Ildefonso, Jesner Sereni

I27p Proposta de um sistema de gerência para vias férreas brasileiras / Jesner Sereni Ildefonso; orientador José Leomar Fernandes Júnior. São Carlos, 2013.

Tese (Doutorado) - Programa de Pós-Graduação em Engenharia de Transportes e Área de Concentração em Infra-Estrutura de Transporte -- Escola de Engenharia de São Carlos da Universidade de São Paulo, 2013.

1. Ferrovias. 2. Gerência de vias. 3. Índices de qualidade. 4. Geometria ferroviária. 5. Superestrutura ferroviária. 6. Defeitos. I. Título. 


\section{FOLHA DE JULGAMENTO}

\section{Candidato: Engenheiro JESNER SERENI ILDEFONSO.}

Título da tese: "Proposta de um sistema de gerência para vias férreas brasileiras".

Data da defesa: 07/02/2013

Comissão Julgadora:

Prof. Associado José Leomar Fernandes Júnior (Orientador) (Escola de Engenharia de São Carlos/EESC)

Prof. Dr. Glauco Túlio Pessa Fabbri

(Escola de Engenharia de São Carlos/EESC)

Prof ${ }^{\mathrm{a}}$. Dr ${ }^{\mathrm{a}}$. Sandra Oda

(Universidade Federal do Rio de Janeiro/UFRJ)

Prof ${ }^{\text {a }}$. Dr ${ }^{\text {a }}$. Eliane Viviani

(Universidade Federal de São Carlos/UFSCar)

Prof. Dr. Ernesto Ferreira Nobre Junior

(Universidade Federal do Ceará/UFC)

\section{Resultado:}

APROVA DO

APNOYADO

APROVADO

APROV ADO

APROVADO

Coordenador do Programa de Pós-Graduação em Engenharia de Transportes: Prof. Associado Antônio Nélson Rodrigues da Silva 

Dedico esta obra à minha família, que sempre me proveu apoio, amor, incentivo e segurança, fatores estes que me permitiram chegar ao final deste trabalho. 

A história da ciência, como história de todas as ideias humanas, é feita de sonhos irresponsáveis, de erros e de obstinação. Mas a ciência é uma das poucas atividades humanas - talvez a única - em que os erros são criticados sistematicamente (e com frequência corrigidos). Por isso podemos dizer que, no campo da ciência, aprendemos muitas vezes com nossos erros.

(Karl Popper) 

I get by with a little help from my friends,

Gonna try with a little help from my friends

(PaulMcCartney)

\section{Acrabecmenros}

A Deus, por ter me dado força e coragem para vencer os muitos obstáculos que apareceram nesta jornada.

Ao professor Dr. José Leomar Fernandes Jr., pelos anos de amizade, apoio, ensinamentos, compreensão e auxílio dispensados nesta empreitada que começou com o trabalho de mestrado e que perdurará por muitos anos e trabalhos ainda por vir.

Aos professores Dr. Adalberto Leandro Faxina e Dra. Eliane Viviani, pelas sugestões, confiança e cuidados dispensados no exame de qualificação.

Ao engenheiro Lucas Vinícius Fukagawa, pela indicação e contato com a empresa concessionária dos trechos estudados. 
Ao professor Dr. Paulo César Lima Segantine, pela amizade, aconselhamentos e momentos de descontração.

Às funcionárias Heloísa Helena B. P. M. Belo e Elizabeth Regina Zambon Ortegado, da secretaria do Departamento de Transportes da Escola de Engenharia de São Carlos, pelo apoio administrativo neste trabalho e amizade.

Aos funcionários e amigos Antônio Carlos Gigante, Paulo Toyama, João Domingos Pereira Filho, Alexandre Reis de Oliveira, Antônio Carlos Mariano, Magaly Bruno Marcondes César, Paulo Sérgio Batista, pela ajuda, amizade e momentos de alegria.

Aos professores do Departamento de Transportes da Escola de Engenharia de São Carlos, pelos conhecimentos transferidos e apoio técnico, em especial ao professor Dr. Antônio Nélson Rodrigues da Silva, pelos cuidados e preocupação.

Aos amigos e "irmãos de sala" Sérgio Soncim, Vivian Bardini, Fábio Zanchetta, Mateus Dezotti, Diego Nunes e Amanda Eler pelo convívio diário repleto de companheirismo, incentivo, ajuda, desabafos e risadas.

Aos amigos do Departamento de Transportes da Escola de Engenharia de São Carlos pelos ótimos momentos vividos juntos, Ana Furlan, André Cunha, Bruno Bertoncini, Francis Kakuda, Leandro Piassi, Luís Miguel, Mateus Araújo, Paulo Reschetti.

Aos colegas do Departamento de Transportes da Escola de Engenharia de São Carlos que me acompanharam ao longo do doutoramento, Alex, Ana Paula Magalhães, Andressa Ng, Daniel Anijar, Denise Machado, Dinato, Fabíola Aguiar, Fernanda Pilati, Fernando Hirose, Gustavo Andrade, Iara Alves, Isabela Fornaciari, Joicy Poloni, José Elievam, Karla Cristina, Ligia Gesteira, Luciana Spigolon, Madalena Ribeiro, Marcela Navarro, Marcelo Mancini, Mário Azevedo, Monique Gomes, Pablo Sousa, Robert Becerra, Rochele, Simone Lopes, Talita Caetano, Thais Guerreiro, Victor Frazão e Tiago Bastos. 
Ao Departamento de Engenharia Civil da Universidade Estadual de Maringá, em especial para os professores Dr. José Kiynha Yshiba e Dr. Jeselay Hemetério Cordeiro dos Reis, pelo apoio e incentivo à realização deste trabalho.

Ao Conselho Nacional de Desenvolvimento Científico e Tecnológico (CNPq), pela bolsa de estudo concedida.

Às pessoas que têm, tiveram e sempre terão papel fundamental na minha vida:

Daniela Mortari, pelos ótimos momentos juntos, pelo carinho e incentivo ao longo desses anos.

Meus amigos-irmãos Eduardo Moreira, Ricardo Bardalati, Mauro Gattamorta e Marcelo Gonsales, que sempre estiveram ao meu lado.

Meus familiares, Tia Sueli, Tio Toninho, tio Celso, tia Penha, Diogo e Diana, pelo apoio incondicional, carinho e alegrias.

Meus irmãos, Élder e Cléber, aos quais me ponho como referência e que são as alegrias da minha vida.

Minha avó Olívia e meu avô Orlando (in memorian), pelo papel fundamental na formação da pessoa que sou hoje e pelo amor sem fronteiras.

Meus pais, Élcio e Iracy, referências em minha vida e que traduzem o verdadeiro significado de família no nosso dia a dia. 



\section{ILDEFONSO, J. S. Proposta de um sistema de gerência para vias férreas} brasileiras. 2012. 171 p. Tese (Doutorado) - Escola de Engenharia de São Carlos, Universidade de São Paulo, São Carlos, 2012.

O sistema ferroviário brasileiro é constituído por uma malha de aproximadamente 30 mil quilômetros de ferrovias, nas quais percorrem mais de 2,9 mil locomotivas e 92 mil vagões, responsáveis pelo transporte de cerca $23 \%$ da carga do país; a matriz de transportes está distorcida, uma vez que nos países desenvolvidos esse modo responde por cerca de $40 \%$ da carga transportada. A manutenção de via permanente responde por $12 \%$ a $30 \%$ do custo de operação de uma via férrea e nas ferrovias brasileiras, esse gasto ficou em torno de 300 milhões de dólares no ano de 2000, evidenciando que simples melhorias no modo como as manutenções são realizadas, implicam em grande economia para o setor. Há basicamente três tipos de manutenções passíveis de serem executadas: manutenção corretiva, manutenção preventiva e manutenção preditiva. Com o uso da gerência de vias férreas é possível determinar qual manutenção é a mais apropriada e quando se deve executá-la, de forma a utilizar os recursos financeiros disponíveis da melhor forma possível. O foco desta pesquisa está no estudo da via férrea com relação à geometria e à condição estrutural dos elementos da superestrutura e, para isso, são propostos métodos de gerência e índices de qualidade para ambos os casos.

Palavras-chave: Ferrovias; Gerência de vias; Índices de qualidade; Geometria ferroviária; Superestrutura ferroviária; Defeitos. 



\section{Abstract}

\section{ILDEFONSO, J. S. Proposal for a management system for Brazilian railways.}

2012. 171 p. Thesis (Ph.D.) - Engineering School of Sao Carlos, University of Sao Paulo, Sao Carlos, 2012.

The Brazilian railway system consists of a network of approximately 30,000 kilometers, which runs a fleet of more than 2,900 locomotives and 92,000 wagons, transporting approximately $23 \%$ of the load of the country, while in developed countries this mode accounts for about $40 \%$ of the cargo. The track maintenance accounts for $12 \%$ to $30 \%$ of the cost of operating and the cost was around $\$ 300$ million in 2000 at railroads in Brazil, showing that simple improvements in the way maintenance are performed, imply great savings for the industry. There are basically three types of maintenance that can be performed: corrective maintenance, preventive maintenance and predictive maintenance. Using the management of railways is possible to determine which is most appropriate maintenance and when to run it in order to use the available resources in the best way possible. The main goal of this research is to study the rail with respect to geometry and structural condition of the elements of the superstructure and to this are proposed methods for management and quality indexes for both cases.

Keywords: Railroad; Management system; Quality index; Geometry; Railway superstructure; Defects. 

Figura 2.1: Seção típica de via férrea $\quad 12$

Figura 2.2: Seção típica de trilho 14

Figura 2.3: Dormentes de madeira $\quad 17$

Figura 2.4: Dormente bi-bloco de concreto armado 19

Figura 2.5: Dormente monobloco de concreto protendido 19

Figura 2.6: Dormentes de aço 20

Figura 2.7: Dormentes de plástico $\quad 21$

Figura 2.8: Lastro $\quad 25$

Figura 2.9: Prego de linha $\quad 27$

Figura 2.10: Tirefond $\quad 27$

Figura 2.11: Tirefonadeira $\quad 27$

Figura 2.12: Retensores 28

Figura 2.13: Fixação elástica tipo GEO 29

Figura 2.14: Fixação elástica tipo grampo simples 29

Figura 2.15: Fixação elástica tipo grampo duplo 30

Figura 2.16: Fixação elástica tipo Pandrol 30

Figura 2.17: Fixação elástica tipo Deenik 31

Figura 2.18: Fixação elástica tipo RN 31

Figura 2.19: Talas de junção 32

Figura 2.20: Talas de junção - Tipos 32

Figura 2.21: Talas de junção - Furos 33

Figura 2.22: Parafuso para tala de junção 34

Figura 2.23: Arruelas para talas de junção 34

Figura 2.24: Placa de apoio 34

Figura 3.1: Defeitos de bitola 38

Figura 3.2: Trilho desnivelado 39

Figura 3.3: Empeno $\quad 40$

Figura 4.1: Árvore de decisão para o defeito trincas por fadiga 63

Figura 4.2: Escala dos índices de condição usada pelo RAILER 87

Figura 5.1: Malha Sul e trechos de estudo 94

Figura 5.2. Carro controle - frente 96

Figura 5.3. Carro controle - trás 96 
Figura 5.4: Dados de variação de bitola captados pelo carro controle

Figura 5.5. Curva normal padronizada 101

Figura 5.6: Distribuição da variação de bitola em 2008

Figura 5.7: Comportamento ao longo dos anos dos parâmetros geométricos avaliados 103

Figura 5.8: Condição da via em função do IQG 110

Figura 5.1: Curva de ponderação para lastro contaminado 131

Figura 5.2: Curva de ponderação para dormente em mau estado e severidade baixa 132

Figura 5.3: Curva de ponderação para dormente em mau estado e severidade média 132

Figura 5.4: Curva de ponderação para dormente em mau estado e severidade alta 133

Figura 5.5: Curva de ponderação para dormente em mau estado e severidade muito alta 133

Figura 5.6: Curva de ponderação para dormente mal posicionado e severidade baixa 134

Figura 5.7: Curva de ponderação para dormente mal posicionado e severidade média 134

Figura 5.8: Curva de ponderação para dormente mal posicionado e severidade alta 135

Figura 5.9: Curva de ponderação para dormente faltando 135

Figura 5.10: Curvas de ponderação para trilhos com 1, 2, 3 ou 4 tipos de defeitos e severidade baixa

Figura 5.11: Curvas de ponderação para trilhos com 1, 2, 3 ou 4 tipos de defeitos e severidade média

Figura 5.12: Curvas de ponderação para trilhos com 1, 2, 3 ou 4 tipos de defeitos e severidade alta

Figura 5.13: Curvas de ponderação para juntas com 1, 2 ou 3 tipos de defeitos e severidade baixa

Figura 5.14: Curvas de ponderação para juntas com 1, 2 ou 3 tipos de defeitos e severidade média

Figura 5.15: Curva de ponderação para juntas com 1 tipos de defeitos e severidade alta

Figura 5.16: Curva de ponderação para juntas com 1 tipos de defeitos e severidade muito alta

Figura 5.17: Curva de ponderação para fixação com 1 ou 2 tipos de defeitos e severidade alta

Figura 5.18: Curvas de correção para o grupo "Trilhos, Juntas e Acessórios"

Figura 5.19: Curvas de correção para o grupo "Dormentes"

Figura 5.20: Relação entre ICET e ACET

Figura 5.21: Relação entre ICED e ACED

Figura 5.22: Relação entre ICEL e ACEL 
Figura 5.23. Relação entre ICEG e ACEG considerando as curvas de ponderação propostas

Figura 5.24: Qualidade estrutural da via

Figura 5.25: Árvore de decisão para defeitos estruturais 

Tabela 2.1: Classificação dos trilhos $\quad 15$

Tabela 2.2: Dimensões dos trilhos $\quad 15$

Tabela 2.3: Dimensões dos dormentes de madeira 18

Tabela 2.4: Dimensões dos dormentes de aço 20

Tabela 2.5: Dimensões dos dormentes de plástico 22

Tabela 2.6: Dimensões das talas de junção 33

Tabela 4.1: Condição do pavimento em função do IGG 66

Tabela 4.2: Condição do pavimento em função do IES 67

Tabela 4.3: Condição do pavimento em função do ICP 70

Tabela 4.4: Definição da classe da ferrovia 73

Tabela 4.5: Classificação das ferrovias de acordo com a FRA 73

Tabela 4.6: Condição da via baseada no índice de irregularidade da Amtrak $\quad 74$

Tabela 4.7: Tolerâncias definidas pelo método da FRA 76

Tabela 4.8: Valores aceitáveis para diferenças de alinhamento pela FRA 76

Tabela 4.9: Tolerância em milímetros para desvios negativos de bitola 77

Tabela 4.10: Tolerância em milímetros para desvios positivos de bitola 77

Tabela 4.11: Tolerância em milímetros para o alinhamento 77

Tabela 4.12: Tolerância em milímetros para o perfil 77

Tabela 4.13: Tolerância em milímetros para torção 78

Tabela 4.14: Condição da via baseada nos valores de $w_{5} \quad 79$

Tabela 4.15: Tolerância em milímetros recomendada pela RISSB 79

Tabela 4.16: Valores de SD 80

Tabela 4.17: Condição da via baseada nos valores de TGI 80

Tabela 4.18: Valores permitidos do índice J em função da velocidade 81

Tabela 4.19: Valores máximos para empeno 82

Tabela 4.20: Valores máximos para nivelamento e alinhamento 83

Tabela 4.21: Categorias da escala dos índices de condição 89

Tabela 4.22: Descrição dos níveis de severidade 90

Tabela 5.1: Valores mínimos para coleta de dados 98

Tabela 5.2: Distribuição estatística dos trechos com defeito em $2008 \quad 98$

Tabela 5.3: Distribuição estatística dos trechos com defeito no ano de 2009

Tabela 5.4: Distribuição estatística dos trechos com defeito em $2010 \quad 99$ 
Tabela 5.5: Distribuição estatística dos trechos com defeito em 2011

Tabela 5.6: Distribuição estatística dos trechos com defeito em 2012

100

Tabela 5.7: Valores limites adotados

106

Tabela 5.8: Pesos atribuídos para cada defeito

106

Tabela 5.9: Valores aceitáveis propostos para vias novas

108

Tabela 5.10: Valores aceitáveis propostos com restrição de velocidade

108

Tabela 5.11: Valores de segurança propostos

109

Tabela 5.12: Valores limites usados no método

110

Tabela 5.13: Atividades de M\&R recomendadas

111

Tabela 5.14: Exemplo dos dados coletados

113

Tabela 5.15: Notas para lastro contaminado

Tabela 5.16: Notas para dormente mal conservado e severidade baixa

Tabela 5.17: Notas para dormente mal conservado e severidade média

Tabela 5.18: Notas para dormente mal conservado e severidade alta

Tabela 5.19: Notas para dormente mal conservado e severidade muito alta

122

Tabela 5.20: Notas para dormente mal posicionado e severidade baixa 122

Tabela 5.21: Notas para dormente mal posicionado e severidade média 122

Tabela 5.22: Notas para dormente mal posicionado e severidade alta 123

Tabela 5.23: Notas para dormente faltando 123

Tabela 5.24: Notas para trilhos com 1 tipo de defeito e severidade baixa 123

Tabela 5.25: Notas para trilhos com 2 tipos de defeitos e severidade baixa $\quad 124$

Tabela 5.26: Notas para trilhos com 3 tipos de defeitos e severidade baixa 124

Tabela 5.27: Notas para trilhos com 4 tipos de defeitos e severidade baixa $\quad 124$

Tabela 5.28: Notas para trilhos com 1 tipo de defeito e severidade média $\quad 125$

Tabela 5.29: Notas para trilhos com 2 tipos de defeitos e severidade média 125

Tabela 5.30: Notas para trilhos com 3 tipos de defeitos e severidade média $\quad 125$

Tabela 5.31: Notas para trilhos com 4 tipos de defeitos e severidade média 126

Tabela 5.32: Notas para trilhos com 1 tipo de defeito e severidade alta 126

Tabela 5.33: Notas para trilhos com 2 tipos de defeitos e severidade alta 126

Tabela 5.34: Notas para trilhos com 3 tipos de defeitos e severidade alta 127

Tabela 5.35: Notas para trilhos com 4 tipos de defeitos e severidade alta $\quad 127$

Tabela 5.36: Notas para ligação com 1 tipo de defeito e severidade baixa 127

Tabela 5.37: Notas para ligação com 2 tipos de defeitos e severidade baixa 128

Tabela 5.38: Notas para ligação com 3 tipos de defeitos e severidade baixa 128

Tabela 5.39: Notas para ligação com 1 tipo de defeito e severidade baixa 128

Tabela 5.40: Notas para ligação com 2 tipos de defeitos e severidade baixa 129

Tabela 5.41: Notas para ligação com 3 tipos de defeitos e severidade baixa $\quad 129$ 
Tabela 5.42: Notas para ligação com 1 tipos de defeitos e severidade alta

Tabela 5.43: Notas para ligação com 1 tipos de defeito e severidade muito alta

Tabela 5.44: Notas para fixação com 1 tipos de defeito e severidade alta

Tabela 5.45: Notas para fixação com 2 tipos de defeito e severidade alta

Tabela 5.46: Valores de ICET, ICED, ICEL e ACEG

Tabela 5.47: Atividades de M\&R recomendadas para a superestrutura

Tabela A1: Valores de ponderação

Tabela A2: Escalonamento dos valores de ponderação 165

Tabela A3. Valores Totais de Ponderação e Valores Corrigidos de Ponderação 



\section{Sumário}

\section{AGRADECIMENTOS}

RESUMO

ABSTRACT

LISTA DE FIGURAS

LISTA DE TABELAS

1 INTRODUCÃO

1.1 HISTÓRICO

1.1.1 Ferrovias no mundo

1.1.2 Mapa ferroviário em alguns países

1.1.3 Ferrovias no Brasil

1.2 JUSTIFICATIVA

1.3 OBJETIVOS

1.4 ORGANIZAÇÃO DA TESE

2 VIA PERMANENTE

2.1 CONCEITOS INICIAIS

2.2 COMPONENTES DA SUPERESTRUTURA

2.2.1 Trilho

2.2.2 Dormente

2.2.2.1 Dormentes de madeira

2.2.2.2 Dormentes de concreto

2.2.2.3 Dormentes de aço

2.2.2.4 Dormentes de plástico

2.2.2.5 Comparação entre os diferentes materiais usados em dormentes 22

2.2.3 Lastro

2.2.4 Acessórios de trilho

2.2.4.1 Acessórios de fixação 26

2.2.4.2 Acessórios de ligação 31

2.2.4.3 Placas de apoio $\quad 34$

\section{DEFEITOS NA SUPERESTRUTURA DA VIA}

3.1 DEFEITOS

3.1.1 Defeitos geométricos

3.1.1.1 Defeitos de bitola

3.1.1.2 Defeitos de nivelamento 
3.1.1.3 Defeitos no alinhamento 40

3.1.1.4 Empeno 40

3.2 DEFEITOS ESTRUTURAIS 41

3.2.1 Defeitos nos trilhos 41

3.2.2 Defeitos nas juntas 44

3.2.3 Defeitos nos acessórios de fixação 46

$\begin{array}{ll}3.2 .4 \text { Defeitos nas placas de apoio } & 47\end{array}$

3.2.5 Defeitos nos dormentes 48

3.2.5.1 Dormentes isolados 48

3.2.5.2 Dormentes faltando 49

3.2.5.3 Dormentes mal posicionados 50

3.2.5.4 Grupos de dormentes 51

3.2.5 Defeitos no lastro 53

3.3 EQUIPAMENTOS PARA MANUTENÇÃO 53

3.3.1 Equipamentos leves $\quad 54$

3.3.2 Equipamentos especiais 55

4 SISTEMAS DE GERÊNCIA

4.1 AVALIAÇÕES DE PAVIMENTOS

4.2 NÍVEIS ADMINISTRATIVOS

4.2.1 Gerência em nível de rede 59

4.2.2 Gerência em nível de projeto 59

4.3 IMPLEMENTAÇÃO DE SISTEMAS DE GERÊNCIA

4.4 ATIVIDADES DE MANUTENÇÃO E REABILITAÇÃO 61

4.5 MÉTODOS PARA AVALIAÇÃ̃O DA CONDIÇÃO DO PAVIMENTO 65

4.6 SISTEMAS DE GERÊNCIA DE VIAS FÉRREAS

4.6.1 Análise geométrica $\quad 72$

4.6.1.1 Conceito $\quad 72$

4.6.1.2 Classificações das ferrovias $\quad 72$

4.6.1.3 Índices e limites geométricos no mundo 74

4.6.2 O RAILER e a análise estrutural 83

4.6.2.1 Conceito 83

4.6.2.2 Inspeções 84

4.6.2.3 Inventário da malha 85

4.6.2.4 Atividades de pré-inspeção 85

4.6.2.5 Índices de condição 86

5 MÉTODOS E ÍNDICES PROPOSTOS $\quad 93$

5.1 FERROVIAS EM ESTUDO 93

5.1.1 Superestrutura 94

5.1.2 Características do tráfego 95

5.1.3 Manutenções no trecho 96

5.2 MODELO GEOMÉTRICO 96

5.2.1 Coleta de dados 96

5.2.2 Análise dos dados 98

5.2.3 Composição dos índices geométricos 103

5.3 MODELOS ESTRUTURAIS $\quad 111$ 
5.3.1 Caracterização do método 112

5.3.2 Levantamentos de dados 112

5.3.3 Tipos de defeitos $\quad 114$

5.3.3.1 Grupo de lastro 114

$\begin{array}{ll}\text { 5.3.3.2 Grupo de dormente } & 114\end{array}$

5.3.3.3 Grupo trilho, juntas e acessórios $\quad 114$

$\begin{array}{ll}\text { 5.3.4 Níveis de severidade } & 115\end{array}$

5.3.5 Avaliações subjetivas $\quad 118$

5.3.6 Densidade 119

$\begin{array}{ll}\text { 5.3.7 Curvas de ponderação } & 119\end{array}$

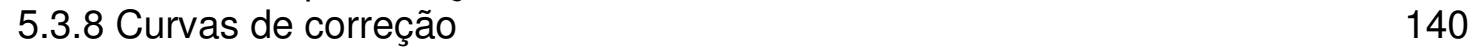

5.3.9 Proposição de índices estruturais individuais e global 142

6 CONCLUSÕES E SUGESTÕES 151

$\begin{array}{ll}\text { REFERÊNCIAS } & 155\end{array}$

ANEXO A - PROCEDIMENTO PARA DETERMINAÇÃO DO VALOR DE PONDERAÇÃO CORRIGIDO E DOS ÍNDICES ESTRUTURAIS 161

APÊNDICE - TERMO DE CONFIDENCIALIDADE 167 

Não diga que a vitória está perdida

Se é de batalhas que se vive a vida

(RaulSeixas)

NTRODUC̣ÃO

As ferrovias brasileiras são responsáveis pelo transporte de aproximadamente 165 milhões de toneladas úteis de carga anualmente - o que representa pouco mais de um quinto da movimentação de cargas no país - por sobre uma malha férrea composta por quase 30 mil quilômetros entre trechos concedidos e não concedidos e que é percorrida por mais de 2,9 mil locomotivas e 92 mil vagões (CNT, 2012).

O escoamento da produção primária no Brasil, especialmente grãos e minérios, necessita ser feito sem interrupções e com segurança, para que os lucros sejam maximizados. As ferrovias devem ser responsáveis por dar esse caráter de permanência no transporte de cargas, embora não é o que ocorra no país; pelo contrário, a atual distribuição da malha férrea nacional se mostra um gargalo na vazão da produção nacional, quer por sua extensão, pela diferença entre as bitolas usadas ou mesmo pelas práticas de manutenção e reabilitação executadas sem critérios técnicos adequados. 
Outros problemas encontrados em nossa malha ferroviária refletem a falta de planejamento não só no setor de transportes, mas na infraestrutura urbana nacional como um todo, por exemplo, invasões na faixa de domínio, elevado número de passagens em nível (mais de $12 \mathrm{mil}$ ) e a falta de contorno em áreas urbanas. Tudo isso faz com que a velocidade média seja de $25 \mathrm{~km} / \mathrm{h}$, valor extremamente baixo, principalmente se confrontada à velocidade média em países desenvolvidos, como nos Estados Unidos, que é de $80 \mathrm{~km} / \mathrm{h}$.

Tendo em vista que o principal objetivo de um sistema de transportes é movimentar cargas e pessoas da forma mais segura e confortável possível, sempre buscando economia e desenvolvimento, deve-se procurar diminuir ao máximo o número de acidentes e interrupções do tráfego nas linhas férreas.

As concessões de quase a totalidade da malha ferroviária brasileira trouxeram melhorias na qualidade da via, assim como foram responsáveis pelo aumento na quantidade de toneladas úteis transportadas e respectiva relação com o produto interno bruto (p. ex., a quantidade de cargas movimentadas nas ferrovias brasileiras aumentou em $80 \%$ desde 1996). Embora estas melhorias pareçam significativas, o Brasil ainda está distante do que se possa considerar o ideal para um país que se encontra em pleno desenvolvimento, em especial se comparado aos países desenvolvidos, nos quais o transporte de carga por ferrovias ocupa em torno de $40 \%$ da matriz de transportes. Contratos de concessão mais bem elaborados e efetiva fiscalização pelos órgãos responsáveis poderia garantir oferta melhor do serviço de transporte, sobretudo com diminuição no número de interrupções no tráfego de trens.

Para que a quantidade de acidentes e interrupções no tráfego de trens seja minimizada, deve-se levar em conta que a deterioração da superestrutura ferroviária ao longo do tempo é esperada, seja ela pela ação do tráfego ou das intempéries, porém é necessário que as ações de intervenção sejam planejadas de forma adequada para que a ferrovia apresente bom desempenho e serventia ao menor custo possível, sobretudo em países com carência de recursos e investimentos. 
Um sistema de gerência de pavimentos adequado às ferrovias pode direcionar de forma satisfatória os escassos recursos disponíveis para manutenção e reabilitação da malha férrea, ou parte dela, lançando mão de critérios de priorização e adequação técnica, otimizando, assim, o resultado final.

Um banco de dados completo da malha ferroviária é imprescindível para que o sistema de gerência funcione da forma desejada. Para isso, se faz necessário o levantamento inicial de dados - dados de inventário - que incluem, por exemplo, a definição dos trechos a serem analisados. Com a análise dos dados de inventário é possível determinar o tipo de levantamento de dados a ser executado e o dimensionamento da(s) equipe(s), máquina(s) e equipamento(s) necessários.

Há basicamente três tipos de manutenção passíveis de serem executadas: manutenção corretiva, que é a intervenção não programada, guiada pelo ciclo "quebra-repara"; manutenção preventiva, que é a troca ou reparo regular dos materiais e equipamentos críticos; manutenção preditiva, que é aquela que utiliza de modelos probabilísticos ou estocásticos para predizer o tempo, quilometragem ou número de ciclos corretos para que seja feita uma determinada intervenção.

Com o uso da gerência de vias férreas é possível determinar qual manutenção é a mais apropriada e quando se deve executá-la, de forma a utilizar os recursos financeiros disponíveis da melhor forma possível. Para isso, pode-se fazer uso de índices que representem tanto a qualidade da via no momento da análise, quanto desempenho dessa via, ou seja, a serventia que a via apresenta ao longo do tempo e/ou a evolução dos defeitos que a afetam.

\subsection{HISTÓRICO}

O desenvolvimento de um país está diretamente ligado à sua capacidade e qualidade na movimentação de cargas e pessoas ao longo de seu território. Não 
obstante estão as ferrovias, como importante via de ligação e condutora de desenvolvimento, desde os primórdios de sua concepção.

Para o entendimento de como se chegou às ferrovias atuais, vale apresentar não somente um breve histórico sobre sua evolução, mas também o panorama mundial contemporâneo, uma vez que a gerência de vias férreas - com exceção do "quebrarepara" - é, de certo modo, recente.

\subsubsection{Ferrovias no mundo}

Na segunda metade do século XVIII já eram utilizadas guias para a condução de vagonetas no interior das minas de carvão na Inglaterra. No início essas guias eram construídas em madeira e posteriormente foram substituídas por ferro.

Em 1803, após dois anos de construção, foi inaugurada na Inglaterra a Surrey Iron Railway, a primeira ferrovia destinada ao transporte de carga - com tração animal -, ligando Wandesworth a Croyden.

A busca por meios de transporte que agilizassem a movimentação de cargas em prol de lucros mais elevados, aliada à invenção da máquina a vapor, fez com que, em 1804, fosse inventada por Richard Thevithick a primeira locomotiva a vapor realmente funcional que rodasse sobre trilhos, a Pennydarren. Essa locomotiva foi capaz de puxar 5 vagões com 10 toneladas e 70 passageiros à velocidade de $5 \mathrm{~km} / \mathrm{h}$ em um trecho teste.

A primeira ferrovia destinada ao transporte de passageiros foi inaugurada em $1807 \mathrm{e}$ recebeu o nome Oystermouth Railway. Nesta ferrovia o transporte ainda era feito por meio de tração animal.

Dez anos se passaram até George Stephenson dar um grande passo no setor ferroviário, apresentando ao mundo a locomotiva Blucher, com uma importante mudança, o uso de rodas com frisos, que a impediam de descarrilar. 
Stephenson construiu, em 1825, a locomotiva Locomotion, que transportou, em sua primeira viagem, 80 toneladas de carvão entre as cidades de Stockton e Darlington; um percurso de $15 \mathrm{~km}$ percorrido a velocidade de $20 \mathrm{~km} / \mathrm{h}$. O sucesso da Locomotion levou à fundação da primeira fábrica de locomotivas do mundo.

As ferrovias rapidamente se tornaram essenciais à movimentação de bens e pessoas na Inglaterra e sua expansão ocorreu de forma acelerada, passando de cerca de $40 \mathrm{~km}$, no ano de 1825, para aproximadamente $6.600 \mathrm{~km}$ em 1850, ano em que chegaram aos arredores de Londres, porém sem poder adentrar a cidade, uma vez que não foi permitida a derrubada de casas; para solucionar esse problema foi construída a Metropolitan Railway sob o solo, dando origem ao Metrô.

\section{Mapa ferroviário em alguns países}

O pico do comprimento da malha ferroviária inglesa se deu por volta de 1930, quando contava com aproximadamente $32.500 \mathrm{~km}$ de vias férreas. A partir desse ano a malha férrea foi diminuindo e hoje tem cerca de $15.800 \mathrm{~km}$ (DFT, 2012).

O Canadá tem a ferrovia como principal modo de transporte de cargas, respondendo por $70 \%$ do total; em suas ferrovias também são transportados 70 milhões de passageiros por ano. Embora cerca de $2.000 \mathrm{~km}$ tenham sido desativados nos últimos 10 anos, o país ainda conta com aproximadamente $44.500 \mathrm{~km}$ de vias férreas (RAC, 2012).

A inauguração da primeira ferrovia indiana data de 1853, a qual ligava Bombay a Thane em um percurso de $34 \mathrm{~km}$. Hoje, com malha férrea perto de $110.000 \mathrm{~km}$, a Índia está entre os países com a malha férrea mais extensa do mundo (IR, 2012).

A China contava com $80.000 \mathrm{~km}$ de ferrovias no final de 2008 (MR, 2012) e em um ano passou a $86.000 \mathrm{~km}$ (CIA, 2012). A previsão é que o país gaste $€ 433$ bilhões até 2014 na ampliação do sistema (ANPTRILHOS, 2012). 
O Departamento de Estradas de Ferro da Rússia, criado em 1842, foi quem supervisionou a construção da primeira ferrovia russa, que ligava São Petersburgo à Moscou. Já no ano de 1900 a Rússia contava com 44.900 km de ferrovias e no início da Primeira Guerra Mundial, a malha ferroviária russa tinha comprimento de 58.500 $\mathrm{km}$, por onde eram transportados 132.000 toneladas de carga e 185.000 passageiros por ano. O sistema férreo russo sofreu com a Primeira Guerra Mundial e a Guerra Civil, perdendo mais de $60 \%$ de sua malha, embora recuperada posteriormente ao longo dos anos. Hoje a Rússia conta com mais de $87.000 \mathrm{~km}$ de vias férreas, sendo a segunda malha do mundo em extensão (RR, 2012).

A Argentina é o país que possui atualmente malha férrea mais extensa da América do Sul, com cerca de $34.000 \mathrm{~km}$ de vias. A primeira linha férrea argentina foi inaugurada em 1857 com a finalidade de escoar a produção agrícola. Hoje significativa parte da malha encontra-se privatizada na forma de concessão.

\subsubsection{Ferrovias no Brasil}

No ano de 1828 foi dado início à mobilização pela implantação de ferrovias no Brasil, com a autorização do Governo Imperial para a construção e exploração de estradas, através da lei José Clemente.

Em 1835, durante a regência do Segundo Reinado, o então regente Diogo Antônio Feijó, tentou, sem sucesso, implantar a primeira ferrovia no Brasil, concedendo incentivos a quem construísse uma ferrovia que ligasse o Rio de Janeiro à São Paulo, Rio Grande do Sul, Minas Gerais e Bahia.

A primeira ferrovia do Brasil foi inaugurada em 1854 e ligava o porto de Mauá, na Baía de Guanabara, à raiz da Serra da Estrela, em Petrópolis, num percurso de $14,5 \mathrm{~km}$. Foi idealizada e construída por Irineu Evangelista de Sousa, na época Barão de Mauá. A primeira viagem foi feita pela locomotiva Baroneza - nome dado em homenagem à esposa do Barão -, em um tempo de 23 minutos. 
Em 1858, nomeada Estrada de Ferro D. Pedro II, foi inaugurada a segunda ferrovia brasileira, a qual, em 1889, quando da Proclamação da República, viria a se tornar Estrada de Ferro Central do Brasil, uma das mais importantes do nosso país.

Em 1877 foi concluída a junção das ferrovias D. Pedro II e Paulista, permitindo a ligação entre Rio de Janeiro e São Paulo.

A construção ferroviária no Brasil teve seu grande momento entre 1911 e 1916 . Até então havia cerca de $10 \mathrm{mil} \mathrm{km}$ de ferrovias e nesse período foram construídos mais 5 mil km.

Em 1957 foi criada a Rede Ferroviária Federal (RFFSA), vinculada ao Ministério dos Transportes, com a consolidação de 18 ferrovias regionais. Em 1996, época de início de sua desestatização, a RFFSA contava com $22.000 \mathrm{~km}$ de vias (RFFSA, 2011).

Em 1971 foi oficializada a Ferrovia Paulista S.A. (FEPASA), com a união de cinco ferrovias: Paulista, Sorocabana, Mogiana, Araraquarense e São Paulo - Minas.

Em 1985 foi concluída a construção da Estrada de Ferro Carajás, que liga a Serra dos Carajás ao porto de Itaqui, no Maranhão.

De 1996 a 1998 ocorreram as privatizações das ferrovias brasileiras.

Atualmente o Brasil conta com aproximadamente $30 \mathrm{mil} \mathrm{km}$ de ferrovias, entretanto o plano do Governo Federal é construir mais 20 mil km até o ano de 2025 por meio do Plano Nacional de Logística de Transportes (PNLT), em um orçamento estimado em mais de 150 bilhões de reais. Com isso o setor ferroviário irá representar $35 \%$ da matriz nacional de transportes (PNLT, 2009). 


\subsection{JUSTIFICATIVA}

É de consenso de vários autores que a manutenção de via permanente responde por $12 \%$ a $30 \%$ do custo de operação de uma via férrea, dependendo do uso a que se destina e de sua importância. Nas ferrovias brasileiras, esse gasto ficou em torno de 300 milhões de dólares no ano de 2000, evidenciando que simples melhorias no modo como as manutenções são realizadas implicariam em grande economia para o setor (RODRIGUES, 2001).

Os Estados Unidos gastam, em média, 20 milhões de dólares anualmente com avaliação da condição de sua malha férrea e, mesmo assim, têm perdas da ordem de 50 milhões de dólares anuais devido a descarrilamentos por defeitos na via (LI et al., 2001). Por isso, melhoras no sistema de gerência de ferrovias e as consequentes adequações nas manutenções, levam a economias significativas, além de permitir o escoamento de produtos e insumos mais rapidamente e o transporte de pessoas de maneira mais confortável e segura.

\subsection{OBJETIVOS}

O objetivo principal desta pesquisa é a proposição de um sistema de gerência voltado às ferrovias brasileiras.

São objetivos deste trabalho, também:

- Estabelecer os parâmetros mais importantes para análise de ferrovias;

- Estabelecer um procedimento para determinação dos níveis de qualidade geométrica;

- Estabelecer um procedimento para determinação dos níveis de qualidade estrutural;

- Conceber índices que permitam a análise da qualidade e da degradação ao longo do tempo; 
- Indicar as manutenções e reabilitações adequadas de acordo com a qualidade da via.

\subsection{ORGANIZAÇÃO DA TESE}

Este trabalho está dividido em 6 capítulos. Sequencialmente, no Capítulo 2, é apresentada a via férrea como estrutura em todos os seus componentes.

No Capítulo 3 são descritos os defeitos que a via está sujeita, os equipamentos usados para avaliação e equipamentos usados para manutenção e reabilitação da via férrea, além dos tratamentos usuais.

No Capítulo 4 são apresentados conceitos quanto à composição de sistemas gerência de pavimentos e seu uso em ferrovias.

O Capítulo 5 é destinado ao estudo geométrico e estrutural da via férrea com ênfase na realidade brasileira, foco principal desta pesquisa. Neste capítulo são propostos métodos de avaliação da via férrea e, também, índices que qualifiquem as ferrovias em função tanto da condição geométrica, quanto estrutural, o que permite analisar o estado atual da via e sua degradação ao longo do tempo.

Por fim, no Capítulo 6, são apresentadas as conclusões da pesquisa e sugestões para trabalhos futuros. 

O conhecimento é o processo de acumular dados

\subsection{CONCEITOS INICIAIS}

A via permanente pode ser entendida como o conjunto que forma a superestrutura de uma via férrea e que está sujeito ao desgaste pelas intempéries e pelo contato com as rodas dos veículos (BRINA, 1979). A nomenclatura via permanente remonta ao início das ferrovias e deve-se ao fato das vias férreas terem propiciado um caráter de permanência às estradas, que antes sofriam com condições adversas, como umidade e congelamento.

O estudo da via permanente, na forma de um sistema estrutural constituído de camadas finitas e assente sobre uma camada semi-infinita, o subleito, permite que seja feito um paralelo com os pavimentos rodoviários, tanto no estudo tensões e deformações, como propõe alguns pesquisadores (MEDINA, 1997; SILVA, 2002), 
como também no desempenho, ou serventia, o que leva ao encontro dos estudos direcionados à gerência de pavimentos.

A composição de um sistema de gerência passa pelo conhecimento dos materiais que compõem os pavimentos, sejam eles rodoviários ou ferroviários. Esse capítulo se destina a apresentar os materiais comumente encontrados na composição da via férrea.

\subsection{COMPONENTES DA SUPERESTRUTURA}

A superestrutura da via férrea é composta por trilhos, dormentes, lastro e acessórios. Consideram-se os demais elementos da via férrea como sendo parte da infraestrutura, que são o subleito e as obras de terraplanagem, os elementos de drenagem e as obras de arte especiais (p. ex. pontes, viadutos etc.). A Figura 2.1 mostra uma seção típica de ferrovia.

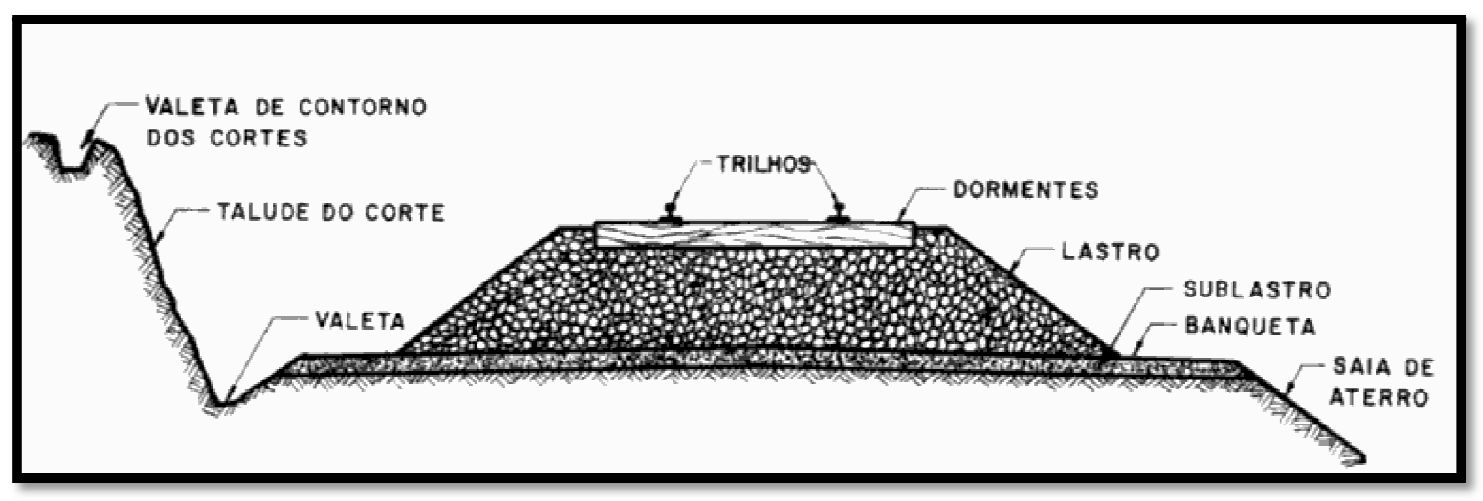

Figura 2.1: Seção típica de via férrea (BRINA, 1979).

No começo das construções de ferrovias, assim como de rodovias, não era dada a devida importância aos materiais sobre os quais era construída a via. Somente na metade do século XX, com o estudo do que hoje é conhecido como mecânica dos pavimentos, realizado por pesquisadores como J. Einsenmann, Talbot, Schram, Lomas, Timoshenko e R. Soneville é que a necessária seriedade foi despendida com o assunto. 
Atualmente busca-se implantar o conceito de pavimento ferroviário, visando dividir o sistema estrutural em camadas que possam ser estudadas à luz dos conhecimentos de mecânica dos pavimentos (MEDINA e MOTTA, 2006), a qual engloba a compreensão sobre os modelos constitutivos dos materiais componentes da via férrea.

\subsubsection{Trilho}

O trilho é o elemento da superestrutura que constitui a superfície de rolamento para as rodas dos veículos ferroviários e tem a função de transmitir os esforços aos dormentes (DNIT, 2011).

O modelo comumente usado nos dias de hoje segue o padrão Vignole (Figura 2.2) nome dado como referência ao engenheiro inglês que o idealizou - e é composto basicamente por três partes:

i. Boleto: parte superior do trilho, na qual se apoiam e são guiadas as rodas dos veículos;

ii. Alma: parte estreita e vertical do trilho, entre o boleto e o patim;

iii. Patim: parte inferior do trilho, mais larga, que se assenta no dormente direta ou indiretamente.

Anteriormente a esse formato de trilho, era largamente usado o trilho de duplo boleto, que possui dois boletos ligados à cada extremidade da alma. Um dos boletos, exercendo a função que hoje cabe ao patim, se apoia em uma peça especial, denominada panela, na qual o trilho é fixado com o uso de cunha. 


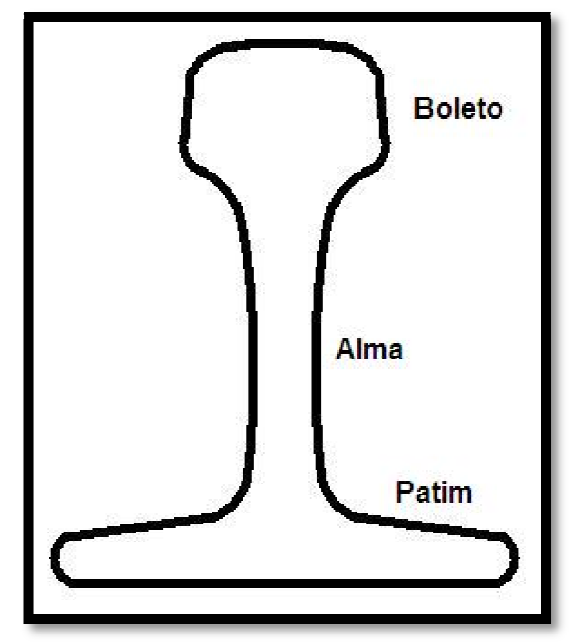

Figura 2.2: Seção típica de trilho.

O trilho Vignole pode ser fabricado de forma a ficar mais leve, sendo normalmente empregado em vias férreas para vagonetas; este modelo recebe o nome de Decauville.

O tipo de esforços que o trilho está destinado a receber faz com que ele trabalhe semelhantemente a uma viga. Tendo em vista isso, seu formato atual, um duplo T, permite que ele resista satisfatoriamente bem e com economia.

Encontram-se trilhos, no formato comercial, com comprimento de 12, 18 ou 24 metros e podem ser classificados em função do peso por unidade de metro, segundo o padrão da Companhia Siderúrgica Nacional - CSN (Tabela 2.1), que segue a norma ABNT NBR 7590:1991. 
Tabela 2.1: Classificação dos trilhos.

\begin{tabular}{c|c|c}
\hline Tipo & $\begin{array}{c}\text { Equivalente } \\
\text { americano }\end{array}$ & $\begin{array}{c}\text { Peso } \\
\mathbf{( k g f / m})\end{array}$ \\
\hline TR-25 & ASCE 5040 & 24,65 \\
TR-32 & ASCE 6540 & 32,05 \\
TR-37 & ASCE 7540 & 37,11 \\
TR-45 & ASCE 9020 & 44,64 \\
TR-50 & ASCE 10025 & 50,35 \\
TR-57 & ASCE 11525 & 56,90 \\
TR-68 & 135 RE & 67,56 \\
\hline
\end{tabular}

As dimensões dos trilhos variam de acordo com o tipo, como mostra a Tabela 2.2.

Tabela 2.2: Dimensões dos trilhos.

\begin{tabular}{|c|c|c|c|c|c|}
\hline FORMATO PADRÃO & Tipo & $\mathrm{A}(\mathrm{mm})$ & $B(\mathrm{~mm})$ & $C(\mathrm{~mm})$ & $\mathrm{D}(\mathrm{mm})$ \\
\hline C & TR-25 & 98,4 & 98,4 & 54,0 & 11,1 \\
\hline & TR-32 & 112,7 & 112,7 & 61,1 & 12,7 \\
\hline & TR-37 & 122,2 & 122,2 & 62,7 & 13,5 \\
\hline H & TR-45 & 142,9 & 130,2 & 65,1 & 14,3 \\
\hline & TR-50 & 152,4 & 136,5 & 68,2 & 14,3 \\
\hline$\neq$ & TR-57 & 168,3 & 139,7 & 69,0 & 15,9 \\
\hline $\mathrm{E}$ & TR-68 & 185,7 & 152,4 & 74,6 & 17,4 \\
\hline
\end{tabular}

\subsubsection{Dormente}

Dormente é a peça na qual os trilhos são apoiados e fixados e que transmite ao lastro parte dos esforços e vibrações produzidos pelos veículos ferroviários.

As dimensões do dormente e a taxa de dormentação - quantidade de dormentes por quilômetro - devem ser adequadamente escolhidas, de modo que os esforços 
transmitidos ao lastro não ultrapassem a sua capacidade resistiva. O controle das dimensões também tem o intuito de propiciar adequada rigidez, sem comprometer a elasticidade. Há padronização nas dimensões para os dormentes comuns de acordo com a bitola e o material utilizado; entretanto, existem dormentes especiais, com dimensões diferenciadas, empregados de acordo com a necessidade em aparelhos de mudança de via, pontes/viadutos, junta apoiada e trechos com terceiro trilho.

É de responsabilidade do dormente se opor aos esforços transversais e longitudinais da via, não deixando que a geometria da via se altere, bem como permitir a facilidade de nivelamento do lastro.

O dormente também tem como função, manter o espaçamento entre os trilhos paralelos invariável. A esse espaçamento é dado o nome de bitola, que pode ser definida mais especificamente como sendo a distância entre as faces internas dos boletos dos trilhos, tomada na linha normal a essas faces, a $16 \mathrm{~mm}$ abaixo do plano constituído pela superfície superior dos boletos.

Há vários materiais usados na fabricação de dormentes; dentre eles podem ser destacados a madeira, o concreto, o aço e o plástico. A escolha do tipo de material deve levar em conta resistência mecânica, resistência ao desgaste, facilidade de obtenção e economia.

\subsubsection{Dormentes de madeira}

O dormente de madeira (Figura 2.3) é o mais comum e o mais utilizado ainda hoje, embora a busca por novos materiais venha crescendo nos últimos anos, devido ao interesse em preservação ambiental e à escassez de madeira por proteção ao desmatamento de árvores nativas e o reflorestamento ineficiente. 

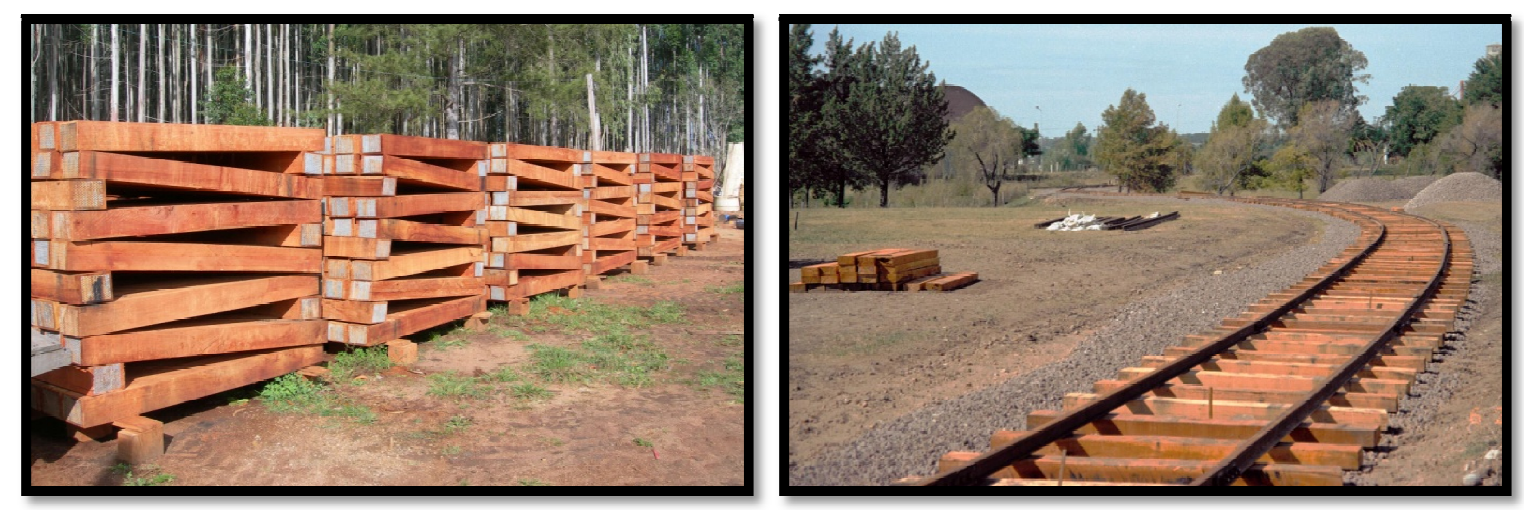

Figura 2.3: Dormentes de madeira.

Os dormentes de madeira são classificados quanto à forma em:

i. Roliço: dormente utilizado na sua forma mais natural, com cortes horizontais feitos apenas nos pontos de pregação. As costaneiras ficam integrais na madeira;

ii. Semi-roliço: dormente que apresenta apenas a parte superior serrada, onde se fixarão os grampos;

iii. Duas faces: dormente que apresenta duas faces serradas e duas faces abauladas. As faces serradas ficam nas partes superior e inferior do leito da ferrovia e servem para apoio e fixação dos pregos;

iv. Prismático: dormente em que as quatro faces são serradas e a peça é esquadrinhada. É a forma mais aprimorada de dormente.

A durabilidade dos dormentes de madeira está condicionada a fatores como espécie, qualidade e tratamento da madeira, clima, drenagem da via, característica do tráfego, acessórios de apoio e fixação, tipo de lastro e manutenção adequada.

Via de regra, os dormentes de madeira recebem tratamento antes do uso, com o intuito de protegê-los contra a ação de fungos, bactérias e insetos. Esse tratamento normalmente é feito com a impregnação de creosoto, sob pressão, em uma autoclave. 
A ABNT NBR 7511:2005 estabelece valores para as dimensões dos dormentes, de acordo com a bitola (Tabela 2.3).

Tabela 2.3: Dimensões dos dormentes de madeira.

\begin{tabular}{c|c|c|c}
\hline Bitola & Comprimento (cm) & Largura (cm) & Altura (cm) \\
\hline Estreita $(1,00 \mathrm{~m})$ & 200 & 22 & 16 \\
Larga $(1,60 \mathrm{~m})$ & 280 & 24 & 17 \\
\hline
\end{tabular}

\subsubsection{Dormentes de concreto}

Os primeiros dormentes de concreto foram inicialmente produzidos no final do século XIX, embora fossem muito pouco usados até a década de 1940, época em que começou a escassez de madeira, sobretudo na Europa, devido à $2^{\text {a }}$ Guerra Mundial.

No início, os dormentes de concreto eram afetados por muitas trincas e fissuras, especialmente no meio da peça, devido principalmente à vibração gerada pelo tráfego e ao apoio irregular sobre o lastro, uma vez que submetido às altas cargas, o momento fletor é extremamente elevado.

Nos últimos 60 anos houve considerável progresso na fabricação de dormentes de concreto em consequência de inúmeras pesquisas realizadas, tornando-o uma opção atrativa em muitos casos. Depois de todos esses anos de pesquisas e de diversos modelos estudados, apenas dois tipos se mostraram econômica e tecnicamente viáveis, sendo eles os dormentes bi-bloco de concreto armado e o monobloco de concreto protendido, cada um com vantagens peculiares que os direciona para determinado uso.

i. Dormente bi-bloco de concreto armado: consiste basicamente de dois blocos de concreto armado interligados por um perfil metálico (Figura 2.4). Este desenho permite que os dormentes sejam mais leves, com apoio sobre o 
lastro mais bem definido e elimina os riscos de fratura no centro do dormente, por flexão negativa e perda de estabilidade, resultante do apoio da parte central do dormente sobre o lastro. Outro ponto vantajoso é que, nessa forma, os dormentes apresentam o dobro da área de apoio lateral.
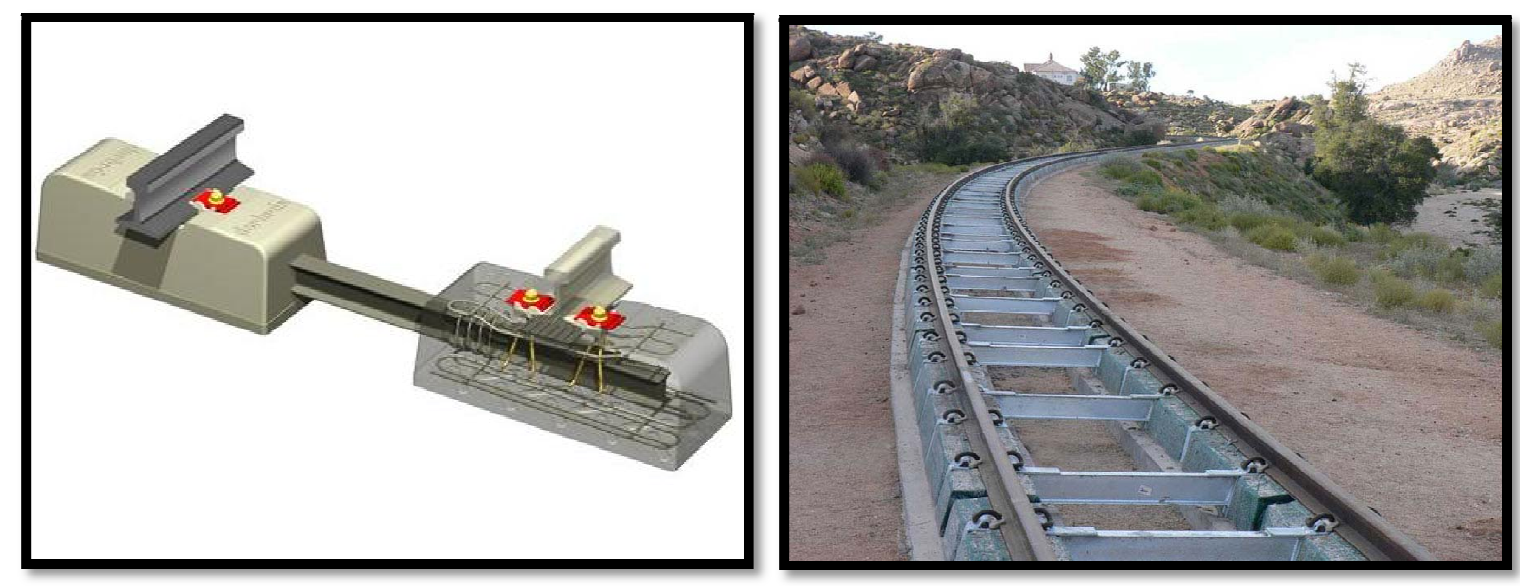

Figura 2.4: Dormente bi-bloco de concreto armado.

ii. Dormente monobloco de concreto protendido: consistem basicamente de uma viga monolítica de concreto protendido (Figura 2.5). Este tipo de desenho apresenta elevada estabilidade devido ao peso próprio, permite o uso em bitolas mistas e aparelhos de mudança de via.
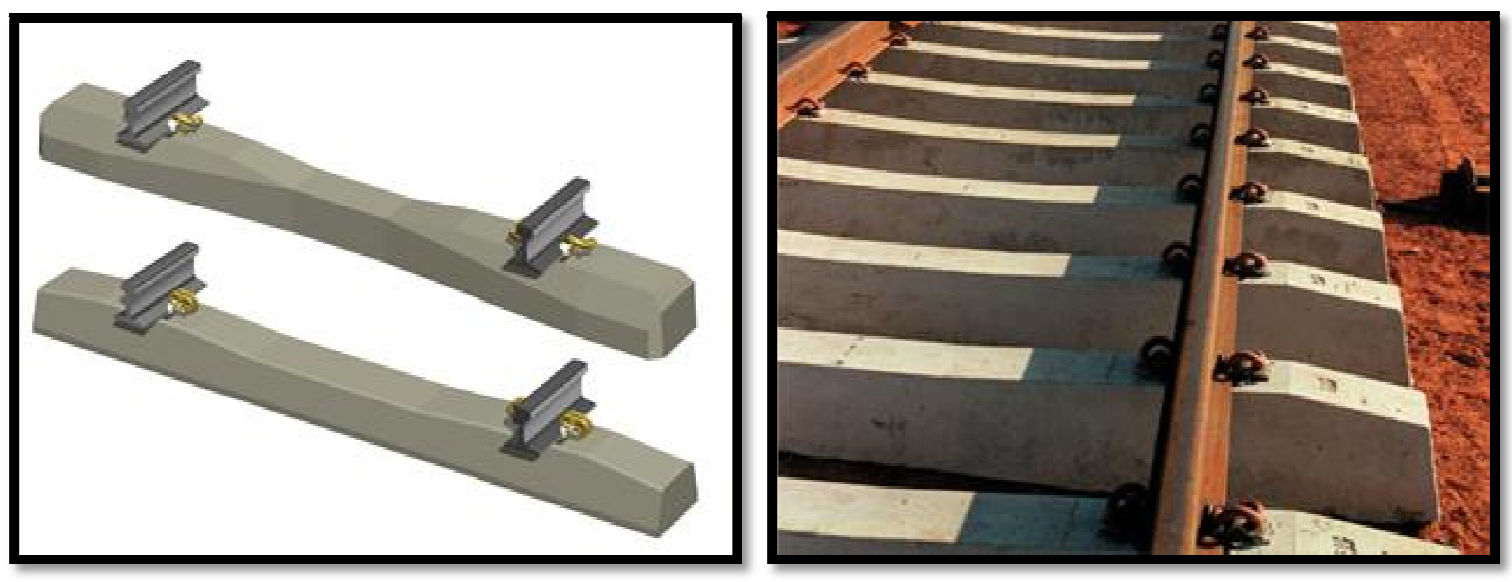

Figura 2.5: Dormente monobloco de concreto protendido. 


\subsubsection{Dormentes de aço}

Os dormentes de aço (Figura 2.6) começaram a ser fabricados na Alemanha, no ano de 1891. Com o início da 2a Grande Guerra Mundial, a produção de aço foi destinada para fins bélicos, fazendo com que a fabricação de dormentes desse material praticamente parasse, voltando a serem usados somente alguns anos após o final da guerra.
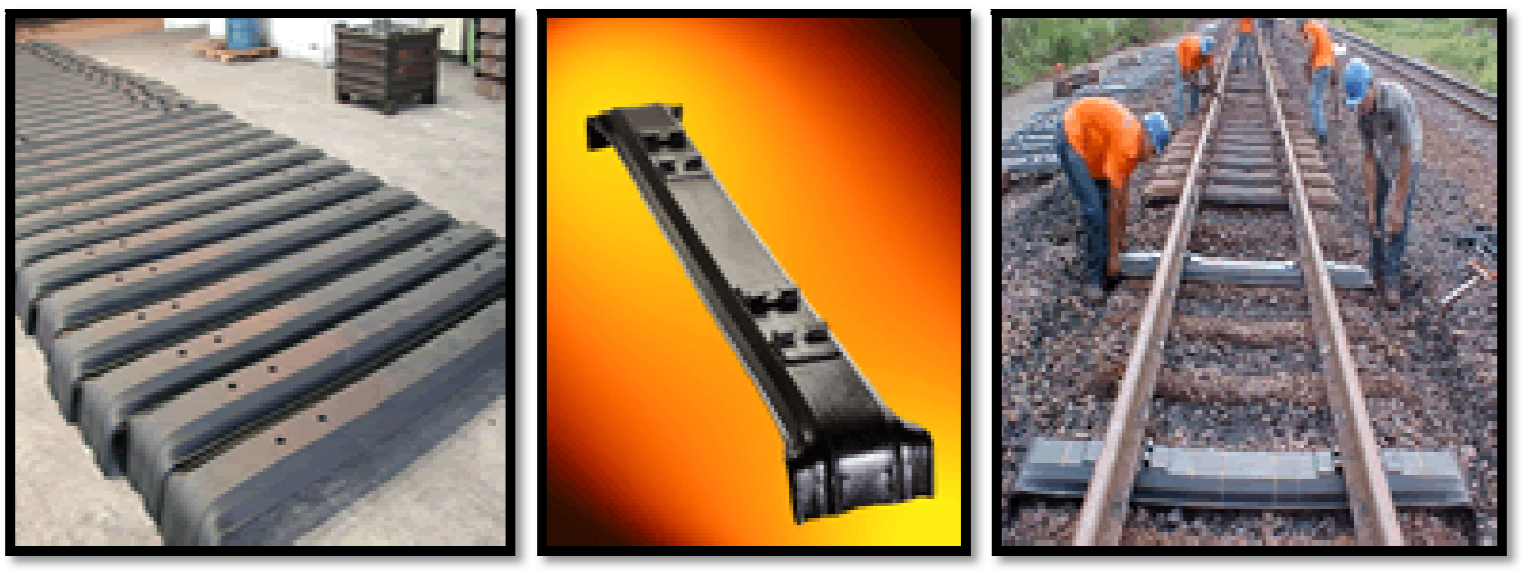

Figura 2.6: Dormentes de aço.

O dormente de aço consiste basicamente de uma chapa de aço laminada de 10 ou $12 \mathrm{~mm}$, em formato de $U$ invertido, com curvas nas extremidades para melhor fixação no lastro. A Tabela 2.4 apresenta as dimensões dos dormentes de aço.

Tabela 2.4: Dimensões dos dormentes de aço.

\begin{tabular}{c|c|c|c}
\hline Bitola & Comprimento $(\mathbf{c m})$ & Largura (cm) & Altura (cm) \\
\hline Estreita $(1,00 \mathrm{~m})$ & 220 & 26 & 9 \\
Padrão $(1,435 \mathrm{~m})$ & 270 & 26 & 9 \\
Larga $(1,60 \mathrm{~m})$ & 280 & 26 & 9 \\
\hline
\end{tabular}

O uso do aço faz com que os dormentes gerem ruídos elevados, além de ter o inconveniente de ter alta condutividade. Outro ponto inconveniente no uso desses dormentes é a dificuldade e a fragilidade das fixações - feita através de parafusos e castanhas -, que requerem manutenção constante. A solução foi o uso de fixação 
GEO (item 2.2.3), contudo essa solução, embora mais moderna e durável, pode se mostrar cara, já que cada perfil de trilho tem uma fixação GEO específica, o que acarretaria em substituição do dormente caso o perfil do trilho seja mudado.

Por ser um dormente relativamente leve, é mais facilmente assentado, porém, não tem boa resposta em vias com tráfego pesado.

O preço de instalação ainda não é um atrativo para este tipo de solução, uma vez que o aço é caro e adequado a diversos outros usos considerados mais nobres.

\subsubsection{Dormentes de plástico}

Os dormentes de plástico são fabricados por extrusão, usando compósitos de plásticos reciclados e fibras de vidro.

O uso do plástico para essa finalidade ainda é relativamente recente, já que os estudos começaram a ser feitos em 1994, pela U. S. Plastic Lumber Corporation. No Brasil, a primeira fabricante desse tipo de dormente foi a Wisewood S/A.

A cor e a forma desses dormentes os associam diretamente com os dormentes de madeira (Figura 2.7), embora os dormentes de plásticos tenham ranhuras e rugosidades que aumentam a resistência lateral.
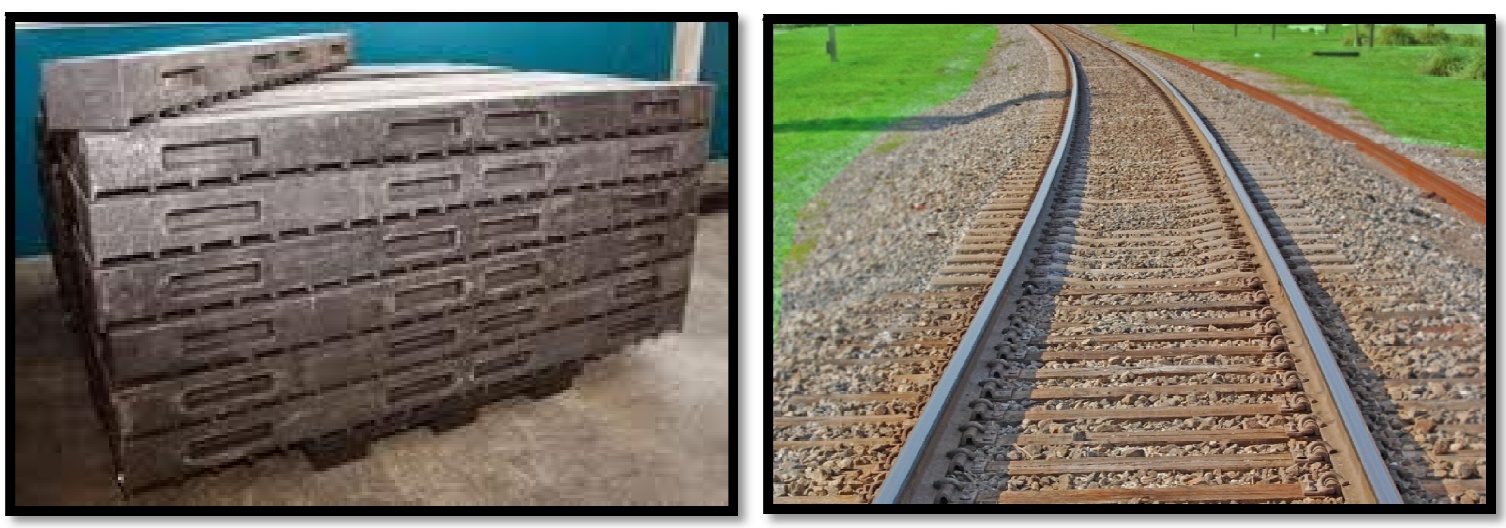

Figura 2.7: Dormentes de plástico. 
As características das peças fabricadas no Brasil estão expressas na Tabela 2.5.

Tabela 2.5: Dimensões dos dormentes de plástico.

\begin{tabular}{c|c|c|c|c}
\hline Bitola & Comprimento (cm) & Largura (cm) & Altura (cm) & Massa (kg) \\
\hline Estreita $(1,00 \mathrm{~m})$ & 200 & 24 & 17 & 70 \\
Padrão $(1,435 \mathrm{~m})$ & 230 & 24 & 17 & 85 \\
Larga $(1,60 \mathrm{~m})$ & 280 & 24 & 17 & 100 \\
\hline
\end{tabular}

Esse tipo de dormente é totalmente reciclável, se mostrando extremamente favorável ao meio ambiente.

\subsubsection{Comparação entre os diferentes materiais usados em dormentes}

Cada material usado na fabricação de dormentes, descrito anteriormente, possui vantagens e desvantagens, as quais devem ser analisadas conjuntamente na hora de escolher qual é o mais adequado para determinada situação.

O Quadro 2.1 apresenta um resumo dessas características de cada um desses materiais.

\begin{tabular}{|l|l|l|}
\hline Material & \multicolumn{1}{|c|}{ Vantagens } & \multicolumn{1}{|c|}{ Desvantagens } \\
\hline \multirow{4}{*}{ Plástico } & $\bullet$ Bom isolante térmico & $\bullet$ Elevado custo inicial \\
& $\bullet$ Totalmente reciclável & \\
& $\bullet$ Elevada vida útil ( $\sim 50$ anos) & \\
& $\bullet$ Impermeável & \\
& $\bullet$ Possibilidade de uso em & \\
& conjunto com dormentes de & \\
& madeira \\
& $\bullet$ Incombustível & \\
\hline
\end{tabular}

Quadro 2.1: Característica de dormentes de acordo com o material de fabricação. 


\begin{tabular}{|c|c|c|}
\hline Material & Vantagens & Desvantagens \\
\hline Concreto & $\begin{array}{l}\text { - Elevada vida útil ( 50 anos) } \\
\text { - Inerte e não tóxico } \\
\text { - Elevada resistência lateral } \\
\text { - Incombustível } \\
\text { - Invulnerável a fungos } \\
\text { - Reciclável }\end{array}$ & $\begin{array}{l}\text { •Possibilidade de } \\
\text { comprometimento da fixação } \\
\text { •Não reutilizável } \\
\text { - Não suporta descarrilamento } \\
\text { • Difícil instalação e manutenção } \\
\text { • Não permite a correção de bitola } \\
\text { •Elevado custo inicial }\end{array}$ \\
\hline Madeira & $\begin{array}{l}\text { - } \text { Bom isolante térmico quando } \\
\text { - Reutilizável } \\
\text { - Fácil instalação e manutenção } \\
\text { - Permite correção de bitola } \\
\text { - Adequada resistência lateral } \\
\text { - Baixo custo inicial } \\
\text { - Rolamento suave } \\
\text { - Boa absorção em } \\
\text { descarrilamentos } \\
\text { - Uso de todo tipo de fixação }\end{array}$ & $\begin{array}{l}\text { - Não pode ser reciclado } \\
\text { - Menor vida útil ( } 25 \text { anos) } \\
\text { - Combustível } \\
\text { - Alta toxidade } \\
\text { - Necessidade de reflorestamento } \\
\text { - Crescente escassez de matéria- } \\
\text { prima }\end{array}$ \\
\hline Ferro & $\begin{array}{l}\text { - Reciclável } \\
\text { - Elevada vida útil ( 60 anos) } \\
\text { - Inerte e não tóxico } \\
\text { - Baixo custo de instalação } \\
\text { - Incombustível } \\
\text { - Elevada estabilidade lateral }\end{array}$ & $\begin{array}{l}\text { - Possibilidade de } \\
\text { - Nomprometimento da fixação } \\
\text { - Difícil substituição } \\
\text { - Não é isolante } \\
\text { - Apresenta problemas para } \\
\text { trilhos longos soldados } \\
\text { - Susceptível à corrosão química } \\
\text { e galvânica }\end{array}$ \\
\hline
\end{tabular}

Quadro 2.1: Característica de dormentes de acordo com o material de fabricação (continuação). 


\subsubsection{Lastro}

Lastro é compreendido como a parte da superestrutura ferroviária que distribui uniformemente na plataforma os esforços da via férrea que são transmitidos através dos dormentes (DNIT, 2011).

Um lastro bem dimensionado, além de resistir bem à ruptura, ao desgaste e às intempéries, tem a função de impedir o deslocamento longitudinal e transversal dos dormentes, através de travamento; corrigir as irregularidades da plataforma, provendo a via com uma superfície continua e uniforme para o assentamento dos dormentes; garantir a elasticidade da via e, quando necessário, facilitar a restauração e manutenção de sua geometria. Além disso, deve permitir a drenagem de águas da superestrutura, com adequada permeabilidade e ventilação e, ainda, evitar bolsas de lama e poeira.

O material comumente usado no lastro é a pedra britada (Figura 2.8), porém podem ser usados outros materiais, como terra, areia, cascalho, escória ou outro material granular. Borges Neto (2010) caracteriza alguns desses materiais usados como lastro da seguinte forma:

i. Terra: o mais barato, porém o de pior qualidade. Normalmente saturável por água, o que causa desnivelamento na linha ("linha laqueada") e, por consequência, descarrilamentos;

ii. Areia: drenante e pouco compressível, entretanto é deslocável com facilidade na presença de água. Produz poeira, que serve de abrasivo ao material rodante e causa desconforto ao rolamento;

iii. $\underline{\text { Cascalho: }}$ lastro com mais qualidade que os anteriores. Possui arestas vivas no caso de sofrer britagem, no entanto pode ser usado na forma natural, encontrada nas cascalheiras, necessitando, contudo, de lavagem para remoção de terra e outras impurezas; 
iv. Escória: material oriundo de usinas siderúrgicas. Alguns possuem a dureza e resistência necessárias à aplicação;

v. Pedra britada: o melhor tipo de lastro, pois resiste bem à abrasão, aos agentes atmosféricos e químicos. Além disso, possui boa permeabilidade, não gera poeira e permite que a via tenha adequada elasticidade e bom nivelamento.
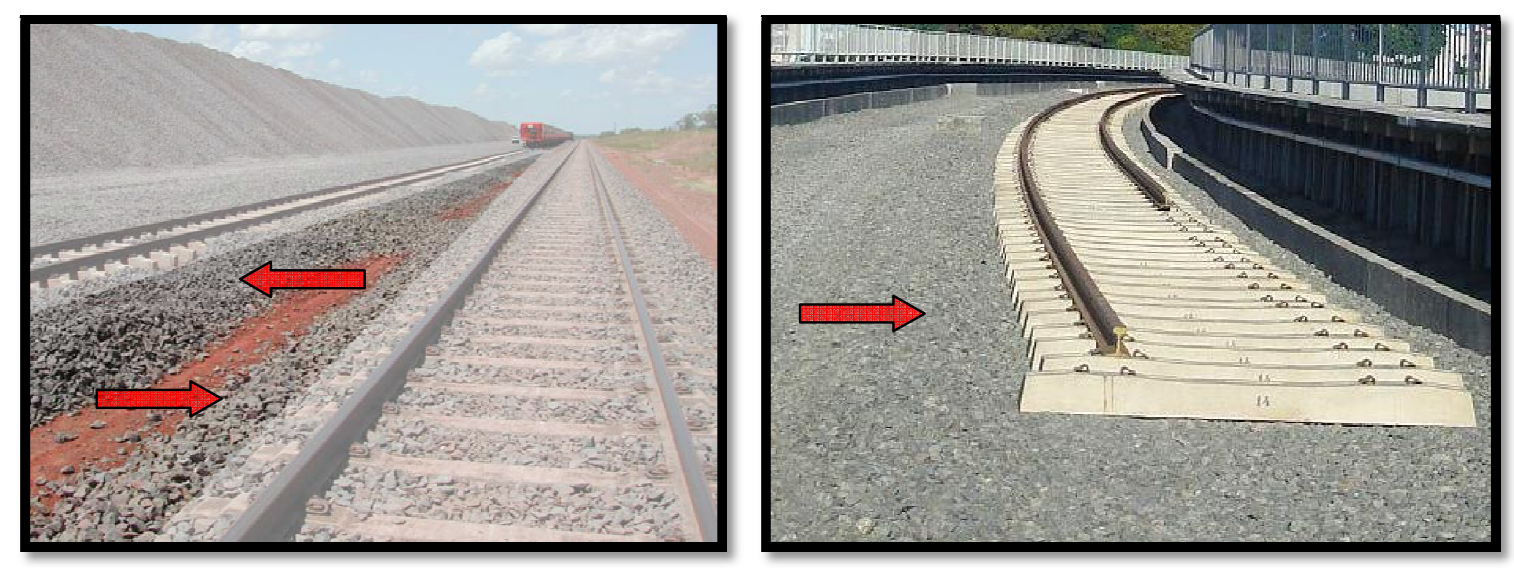

Figura 2.8: Lastro.

As normas brasileiras, para lastros de pedra britada, seguem as normas americanas (American Railway Engineering Association - AREA), padronizando alguns parâmetros:

- Peso específico mínimo: $2,7 \mathrm{tt} / \mathrm{m}^{3}\left(26,5 \mathrm{kN} / \mathrm{m}^{3}\right)$;

- Resistência à ruptura: $700 \mathrm{kgf} / \mathrm{cm}^{2}\left(6,87 \mathrm{kN} / \mathrm{cm}^{2}\right.$ ou $\left.70 \mathrm{MPa}\right)$;

- Solubilidade: Insolúvel;

- Absorção: aumento de peso $\leq 8 \mathrm{gf} / \mathrm{dm}^{3}$;

- Substâncias nocivas: $\leq 1 \%$ (peso) de substâncias nocivas e torrões de argila;

- Granulometria: 3/4" $<\mathrm{d}<21 \frac{1}{2 \prime \prime}(2,0 \mathrm{~cm}<\mathrm{d}<6,0 \mathrm{~cm})$.

Pode-se lançar mão de uma camada intermediária entre o lastro e a plataforma, denominada sublastro. O sublastro é constituído por material menos nobre que o lastro, por isso pode resultar em economia da estrutura, além de melhorar o padrão técnico da superestrutura e diminuir gastos com manutenção. 
O sublastro melhora a elasticidade da via, impede que haja cravamento do lastro na plataforma e a protege contra erosão e penetração de água.

\subsubsection{Acessórios de trilho}

Os acessórios de trilhos são peças que têm a função de fixar os trilhos nos dormentes ou em outros trilhos, nomeados respectivamente de acessórios de fixação e acessórios de ligação.

\subsubsection{Acessórios de fixação}

A função dos acessórios de fixação é ancorar os trilhos aos dormentes. Essa ancoragem pode ser de dois tipos, rígida ou elástica.

\subsection{Fixação rígida}

A fixação rígida, como o próprio nome sugere, não permite flexibilidade aos trilhos, forçando um engastamento. Fixações deste tipo não têm a capacidade de absorver parte dos esforços gerados pela ação do tráfego, como vibrações e impactos. As mais usadas são o prego de linha (ou grampo de linha) e o tirefond (ou tirefão).

i. Prego de linha: é o tipo de fixação mais simples. Tem forma retangular, com seu final em formato de cunha e sua cabeça apresenta uma saliência, que se apoia ao patim (Figura 2.9). A cravação pode ser feita de forma manual, com o uso de marreta, ou mecânica. 


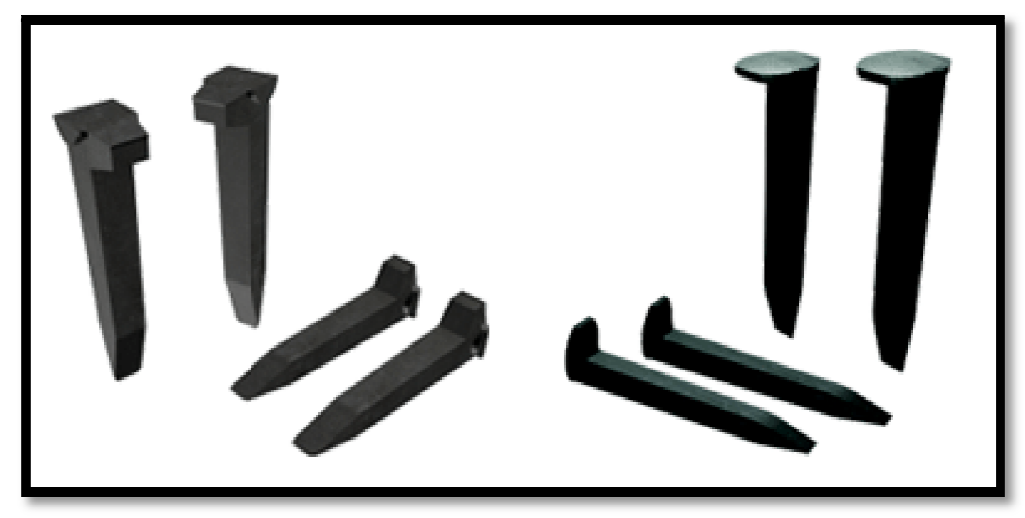

Figura 2.9: Prego de linha.

ii. Tirefond: é um parafuso auto-roscante (rosca soberba), como mostra a Figura 2.10. A fixação no dormente é feita com um equipamento chamado convenientemente de tirefonadeira (Figura 2.11), a qual se encaixa perfeitamente na cabeça do parafuso.

O tirefond apresenta algumas vantagens sobre o prego de linha, como maior resistência ao arrancamento e vedação do furo no dormente, o que impede a entrada de água. O prego de linha sacrifica mais as fibras da madeira, podendo ocasionar até rachadura (BRINA, 1979).

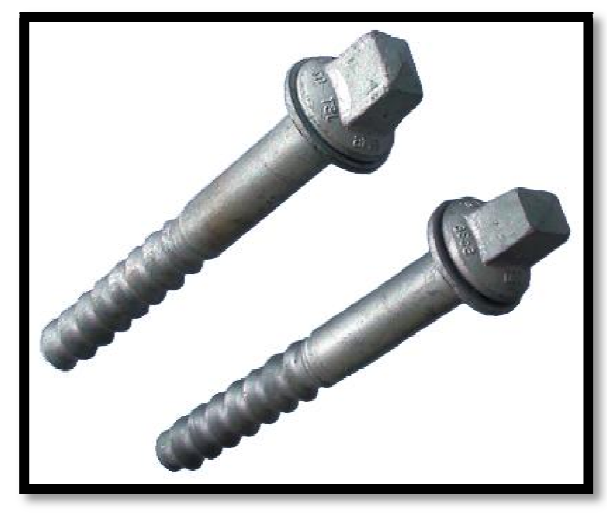

Figura 2.10: Tirefond.

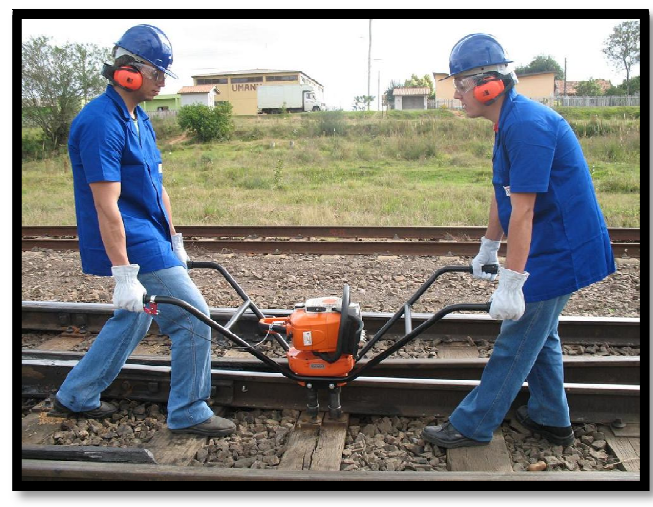

Figura 2.11: Tirefonadeira.

Quando se lança mão de fixação rígida é indispensável o uso de retensores (Figura 2.12), que são acessórios desenvolvidos para impedir o deslocamento longitudinal 
dos trilhos. Os retensores são fixados ao patim por pressão e encostados à lateral do dormente.

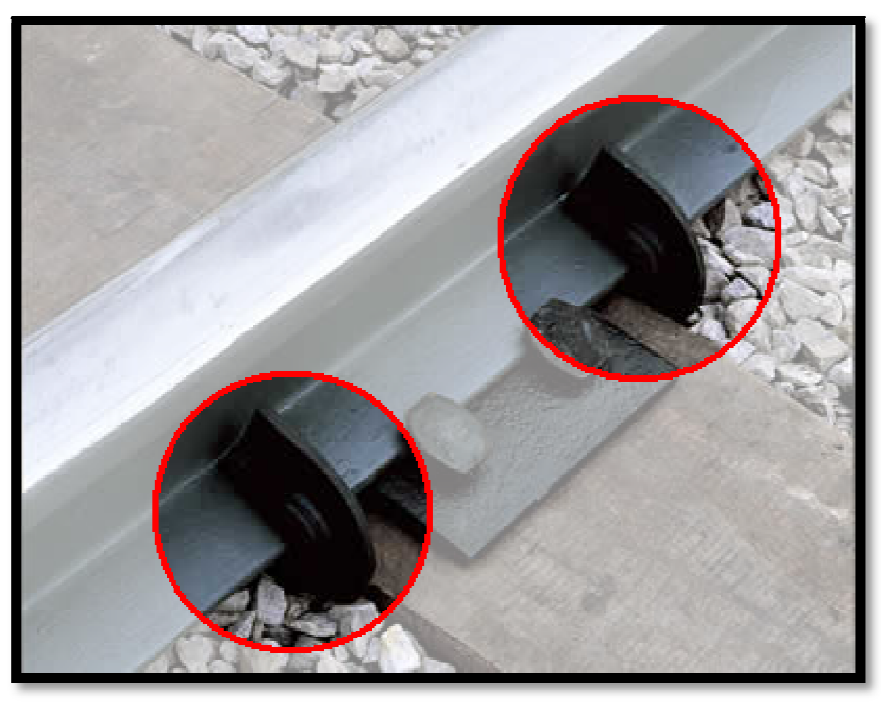

Figura 2.12: Retensores.

\subsection{Fixação elástica}

A fixação elástica permite maior conforto na via ao absorver parte dos esforços da via e permitir que os veículos circulem com mais suavidade. Existem diversos tipos de fixações elásticas no mercado, podendo ser usadas em todos os tipos de dormentes. As mais conhecidas são:

i. Tipo GEO: nesse tipo de fixação há uma placa de aço com nervuras, fixada no dormente, na qual se encaixam parafusos que apertam uma castanha contra o patim (Figura 2.13). O que torna essa fixação elástica é uso de arruelas entre a castanha e o parafuso; 


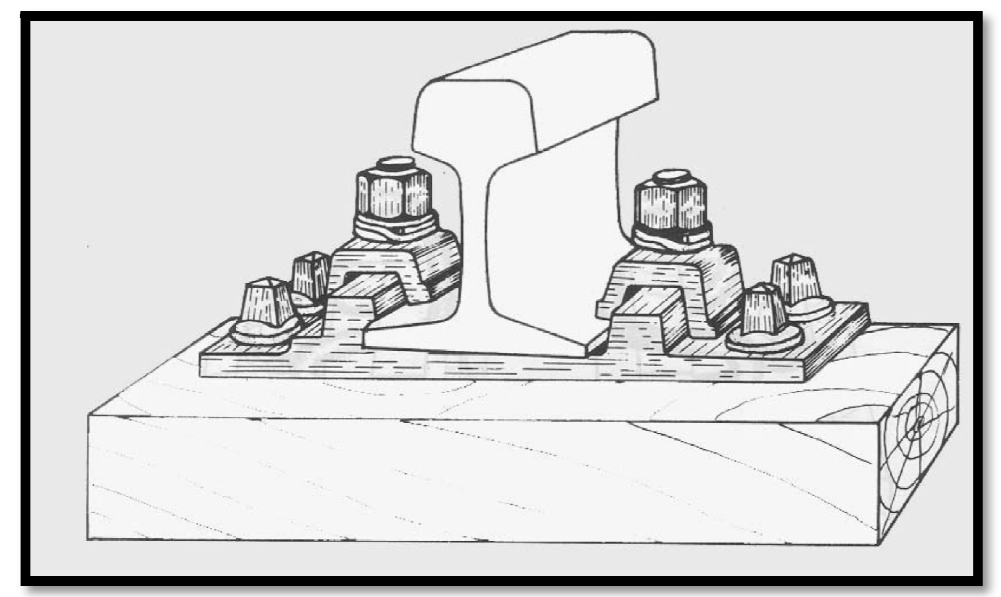

Figura 2.13: Fixação elástica tipo GEO.

ii. Grampo elástico simples: grampo fabricado em aço doce, com a seção da haste, que se fixa ao dormente, aproximadamente quadrada. A parte superior é curva, funcionando como um retensor ao prender o trilho pelo patim (Figura 2.14);

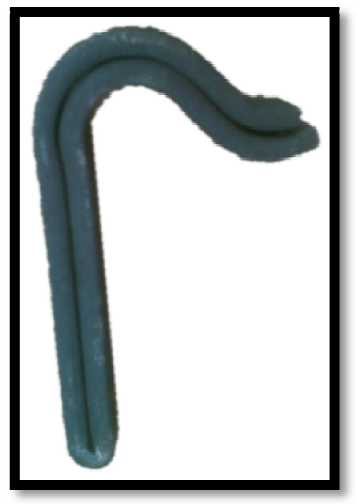

Figura 2.14: Fixação elástica tipo grampo simples.

iii. Grampo elástico duplo: funciona basicamente como o anterior, porém com duas hastes, que se fixam no dormente ou na placa de apoio (Figura 2.15); 


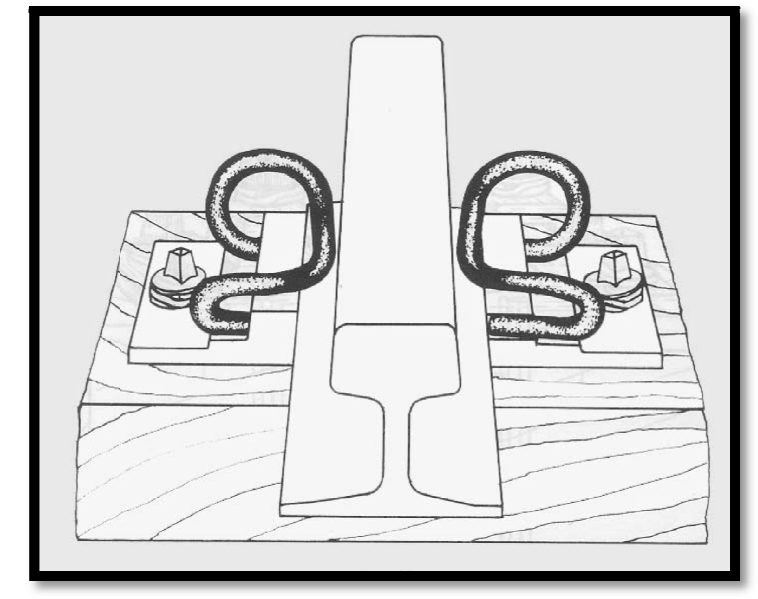

Figura 2.15: Fixação elástica tipo grampo duplo.

iv. Tipo Pandrol: fabricada em aço mola, possui seção circular e prende o trilho pelo patim, com o uso de placas de apoio especiais. Existem diversos modelos a serem usados de acordo com o local desejado (Figura 2.16);
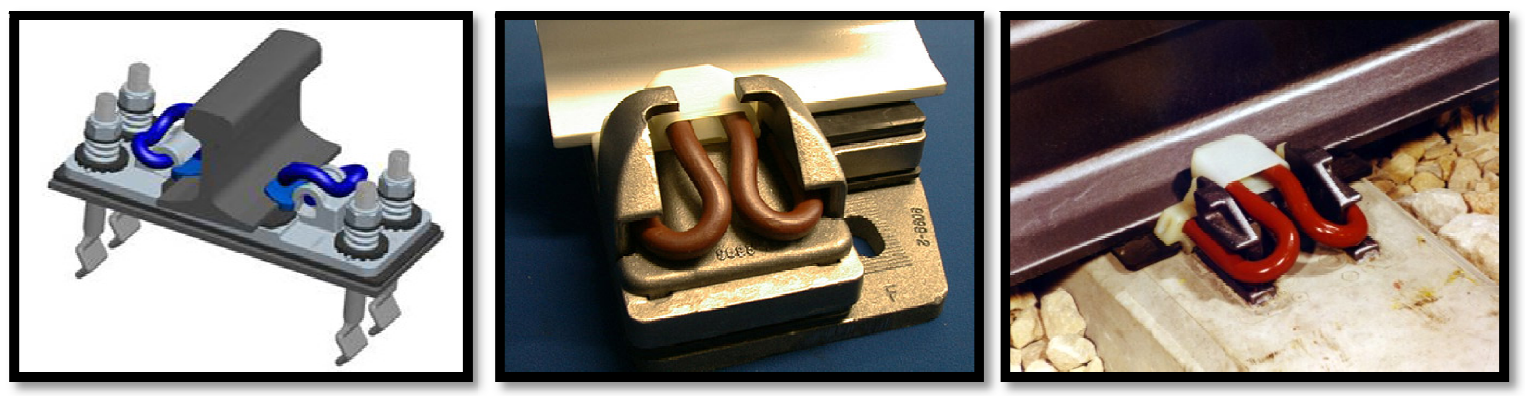

Figura 2.16: Fixação elástica tipo Pandrol.

v. Tipo Deenik: este tipo de fixação (Figura 2.17) permite pequenas movimentações no trilho, dissipando energias como a gerada pela dilatação térmica; 


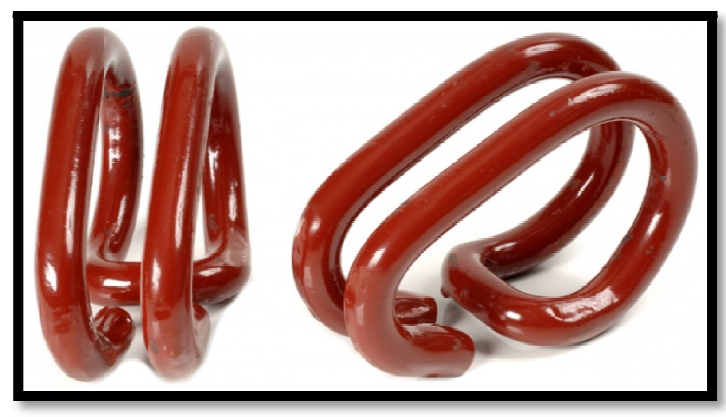

Figura 2.17: Fixação elástica tipo Deenik.

vi. Tipo RN: grampo de aço doce que pressiona o patim contra o dormente (Figura 2.18). Entre a base do patim e o dormente usa-se uma almofada de borracha ranhurada para aumentar a elasticidade do conjunto.

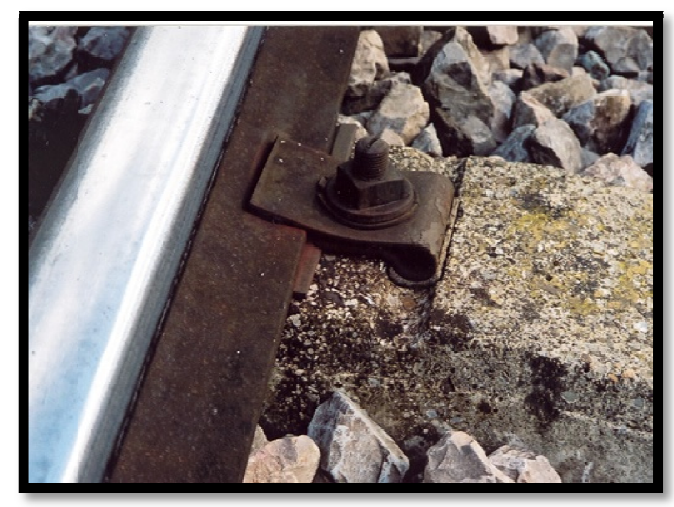

Figura 2.18: Fixação elástica tipo RN.

\subsubsection{Acessórios de ligação}

Tem a função de ligar um trilho a outro, dando continuidade à via. Essa ligação deve ser feita de tal forma que não haja travamento total, garantindo que os esforços devidos à dilatação térmica sejam dissipados, para isso são usadas talas de junção (Figura 2.19), parafusos e arruelas. 


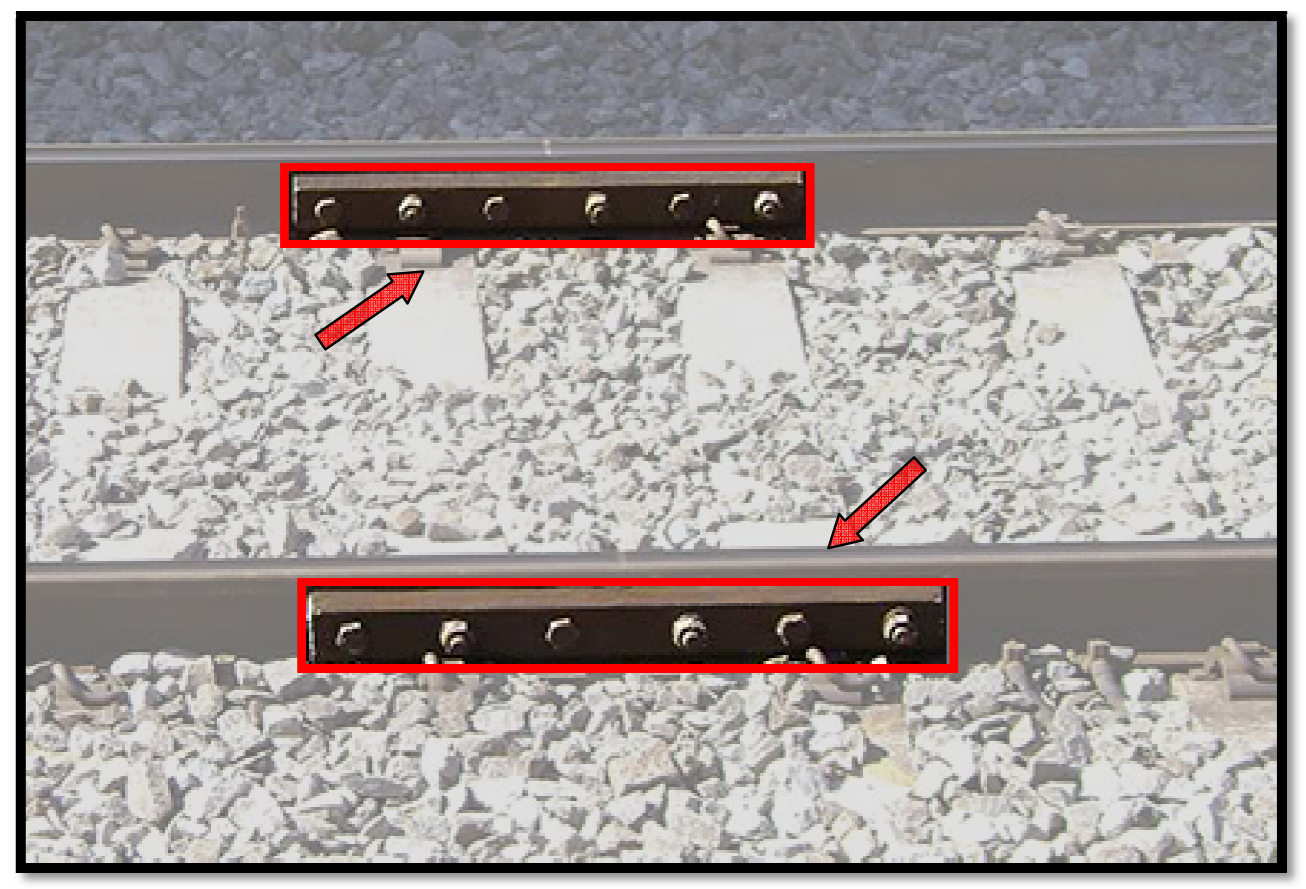

Figura 2.19: Talas de junção.

As talas de junção podem ser angulares ou planas (Figura 2.20) e ter 4 ou 6 furos (Figura 2.21); são posicionadas de ambos os lados da alma do trilho e fixadas com parafusos e arruelas. As dimensões das talas de junção estão apresentadas na Tabela 2.6.

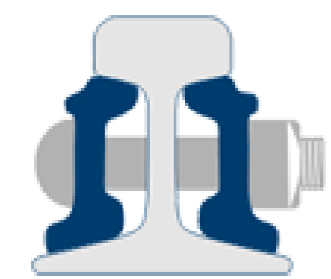

Talas angulares

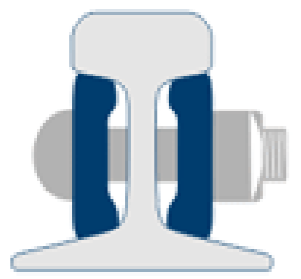

Talas planas

Figura 2.20: Talas de junção - Tipos (Fonte: Brasil Trilhos). 

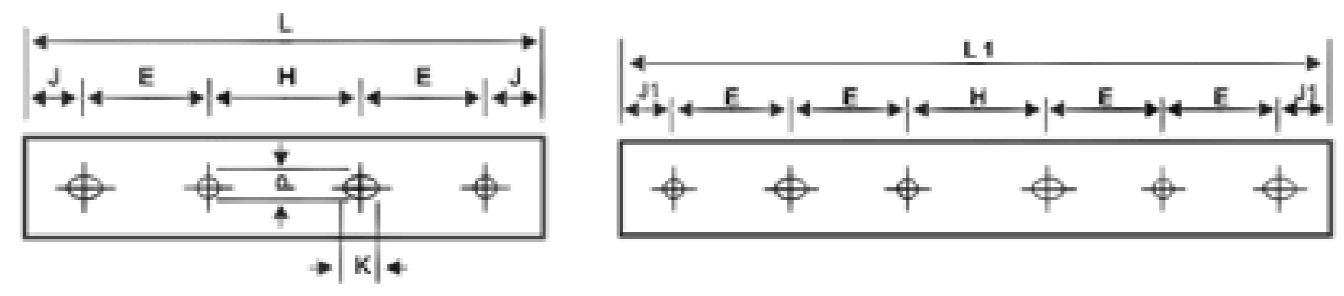

Figura 2.21: Talas de junção - Furos (Fonte: Brasil Trilhos).

Tabela 2.6: Dimensões das talas de junção.

\begin{tabular}{c|c|c|c|c|c|c|c|c|c|c}
\hline \multirow{2}{*}{ Tipo } & \multicolumn{2}{|c|}{ Massa (kg) } & $\mathbf{4}$ & $\mathbf{H}$ & $\mathbf{J}$ & $\mathbf{L}$ & $\mathbf{J 1}$ & $\mathbf{L 1}$ & $\mathbf{P}$ & $\mathbf{K}$ \\
\cline { 2 - 8 } & $\mathbf{f u r o s}$ & furos & $\mathbf{( m m )}$ & $\mathbf{( m m )}$ & $\mathbf{( m m )}$ & $\mathbf{( m m )}$ & $\begin{array}{c}\mathbf{( m m}) \\
(\mathbf{m m})\end{array}$ & $\begin{array}{c}\mathbf{( m m}) \\
\mathbf{( m m})\end{array}$ \\
\hline 25 & 5,8 & - & 139,7 & 139,7 & 95,2 & 609,5 & - & - & 22,2 & 28,6 \\
32 & 8,4 & - & 139,7 & 139,7 & 95,2 & 609,5 & - & - & 22,2 & 28,6 \\
37 & 9,4 & 14,0 & 139,7 & 139,7 & 95,2 & 609,5 & 108,0 & 914,5 & 25,4 & 31,7 \\
45 & 14,0 & 21,1 & 139,7 & 139,7 & 95,2 & 609,5 & 108,0 & 914,5 & 27,0 & 35,7 \\
50 & 15,2 & 22,8 & 139,7 & 139,7 & 95,2 & 609,5 & 108,0 & 914,5 & 27,0 & 35,7 \\
57 & 16,5 & 25,0 & 152,4 & 181,0 & 61,9 & 609,5 & 61,9 & 914,5 & 27,0 & 35,7 \\
68 & 17,1 & 25,6 & 152,4 & 181,0 & 61,0 & 609,5 & 61,9 & 914,5 & 27,0 & 35,7 \\
\hline
\end{tabular}

Fonte: Brasil Trilhos.

Para a fixação das talas de junção ao trilho são usados parafusos comuns (Figura 2.22), com porcas que se encaixam na tala, facilitando o aperto. As arruelas têm a função de evitar o afrouxamento dos parafusos devido à trepidação da linha, sendo mais usada a do tipo grower (Figura 2.23). 


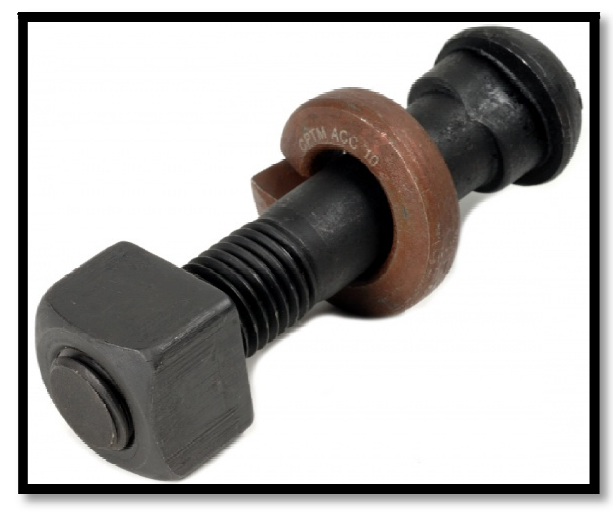

Figura 2.22: Parafuso para tala de junção.

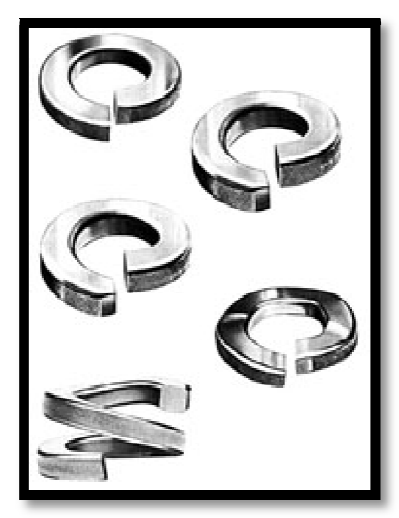

Figura 2.23: Arruelas para talas de junção.

\subsubsection{Placas de apoio}

Comumente, no sistema de fixação, são usadas placas de apoio (Figura 2.24), que são elementos colocados entre o trilho e o dormente com o intuito de aumentar a área de atuação das cargas e, com isso, melhorar a distribuição de esforços e evitar que o trilho corte o dormente. Placas com furos assimétricos são comuns e têm a função de prevenir rachaduras no dormente.
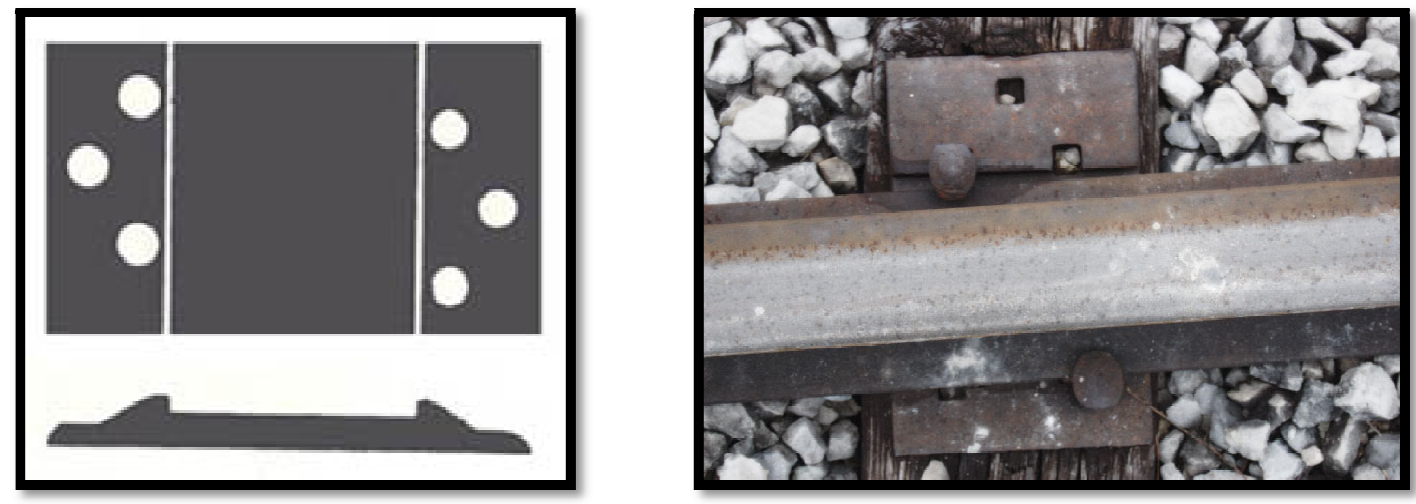

Figura 2.24: Placa de apoio.

As placas de apoio são fabricadas de tal modo que o trilho sobre elas apoiado fique com uma inclinação de 1:20 para o lado interno da via, visando prolongar a vida útil do material rodante e do boleto dos trilhos. 
A leitura de um bom livro é um diálogo incessante:

O livro fala e a alma responde

(André Maurois)

DEFEITOS nA SUPERESTRUTURA DA VIA 3

A via férrea, como qualquer pavimento, está sujeita a defeitos causados pelas ações do tráfego e do clima. Esses defeitos podem ser divididos de várias formas, de acordo com o material constituinte da superestrutura ferroviária ou mesmo uma determinada região que ele ocorra no pavimento ferroviário.

É essencial o conhecimento acerca de cada defeito, onde ocorrem e o porquê, para que se possa tomar a decisão adequada de intervenção e o momento em que a mesma deve ser feita.

Existem máquinas e equipamentos especiais usados para identificar os defeitos, que medem as características da via e identificam os trechos problemáticos. No entanto, essa análise pode ser feita, também, de forma visual, por caminhamento ou em veículo. Embora a inspeção visual tenha rendimento muito menor que a automatizada, ela apresenta bons resultados e ainda é muito usada. 
Identificados os tipos de defeitos e as atividades de manutenção ou reabilitação adequadas, lança-se mão de máquinas e equipamentos próprios para se corrigir cada tipo de defeito em particular.

Neste capítulo são descritos os tipos de defeitos comumente encontrados na superestrutura ferroviária, quais as manutenções recomendadas para cada caso e os tipos de máquinas e equipamentos disponíveis para executarem essas inspeções e intervenções.

\subsection{DEFEITOS}

Os defeitos encontrados na superestrutura da via férrea podem ser divididos basicamente em duas grandes categorias, geométricos ou estruturais. Os defeitos geométricos estão ligados à posição espacial da via e os estruturais aos materiais componentes da superestrutura ferroviária.

Cada tipo de defeito pode se apresentar com grau de degradação distinto, que recebe o nome de severidade, a qual pode ser classificada como baixa, média, alta ou muito alta. Quanto maior o grau de severidade com que um defeito aparece, menor a qualidade geométrica ou estrutural da via.

Nem todos os tipos de defeitos abrangem toda a gama de severidades existentes, pois podem tornar alguns materiais inservíveis ou a geometria estritamente imprópria mesmo antes de chegarem ao grau de severidade mais elevado.

\subsubsection{Defeitos geométricos}

A superestrutura da via férrea é responsável por receber as cargas oriundas do tráfego e direcioná-las de forma adequada ao subleito, sem permitir que o mesmo se rompa ou se deforme de forma excessiva. A resposta da via a essas cargas não é 
puramente elástica; o lastro, por exemplo, responde de forma semielástica, ou seja, parte das deformações às quais o lastro está sujeito permanece de forma residual, gerando diferença com relação à posição original que ele se encontrava, assim como defeitos nos acessórios de fixação, acessórios de ligação ou na colocação dos dormentes podem fazer com que o trilho se afaste da posição original.

Quando o desvio que o trilho sofre com relação à posição original ou à posição para a qual foi projetado acontece fora de limites aceitáveis dá-se o nome de defeito geométrico.

Os defeitos geométricos podem ocorrer transversalmente, longitudinalmente e verticalmente em relação à via ou em forma de torção. Em cada um desses planos é possível dividir os defeitos com relação a variações na bitola, no nivelamento, no alinhamento ou no empeno.

Pode-se, ainda, considerar como defeito a superelevação empregada nas curvas com o intuito de ajudar o veículo a vencer a força centrífuga, desde que passe de valores aceitáveis.

\subsubsection{Defeitos de bitola}

O comprimento da bitola muitas vezes sofre alterações em suas medidas, as quais podem ser divididas em negativas ou positivas. Quando as alterações nas medidas da bitola forem positivas, dá-se o nome de alargamento da bitola (Figura 3.1a) e quando as medidas forem negativas, de estreitamento da bitola (Figura 3.1b).

Variações excessivas na bitola podem fazer com que o trem descarrile ou tenha perda de estabilidade, por isso essas alterações devem ser controladas de forma criteriosa. 


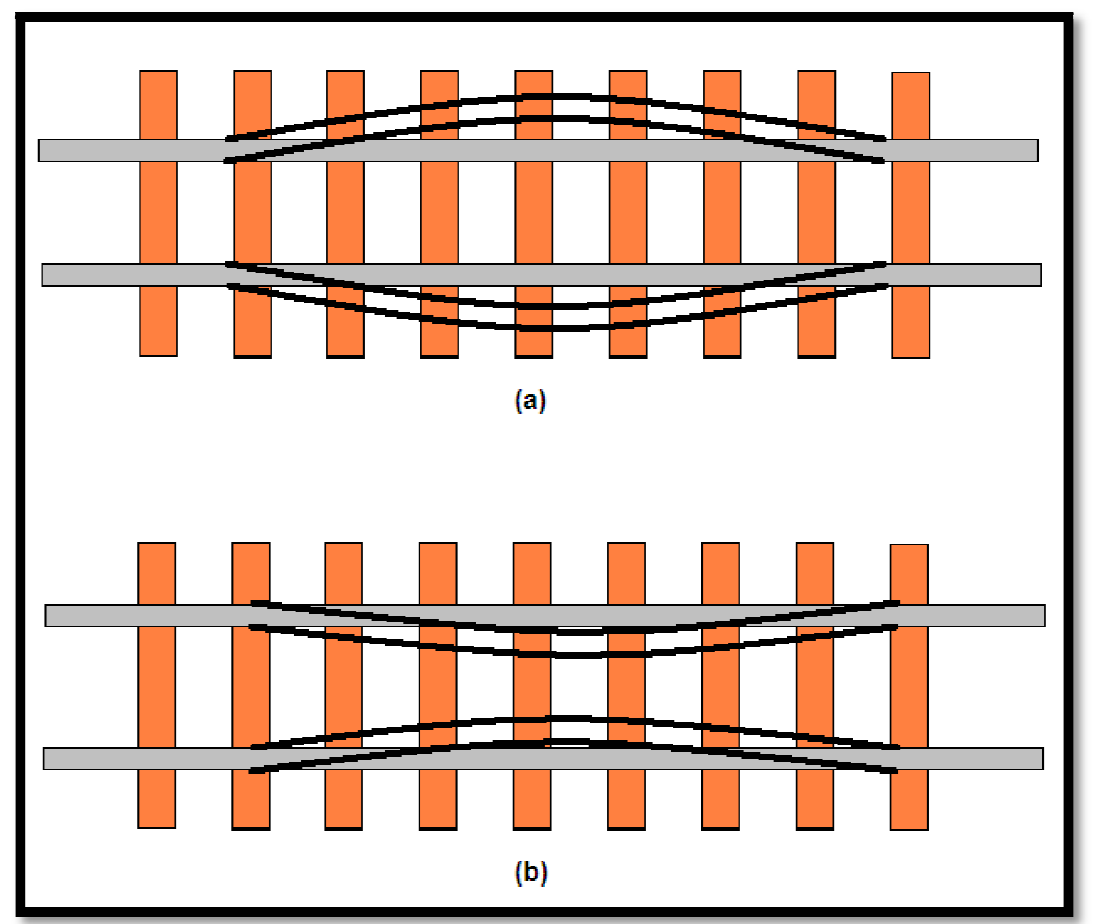

Figura 3.1: Defeitos de bitola.

Normalmente os defeitos na bitola estão associados a problemas em outros componentes da superestrutura, que podem ocorrer:

- Nas placas de ligação, placas de apoio, parafusos e tirefonds soltos ou ausentes;

- Nas juntas quebradas;

- Nos dormentes ou grupos de dormentes deslocados, ausentes ou laqueados;

- Nos boletos desgastados.

A verificação da condição da bitola pode ser feita de três formas:

(i) Bitola máxima e mínima;

(ii) Variação da bitola entre dois dormentes sucessivos;

(iii) Variação máxima da bitola em um determinado comprimento de corda, normalmente de $20 \mathrm{~m}$. 
O controle da bitola é primordial, pois a tolerância às variações é muito baixa, sobretudo a negativa, o que torna este um parâmetro essencial à qualidade da via.

\subsubsection{Defeitos de nivelamento}

O nivelamento da via normalmente é medido de forma longitudinal em cada um dos trilhos separadamente, no entanto também há levantamentos transversais à via.

A diferença de nível entre a posição original do trilho e a deslocada, medida ao longo de uma determinada corda, mostra o quão desnivelado está o trilho (Figura 3.2)

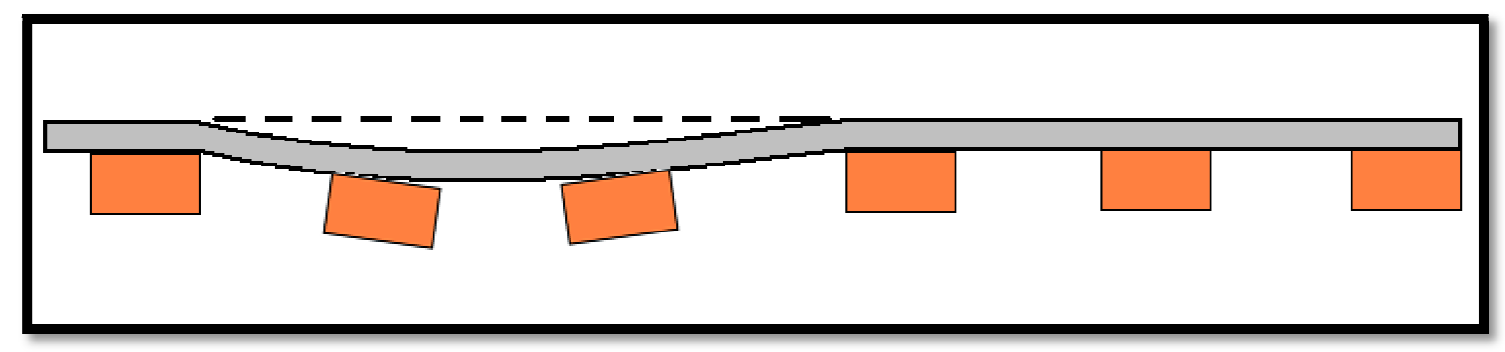

Figura 3.2: Trilho desnivelado.

Normalmente este tipo de defeito está associado à dormentes ou grupo de dormentes ausentes ou laqueados, juntas dos trilhos desniveladas ou soltas, problemas no lastro ou no subleito e trilho corrugado.

A ocorrência de desnivelamento do trilho faz com que a superestrutura esteja sujeita a movimentos de impacto com o material rodante, denominado "movimento de galope", que aumenta o desconforto na viagem, o consumo de energia e a instabilidade, além de proporcionar maiores desgastes ao pavimento ferroviário e às suspensões dos trens.

\subsubsection{Defeitos no alinhamento}

O alinhamento é o eixo de referência para cada trilho ou o local onde a via deve passar. Desvios no alinhamento são permitidos, desde que dentro de determinado limite, além do qual são considerados defeitos. 
Desalinhamentos podem ser medidos separadamente para cada trilho e normalmente estão associados aos problemas de fixação dos trilhos ao dormente, à dormentes laqueados ou a defeitos nos trilhos, como quebra ou deformação.

\subsubsection{Empeno}

Para medir-se o empeno usa-se uma corda de 20 metros e toma-se 4 ou 6 pontos (2 ou 3 em cada trilho) de forma a obter-se um retângulo e o valor do empeno é a diferença que um desses pontos apresenta com relação aos outros que formam o retângulo. Pode-se, também, entender empeno como sendo a máxima diferença entre superelevações medidas dentro de uma determinada corda - normalmente de 20 m (Figura 3.3).

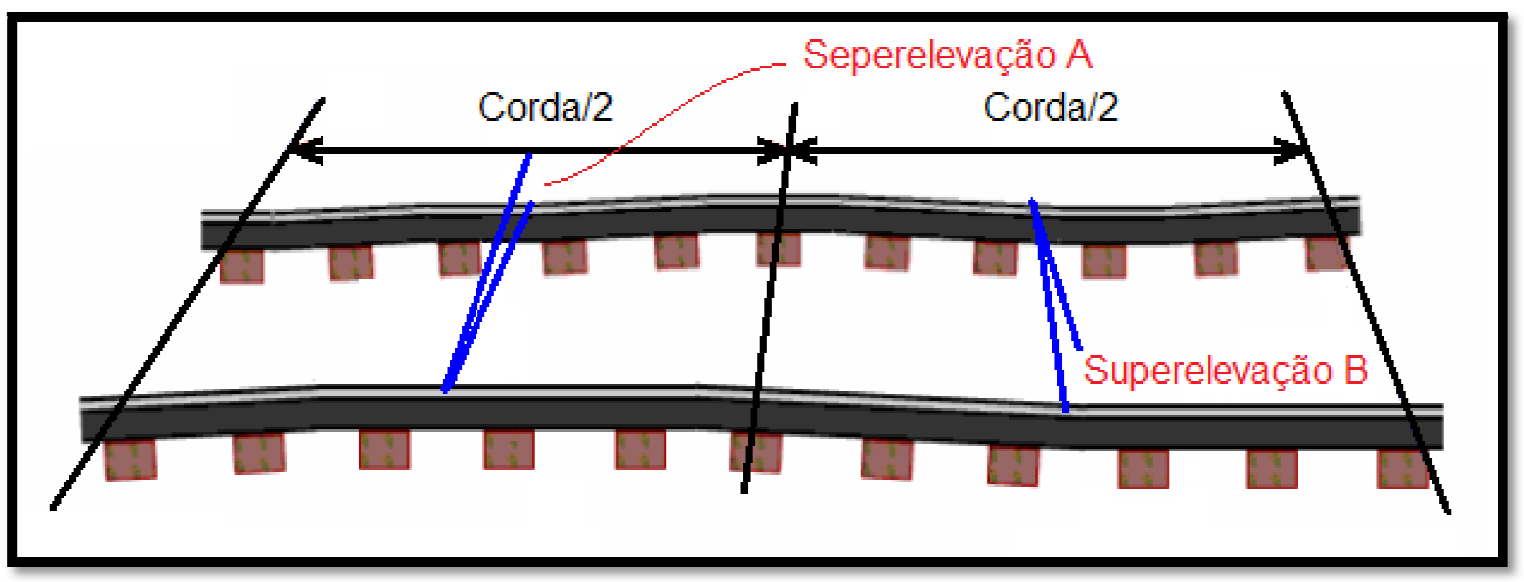

Figura 3.3: Empeno.

Este tipo de defeito também pode receber o nome de torção, do inglês twist, embora quando receba essa terminologia, normalmente está associado à corda de 10 metros.

É importante controlar o empeno de uma via férrea, haja vista que o truque do trem tem elevada rigidez e não acompanha a deformação dos trilhos, o que pode ocasionar descarrilamento. 
Normalmente estão associados a problemas encontrados nos acessórios de fixação, nos dormentes ou no próprio trilho.

\subsection{DEFEITOS ESTRUTURAIS}

Os defeitos estruturais referem-se a problemas nos materiais que compõem a via férrea e, portanto, podem ser divididos conforme esses materiais. É comum a ocorrência de alguns tipos de defeitos associados ou em conjunto e o conhecimento desse fato é de extrema importância no planejamento das intervenções, bem como no cálculo de custos.

\subsubsection{Defeitos nos trilhos}

\section{Definição:}

Defeitos nos trilhos abrangem tudo o que reduz a força ou a funcionalidade do trilho. De acordo com o manual do RAILER, que é o programa de gerência de vias férreas proposto pelo Corpo de Engenheiros do Exército Americano (USACERL, 1998), há trinta e três defeitos internos e externos que são possíveis de ocorrerem nos trilhos e podem ser separados dentro de níveis específicos de severidade. Vale salientar que as unidades foram convertidas do padrão inglês para o padrão internacional e os arredondamentos em função disto.

\section{Classificação:}

Severidade baixa:

- Trilho dobrado;

- Lascas ou dentes no boleto $\geq 6 \mathrm{~mm}$;

- Corrugações;

- Queima do boleto por patinação $\geq 6 \mathrm{~mm}$; 
- Descamação;

- Defeitos de fabricação;

- Alargamento $\geq 6 \mathrm{~mm}$;

- Comprimento do trilho <3,96 m;

- Trincas superficiais no boleto;

- Lascas superficiais fora do boleto.

Severidade média:

- Trinca na furação da alma $\leq 13 \mathrm{~mm}$;

- Trinca na base $\leq 15 \mathrm{~cm}$;

- Fissura composta $\leq 20 \%$ da área;

- Corrosão na base;

- Esmagamento do boleto;

- Fratura detalhada $\leq 20 \%$ da área;

- Depressão na superfície de rolamento da junta > $6 \mathrm{~mm}$;

- Ruptura devido à queima do boleto por patinação $\leq 20 \%$ da área;

- Trincamento na concordância entre alma e boleto $\leq 6 \mathrm{~mm}$;

- Trinca horizontal no boleto $\leq 5 \mathrm{~cm}$;

- Encanamento de trilho $\leq 13 \mathrm{~mm}$;

- Dano na superfície de rolamento;

- Desgaste lateral;

- Trinca na alma $\leq 13 \mathrm{~mm}$;

- Corte no trilho feito por maçarico;

- Fissura transversal $\leq 20 \%$ da área;

- Trinca vertical no boleto $\leq 5 \mathrm{~cm}$;

- Desgaste vertical.

Severidade alta:

- Trinca na furação da alma $>13 \mathrm{~mm}$ e $\leq 38 \mathrm{~mm}$;

- Trinca na base $>15 \mathrm{~cm} \mathrm{e} \leq 30 \mathrm{~cm}$;

- Fissura composta $>20 \%$ e $\leq 40 \%$ da área;

- Fratura detalhada $>20 \%$ e $\leq 40 \%$ da área; 
- Ruptura devido à queima do boleto por patinação > 20\% e $\leq 40 \%$ da área;

- Trincamento na concordância entre alma e boleto > $13 \mathrm{~mm}$ e $\leq 76 \mathrm{~mm}$;

- Trinca horizontal no boleto $>5 \mathrm{~cm}$ e $\leq 10 \mathrm{~cm}$;

- Encanamento de trilho $>13 \mathrm{~mm}$ e $\leq 76 \mathrm{~mm}$;

- Trinca na alma > $13 \mathrm{~mm}$ e $\leq 76 \mathrm{~mm}$;

- Furo por maçarico;

- Fissura transversal $>20 \%$ e $\leq 40 \%$ da área;

- Trinca vertical no boleto $>5$ e $\leq 10 \mathrm{~cm}$;

- Defeitos na solda.

Severidade muito alta:

- Trinca na furação da alma > $38 \mathrm{~mm}$ ou quebra;

- Trinca da base $>30 \mathrm{~cm}$;

- Quebra completa - limpa e quadrada ou áspera e angular;

- Fissura composta $>40 \%$ da área;

- Ruptura detalhada $>40 \%$ da área;

- Ruptura devido à queima do boleto por patinação > 40\% da área;

- Trincamento na concordância entre alma e boleto > 76 mm ou quebra;

- Trinca horizontal no boleto $>10 \mathrm{~cm}$ ou quebra;

- Encanamento de trilho $>76 \mathrm{~mm}$ ou quebra;

- Fenda na alma > $76 \mathrm{~mm}$ ou quebra;

- Fissura transversal > 40\% da área;

- Trinca vertical no boleto $>10 \mathrm{~cm}$ ou quebra.

\section{Medicão:}

As medidas dos defeitos devem ser executadas em cada trilho separadamente e deve-se contar o número de vezes que cada defeito ocorre em cada trilho, exceto para defeitos de severidade baixa, os quais só devem ser contados se houver presença de defeitos diferentes em um dado trilho (isto é, não contar o número de lascas, local de bombeamento etc.) 
Os trilhos com mais de 12 metros devem ser divididos em trilhos-equivalentes com comprimento de 12 metros ou menos. A densidade dos defeitos é determinada por:

$$
\text { Densidade }=\frac{N^{\circ} \text { de trilhos afetados com dado número de ocorrência de defeitos }}{N^{\circ} \text { de trilhos da unidade da amostra }}
$$

\section{Causa:}

Defeitos em trilho resultam de problemas de controle de qualidade no processo de fabricação, instalação imprópria ou manuseio impróprio, falta de manutenção e efeitos ambientais. Além disso, repetidas solicitações das cargas de roda induzem às tensões e deformações excessivas ou repetidas, levando a danos por fadiga, desgaste e fluência do metal.

\subsubsection{Defeitos nas juntas}

\section{Definição:}

Defeitos nas juntas incluem todos os itens que reduzem a resistência ou funcionalidade das juntas.

\section{Classificação:}

Severidade baixa:

- Tala de junção quebrada ou trincada (não no centro);

- Parafuso defeituoso ou faltando;

- Tala de junção de tamanho ou tipo impróprio;

- Parafuso de tamanho ou tipo impróprio;

- Parafuso solto;

- Solda ou tala de junção alterada. 
Severidade média:

- Todos os parafusos da junta soltos;

- Tala de junção corroída;

- Uma tala de junção quebrada no centro ou faltando;

- Uma tala de junção trincada no centro;

- Somente um parafuso por final de trilho;

- Espaçamento entre trilhos > $25 \mathrm{~mm}$ e $\leq 50 \mathrm{~mm}$;

- Incompatibilidade entre trilhos subsequentes $>5 \mathrm{~mm}$ e $\leq 6 \mathrm{~mm}$.

Severidade alta:

- As duas talas de junção quebradas no centro.

Severidade muito alta:

- Todos os parafusos para ligação de trilhos quebrados ou faltando;

- As duas talas de junção faltando;

- Espaçamento entre trilhos > $50 \mathrm{~mm}$;

- Incompatibilidade entre trilhos subsequentes $>6 \mathrm{~mm}$.

\section{Medicão:}

As medidas devem ser feitas em todas as juntas e para cada defeito (p. ex. parafuso solto é considerado uma ocorrência separada em cada junta). Entretanto, como aplicação, somente os mais altos níveis de severidade devem ser registrados para um componente específico (p.ex., se um defeito de severidade muito alta referente a todos os parafusos quebrados ou faltando em um final de trilho, o defeito de severidade baixa referente a um defeito individual de parafusos faltando não é contado para o mesmo final de trilho). 
Quando os trilhos forem maiores que 12 metros, deve-se dividi-los em trilhosequivalentes de 12 metros. A quantidade de defeitos por trilho é dada por:

$$
\text { Densidade }=\frac{N^{\circ} \text { de juntas afetadas com dado número de ocorrência de defeitos }}{N^{\circ} \text { de juntas da unidade da amostra }}
$$

\section{Causa:}

Defeitos em juntas resultam de instalação imprópria, falta de manutenção e efeitos ambientais. A carga de roda repetida também induz tensões, deflexões e vibrações que conduzem à fadiga e a parafusos e talas soltos.

\subsubsection{Defeitos nos acessórios de fixação}

\section{Definição:}

Acessórios de fixação são considerados defeituosos se eles falham em fixar o trilho adequadamente ao dormente ou se eles são colocados em padrão ou posição impróprios.

\section{Classificacão:}

Severidade baixa:

- Padrão ou posição impróprios.

\section{Severidade média:}

- Acessórios de fixação soltos, dobrados, quebrados, faltantes ou com defeitos diversos. 


\section{Medicão:}

Se os pregos ou outros acessórios estão soltos ou faltando devido ao defeito ser do dormente, este defeito não deve ser contado. A medição é feita em cada prego, clipe etc. e a densidade é dada por:

$$
\text { Densidade }=\frac{N^{\circ} \text { de pregos defeituosos etc. }}{N^{\circ} \text { de dormente na amostra } \times 4}
$$

Há necessidade de se multiplicar o denominador por 4, pois são usados 4 pregos ou parafusos por unidade.

\section{Causa:}

Defeitos nos acessórios de fixação ocorrem devido à instalação imprópria, dormentes defeituosos, vibrações e deflexões impostas pelas operações do tráfego.

\subsubsection{Defeitos nas placas de apoio}

\section{Definição:}

Placas de apoio são consideradas defeituosas se elas estiverem em posição imprópria, trincadas, dobradas, quebradas ou corroídas.

\section{Medição:}

Nesse tipo de defeito não são considerados níveis de severidade e a densidade é dada por:

$$
\text { Densidade }=\frac{N^{\circ} \text { de placas de apoio defeituosas }}{N^{\circ} \text { de dormente } \text { na amostra } \times 2}
$$


Há necessidade de se multiplicar o denominador por 2, pois são usados 2 placas de apoio por dormente.

\section{Causa:}

Placas de apoio defeituosas geralmente ocorrem por manuseio ou instalação impróprios, dormentes defeituosos e acessórios de fixação faltantes. Vibrações, deflexões e excessiva carga de roda imposta pelas operações do tráfego podem causar danos às placas de apoio, como quebra, dobra ou trinca por fadiga.

\subsubsection{Defeitos nos dormentes}

Os defeitos são considerados diferentemente em dormentes isolados ou em grupos.

\subsubsection{Dormentes isolados}

\section{Definição:}

Podem ser considerados defeituosos se estiverem ocos, podres, deslocados, danificados a ponto de não permitirem fixação, quebrados, cortados ou deteriorados. Podem ser alocados de acordo com a severidade em:

\section{Classificacão:}

Severidade baixa:

- Localizados em qualquer parte, desde que não na junta dos trilhos e danificado até $10 \%$.

\section{Severidade média:}

- Localizados em qualquer parte, desde que não na junta dos trilhos e danificado mais que $10 \%$. 
Severidade alta:

- Localizados na junta dos trilhos e danificado até $10 \%$.

Severidade muito alta:

- Localizados na junta dos trilhos e danificado mais que $10 \%$.

\section{Medição:}

A densidade desse defeito é dada por:

$$
\text { Densidade }=\frac{N^{\circ} \text { de dormentes defeituosos }}{N^{\circ} \text { de dormentes na amostra }}
$$

\section{Causa:}

Os defeitos podem ser oriundos de causas naturais, como apodrecimento, infestação de insetos, trincas ou quebra por envelhecimento. Podem aparecer também devido a fatores climáticos, má drenagem, desgaste mecânico, falta de suporte do lastro, má instalação, descarrilamento etc.

\subsubsection{Dormentes faltando}

\section{Definicão:}

A ausência de um ou mais dormentes indica o nível de severidade. O número de dormentes faltando pode ser de no máximo 3 por grupo; quando exceder esse valor, devem ser considerados grupos distintos. 


\section{Classificacão:}

Severidade baixa:

- Um dormente faltando.

Severidade média:

- Dois dormentes faltando.

Severidade alta:

- Três dormentes faltando.

\section{Medição:}

A densidade deste defeito é dada por:

Densidade $($ severidade baixa $)=\frac{N^{\circ} \text { grupos }}{N^{\circ} \text { de dormentes na amostra }}$

Densidade $($ severidade média $)=\frac{N^{\circ} \text { grupos } \times 2}{N^{\circ} \text { de dormentes na amostra }}$

Densidade $($ severidade alta $)=\frac{N^{\circ} \text { grupos } \times 3}{N^{\circ} \text { de dormentes na amostra }}$

\subsubsection{Dormentes mal posicionados}

\section{Definição:}

São considerados dormentes mal posicionados quando estiverem inclinados, rotacionados ou agrupados. 


\section{Classificacão:}

Os três graus de severidade que este defeito pode apresentar variam de acordo com a rotação no eixo longitudinal, a inclinação ou o agrupamento.

Severidade baixa:

- Variações até $20 \mathrm{~cm}$.

Severidade média:

- Variações maiores que $20 \mathrm{~cm}$, mas que não estejam em junta de trilhos.

Severidade alta:

- Variações maiores que $20 \mathrm{~cm}$ e que estejam em junta de trilhos.

\section{Medição:}

A densidade deste defeito é calculada por:

$$
\text { Densidade }=\frac{N^{\circ} \text { dormentes mau posicionados }}{N^{\circ} \text { de dormentes na amostra }}
$$

\section{Causa:}

As causas deste defeito podem ser instalação imprópria, baixo suporte do lastro, movimentos dos trilhos, vibrações e deflexões causadas pelo tráfego.

\subsubsection{Grupos de dormentes}

\section{Definição:}

São considerados nessa categoria se dois ou mais dormentes seguidos estiverem defeituosos. A severidade é computada de acordo com o número de dormentes até 
no máximo 5. Caso haja mais que cinco dormentes defeituosos, devem-se considerar grupos distintos.

\section{Classificação:}

Severidade baixa:

- Dois dormentes consecutivos defeituosos.

Severidade média:

- Três dormentes consecutivos defeituosos.

Severidade alta:

- Quatro dormentes consecutivos defeituosos.

Severidade muito alta:

- Cinco dormentes consecutivos defeituosos.

\section{Medicão:}

As medições devem ser feitas por grupo e a densidade é calculada por:

$$
\begin{gathered}
\text { Densidade (severidade baixa) }=\frac{N^{\circ} \text { grupos } \times 2}{N^{\circ} \text { de dormentes na amostra }} \\
\text { Densidade (severidade média) }=\frac{N^{\circ} \text { grupos } \times 3}{N^{\circ} \text { de dormentes na amostra }} \\
\text { Densidade (severidade alta) }=\frac{N^{\circ} \text { grupos } \times 4}{N^{\circ} \text { de dormentes na amostra }} \\
\text { Densidade (severidade muito alta) }=\frac{N^{\circ} \text { grupos } \times 5}{N^{\circ} \text { de dormentes na amostra }}
\end{gathered}
$$




\subsubsection{Defeitos no lastro}

Os defeitos mais comuns no lastro são:

- Lastro contaminado;

- Crescimento de vegetação;

- Deformação permanente;

- Continuidade em cabeceiras de pontes;

- Bombeamento;

- Lastro insuficiente;

- Erosão.

O lastro é considerado contaminado se há presença de materiais finos preenchendo os vazios presentes na composição de agregados graúdos. Esse material fino pode ser proveniente do subleito, de resíduos de materiais transportados, carreados pelo vento ou água etc. O lastro também pode se desintegrar devido à abrasão mecânica ou química e o material fino acaba preenchendo os vazios. Outro problema relacionado ao lastro é o pumping.

\subsection{EQUIPAMENTOS PARA MANUTENÇÃO}

A conservação das vias férreas deve ser feita de forma adequada e o mais rápido possível, seja para manter as características geométricas ou estruturais. Para isso, lança-se mão de máquinas e equipamentos próprios que podem ser divididos em leves ou especiais. Os equipamentos considerados leves são aqueles portáteis; já os especiais, são aqueles de grande porte, normalmente autopropulsores e, muitas vezes, servo-controlados. 


\subsubsection{Equipamentos leves}

Os equipamentos leves, embora recebam essa nomenclatura, são equipamentos geralmente robustos, precisos e de baixo custo operacional. Os mais comuns deste grupo são:

i. Tirefonadora: equipamento usado para apertar e desapertar tirefonds. Possibilita a mudança rápida de um trilho para outro ao deslizar a cabeça giratória de um lado a outro por meio de guias;

ii. Serra móvel para trilhos: permite ser fixada e faz o corte preciso de trilhos;

iii. Máquina para perfurar trilhos: projetada para trabalhar horizontalmente, possui um sistema de avanço para garantir a posição exata dos furos;

iv. Rebarbadora de solda: usada para retirar rebarbas do boleto quando os trilhos sofrem processo de solda, ela minimiza o trabalho posterior de esmerilhamento;

v. Esmerilhadora portátil: para esmerilhamento de juntas e boletos de trilhos. Permite um ângulo de giro de até $90^{\circ}$;

vi. Máquina para perfuração de dormentes: equipamento usado para a furação para colocação de tirefonds em dormentes;

vii. Socadora vibratória manual: usados para socaria do lastro, sob o dormente, em pequena escala;

viii. Régua de bitola: usada para diminuir ou aumentar a bitola. É fixada por meio de parafusos; 
ix. Tensionador de trilhos: usado para tracionar, comprimir e fixar os trilhos durante os trabalhos de soldagem;

x. Máquina para deslocamento de trilhos: usada para o posicionamento continuo de trilhos de acordo com a bitola e o alinhamento desejados;

xi. Máquina para parafusar talas: equipamento usado para colocar os parafusos nas talas. Tem mandril ajustável que permite maior rapidez;

xii. Máquina de clipagem: usada para inserir e extrair estribos de clips de fixação.

\subsubsection{Equipamentos especiais}

As máquinas especiais são equipamentos capazes de realizarem manutenções rapidamente, com segurança e em grande escala na via férrea. O avanço da tecnologia permite máquinas cada vez mais precisas e rápidas, muitas vezes servocontroladas.

Neste grupo, as máquinas mais comuns são:

i. Socadora: são máquinas que fazem a socaria do lastro, normalmente por pressão e por vibração. As socadoras atuais são capazes de executarem o serviço tanto na via corrida quanto nos aparelhos de mudança de via. A socadora, ao erguer os trilhos e dormentes é, também, capaz de realizar o alinhamento e o nivelamento dos mesmos, enquanto realiza o serviço de socaria; 
ii. Desguarnecedora: realiza a limpeza do lastro. Esta máquina retira o lastro desgastado ou quebrado, realiza o peneiramento e devolve o material granulometricamente adequado ao local, completando com o material necessário ao nivelamento;

iii. Esmerilhadora: a função deste equipamento é regularizar a superfície do trilho, desgastando o boleto e, assim, uniformizando as tensões internas nos trilhos e permitindo maior conforto ao rolamento;

iv. Reguladora: serve para ajustar a quantidade de lastro, retirando o excesso ou completando o material faltando. Normalmente é usada após o processo de socaria;

v. Reperfiladora: equipamento usado para redesenhar o boleto por meio de desgaste do trilho. 
Nas grandes batalhas da vida,

O primeiro passo para a vitória é o desejo de vencer.

(Mahatma Gandhi)

Sistemas de gerêncIa

Segundo Haas, Hudson e Zaniewski (1994), um sistema de gerência de pavimentos (SGP) consiste em um conjunto amplo coordenado de atividades associadas com planejamento, projeto, construção, manutenção, avaliação e pesquisa, com o propósito de fornecer e manter pavimentos em um nível adequado de serviço.

A função de um sistema de gerência de pavimentos é propiciar pavimentos seguros, confortáveis e econômicos. Para atingir esses objetivos, um sistema de gerência de pavimentos deve ser capaz de comparar, priorizar e alocar os recursos destinados à manutenção e reabilitação da malha viária da forma mais adequada. Além disso, deve considerar estratégias alternativas, tomar decisões com base em critérios e restrições orçamentárias, permitir ser realimentável com informações novas e considerar as consequências das decisões tomadas (PETERSON, 1987). 


\subsection{AVALIAÇÕES DE PAVIMENTOS}

A qualidade de um sistema de gerência de pavimentos está diretamente ligada à quantidade e qualidade de dados coletados da via, obtidos através de avaliação, que pode ser executada de forma subjetiva ou objetiva.

A avaliação de caráter subjetivo está diretamente ligada ao conceito de serventia, introduzido por Carey e Irick ao realizarem o AASHO Road Test. A serventia consiste na habilidade de uma determinada seção de pavimento, à época da observação, de servir ao tráfego com elevados volumes e altas velocidades. A avaliação da serventia ao longo do tempo fornece o desempenho do pavimento (FERNANDES JR, ODA e ZERBINI, 2006).

A avaliação subjetiva é realizada por um grupo de avaliadores experientes que atribuem notas para cada seção do pavimento, fornecendo o valor de serventia atual (VSA). Posteriormente, essas notas são relacionadas com valores obtidos por meio de medidas físicas de defeitos e, lançando-se mão de estatística, obtém-se o índice de serventia atual (ISA) do pavimento.

A avaliação objetiva foca no levantamento de defeitos de seções do pavimento com o uso de equipamentos de medição. Faz parte da avaliação objetiva o reconhecimento do tipo de defeito, sua frequência e severidade, bem como a possível causa do defeito.

\subsection{NÍVEIS ADMINISTRATIVOS}

A gerência de pavimentos pode ser subdividida em dois grupos, dependendo do objetivo do estudo e o tipo de resposta desejado, podendo ser em nível de rede ou nível de projeto. 


\subsubsection{Gerência em nível de rede}

Segundo Fernandes Jr., Oda e Zerbini (2006), a gerência em nível de rede trabalha com informações relacionadas a toda malha viária e tem a função de tomar decisões de caráter administrativo, como planejamento, programação e orçamento. As principais características da gerência em nível de rede estão relacionadas com a identificação e priorização de projetos, geração de necessidades de orçamentos e análise de estratégias de intervenção.

As intervenções podem ser de caráter corretivo, preventivo, de ação postergada reforço ou reconstrução.

\subsubsection{Gerência em nível de projeto}

A gerência em nível de projeto passa o "pente fino" na malha viária ao trabalhar com informações detalhadas das seções. Essas informações compreendem diagnósticos detalhados dos defeitos, o que pode tê-los gerado e os métodos corretivos aplicáveis.

É função da gerência em nível de projeto selecionar as atividades de manutenção, reabilitação e reconstrução, fornecer dados com relação ao desempenho do pavimento e definir parâmetros para projetos estruturais, como resistência do subleito, número de solicitações do eixo padrão e especificação para os materiais.

\subsection{IMPLEMENTAÇÃO DE SISTEMAS DE GERÊNCIA}

A implementação de um sistema de gerência está relacionada à realidade, necessidade e possibilidade dos órgãos responsáveis pela manutenção dos pavimentos e, com isso, cada órgão viário pode ter o seu próprio sistema de 
gerência. Entretanto, há uma estrutura organizacional mínima necessária para que cada um destes sistemas possa funcionar de forma adequada, que é, de acordo com Hass, Hudson e Zaniewski (1994), a seguinte:

i. Inventário: descrição e identificação das seções; classificação funcional e administrativa características estruturais do pavimento; dados históricos (custos, tráfego, geometria...);

ii. Avaliação da condição atual: obtida por meio da ponderação dos defeitos encontrados na superfície do pavimento (irregularidade longitudinal, condição estrutural, condição de atrito...);

iii. Estratégias: baseadas na avaliação da condição de cada trecho do pavimento e nas causas de sua deterioração são estabelecidas estratégias de intervenção para que a condição do pavimento se mantenha acima do mínimo aceitável. Essas estratégias podem ser divididas em manutenção preventiva, manutenção corretiva, reabilitação e reconstrução. A tomada de decisão é baseada na análise dos defeitos ao longo do tempo, permitindo a análise dos custos e benefícios presentes e futuros;

iv. Necessidades: definida com base nos custos médios das ações de intervenção previstas e o volume de serviços fornecidos pelo inventário;

v. Prioridades: definidas quando os recursos não são suficientes para atender todas as necessidades;

vi. Programas: abrangem as intervenções feitas para atender as necessidades presentes e futuras;

vii. Orçamento: previsto a partir da estimativa de custos e seleção das estratégias. 


\subsection{ATIVIDADES DE MANUTENÇÃO E REABILITAÇÃO}

Para que um sistema de gerência de pavimentos seja eficiente, também devem ser eficientes as atividades por ele indicadas para conservação da qualidade da via, isso se reflete não somente por meio das intervenções, mas também que estas sejam feitas ao menor custo possível.

As intervenções passíveis de serem executadas são comumente divididas em manutenção (que pode ser de rotina, preventiva ou corretiva), reabilitação ou reconstrução. Todas elas visam reestabelecer as condições mínimas, adequadas ou iniciais da geometria e/ou da estrutura do pavimento.

A decisão de qual tipo de intervenção é a mais adequada em cada caso pode ser tomada com base em índices que representem a condição ou qualidade do pavimento ou mesmo a evolução de determinado defeito. Por isso, a concepção de índices de qualidade pode ser um fator chave em um sistema de gerência de pavimentos.

As estratégias de intervenções podem ser associadas ao que deve ser feito para adequação da qualidade da via férrea em cada caso.

i. Manutenção preventiva:

- Esmerilhamento do boleto;

- Substituição do trilho quanto a defeito de fabricação;

- Limpeza do lastro;

- Substituição de uma tala trincada, quebrada ou imprópria;

- Reposição ou aperto de um parafuso;

- Substituição de acessórios de fixação impróprios;

- Substituição de um dormente defeituoso que não se encontra na junta;

- Reposição de um dormente faltando;

- Reenquadramento de um dormente que não esteja na junta;

- Substituição de dois dormentes consecutivos defeituosos;

- Limpeza do lastro. 
ii. Manutenção corretiva:

- Substituição do trilho;

- Reperfilamento do trilho;

- Substituição do lastro;

- Reaperto de todos os parafusos;

- Reposição dos parafusos faltantes;

- Substituição de uma tala corroída, quebrada ou trincada no centro;

- Reaproximação de trilhos;

- Substituição de acessórios de fixação quebrados;

- Substituição de um dormente defeituoso que se encontra na junta;

- Reposição de dois dormentes faltando;

- Reenquadramento de um ou mais dormentes que não estejam na junta;

- Substituição de três dormentes consecutivos defeituosos;

- Limpar, socar e regularizar o lastro;

- Refazer a geometria.

iii. Reabilitação:

- Substituição do trilho;

- Refazer a solda;

- Substituição das duas talas de junção;

- Reposição de três dormentes faltando;

- Reenquadramento de um ou mais dormentes na junta;

- Substituição de quatro dormentes consecutivos defeituosos;

- Limpar, socar, desguarnecer e regularizar o lastro;

- Refazer a geometria.

iv. Reconstrução:

- Substituição do trilho e verificação de perfis maiores;

- Substituição de todos os parafusos;

- Substituição das duas talas de junção;

- Reaproximação de trilhos;

- Substituição dos acessórios de fixação e verificação de mudança no tipo; 
- Substituir cinco ou mais dormentes consecutivos;

- Substituir o lastro;

- Refazer a geometria e verificar possíveis mudanças no traçado.

Pantigoso (1998) propõe árvores de decisão para seleção de atividades de manutenção e reabilitação em pavimentos asfálticos em função da severidade e do tráfego, que pode ser, dependendo do tipo de defeito, como: "não fazer nada", "capa selante", "lama asfáltica", "tratamento superficial", "selagem de trincas", "preenchimento de buracos", "remendo", "regularização", "drenagem", "reciclagem" "recapeamento", "reconstrução", "recomposição do acostamento" ou "aplicação de areia quente". A Figura 4.1 mostra como exemplo a árvore de decisão para trincas por fadiga.

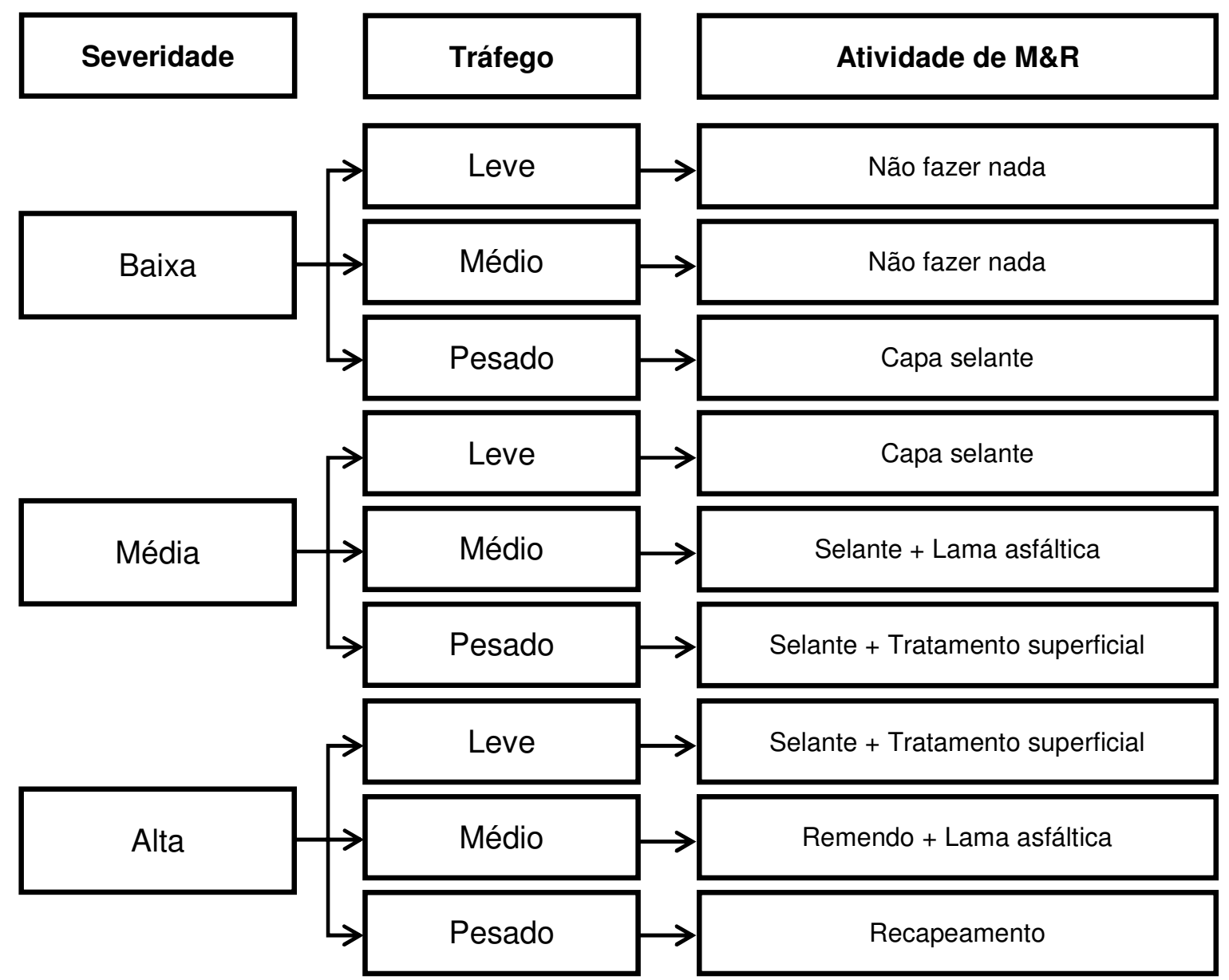

Figura 4.1. Árvore de decisão para o defeito trincas por fadiga (PANTIGOSO, 1998). 
O mesmo conceito pode ser usado nas estratégias de $M \& R$ de vias férreas. Dividindo-se os defeitos de acordo com o grupo que pertencem, podem-se determinar árvores de decisão em função de índices que representem a qualidade da via.

\subsection{MÉTODOS PARA AVALIAÇÃO DA CONDIÇÃO DO PAVIMENTO}

Existem diversos métodos de se avaliar a condição superficial do pavimento. Boa parte desses métodos leva em consideração três pontos em comum:

i. Tipo de defeito: há vários tipos de defeitos associados aos pavimentos e a correta determinação de cada um, ou a causa de sua ocorrência, é ponto fundamental em um sistema de gerência, pois implica em determinado procedimento das intervenções de M\&R;

ii. Severidade: reflete qual o estado de degradação em que se encontra o pavimento. A variação da severidade ao longo do tempo pode indicar a evolução de um dado defeito;

iii. Extensão: a extensão mostra o comprimento ou a área que o defeito ocupa. Um defeito com ampla extensão, mesmo que com baixa severidade, pode comprometer o pavimento, tanto estruturalmente, quanto funcionalmente. Alguns métodos de avaliação consideram, ao invés da extensão, a densidade de um defeito, que é a quantidade que esse defeito aparece por unidade de comprimento, área ou elemento da superestrutura.

Outra consideração que os métodos de avaliação apresentam é a divisão dos defeitos em classes ou grupos, de acordo com sua origem ou elemento da superestrutura que afetam. 
Ainda que não seja prática costumeira em todos os órgãos responsáveis, alguns métodos de gerência de pavimentos rodoviários e urbanos podem ser citados como mais adotados no Brasil:

\section{a) Procedimento DNIT-PRO 006/2003}

Trata do procedimento de avaliação objetiva da superfície de pavimentos flexíveis e semirrígidos. A condição do pavimento é dada em função da contagem e classificação dos defeitos aparentes, porém não considera a extensão dos defeitos.

Os defeitos são agrupados em classes, que recebem fatores de ponderação diferentes. Também são considerados fatores de ponderação em função da média e da variância das medidas das flechas geradas nas trilhas de roda interna e externa. Com isso é possível determinar o Índice de Gravidade Individual (IGI) em função da frequência relativa e do fator de ponderação, bem como o Índice de Gravidade Global (IGG), expressos nas Equações 4.1 e 4.2, respectivamente.

$$
\mathrm{IGI}=f_{r} \times f_{p}
$$

Em que:

$\mathrm{f}_{\mathrm{r}}=$ frequência relativa de cada defeito;

$\mathrm{fp}=$ fator de ponderação.

$$
\mathrm{IGG}=\sum I G I
$$

A classificação do pavimento em função do IGG é apresentada na Tabela 4.1. 
Tabela 4.1: Condição do pavimento em função do IGG.

\begin{tabular}{c|c}
\hline IGG & Condição do Pavimento \\
\hline $0-20$ & Boa \\
$21-80$ & Regular \\
$81-150$ & Ruim \\
$150-500$ & Péssima \\
\hline
\end{tabular}

\section{b) Procedimento DNIT-PRO 007/2003}

Este procedimento relata como deve ser executado o levantamento para avaliação da condição de superfície de subtrechos homogêneos de rodovias de pavimentos flexíveis e semirrígidos para a gerência de pavimentos, estudos e projetos.

As seções de análise são definidas por amostragem e o levantamento é feito por caminhamento em subtrechos de 100 metros cada, em segmentos homogêneos de 300 metros a 20 quilômetros. Os defeitos são anotados de forma a se conhecer o tipo, a severidade e a extensão em duas seções, de 6 metros cada, por subtrecho.

\section{c) Procedimento DNIT-PRO 008/2003}

O procedimento visa normatizar a avaliação de pavimentos flexíveis e semirrígidos pelo método do Levantamento Visual Contínuo (LVC).

O levantamento de defeitos é feito de dentro de um veículo que deve andar na velocidade média de $40 \mathrm{~km} / \mathrm{h}$ para todo o trecho a ser analisado. Os defeitos são anotados manualmente, assim como a extensão, para subtrechos que devem ter no mínimo 1 quilômetro e no máximo 6 quilômetros. Em casos especiais, como finais de trechos, o subtrecho pode ter menos de 1 quilômetro. 
À cada subtrecho, o avaliador deve atribuir uma nota que recebe o nome de Índice de Condição do Pavimento Flexível ou Semi-Rígido (ICPF), variando de 0 a 5, e que visa representar a necessidade de $M \& R$, em que 1 representa o pavimento em péssimas condições e 5 o pavimento em ótimas condições.

O Índice de Gravidade Global Expedito (IGGE) é determinado pela relação entre as frequências dos defeitos e os respectivos pesos (Equação 4.3).

$$
\operatorname{IGGE}=\left(P_{t} \times F_{t}\right)+\left(P_{\text {oap }} \times F_{\text {oap }}\right)+\left(P_{p r} \times F_{p r}\right)
$$

Em que:

$F_{t} ; P_{t}=$ frequência e peso do conjunto de trincas $t$;

$F_{\text {oap}} ; P_{\text {oap }}=$ frequência e peso do conjunto de deformações;

$\mathrm{F}_{\mathrm{pr}} ; \mathrm{P}_{\mathrm{pr}}=$ frequência e peso do conjunto de panelas e remendos.

O Índice do Estado de Superfície do Pavimento (IES), com nota variando de 0 a 10, é determinado em função da análise conjunta do ICPF e do IGGE (Tabela 4.2).

Tabela 4.2: Condição do pavimento em função do IES.

\begin{tabular}{c|c|c|c}
\hline Descrição & IES & Código & Conceito \\
\hline IGGE $\leq 20$ e ICPF $>3,5$ & 0 & A & Ótimo \\
\hline IGGE $\leq 20$ e ICPF $\leq 3,5$ & 1 & B & Bom \\
$20 \leq \mathrm{IGGE} \leq 40$ e ICPF $>3,5$ & 2 & & \\
\hline $20 \leq \mathrm{IGGE} \leq 40$ e ICPF $\leq 3,5$ & 3 & $\mathrm{C}$ & Regular \\
$40 \leq \mathrm{IGGE} \leq 60$ e ICPF $>2,5$ & 4 & & \\
\hline $40 \leq \mathrm{IGGE} \leq 60$ e ICPF $\leq 2,5$ & 5 & $\mathrm{D}$ & Ruim \\
$60 \leq \mathrm{IGGE} \leq 90$ e ICPF $>2,5$ & 7 & & \\
\hline $60 \leq \mathrm{IGGE} \leq 90$ e ICPF $\leq 2,5$ & 8 & \multirow{2}{*}{$\mathrm{E}$} & Péssimo \\
IGGE $>90$ & 10 & & \\
\hline
\end{tabular}

Fonte: DNIT-PRO 008/2003. 


\section{d) Manual do SHRP}

O manual foi desenvolvido pelo Programa Estratégico de Pesquisas Rodoviárias (Stratégic Highway Research Program - SHRP) para as pesquisas sobre o Desempenho de Pavimentos em Longo Prazo (Long-Term Pavement Performance LTPP) e contou com a participação de mais de 20 países, inclusive o Brasil. As pesquisas começaram no ano de 1987 com o intuito de continuarem por um período de 20 anos.

O manual descreve cada tipo de defeito que o pavimento está sujeito, bem como respectivas severidade e extensão, com o intuito de padronizar o levantamento de defeitos que servir como base para métodos de avaliação da condição superficial do pavimento.

e) Índice de Condição do Pavimento (ICP)

O método do Índice de Condição do Pavimento - ICP (ou no inglês, Pavement Condition Index $-\mathrm{PCl}$ ), foi desenvolvido pelo Laboratório do Corpo de Engenheiros do Exército Americano (USACERL), inicialmente para aeroportos, porém posteriormente aplicado também às ruas e rodovias.

Neste método, a superfície do pavimento é avaliada por meio de amostragem determinada estatisticamente (embora também permita uma análise contínua), em que são definidas as seções de análise. Nessas seções são identificados os tipos de defeitos, bem como suas severidades e extensões. O ICP é expresso pela Equação 4.4 .

$$
\mathrm{ICP}=100-\sum_{i=0}^{p} \sum_{j=0}^{m} a\left(T_{i} ; S_{j} ; D_{i j}\right) \cdot F(t ; q)
$$


Nesta equação, "ICP" é o índice de condição do pavimento, "a()" é o valor de ponderação dado em função de cada tipo de defeito, "T" os tipos de defeitos, "S" a severidade, "D" as densidades,"i" a quantidade de defeitos, "j" os níveis de severidade, "p" o número total de defeitos, "m" o número total de níveis de severidade e "F()" o fator de ponderação dado pelas curvas de ponderação.

Os Valores de Ponderação da Equação 3.4 variam de 0 a 100, em que 0 indica que o defeito não tem influência sobre a condição do pavimento e 100 indica que o defeito tem máxima importância na condição do pavimento. Para definir os valores de ponderação foram determinadas Curvas de Ponderação para cada tipo e severidade de defeitos possíveis de ocorrerem.

As curvas de ponderação foram construídas com base na avaliação de profissionais, com vasta experiência, que deram notas para cada tipo de defeito e respectivas severidade/extensão. Essa relação recebeu o nome de Avaliação da Condição do Pavimento - ACP (ou Pavement Condition Rating - PCR).

O método considera a interação de diversos tipos de defeitos, severidades e densidades dentro de um mesmo elemento da estrutura do pavimento e, para isso, os valores individuais dos defeitos são correlacionados com a soma dos valores de todos os defeitos individuais e, então, corrigidos por meio de Curvas de Correção.

Os resultados do ICP são relacionados à qualidade da via e permitem a comparação entre diversos pavimentos ou trechos diferentes de um pavimento (Tabela 4.3).

De acordo com Aps (2000), para vias urbanas, o método do PCI é o que apresenta melhores resultados e se mostrou mais consistente com relação à avaliação de defeitos e condições de conforto dos veículos ao rolamento. 
Tabela 4.3: Condição do pavimento em função do ICP.

\begin{tabular}{c|c}
\hline ICP & Condição do Pavimento \\
\hline $86-100$ & Excelente \\
$71-85$ & Muito Boa \\
$56-70$ & Boa \\
$41-55$ & Regular \\
$26-40$ & Ruim \\
$11-25$ & Muito Ruim \\
$0-10$ & Péssima \\
\hline \multicolumn{2}{c}{ Fonte: Adaptado de SHAHIN e KHON (1979). }
\end{tabular}

Nas metodologias de gerência para pavimentos rodoviários já há consolidação de alguns conceitos ou preceitos que podem, em muitos dos casos, serem transplantados para a concepção de sistemas de gerência aplicados às vias férreas.

\subsection{SISTEMAS DE GERÊNCIA DE VIAS FÉRREAS}

A aplicação de sistemas de gerência nas ferrovias se encontra em uma realidade muito mais distante do que a encontrada nos pavimentos rodoviários. Entretanto, alguns pesquisadores têm direcionado seus esforços à formulação de métodos que permitam a avaliação e classificação das vias férreas de modo a permitir que as intervenções de M\&R possam ser programadas e executadas no melhor momento, gerando maior economia, conforto e segurança.

Bhaskar, Ranjendran e Sood (2010) implantaram em Nova Delhi, na Índia, um sistema de gerência com enfoque no controle geométrico de ferrovias. A coleta de dados foi feita com carro controle e foram medidos os inícios e finais de curvas, superelevação, rampas e pontes. Como complemento, analisaram, também, a qualidade das juntas e das soldas nos trilhos. 
A Canadian National Railway (CN, 2012) usa o conceito de seção homogênea advindo das rodovias para fazer análise em suas ferrovias. Os parâmetros estruturais controlados estão relacionados aos trilhos, dormentes e irregularidade e são confrontados com os dados geométricos obtidos via carro controle.

Nos Estados Unidos foi desenvolvido o Railroad Maintenance System (RAILER), como parte de um trabalho executado pelo Corpo de Engenheiros dos Estados Unidos (U.S. Army Construction Engineering Research Laboratory - USACERL), que é uma ferramenta de suporte à decisão que pode ser usado para avaliar os níveis de condição de ferrovias, determinar as manutenções e reabilitações necessárias e seus respectivos custos, estabelecer orçamentos e desenvolver planos de trabalhos anuais e no longo prazo. O programa permite a análise e classificação dos defeitos, assim como suas severidades e extensões com modelagem feita com base em curvas de ponderação e correção, como na determinação do ICP.

No Brasil prevalece o ciclo "quebra-repara" como quase única forma de intervenção para manutenção e reabilitação da superestrutura ferroviária. Isso muitas vezes faz com que o tráfego de trens seja interrompido ou que a velocidade máxima permitida nas vias seja reduzida, gerando grandes perdas em termos financeiros e de tempo.

Os sistemas de gerência concebidos às ferrovias têm, em comum, a análise da evolução da degradação da via férrea tanto por meio da condição geométrica, quanto pela estrutural, embora os defeitos possam estar associados à geometria e à estrutura de forma conjunta. Essa separação no estudo dos defeitos permite com que sejam criados modelos diferentes para análise da geometria e da estrutura e, por fim, facilitar a identificação de qual tipo de intervenção para a recuperação da qualidade da via é o mais adequado. 


\subsubsection{Análise geométrica}

\subsubsection{Conceito}

Para que se consiga manutenção adequada da via férrea, são necessárias inspeções constantes e regulares, as quais podem ser divididas basicamente em inspeções da geometria da via e inspeções estruturais da via. A primeira é realizada por meio de carros-controle que portam instrumentos eletrônicos capazes de medir e gravar alterações geométricas da via, sejam elas horizontal, vertical ou transversal; a segunda é conseguida por meio de inspeções visual por ou automatizada e, embora as inspeções estruturais automatizadas forneçam dados mais rapidamente, as inspeções visuais ainda são muito usadas e trazem ótimos resultados.

A geometria da via representa espacialmente onde se encontram os trilhos da via férrea e pode ser dividida de acordo com o plano de trabalho dos parâmetros envolvidos. De acordo com Sadeghi e Akbari (2006), os principais parâmetros que definem a geometria da via são a bitola (plano da via), o perfil (plano longitudinal), o alinhamento (plano horizontal), o nível cruzado e a torção (plano transversal). Entende-se por nível cruzado a diferença de nível existente entre as superfícies dos dois trilhos paralelos, ou seja, a superelevação encontrada nas curvas, com o intuito de compensar a ação da força centrífuga; não é considerado um defeito a menos que esteja fora dos limites impostos no projeto.

Com o intuito de se qualificar a condição da via espacialmente e quantificar os defeitos geométricos, se faz necessário a concepção de um índice que a represente numericamente, objeto deste capítulo.

\subsubsection{Classificações das ferrovias}

Os índices de geometria muitas vezes estão associados com as classes das ferrovias. Uma ferrovia com caráter técnico mais elevado, na qual percorram trens com maiores velocidades e tonelagens-brutas, requer padrão mais rigoroso no controle da qualidade. Por outro lado, ferrovias usadas para transportar baixas 
tonelagens anuais ou que conduzam trens mais lentos, permitem maiores folgas no seu controle geométrico.

As classes das vias férreas podem ser definidas em função da densidade do tráfego (em milhões de toneladas-brutas anuais - MTBA) e da velocidade de operação dos trens, de acordo com os valores sugeridos pela American Railway Engineering and Maintenance-of-Way Association (AREMA, 2006), apresentados na Tabela 4.4.

Tabela 4.4: Definição da classe da ferrovia.

\begin{tabular}{c|c|c|c|c}
\hline \multirow{2}{*}{$\begin{array}{c}\text { Densidade do Tráfego } \\
\text { (MTBA) }\end{array}$} & \multicolumn{4}{|c}{ Velocidade (km/h) } \\
\cline { 2 - 5 } & $\mathbf{1 6 0}$ & $\mathbf{1 2 0 - 1 6 0}$ & $\mathbf{8 0 - 1 2 0}$ & $<\mathbf{8 0}$ \\
\hline$>15$ & $\mathrm{~A}_{1}$ & $\mathrm{~B}_{1}$ & $\mathrm{C}_{1}$ & $\mathrm{D}_{1}$ \\
$10-15$ & $\mathrm{~A}_{2}$ & $\mathrm{~B}_{2}$ & $\mathrm{C}_{2}$ & $\mathrm{D}_{2}$ \\
$5-10$ & $\mathrm{~A}_{3}$ & $\mathrm{~B}_{3}$ & $\mathrm{C}_{3}$ & $\mathrm{D}_{3}$ \\
$<5$ & $\mathrm{~A}_{4}$ & $\mathrm{~B}_{4}$ & $\mathrm{C}_{4}$ & $\mathrm{D}_{4}$ \\
\hline
\end{tabular}

Fonte: Adaptado de AREMA (2006).

A Federal Railroad Administration (FRA, 2008) considera as diferentes classes das ferrovias somente de acordo com a velocidade máxima dos trens que nelas trafegam (Tabela 4.5).

Tabela 4.5: Classificação das ferrovias.

\begin{tabular}{c|c}
\hline Classe da Via & $\begin{array}{c}\text { Velocidade Máxima dos } \\
\text { Trens de Carga }(\mathbf{k m} / \mathbf{h})\end{array}$ \\
\hline 1 & 16 \\
2 & 40 \\
3 & 64 \\
4 & 97 \\
5 & 129 \\
\hline
\end{tabular}

Fonte: Adaptado de FRA (2008). 
A escolha da classe da ferrovia é ponto essencial para o início da formulação de índices de geometria, pois cada classe permite limites dispares para cada tipo de defeito geométrico encontrado na via.

\subsubsection{3 Índices e limites geométricos no mundo}

A importância de um índice que represente a geometria é de consenso mundial, porém não há consenso em que índice adotar, uma vez que diversos índices foram desenvolvidos em diferentes países. Segundo Ebersöhn e Conrad (2003), a Amtrak (empresa ferroviária estatal americana) desenvolveu, nos Estados Unidos, um índice que representa as irregularidades encontradas ao longo da ferrovia, calculado pela divisão da somatória dos quadrados dos desvios pelo número de pontos medidos (Equação 4.5).

$$
R^{2}=\sum_{i=1}^{n} \frac{d_{i}^{2}}{n}
$$

Nesta equação considera-se " $n$ " como sendo o número de medidas e "di" a quantidade de desvios na geometria medidos, considerando uma corda de 20 metros. Este índice é usado para estimar a qualidade do perfil, do alinhamento, do nível cruzado e da bitola.

Quanto menor for o valor de $\mathrm{R}^{2}$, melhor será a condição geométrica da via. A Amtrak considera a qualidade da via de acordo com a Tabela 4.6.

Tabela 4.6: Condição da via baseada no índice de irregularidade da Amtrak.

\begin{tabular}{c|c}
\hline Condição da Via & Valor de $\mathbf{R}^{2}$ \\
\hline Muito boa & $<1$ \\
Boa & 1 a 4 \\
Aceitável & 4,1 a 16 \\
Ruim & $>16$
\end{tabular}

Fonte: Adaptado de Ebersöhn e Conrad (2003). 
Ainda nos Estados Unidos, porém diferentemente da Amtrak, a Federal Railroad Administration (FRA) desenvolveu um índice de geometria focado no perfil vertical usando análises fractais, em um estudo realizado em aproximadamente 1 quilômetro de via. Nesse estudo, analisou-se a irregularidade de duas maneiras, a primeira associada à forma da via e a segunda à textura dos trilhos. As conclusões da pesquisa foram que os parâmetros calculados por meio de análises fractais caracterizaram adequadamente as condições de irregularidade da via (HYSLIP, TROSINO e SELIG, 2002). Segundo conclusões dos autores, a análise fractal é um bom indicador de irregularidade e é capaz de fornecer valores numéricos, em diferentes escalas, para caracterização geométrica da via. Outro ponto importante é que o método é capaz de comparar trechos com comprimentos diferentes, uma vez que seus indicadores numéricos são independentes de comprimentos. O método ainda possibilita estimar a contaminação do lastro e problemas com drenagem, embora os autores da pesquisa deixem claro que verificações de campo são essenciais para confirmar ou negar essas respostas nos locais onde o modelo identificou como problemáticos, ou seja, para qualidade do lastro e da drenagem, o método é apena indicativo.

A FRA também desenvolveu índices de qualidade da via (TQI - Track Quality Index) como complemento às normas de qualidade de via, com base na estimativa da soma das distâncias entre dois pontos consecutivos em segmentos de 85 metros, que representam perfil, alinhamento, nível cruzado e bitola, expressos na Equação 4.6 (ZHANG, EL-SIBAE e LEE, 2004).

$$
T Q I=\left[\frac{L_{s}}{L_{0}}-1\right] \cdot 10^{6}
$$

Sendo " $\mathrm{L}_{s}$ " o comprimento percorrido e " $\mathrm{L}_{0}$ " o comprimento que o segmento deveria ter.

De acordo com a FRA, o método é adequado para representar quantitativamente a qualidade da via. As tolerâncias impostas pelo método são apresentadas na Tabela 4.7. 
A Federal Railway Administration apresenta, ainda, valores de tolerância para a variação do alinhamento, considerando uma corda de 18,9 metros (Tabela 4.8).

Tabela 4.7: Tolerâncias definidas pelo método da FRA.

\begin{tabular}{c|c}
\hline Parâmetro & Limites \\
\hline Bitola & $-8 \mathrm{~mm}$ a $10 \mathrm{~mm}$ \\
Nível Cruzado & $-18 \mathrm{~mm}$ a $18 \mathrm{~mm}$ \\
Torção & $-3 \%$ a $3 \%$ \\
Irregularidade Horizontal & $-15 \mathrm{~mm}$ a $15 \mathrm{~mm}$ \\
Irregularidade Vertical & $-16 \mathrm{~mm}$ a $16 \mathrm{~mm}$ \\
\hline \multicolumn{2}{c}{ Fonte: Adaptado de Zhang, El-Sibae e Lee (2004). }
\end{tabular}

Tabela 4.8: Valores aceitáveis para diferenças de alinhamento pela FRA.

\begin{tabular}{c|c}
\hline Classe da Via & Variação do Alinhamento (mm) \\
\hline 1 & 127 \\
2 & 76 \\
3 & 44 \\
4 & 38 \\
5 & 16 \\
\hline
\end{tabular}

Fonte: Adaptado de Zhang, El-Sibae e Lee (2004).

O Manual de Engenharia Ferroviária Americano (AREMA, 2012) especifica valores de tolerância para diversos parâmetros geométricos de vias férreas. As Tabelas 4.9 a 4.13 apresentam os valores para bitola (variações negativas e positivas), alinhamento, perfil e torção, de acordo com a classe da via. Vale ressaltar que na Tabela 4.9 a única variação aceitável é na classe D1, o que indica a importância no controle desse parâmetro, independentemente da classe da via. 
Tabela 4.9: Tolerância em milímetros para desvios negativos de bitola.

\begin{tabular}{c|c|c|c|c}
\hline Classe da Via & A & B & C & D \\
\hline 1 & -1 & -1 & -1 & -2 \\
2 & -2 & -2 & -2 & -2 \\
3 & -4 & -4 & -4 & -4 \\
4 & -6 & -6 & -6 & -6 \\
\hline
\end{tabular}

Fonte: Adaptado de AREMA (2012).

Tabela 4.10: Tolerância em milímetros para desvios positivos de bitola.

\begin{tabular}{c|c|c|c|c}
\hline .Classe da Via & A & B & C & D \\
\hline 1 & +3 & +4 & +5 & +12 \\
2 & +6 & +8 & +10 & +12 \\
3 & +24 & +24 & +24 & +24 \\
4 & +35 & +35 & +35 & +35 \\
\hline \multicolumn{4}{r}{ Fonte: Adaptado de AREMA (2012). }
\end{tabular}

Tabela 4.11: Tolerância em milímetros para o alinhamento.

\begin{tabular}{c|c|c|c|c}
\hline Classe da Via & A & B & C & D \\
\hline 1 & \pm 2 & \pm 4 & \pm 6 & \pm 11 \\
2 & \pm 5 & \pm 8 & \pm 12 & \pm 21 \\
3 & \pm 9 & \pm 15 & \pm 24 & \pm 41 \\
4 & \pm 17 & \pm 29 & \pm 45 & \pm 50 \\
\hline
\end{tabular}

Fonte: Adaptado de AREMA (2012).

Tabela 4.12: Tolerância em milímetros para o perfil.

\begin{tabular}{c|c|c|c|c}
\hline Classe da Via & A & B & C & D \\
\hline 1 & \pm 6 & \pm 8 & \pm 12 & \pm 16 \\
2 & \pm 12 & \pm 16 & \pm 16 & \pm 18 \\
3 & \pm 20 & \pm 20 & \pm 20 & \pm 20 \\
4 & \pm 20 & \pm 20 & \pm 20 & \pm 20 \\
\hline
\end{tabular}

Fonte: Adaptado de AREMA (2012). 
Tabela 4.13: Tolerância em milímetros para torção.

\begin{tabular}{c|c|c|c|c}
\hline Classe da Via & A & B & C & D \\
\hline 1 & \pm 2 & \pm 3 & \pm 4 & \pm 8 \\
2 & \pm 5 & \pm 7 & \pm 9 & \pm 15 \\
3 & \pm 8 & \pm 13 & \pm 18 & \pm 24 \\
4 & \pm 15 & \pm 25 & \pm 28 & \pm 33 \\
\hline
\end{tabular}

Fonte: Adaptado de AREMA (2012).

Madejski e Grabozyk (2000) descrevem que, na Áustria, a Austrian Federal Railway usa cinco diferentes parâmetros para analisar os defeitos na via, calculados a partir de dados obtidos via carro controle. A deformidade medida para cada parâmetro, nos trechos analisados, é a relação da soma do comprimento das subseções que excederam o desvio aceitável com relação ao comprimento total da seção, de acordo com a Equação 4.7.

$$
w=\frac{\sum L_{i}}{L}
$$

Em que "Li" é o comprimento das subseções que excederam os valores aceitáveis de desvio e "L" é o comprimento total da seção de via.

Este modelo considera que um defeito não tem influência sobre outro, dessa forma a quantidade de defeitos pode ser expressa pela Equação 4.8.

$$
w_{5}=1-\left(1-w_{e}\right) \cdot\left(1-w_{g}\right) \cdot\left(1-w_{w}\right) \cdot\left(1-w_{y}\right) \cdot\left(1-w_{z}\right)
$$

Em que " $w_{z}$ " e " $w_{y}$ " são as médias aritméticas para as irregularidades vertical e horizontal, respectivamente, " $w_{g}$ " é a deformidade de nível cruzado, " $w_{w}$ " é a deformidade por torção, e " $w_{\mathrm{e}}$ " é a deformidade de bitola.

O método considera uma corda de 18,90 metros e a condição da via é escolhida conforme apresentado na Tabela 4.14. 
Tabela 4.14: Condição da via baseada nos valores de $\mathbf{w}_{5}$

\begin{tabular}{c|c}
\hline Condição da via & Valor de $\mathbf{w}_{\mathbf{5}}$ \\
\hline Nova & $<0,1$ \\
Boa & 0,1 a 0,2 \\
Regular & 0,2 a 0,66 \\
Ruim & $>0,6$ \\
\hline
\end{tabular}

Fonte: Adaptado de Madejski e Grabozyk (2000).

Madejski e Grabozyk (2000) concluíram que é necessário definir quais parâmetros (vertical, horizontal, torção, bitola e nível cruzado) influenciam na qualidade da viagem e que o conhecimento de cada um desses parâmetros é necessário para a análise da qualidade da via.

Na Austrália, a Rail Industry Safety and Standard Board (RISSB, 2001) recomenda limites geométricos para a bitola e para o alinhamento, considerando corda de 20 metros, conforme apresentado na Tabela 4.15.

Tabela 4.15: Tolerância em milímetros recomendada pela RISSB.

\begin{tabular}{c|c|c|c}
\hline Parâmetro & Tangente & Raios > 300 m & Raios < 300m \\
\hline Bitola & \pm 20 & \pm 20 & \pm 25 \\
Alinhamento & \pm 50 & \pm 50 & \pm 75 \\
\hline \multicolumn{3}{r}{ Fonte: Adaptado de RISSB (2001). }
\end{tabular}

Observa-se que curvas que tenham raio maior que 300 metros têm limites idênticos às tangentes.

A Indian Railway desenvolveu um Índice Global da Via (TGI - Track Global Index) que leva em conta diferentes parâmetros e avalia a condição da via entre os extremos "trecho novo" e "via necessitando urgentemente de manutenção" (MUNDREY, 2003). O índice para cada parâmetro individual é dado pela Equação 4.9. 
Sendo que UI representa a irregularidade, $\mathrm{Tl}$ a torção, Al o alinhamento e $\mathrm{Gl}$ a bitola; " $\mathrm{SD}_{\mathrm{m}}$ " é o desvio-padrão do parâmetro medido, " $\mathrm{SD}_{\mathrm{n}}$ " é o desvio-padrão para um trecho novo e "SD ${ }_{u}$ " é o desvio-padrão para um trecho necessitando urgentemente de manutenção. A Tabela 4.16 mostra os valores tabulados.

Tabela 4.16: Valores de SD.

\begin{tabular}{c|c|c|c|c}
\hline \multirow{2}{*}{ Parâmetro } & \multirow{2}{*}{$\begin{array}{c}\text { Corda } \\
(\mathbf{m})\end{array}$} & $\begin{array}{c}\text { SD, trecho } \\
\text { novo }(\mathbf{m m})\end{array}$ & $\begin{array}{c}\text { SD, manutenção urgente }(\mathbf{m m}) \\
\text { Velocidade } \\
\mathbf{1 0 5} \mathbf{~ k m} / \mathbf{h}\end{array}$ & $\begin{array}{c}\text { Velocidade } \\
<\mathbf{1 0 5} \mathbf{~ k m} / \mathbf{h}\end{array}$ \\
\hline Irregularidade & 9,6 & 2,5 & 6,2 & 7,2 \\
Torção & 3,6 & 1,8 & 3,8 & 4,2 \\
Bitola & - & 1,0 & 3,6 & 3,6 \\
Alinhamento & 7,2 & 1,5 & 3,0 & 3,0 \\
\hline
\end{tabular}

Fonte: Adaptado de Mundrey (2003).

Os parâmetros geométricos recebem pesos diferentes de acordo com a importância dada pelo método, sendo o índice geral (TGI) calculado com o uso da Equação 4.10.

$$
T G I=\frac{2 \cdot U I+T I+6 \cdot A I+G I}{10}
$$

A classificação da qualidade da via em função do TGl é apresentada na Tabela 4.17.

Tabela 4.17: Condição da via baseada nos valores de TGI.

\begin{tabular}{c|c}
\hline Condição da via & TGI \\
\hline Ótima & $<36$ \\
Boa & 36 a 50 \\
Regular & 50 a 80 \\
Ruim & $>80$ \\
\hline
\end{tabular}

Fonte: Adaptado de Mundrey (2003). 
Na Suécia, a rede ferroviária nacional usa o índice Q (Equação 4.11), baseado em análises estatísticas, para avaliar a condição da via (ANDERSSON, 2002).

$$
Q=150-100 \cdot\left(\frac{\sigma_{H}}{\sigma_{\text {Hlim }}}+2 \cdot \frac{\sigma_{S}}{\sigma_{\text {Slim }}}\right) / 3
$$

Sendo " $\sigma_{H}$ " a média dos desvios-padrão dos perfis esquerdo e direito; " $\sigma_{S}$ " a média dos desvios-padrão de nível cruzado, bitola e desvio horizontal; " $\sigma_{\text {Hlim" }}$ o valor permitido de " $\sigma_{H}$ " baseado na categoria da via; " $\sigma_{S l i m}$ " o valor permitido de " $\sigma_{S}$ " baseado na categoria da via. O resultado é expresso por quilômetro de via.

Na Polônia usa-se o índice J (Equação 4.12) para a determinação das condições geométricas da via (MADEJSKI e GRABOZYK, 2000).

$$
J=\frac{S_{z}+S_{y}+S_{w}+0,5 \cdot S_{e}}{3,5}
$$

Sendo " $\mathrm{S}$ " o desvio-padrão de irregularidades verticais; "Sy" o desvio-padrão de irregularidades horizontais; " $S_{w}$ " o desvio-padrão de torção; "S $S_{z}$ " o desvio-padrão de bitola. O método leva em conta uma corda de 10 metros. Os valores permitidos de $\mathrm{J}$ são apresentados na Tabela 4.18.

Tabela 4.18: Valores permitidos de velocidade em função do índice J.

\begin{tabular}{c|c}
\hline Velocidade (km/h) & J \\
\hline 30 & 12,0 \\
40 & 11,0 \\
90 & 6,2 \\
120 & 4,0 \\
160 & 2,0 \\
200 & 1,4 \\
\hline
\end{tabular}


Outros países da Europa e da Ásia também usam uma abordagem de análise através do desvio-padrão de parâmetros como bitola, perfil, alinhamento e nível cruzado, baseados em recomendações do European Railway Research Center, que definem trechos de 1000 metros e segmentos de 18,9 metros (ORE, 1981).

A Companhia Vale do Rio Doce, em seu Manual Técnico da Via Permanente (CVRD, 2009), recomenda limites para a variação máxima de bitola de $2 \mathrm{~mm}$ entre dormentes consecutivos, para velocidades acima de $60 \mathrm{~km} / \mathrm{h}$, e $3 \mathrm{~mm}$ para velocidades abaixo de $60 \mathrm{~km} / \mathrm{h}$.

Com relação ao empeno, ou seja, a avaliação da torção com uma corda de 20 metros, a CVRD recomenda os valores apresentados na Tabela 4.19. Já para nivelamento e alinhamento, a CVRD segue as recomendações limites da Association of American Railroads, apresentados na Tabele 4.20.

Tabela 4.19: Valores máximos para empeno.

\begin{tabular}{c|c|c}
\hline Velocidade (km/h) & Curva (mm) & Tangente (mm) \\
\hline 15 & 15 & 34 \\
20 & 11 & 26 \\
25 & 9 & 21 \\
30 & 7 & 17 \\
35 & 6 & 15 \\
40 & 5 & 13 \\
45 & 5 & 11 \\
50 & 4 & 10 \\
55 & 4 & 9 \\
60 & 4 & 9 \\
65 & 3 & 8 \\
70 & 3 & 7 \\
\hline \multicolumn{2}{|c}{ Fonte: CVRD (2009). }
\end{tabular}


Tabela 4.20: Valores máximos para nivelamento e alinhamento.

\begin{tabular}{c|c|c}
\hline Parâmetro & Corda (m) & Limite (mm) \\
\hline Nivelamento & 40 & \pm 6 \\
Alinhamento & 40 & \pm 14 \\
\hline
\end{tabular}

Fonte: CVRD (2009).

\subsubsection{O RAILER e a análise estrutural}

\subsubsection{Conceito}

O Railroad Maintenance System (RAILER) é uma ferramenta de suporte à decisão que pode ser usado, em partes, para avaliar os níveis de condição de ferrovias, determinar as manutenções e reabilitações (M\&R) necessárias e seus respectivos custos, estabelecer orçamentos e desenvolver planos de trabalhos anuais e no longo prazo. Ele foi desenvolvido como parte de um trabalho executado pelo U.S. Army Construction Engineering Research Laboratory (USA-CERL), com o intento de prover a sua comunidade técnica com métodos de abordagem compreensíveis e sistemáticos de gerência e manutenção de ferrovias, permitindo uma gestão eficaz e eficiente de seus trechos ferroviários, através de procedimentos sistemáticos, de tal forma que as partes críticas da rede fossem mantidas em condições ideais com menor custo possível. Este trabalho foi desenvolvido inicialmente com a implantação de normas de gerência de ferrovias, que incluíam inspeção de elementos, frequência e procedimentos. O RAILER veio para concentrar essas normas em um programa computacional que tornasse mais fácil e prático executá-las.

Muitas das tarefas de suporte à decisão são concebidas para executar a análise da condição de trechos e determinar suas necessidades de M\&R de forma qualitativa e quantitativa, a partir de inspeções realizadas nos trechos. Entretanto, há diferentes intervenções de gerência passíveis de serem executadas, dependendo das informações da inspeção de via, não necessariamente requerendo o mesmo detalhamento. O RAILER prevê isso fazendo uso de três níveis de inspeção, que são associados com segurança, gerência em nível de rede e de projeto. 
A gerência em nível de segurança da via é uma parte crítica de um sistema de gerência de ferrovia, por isso um programa de segurança é normalmente exigido e regido por normas, as quais especificam a frequência das inspeções nos trechos, com o propósito inicial de detectar defeitos ou outros problemas que, se existirem, resultam em níveis de classificação que podem restringir operações. As restrições geralmente vêem na forma de imposição de limites de velocidade até que o defeito ou problema seja corrigido, prejudicando assim, o escoamento de bens e serviços e o transporte de pessoas na via.

Várias inspeções de segurança podem ser realizadas durante o ano, dependendo do tipo de operação e importância do trecho, embora não sejam muito detalhadas por serem executadas de forma expedita. A elevação da segurança de uma via pode ser requerida com urgência se o trecho for de suma importância, o que implica em intervenções não planejadas. Caso velocidades operacionais mais baixas possam ser toleradas, as correções das deficiências de segurança podem ser adiadas, para incorporação em um sistema de M\&R planejado.

\subsubsection{Inspeções}

O RAILER foi desenvolvido de forma que seus projetos sejam capazes de identificar todos os tipos de defeitos especificados pela norma TM 5-628 (Army Railroad Track Standards), embora com ligeira modificação, para que os procedimentos de inspeções detalhadas fossem adaptados para uso com outras normas de avaliação de trechos, como as da Federal Railroad Andministration (FRA) e da Navy.

Os procedimentos de inspeção são detalhadamente divididos em sete áreas:
a) Inspeção de dormente;
b) Inspeção de trilho;
c) Inspeção de materiais de fixação e outros (F\&OTM);
d) Inspeção de lastro, subleito e via (BSR);
e) Inspeção de drenagem;
f) inspeção de aparelhos de mudança de via;
g) Inspeção geométrica. 
As inspeções primárias consistem de observação visual e medidas manuais específicas da estrutura do trecho, as quais podem ser facilitadas pela automatização na coleta de dados tanto da geometria do trecho quanto dos defeitos dos trilhos; já as inspeções regulares completas incluiriam as seis primeiras áreas. A inspeção manual da geometria da via normalmente é realizada somente quando houver indícios concretos de problemas potenciais.

\subsubsection{Inventário da malha}

O local da via e os procedimentos de identificação de seus componentes são particularmente importantes. Outros tipos de informação do inventário como comprimento do trilho, espaçamento entre dormentes etc., são usados quando os dados de inspeção são posteriormente processados no computador.

O procedimento tradicional é localizar os componentes e defeitos da via. A unidade comumente utilizada é o quilômetro mais a quantidade de metros (p. ex. 50+300). Cada trecho da via é dividido em um ou mais segmentos - que é a unidade básica dentro do programa RAILER - e os assimila a um número de identificação único. Os aparelhos de mudança de via e a identificação das curvas também são usados, bem como os componentes da área de geometria da via.

\subsubsection{Atividades de pré-inspeção}

Antes de se iniciar a inspeção dos trechos, três etapas precisam ser vencidas: especificação do grupo de inspeção definição das diretrizes gerais de cada membro; criação de um plano de inspeção para minimizar o tempo e esforço perdidos; obter e distribuir o equipamento.

\section{a) Grupo de inspeção}

O grupo de inspeção tem a função de realizar a inspeção visual detalhada do trecho, fazer medidas específicas dos componentes e marcar os componentes que necessitem eventualmente de reparos. 


\section{b) Plano de inspeção}

O plano de inspeção indica em que ordem os componentes e segmentos de trechos serão analisados. Pode-se, por exemplo, analisar um componente ou determinado grupo de componentes quando da inspeção em um sentido e outro componente ou grupo de componentes na direção oposta, feita no retorno da equipe de inspeção no determinado trecho.

\section{c) Equipamento de inspeção}

Os equipamentos de inspeção podem ser divididos em grupos, sendo o primeiro deles os equipamentos de medição e contagem de defeitos; um segundo grupo inclui os equipamentos para gravar as medidas e defeitos; já o último grupo inclui os equipamentos para fazer as marcações apropriadas nos locais onde os defeitos se encontram.

\subsubsection{5 Índices de condição}

Os índices de condição devem ser capazes de medir objetivamente e quantitativamente a condição geral de cada segmento ou trecho da ferrovia, bem como serem capazes de ajudar na tomada de decisão de M\&R necessárias nas categorias básicas, no desenvolvimento de planos de trabalho, medir a eficácia do trabalho, estabelecer taxas de deterioração, fazer projeções de condição da via e priorizar o trabalho de M\&R.

O RAILER permite a determinação de índices para trilhos, juntas e fixações (RJCl), para dormentes (TCl) e para lastro, subleito e demais elementos de via (BSCl). A compilação desses três índices fornece o Índice de Condição Geral da Estrutura (TSCI). O desenvolvimento desses índices seguiu os mesmos conceitos usados em outros índices, como o Índice de Condição de Pavimento (PCI). 


\subsection{Escala dos índices de condição}

A escala dos índices de condição foi desenvolvida de forma a prover medidas objetivas e quantitativas, facilitando a análise de condição das vias com linguagem e interpretação comuns entre os usuários.

A escala usada pelos índices do RAILER varia de 0 a 100 e é dividida em sete categorias de condição, como mostra a Figura 4.2. A Tabela 4.21 mostra a descrição pormenorizada de cada categoria usada na escala dos índices de condição.

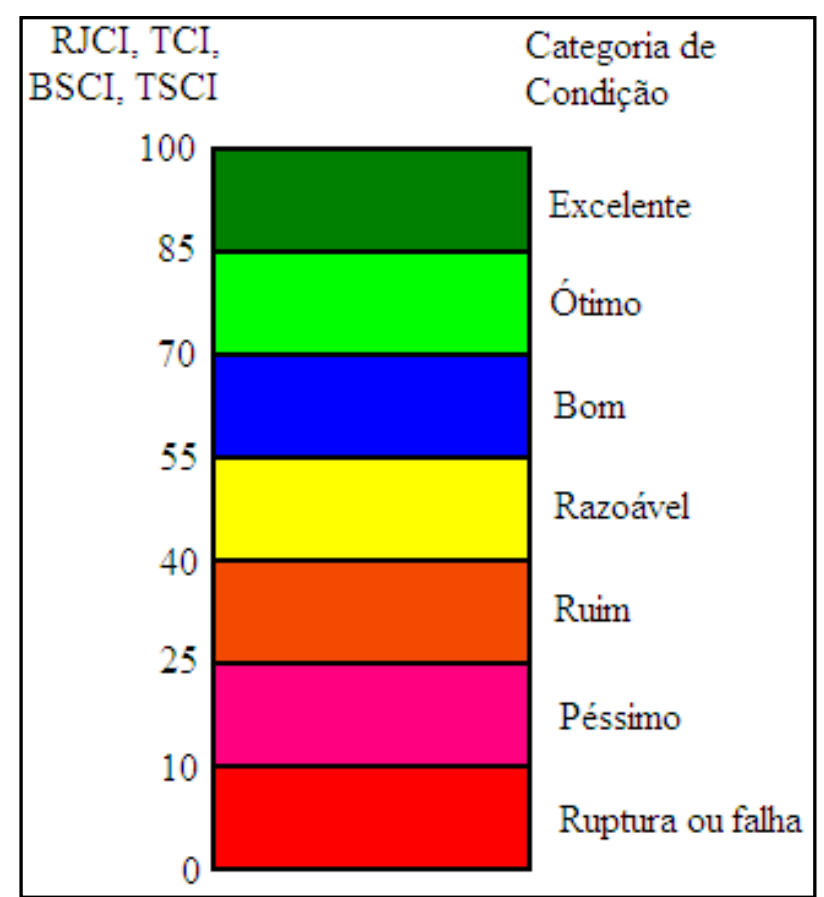

Figura 4.2: Escala dos índices de condição usada pelo RAILER. 
Tabela 4.21: Categorias da escala dos índices de condição.

\begin{tabular}{|c|c|c|}
\hline Índice & Categoria & Descrição da condição \\
\hline $86-100$ & Excelente & $\begin{array}{l}\text { Poucos defeitos. Funcionalidade do trecho não } \\
\text { comprometida. Nenhuma ação imediata de } \\
\text { intervenção requerida. Manutenção de rotina ou } \\
\text { preventiva deve ser agendada para análise. }\end{array}$ \\
\hline $71-85$ & Ótimo & $\begin{array}{c}\text { Pouca deterioração. Funcionalidade do trecho não } \\
\text { comprometida. Manutenção de rotina ou preventiva } \\
\text { deve ser agendada para análise. }\end{array}$ \\
\hline $56-70$ & Bom & $\begin{array}{l}\text { Moderada deterioração. Funcionalidade do trecho } \\
\text { pode estar um pouco comprometida. Manutenção de } \\
\text { rotina e pequenos reparos podem ser necessários. }\end{array}$ \\
\hline $41-55$ & Razoável & $\begin{array}{l}\text { Significante deterioração. Funcionalidade do trecho } \\
\text { comprometida, porém não seriamente. Manutenção de } \\
\text { rotina e pequenos reparos são necessários. }\end{array}$ \\
\hline $26-40$ & Ruim & $\begin{array}{l}\text { Severa deterioração em pequena porcentagem do } \\
\text { trecho. Deteriorações com menos severidade podem } \\
\text { estar presente em outras partes do trecho. } \\
\text { Funcionalidade do trecho seriamente comprometida. } \\
\text { Reparos maiores são necessários. }\end{array}$ \\
\hline $11-25$ & Péssimo & $\begin{array}{l}\text { Deterioração crítica em grande porcentagem do } \\
\text { trecho. Deteriorações com menos severidade podem } \\
\text { estar presentes em outras partes do trecho. Trecho } \\
\text { com mal funcionamento. Reparos maiores, porém } \\
\text { menos que reconstrução são necessários. }\end{array}$ \\
\hline $0-10$ & $\begin{array}{l}\text { Ruptura ou } \\
\text { falha }\end{array}$ & $\begin{array}{l}\text { Deterioração extrema em todo ou quase todo o trecho. } \\
\text { Trecho não é mais funcional. Reparos maiores, } \\
\text { restauração completa ou reconstrução são } \\
\text { necessários. }\end{array}$ \\
\hline
\end{tabular}




\subsection{Modelo de dedução ponderada de densidade}

A coleta de dados pelo painel de avaliação não resulta, por si só, em índices de condição desejados. Por esse motivo, um modelo se faz necessário para traduzir as informações coletadas nas avaliações em campo para os índices de condição, ou seja, os índices de condição são modelos matemáticos gerados para estimar a média das avaliações subjetivas feitas por um grupo de avaliadores experientes.

O modelo utilizado pelo RAILER é o de dedução ponderada de densidade, juntamente com análise de regressão para gerar as curvas de dedução.

\section{i. Especificação de defeitos}

O grau de deterioração de um grupo de componentes (trilhos e juntas, dormentes, lastro, subleito e fixações) é função de três características específicas: tipos de defeitos; severidade dos defeitos; quantidade de defeitos (normalmente expresso em porcentagem). Cada uma dessas características influencia profundamente na determinação e quantificação do grupo de componentes e devem ser incluídas em um modelo matemático de índice de condição. A seguir, uma breve descrição das três características.

\section{a) Tipos de defeitos}

São definidos 25 tipos diferentes de defeitos no RAILER, sendo 6 para o grupo de componentes trilho, juntas e fixações, 8 para o componente dormente e 11 para o grupo de componentes lastro, sub-base e via.

\section{b) Severidade dos defeitos}

O RAILER permite que sejam definidos quatro níveis de severidade, como mostra a Tabela 4.22. 
Tabela 4.22: Descrição dos níveis de severidade.

\begin{tabular}{cc}
\hline Nível de severidade & Descrição \\
\hline Baixo $(\mathrm{L})$ & $\begin{array}{c}\text { Defeitos menores que não afetam as operações na via. } \\
\text { Manutenção de rotina pode ser agendada para análise. }\end{array}$ \\
\hline Médio $(\mathrm{M})$ & $\begin{array}{c}\text { Defeitos podem causar restrições de operação na via. } \\
\text { Manutenção deve ser agendada para análise. }\end{array}$ \\
\hline Alto $(\mathrm{H})$ & Defeitos que geralmente causam restrições de operação na \\
& via. Manutenção deve ser realizada para remover as \\
& restrições. \\
\hline Muito alto $(\mathrm{VH})$ & Defeitos que evitam operações ou colocam uma grave \\
& restrição de operação na via. Manutenção e reabilitação \\
devem ser realizadas para restaurar as operações.
\end{tabular}

Alguns dos defeitos não podem chegar ao nível de severidade muito alto, restringindo, assim, a operação em níveis de menor severidade; da mesma forma, para alguns tipos de defeitos nenhum nível de severidade se faz necessário, pois não existem níveis perceptíveis de influência na operação da via.

\section{c) Quantidade de defeitos}

Mesmo que um tipo de defeito não esteja com severidade elevada, ele pode causar sérias restrições de operação na via, pelo fato de ocorrer em grande quantidade em um mesmo trecho.

A quantidade de defeitos em um trecho normalmente é expressa em porcentagem, evidenciando sua densidade no referido trecho.

\section{ii. Desenvolvimento das curvas de dedução e correção}

As curvas de dedução e correção foram desenvolvidas para converter os dados de classificação para valores dedutíveis e então traçar uma curva desses valores contra um parâmetro adequado. Em todos os casos, os valores dedutíveis são simplesmente 100 menos a média de classificação dos valores. 


\section{a) $\underline{\text { Curvas de dedução }}$}

As curvas de dedução são criadas traçando-se as médias dos valores dedutíveis contra suas respectivas densidades para a combinação de cada tipo de defeito e nível de severidade.

A determinação das equações das curvas de dedução primária é feita por análise de regressão. Como a regressão é baseada somente na matemática, este método não é usado para se obter as curvas finais, uma vez que as curvas de dedução para um dado tipo de defeito formam uma família e, como tal, cestas tendências consistentes de uma família são esperadas. Um melhor ajuste nas curvas finais assegura que as tendências estão corretas e coerentes com os acontecimentos físicos. Muitas vezes as curvas de regressão e as curvas de melhor ajuste são muito similares e na maioria dos casos, idêntica.

A curva final de dedução é usada para computar os valores deduzidos para cada defeito individual.

\section{b) Curvas de correção}

As curvas de correção são traçadas com as médias dos valores dedutíveis (Valores Dedutíveis Corrigidos - CDV) contra a somatória total dos valores dedutíveis individuais que compõe a combinação de defeitos. O somatório total é chamado de Valor Total Dedutível (TDV). 



\section{MÉtodos e índices propostos $\quad 5$}

\subsection{FERROVIAS EM ESTUDO}

As ferrovias que serviram de base para a pesquisa estão situadas no norte do estado do Paraná e estão concedidas à America Latina Logística S.A. (ALL), constituindo parte da Malha Sul, que engloba as malhas do Paraná, Santa Catarina e Rio Grande do Sul (Figura 5.1). A ALL responde atualmente por cerca de 21 mil quilômetros de vias férreas do Brasil, ou seja, aproximadamente $70 \%$ da malha ferroviária nacional. Dentro da Malha Sul, foram separados os trechos correspondentes à Unidade de Produção Norte (UP Norte) e Unidade de Produção Centro (UP Centro), por possuírem um banco de dados históricos consistente.

A escolha desta malha se deu, também, por ser constituída somente de bitola métrica, enquanto que outros trechos compreendem, além da bitola métrica, a bitola larga $(1,60 \mathrm{~m})$ e a bitola mista $(1,00 \mathrm{~m}$ e 1,60 m). De acordo com a Pesquisa Ferroviária da Confederação Nacional dos Transportes (CNT, 2011), a malha ferroviária nacional é composta por bitola métrica em quase $80 \%$ de sua extensão. 


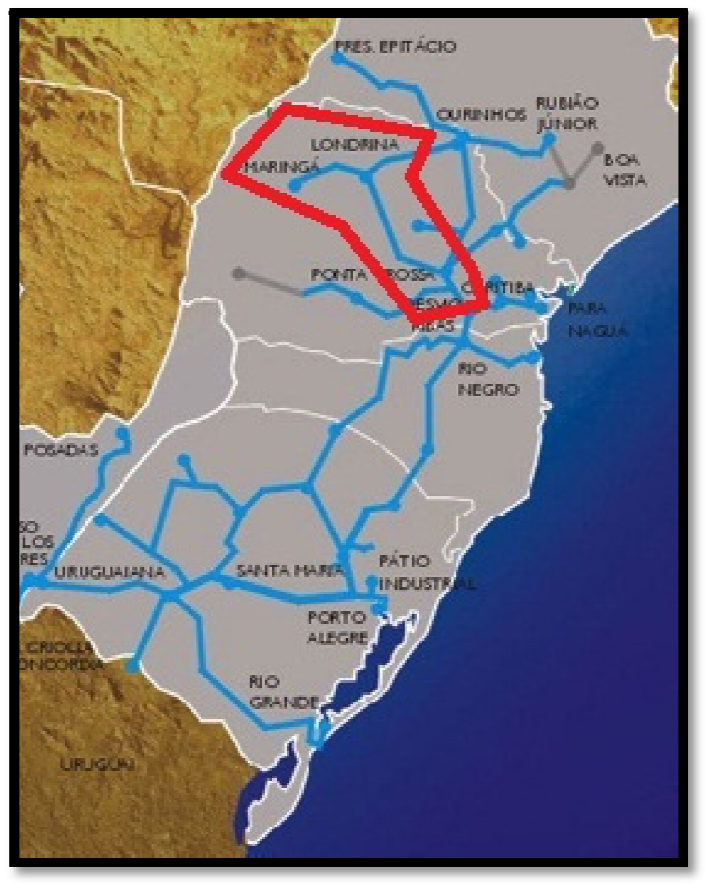

Figura 5.1: Malha Sul e trechos de estudo.

Para a concepção de índices que sejam representativos, se faz necessário definir de forma adequada quais foram os critérios adotados. Para esta pesquisa considerouse três critérios: (i) superestrutura da via; (ii) velocidade dos trens; (iii) quantidade de toneladas-brutas anualmente transportadas.

\subsubsection{Superestrutura}

A superestrutura considerada é composta por:

i. Lastro: de 30 centímetros de espessura. A espessura do lastro varia nos trechos estudados entre 25 e 35 centímetros aproximadamente, portanto foi escolhida a média simples como valor representativo para a pesquisa;

ii. Trilho: modelo TR-45. Quase a totalidade da via é composta por esse tipo de trilho. Há outros modelos, como TR-57 e TR-37, no entanto esses trechos foram descartados. Estruturas mais ou menos rígidas podem 
mascarar resultados estruturais, mesmo que a geometria não apresente problemas;

iii. Dormente: de madeira. O dormente de madeira é o utilizado em toda extensão do trecho. Também é o mais usado em todo o país;

iv. Fixações: rígidas (pregos e tirefonds) e flexíveis (tipo Deenik).

\subsubsection{Características do tráfego}

A velocidade máxima assumida para os trens que circulam nesse trecho é de $60 \mathrm{~km} / \mathrm{h}$ e não é necessariamente a limite, mas sim a que representa a média das velocidades máximas encontradas.

Nas ferrovias em estudo são transportadas de 800 mil a 1 milhão de toneladas brutas por mês no período de safra (abril a outubro) e metade desse valor no restante do ano, o que representa em torno de 7,2 a 9,0 milhões de toneladas brutas por ano (MTBA). A velocidade média dos trens não ultrapassa $80 \mathrm{~km} / \mathrm{h}$, desse modo, de acordo com a classificação da AREMA, a via se encontra na classe $D_{3}$.

A escolha dessas características de vias férreas pra formulação dos métodos engloba a realidade de quase a totalidade das ferrovias brasileira e, embora haja uma pequena parte de ferrovias não contempladas, os índices aqui propostos podem ser usados para essas vias que não se encontram dentro desses critérios, desde que apenas a título de comparação e estimativa de previsão de atividades de manutenção e reabilitação, bem como custos. 


\subsubsection{Manutenções no trecho}

Neste trecho são realizadas manutenções constantes e de forma cíclica, diminuindo o risco de se impor restrições de uso à via. A via trabalha sem fechamento desde que foi adotado esse critério de intervenções.

\subsection{MODELO GEOMÉTRICO}

Como um índice com base em distorções na localização espacial da via férrea pode ser um ótimo meio de avaliação da condição de ferrovias, buscou-se, neste trabalho, um parâmetro capaz de fornecer diretrizes para a caracterização das ferrovias brasileiras com base na análise de diferenças na bitola, no alinhamento, na torção e no empeno que são encontrados na superestrutura da via férrea.

\subsubsection{Coleta de dados}

A análise da geometria foi feita com base nos dados de alinhamento direito, alinhamento esquerdo, empeno, nivelamento direito, nivelamento esquerdo e bitola nos anos de 2008, 2009, 2010, 2011 e janeiro a julho de 2012. Para a inspeção e coleta de dados no trecho foi usado um carro controle da marca Plasser \& Theurer, modelo EM40 (Figuras 5.2 e 5.3).

A automação feita nesse veículo é capaz de coletar dados geométricos da via a cada 10 centímetros, com um comprimento de corda de 10 metros, o que totalizaria aproximadamente 58 milhões de pontos no trecho em estudo. A Figura 5.4 mostra um exemplo de como os dados são apresentados graficamente. 


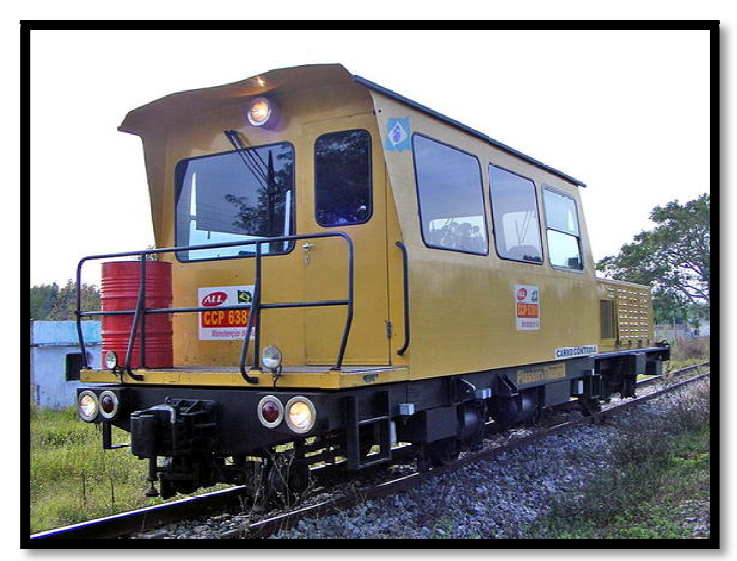

Figura 5.2. Carro controle - frente

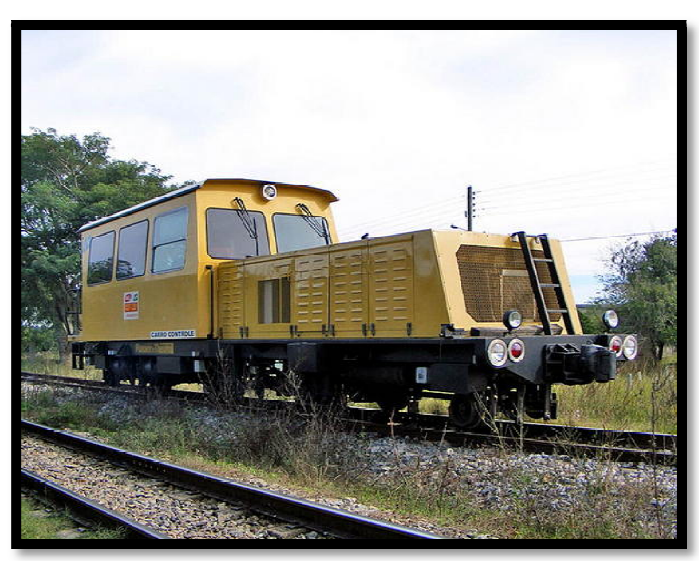

Figura 5.3. Carro controle - trás

Para reduzir a quantidade de dados coletados, foram definidos valores considerados como críticos, a partir dos quais houve gravação do parâmetro para posterior análise. A escolha destes valores foi feita não somente com base na literatura consultada, mas também - e principalmente - com referência aos valores que representaram problemas no trecho estudado ao longo dos anos. A Tabela 5.1 mostra os valores acima ou abaixo dos quais os dados referentes para cada parâmetro foram gravados.

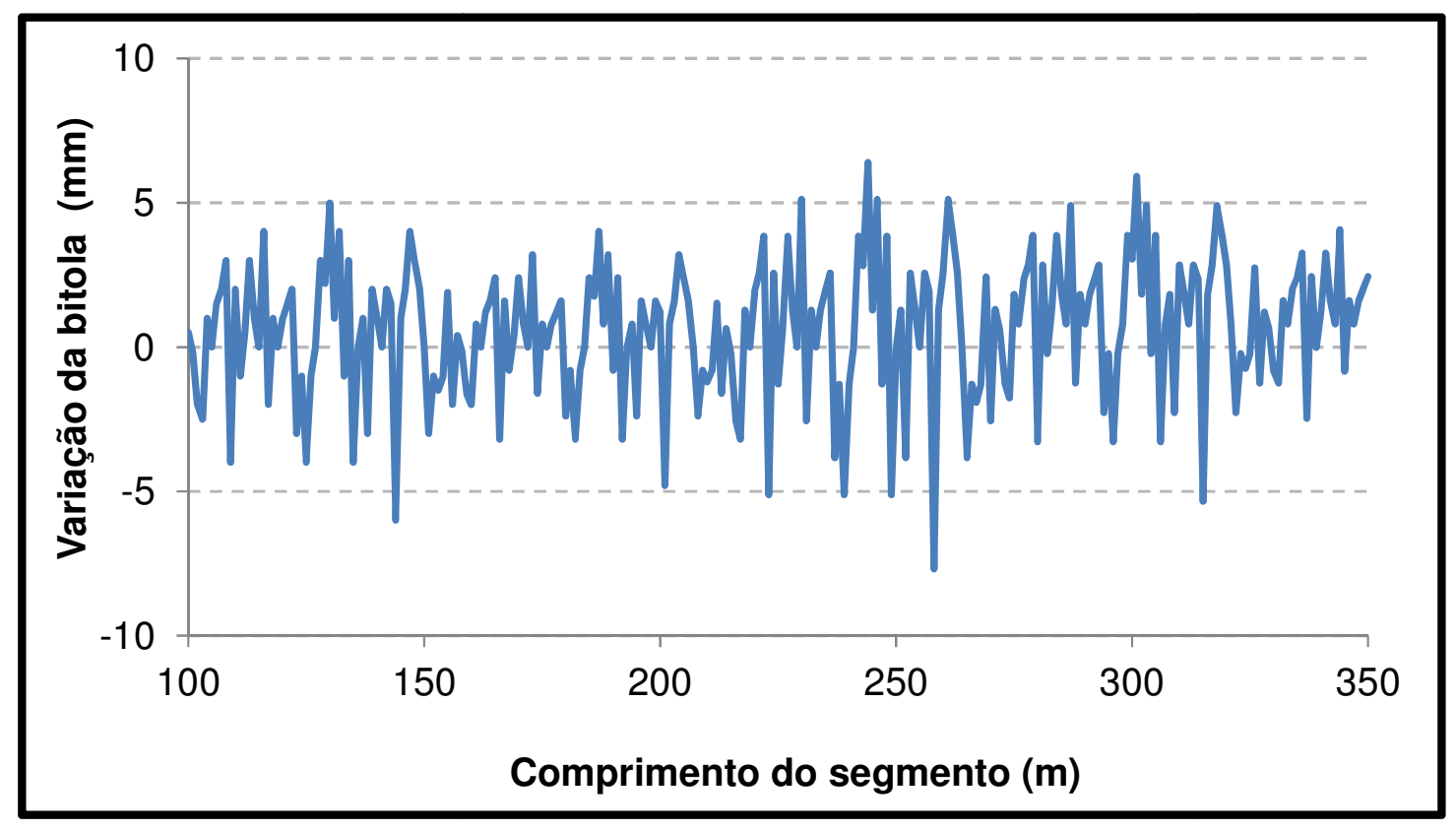

Figura 5.4: Dados de variação de bitola captados pelo carro controle. 
Tabela 5.1: Valores mínimos para coleta de dados.

\begin{tabular}{c|c}
\hline Parâmetro & Valor limite $(\mathbf{m m})$ \\
\hline Bitola & $>+20 \mathrm{e}<-5$ \\
Alinhamento & $>+20 \mathrm{e}<-20$ \\
Nivelamento & $>+6 \mathrm{e}<-6$ \\
Empeno & $>+5 \mathrm{e}<-5$ \\
\hline
\end{tabular}

\subsubsection{Análise dos dados}

Os trechos que se enquadraram nos valores apresentados na Tabela 5.1 foram definidos como defeituosos e, a partir deles, foram feitos os estudos estatísticos para formulação do índice geométrico de via. As Tabelas 5.2 a 5.6 apresentam as distribuições estatísticas para cada ano de análise. As três últimas colunas da direita mostram a quantidade de dados que se enquadram nos intervalos da média $\pm 1,2$ ou 3 vezes o respectivo desvio-padrão.

Tabela 5.2: Distribuição estatística dos trechos com defeito em 2008.

\begin{tabular}{c|c|c|c|c|c|c|c}
\hline Parâmetro & $\begin{array}{c}\text { Média } \\
\mathbf{( m m})\end{array}$ & $\begin{array}{c}\text { Desvio } \\
\text { Padrão } \\
(\mathbf{m m})\end{array}$ & $\begin{array}{c}\text { Valor } \\
\text { Máximo } \\
\mathbf{( m m})\end{array}$ & $\begin{array}{c}\text { Valor } \\
\text { Mínimo } \\
\mathbf{( m m})\end{array}$ & $\begin{array}{c}\text { Até } \\
\mathbf{1} \cdot \mathbf{D P} \\
\mathbf{( \% )}\end{array}$ & $\begin{array}{c}\text { Até } \\
\mathbf{2} \cdot \mathbf{D P} \\
\mathbf{( \% )}\end{array}$ & $\begin{array}{c}\text { Até } \\
\mathbf{3} \cdot \mathbf{D P} \\
\mathbf{( \% )}\end{array}$ \\
\hline Bitola negativa & $-0,7$ & 3,5 & $-29,8$ & -5 & 64,5 & 93,1 & 96,7 \\
\hline Bitola positiva & 2,7 & 2,5 & 44,3 & 20,0 & 65,1 & 95,3 & 98,6 \\
\hline Alinhamento esquerdo & $-8,9$ & 13,5 & 133,7 & $-117,2$ & 65,3 & 94,2 & 98,2 \\
\hline Alinhamento direito & $-0,3$ & 17,1 & 113,4 & $-98,7$ & 65,7 & 94,9 & 97,8 \\
\hline Nivelamento esquerdo & 1,5 & 13,5 & 182,2 & $-112,8$ & 66,8 & 95,6 & 98,1 \\
\hline Nivelamento direito & 4,5 & 14,6 & $-46,9$ & 43,6 & 66,5 & 95,7 & 99,3 \\
\hline Empeno & 0,1 & 7,9 & $-27,7$ & 26,1 & 66,4 & 95,1 & 98,8 \\
\hline
\end{tabular}


Tabela 5.3: Distribuição estatística dos trechos com defeito no ano de 2009.

\begin{tabular}{c|c|c|c|c|c|c|c}
\hline Parâmetro & $\begin{array}{c}\text { Média } \\
\mathbf{( m m})\end{array}$ & $\begin{array}{c}\text { Desvio } \\
\text { Padrão } \\
\mathbf{( m m})\end{array}$ & $\begin{array}{c}\text { Valor } \\
\text { Máximo } \\
\mathbf{( m m})\end{array}$ & $\begin{array}{c}\text { Valor } \\
\text { Mínimo } \\
(\mathbf{m m})\end{array}$ & $\begin{array}{c}\text { Até } \\
\mathbf{1} \cdot \mathbf{D P} \\
\mathbf{( \% )}\end{array}$ & $\begin{array}{c}\text { Até } \\
\mathbf{2} \cdot \mathbf{D P} \\
\mathbf{( \% )}\end{array}$ & $\begin{array}{c}\text { Até } \\
\mathbf{3} \cdot \mathbf{D P} \\
\mathbf{( \% )}\end{array}$ \\
\hline Bitola negativa & $-0,9$ & 3,6 & $-29,6$ & -5 & 65,2 & 93,9 & 99,2 \\
\hline Bitola positiva & 2,6 & 2,4 & 42,4 & 20 & 66,2 & 93,8 & 98,9 \\
\hline Alinhamento esquerdo & $-2,2$ & 21,5 & $-327,3$ & 165,3 & 66,1 & 94,5 & 99,3 \\
\hline Alinhamento direito & 1,2 & 16,5 & 255,6 & $-169,0$ & 66,5 & 94,8 & 99,6 \\
\hline Nivelamento esquerdo & $-2,5$ & 14,4 & $-158,9$ & 48,3 & 65,9 & 94,9 & 98,6 \\
\hline Nivelamento direito & $-6,6$ & 15,9 & $-184,6$ & 82,9 & 65,3 & 94,7 & 98,7 \\
\hline Empeno & 0,0 & 8,4 & 33,8 & $-25,6$ & 66,8 & 95,3 & 99,6 \\
\hline
\end{tabular}

Tabela 5.4: Distribuição estatística dos trechos com defeito em 2010.

\begin{tabular}{c|c|c|c|c|c|c|c}
\hline Parâmetro & $\begin{array}{c}\text { Média } \\
\mathbf{( m m})\end{array}$ & $\begin{array}{c}\text { Desvio } \\
\text { Padrão } \\
(\mathbf{m m})\end{array}$ & $\begin{array}{c}\text { Valor } \\
\text { Máximo } \\
(\mathbf{m m})\end{array}$ & $\begin{array}{c}\text { Valor } \\
\text { Mínimo } \\
\mathbf{( m m})\end{array}$ & $\begin{array}{c}\text { Até } \\
\mathbf{1} \cdot \mathbf{D P} \\
\mathbf{( \% )}\end{array}$ & $\begin{array}{c}\text { Até } \\
\mathbf{2} \cdot \mathbf{D P} \\
\mathbf{( \% )}\end{array}$ & $\begin{array}{c}\text { Até } \\
\mathbf{3} \cdot \mathbf{D P} \\
\mathbf{( \% )}\end{array}$ \\
\hline Bitola negativa & $-0,4$ & 3,6 & $-30,4$ & $-5,0$ & 62,8 & 93,4 & 98,9 \\
\hline Bitola positiva & 2,7 & 2,4 & 42,9 & 20,0 & 63,8 & 94,1 & 99,2 \\
\hline Alinhamento esquerdo & 7,0 & 14,1 & 71,2 & $-69,0$ & 67,1 & 96,8 & 99,5 \\
\hline Alinhamento direito & 4,6 & 16,4 & 96,8 & $-67,4$ & 67,3 & 96,4 & 99,7 \\
\hline Nivelamento esquerdo & $-1,8$ & 12,2 & $-109,5$ & 101,1 & 66,2 & 65,9 & 98,8 \\
\hline Nivelamento direito & $-12,5$ & 4,2 & $-33,2$ & 11,8 & 66,1 & 96,2 & 99,3 \\
\hline Empeno & 0,2 & 8,2 & 49,2 & $-30,6$ & 67,1 & 97,0 & 99,5 \\
\hline
\end{tabular}


Tabela 5.5: Distribuição estatística dos trechos com defeito em 2011.

\begin{tabular}{c|c|c|c|c|c|c|c}
\hline Parâmetro & $\begin{array}{c}\text { Média } \\
\mathbf{( m m})\end{array}$ & $\begin{array}{c}\text { Desvio } \\
\text { Padrão } \\
(\mathbf{m m})\end{array}$ & $\begin{array}{c}\text { Valor } \\
\text { Máximo } \\
\mathbf{( m m})\end{array}$ & $\begin{array}{c}\text { Valor } \\
\text { Mínimo } \\
\mathbf{( m m})\end{array}$ & $\begin{array}{c}\text { Até } \\
\mathbf{1} \cdot \mathbf{D P} \\
\mathbf{( \% )}\end{array}$ & $\begin{array}{c}\text { Até } \\
\mathbf{2} \cdot \mathbf{D P} \\
\mathbf{( \% )}\end{array}$ & $\begin{array}{c}\text { Até } \\
\text { 3 } \cdot \mathbf{D P} \\
\mathbf{( \% )}\end{array}$ \\
\hline Bitola negativa & $-0,5$ & 3,7 & $-31,7$ & $-5,0$ & 68,0 & 95,5 & 99,2 \\
\hline Bitola positiva & 2,2 & 2,2 & 41,6 & 20,0 & 66,4 & 94,1 & 98,7 \\
\hline $\begin{array}{c}\text { Alinhamento } \\
\text { esquerdo }\end{array}$ & $-3,2$ & 15,4 & 179,9 & $-125,5$ & 67,3 & 94,7 & 98,3 \\
\hline Alinhamento direito & 7,3 & 17,8 & $-104,0$ & 99,8 & 63,1 & 95,8 & 98,8 \\
\hline Nivelamento esquerdo & $-2,8$ & 14,0 & $-64,1$ & 43,7 & 65,9 & 95,7 & 98,0 \\
\hline Nivelamento direito & $-4,3$ & 13,9 & 71,3 & $-69,6$ & 65,3 & 95,1 & 97,9 \\
\hline Empeno & 0,4 & 9,1 & 39,4 & $-28,8$ & 66,8 & 97,1 & 99,4 \\
\hline
\end{tabular}

Tabela 5.6: Distribuição estatística dos trechos com defeito em 2012.

\begin{tabular}{c|c|c|c|c|c|c|c}
\hline Parâmetro & $\begin{array}{c}\text { Média } \\
\mathbf{( m m}\end{array}$ & $\begin{array}{c}\text { Desvio } \\
\text { Padrão } \\
\mathbf{( m m})\end{array}$ & $\begin{array}{c}\text { Valor } \\
\text { Máximo } \\
\mathbf{( m m})\end{array}$ & $\begin{array}{c}\text { Valor } \\
\text { Mínimo } \\
\mathbf{( m m})\end{array}$ & $\begin{array}{c}\text { Até } \\
\mathbf{1} \cdot \mathbf{D P} \\
\mathbf{( \% )}\end{array}$ & $\begin{array}{c}\text { Até } \\
\mathbf{2} \cdot \mathbf{D P} \\
\mathbf{( \% )}\end{array}$ & $\begin{array}{c}\text { Até } \\
\mathbf{3} \cdot \mathbf{D P} \\
\mathbf{( \% )}\end{array}$ \\
\hline Bitola negativa & $-0,3$ & 3,3 & $-38,4$ & $-5,0$ & 65,3 & 94,6 & 98,1 \\
\hline Bitola positiva & 2,8 & 2,8 & 49,7 & 20,0 & 66,8 & 94,5 & 98,9 \\
\hline Alinhamento esquerdo & 4,3 & 23,6 & 139,4 & $-68,9$ & 66,8 & 96,1 & 99,3 \\
\hline Alinhamento direito & 11,4 & 11,6 & 154,1 & $-140,3$ & 65,4 & 95,2 & 97,9 \\
\hline Nivelamento esquerdo & $-8,6$ & 17,2 & 323,4 & $-233,4$ & 65,9 & 94,9 & 98,5 \\
\hline Nivelamento direito & $-10,3$ & 11,3 & $-132,6$ & 51,6 & 66,1 & 95,0 & 97,6 \\
\hline Empeno & 0,2 & 8,8 & 30,0 & $-28,8$ & 67,8 & 95,3 & 99,6 \\
\hline
\end{tabular}

Analisando-se os dados apresentados nas Tabelas 5.2 a 5.6 percebe-se que, para todos os parâmetros avaliados, a maioria dos valores se encontra em torno da média $\pm 3 \cdot$ desvio-padrão e os pontos de inflexão se encontram na média \pm desvio- 
padrão, com indicação de que as curvas apresentam um padrão de distribuição normal (Figura 5.5) apresentado por Ott e Longnecker (2001).

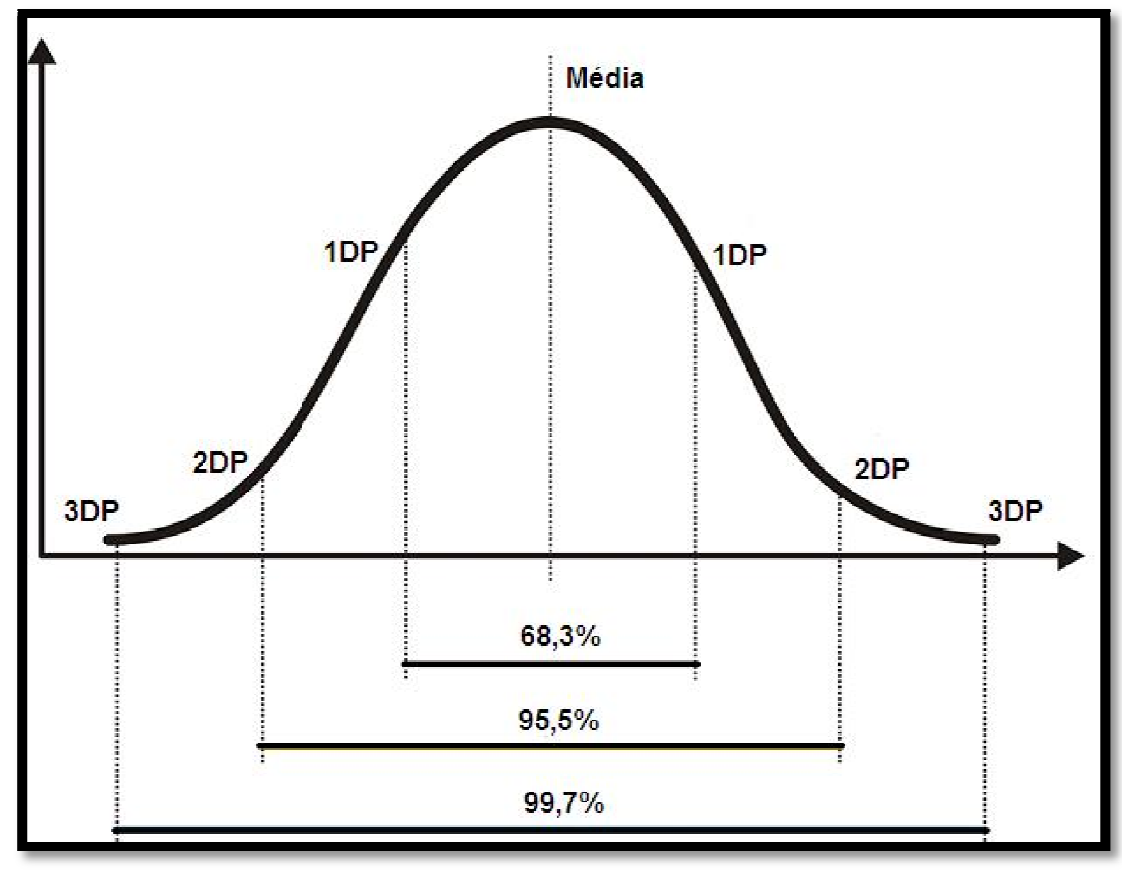

Figura 5.5. Curva normal padronizada.

Esse fato fica mais evidente com a comparação gráfica da curva normal padronizada com as curvas geradas com os dados da via, por exemplo, na variação de bitola no ano de 2008 (Figura 5.6). 


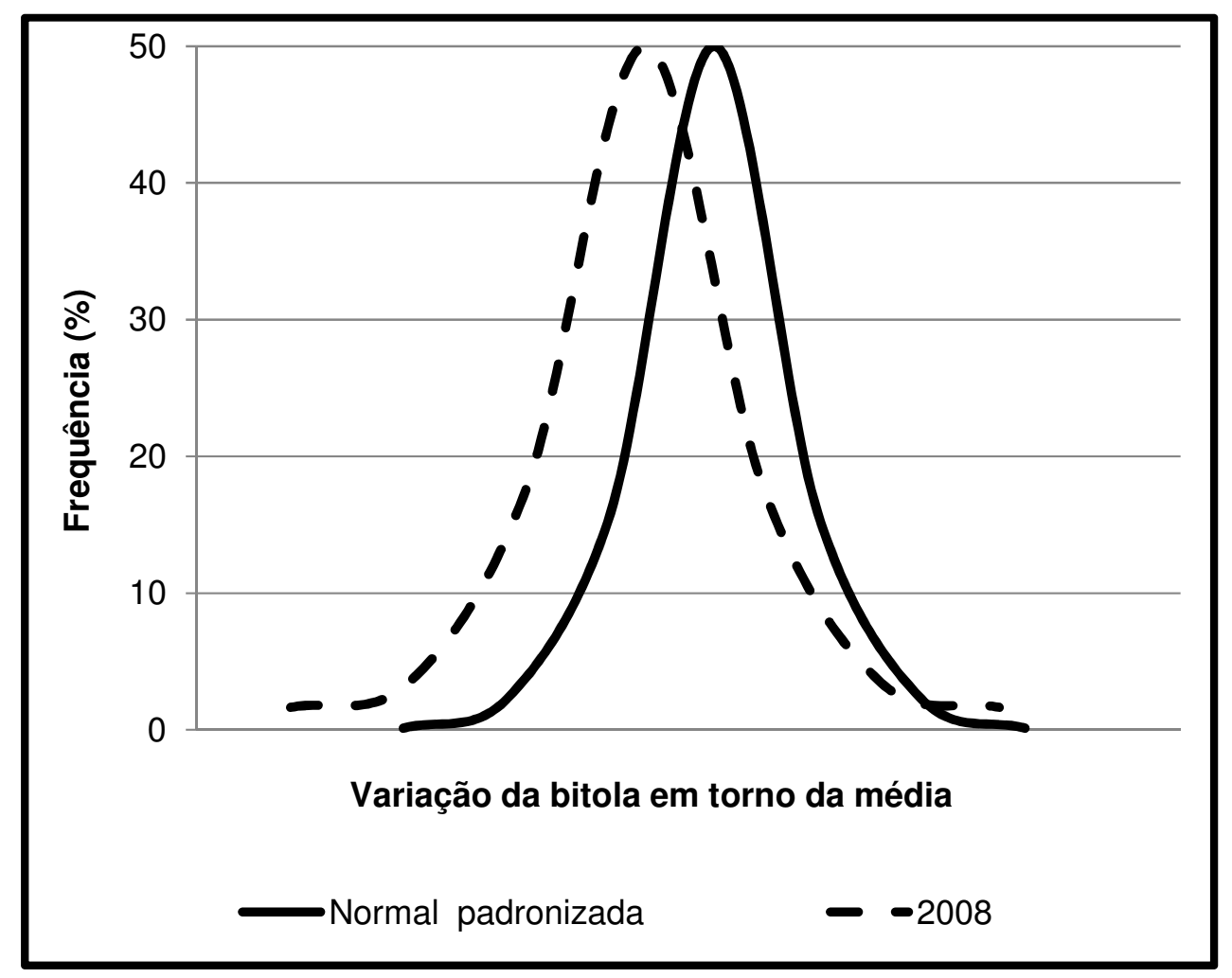

Figura 5.6: Distribuição da variação de bitola em 2008.

A Figura 5.7 mostra o comportamento dos parâmetros geométricos avaliados na pesquisa ao longo dos anos de 2008 a julho de 2012.

As médias das variações de bitola e empeno foram as mais constantes ao longo dos anos, uma vez que o controle desses parâmetros e as respectivas intervenções são feitos de forma mais rigorosa. As médias das variações no nivelamento e alinhamento apresentaram maiores oscilações, já que o controle técnico desses parâmetros não é tão rígido. 


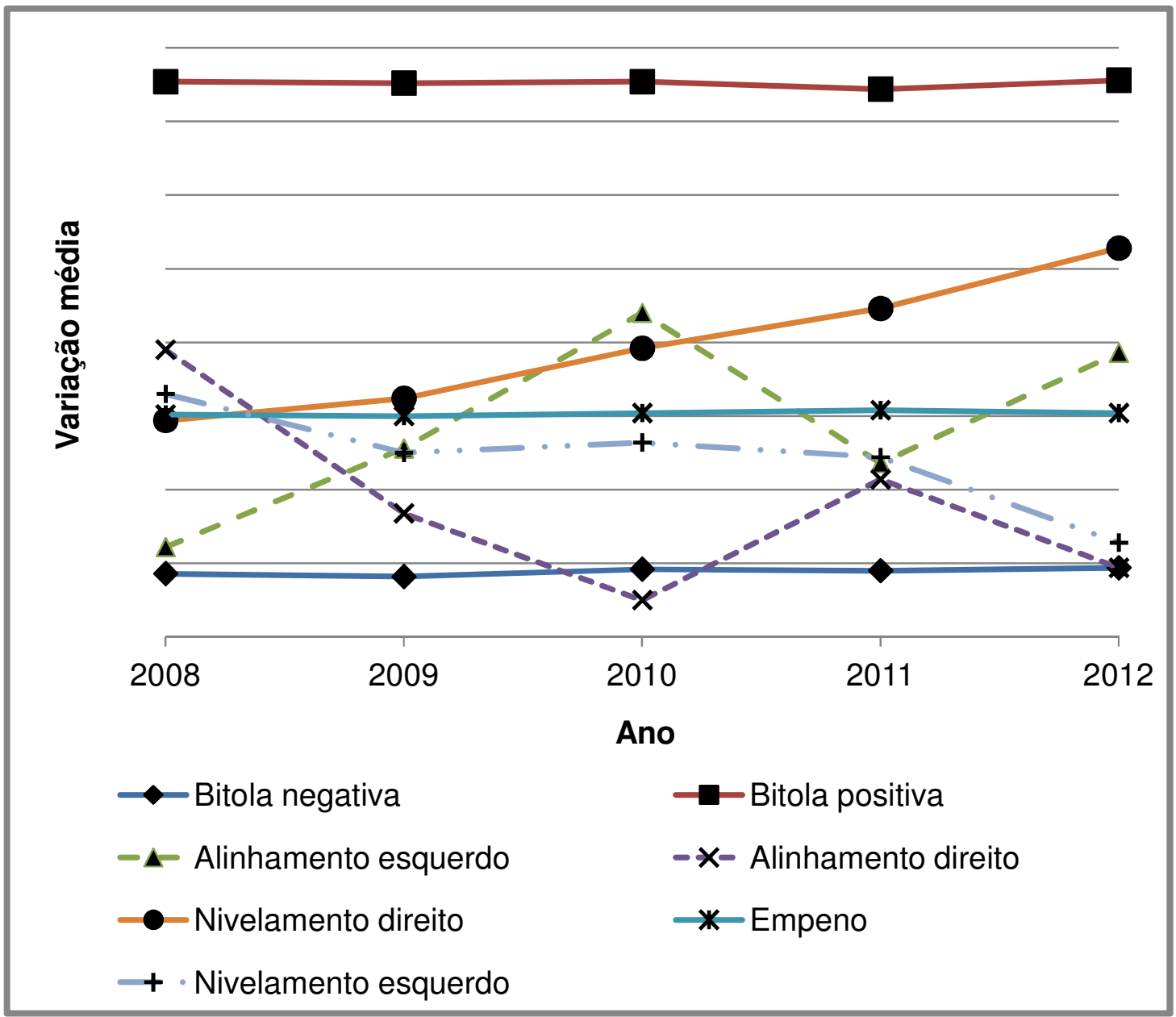

Figura 5.7: Comportamento ao longo dos anos dos parâmetros geométricos avaliados.

\subsubsection{Composição dos índices geométricos}

Considerando-se que a variação dos parâmetros analisados (bitola, alinhamento, nivelamento e empeno) apresenta comportamento semelhante a uma distribuição normal, tem-se que a quase totalidade dos defeitos se encaixa no intervalo da média mais ou menos três vezes o desvio-padrão. Dessa forma, definiu-se um índice base para cada parâmetro que represente estatisticamente todo o universo, expressos nas Equações 5.1 a 5.5 .

$$
I B B N=\left|\overline{B^{-}}-3 \cdot D P_{B^{-}}\right|
$$


Sendo:

$I B B N$ : Índice base de bitola negativa $(\mathrm{mm})$;

$\overline{B^{-}}$: Média dos valores de variação de bitola negativa no trecho analisado $(\mathrm{mm})$;

$D P_{B^{-}}$: Desvio-padrão dos valores de bitola negativa no trecho analisado $(\mathrm{mm})$.

$$
I B B P=\overline{B^{\overline{+}}}+3 \cdot D P_{B^{+}}
$$

Sendo:

$I B B P$ : Índice base de bitola positiva $(\mathrm{mm})$;

$\overline{B^{+}}$: Média dos valores de variação de bitola positiva no trecho analisado $(\mathrm{mm})$;

$D P_{B^{+}}$: Desvio-padrão dos valores de bitola positiva no trecho analisado $(\mathrm{mm})$.

$$
I B A=\frac{\left(\left|\overline{A_{E}}\right|+3 \cdot D P_{A E}\right)+\left(\left|\overline{A_{D}}\right|+3 \cdot D P_{A D}\right)}{2}
$$

Sendo:

IBA: Índice base de alinhamento $(\mathrm{mm})$;

$\bar{A}$ : Média dos valores de variação de alinhamento esquerdo ou direito no trecho analisado (mm);

$D P_{A E}$ : Desvio-padrão dos valores variação de alinhamento esquerdo no trecho analisado $(\mathrm{mm})$;

$D P_{A D}$ : Desvio-padrão dos valores variação de alinhamento direito no trecho analisado $(\mathrm{mm})$.

$$
I B N=\frac{\left(\left|\overline{N_{E}}\right|+3 \cdot D P_{N E}\right)+\left(\left|\overline{N_{D}}\right|+3 \cdot D P_{N D}\right)}{2}
$$

Sendo:

$I B N$ : Índice base de nivelamento $(\mathrm{mm})$;

$\bar{N}$ : Média dos valores de variação de nivelamento esquerdo ou direito no trecho analisado $(\mathrm{mm})$;

$D P_{N}$ : Desvio-padrão dos valores de variação de nivelamento direito ou esquerdo no trecho analisado $(\mathrm{mm})$. 


$$
I B E=\left|\bar{E}+3 \cdot D P_{E}\right|
$$

Sendo:

$I B E$ : Índice base de empeno $(\mathrm{mm})$;

$\bar{E}$ : Média dos valores de empeno no trecho analisado $(\mathrm{mm})$;

$D P_{E}$ : Desvio-padrão dos valores de empeno no trecho analisado $(\mathrm{mm})$.

A análise da densidade dos defeitos, em um determinado trecho, para cada parâmetro, pode ser feita dividindo-se a frequência de ocorrência dos defeitos pelo comprimento total do trecho (Equação 5.6).

$$
D_{i}=\frac{E_{D i}}{E_{T}} \cdot 100
$$

Sendo:

$D_{i}$ : Densidade de defeitos de bitola negativa ou positiva, nivelamento direito ou esquerdo, alinhamento direito ou esquerdo ou empeno (\%);

$E_{D i}$ : Extensão com defeitos (m);

$E_{T}$ : Extensão total do trecho $(\mathrm{m})$.

A qualidade geral de geometria da via é analisada considerando-se todos os parâmetros em conjunto. Para que a análise seja consistente, levou-se em conta que cada defeito tem determinada importância na composição do índice, atribuindose pesos diferentes para cada um.

A definição dos limites para cada defeito teve como base os valores recomendados pela AREMA (Tabelas 4.9 a 4.13). No entanto, os valores foram alterados de acordo com a realidade das ferrovias analisadas, com o intuito de limitar os valores em função dos problemas verificados nessas vias ao longo do período do estudo. 
A Tabela 5.7 mostra os valores limites para bitola negativa, bitola positiva, alinhamentos esquerdo e direito, nivelamentos esquerdo e direito e empeno adotados na formulação do método.

Tabela 5.7: Valores limites adotados.

\begin{tabular}{c|c}
\hline Parâmetro & Valor limite $(\mathbf{m m})$ \\
\hline Bitola negativa & -5 \\
Bitola positiva & +20 \\
Alinhamento & \pm 40 \\
Nivelamento & \pm 15 \\
Empeno & \pm 10 \\
\hline
\end{tabular}

Para a determinação do peso de cada defeito na análise da condição geométrica da via, levaram-se em conta os limites toleráveis para cada um, com base no parâmetro mais crítico. Assim, adotou-se como parâmetro mais crítico a bitola negativa, uma vez que a mesma permite menor tolerância nos valores, e calculou-se o peso dos outros defeitos pela relação entre os limites de cada um e o limite para a bitola negativa (Tabela 5.8).

Tabela 5.8: Pesos atribuídos para cada defeito.

\begin{tabular}{c|c|c}
\hline Parâmetro & Relação & Peso \\
\hline Bitola Negativa (bn) & 1,000 & 0,32 \\
Bitola Positiva (bp) & 0,250 & 0,08 \\
Alinhamento (a) & 0,125 & 0,08 \\
Nivelamento (n) & 0,333 & 0,21 \\
Empeno (e) & 0,500 & 0,31 \\
\hline
\end{tabular}

Em outras palavras, o valor com que cada defeito afeta a via (coluna "Relação" da Tabela 5.8) foi calculado dividindo-se o limite tolerável para bitola negativa pelo limite tolerável para cada um dos outros tipos de defeito. A influência de cada defeito na qualidade da via está expressa na coluna "Peso" da Tabela 5.8 e foi calculada 
dividindo-se cada valor individual da coluna "Relação" pela somatória dos valores individuais da mesma coluna.

Ponderados os defeitos dentro da análise geométrica da via, definiu-se o Índice Qualidade Geométrica (IQG) (Equação 5.7).

$$
I Q G=\frac{b n / 2 \cdot I B B N+{ }^{b p} / 2 \cdot I B B P+a \cdot I B A+n \cdot I B N+e \cdot I B E}{[(b n+b p) / 2]+a+n+e}
$$

Considerando-se os valores determinados com base na análise de defeitos das ferrovias estudadas e valores limites de 0 a 100, em que 0 é a pior qualidade e 100 a melhor, a Equação 5.7 pode ser expressa pela Equação 5.8:

$I Q G=100-5,695 \cdot(0,32 \cdot I B B N+0,08 \cdot I B B P+0,08 \cdot I B A+0,21 \cdot I B N+0,31 \cdot I B E)$ (Equação 5.8)

Levando-se em conta os valores admitidos na pesquisa, a faixa de trabalho da via deve estar entre $30 \leq \mathrm{IQG} \leq 100$.

Um índice geométrico deve ser capaz de permitir a análise da evolução dos defeitos, ou seja, a perda de qualidade da via ao longo do tempo, para que possam ser tomadas as decisões adequadas de manutenção e reabilitação. A concepção de uma escala faz-se, desse modo, necessária.

Tomando-se como base valores aceitáveis para a via logo após a construção, podese definir a faixa de valores dentro dos quais uma via pode ser considerada nova. $A$ Tabela 5.9 apresenta os valores propostos para esta situação. 
Tabela 5.9: Valores aceitáveis propostos para vias novas.

\begin{tabular}{c|c}
\hline Parâmetro & Valor Limite $(\mathbf{m m})$ \\
\hline Bitola Negativa & -2 \\
Bitola Positiva & +4 \\
Alinhamento & \pm 5 \\
Nivelamento & \pm 4 \\
Empeno & \pm 3 \\
\hline
\end{tabular}

Com o uso da Equação 5.8 e dos valores adotados na Tabela 5.9, pôde-se definir a faixa de valores nos quais a via é considerada muito boa entre $100 \geq I Q G \geq 80$.

Deve-se destacar que a via trabalhando com IQG até 30 significa que as condições normais de velocidade são permitidas. No entanto, se a via apresentar IQG abaixo de 30 não significa que a via deva ser fechada, pois há um limite até o qual a restrição de velocidade permite que a via continue em operação.

Considerando a velocidade máxima de $25 \mathrm{~km} / \mathrm{h}$ como sendo a velocidade de restrição, os valores limites de cada parâmetro avaliado na pesquisa foram adotados como sendo os de vias férreas de classe $\mathrm{D}_{4}$ (Tabela 5.10).

Tabela 5.10: Valores aceitáveis propostos com restrição de velocidade.

\begin{tabular}{c|c}
\hline Parâmetro & Valor limite $\mathbf{( m m})$ \\
\hline Bitola negativa & -6 \\
Bitola positiva & +35 \\
Alinhamento & \pm 50 \\
Nivelamento & \pm 17 \\
Empeno & \pm 17 \\
\hline
\end{tabular}

Considerando-se os valores da Tabela 5.10, tem-se que a via pode operar com restrição de velocidade quando apresentar IQG entre 0 e 30. Para valores negativos de IQG a via deve ser fechada até que os defeitos sejam reparados. 
Embora vias trabalhando com IQG até o mínimo de 30 estejam dentro dos limites aceitáveis, convém determinar um coeficiente de segurança que alerte quando a via está chegando à sua situação crítica, antes que ocorra a restrição de velocidade. Para esta pesquisa adotou-se um limite de $70 \%$ para os valores considerados na Tabela 5.7 como sendo o indicador de que a condição geométrica inicial da via precisa ser restaurada (Tabela 5.11).

Tabela 5.11: Valores de segurança propostos.

\begin{tabular}{c|c}
\hline Parâmetro & Valor Limite $(\mathbf{m m})$ \\
\hline Bitola Negativa & $-3,5$ \\
Bitola Positiva & 14 \\
Alinhamento & \pm 28 \\
Nivelamento & $\pm 10,5$ \\
Empeno & \pm 7 \\
\hline
\end{tabular}

Para os valores considerados como de segurança, neste método, tem-se que a via pode trabalhar em condições aceitáveis até o IQG de 50.

A partir dos valores encontrados para IQG com o uso da Equação 5.8 e os limites impostos para cada condição da via, foi possível estabelecer uma escala para a qualidade da via férrea (Figura 5.8 e Tabela 5.12). Ressalta-se que para valores negativos a via deve ser fechada para reparos urgentes. 


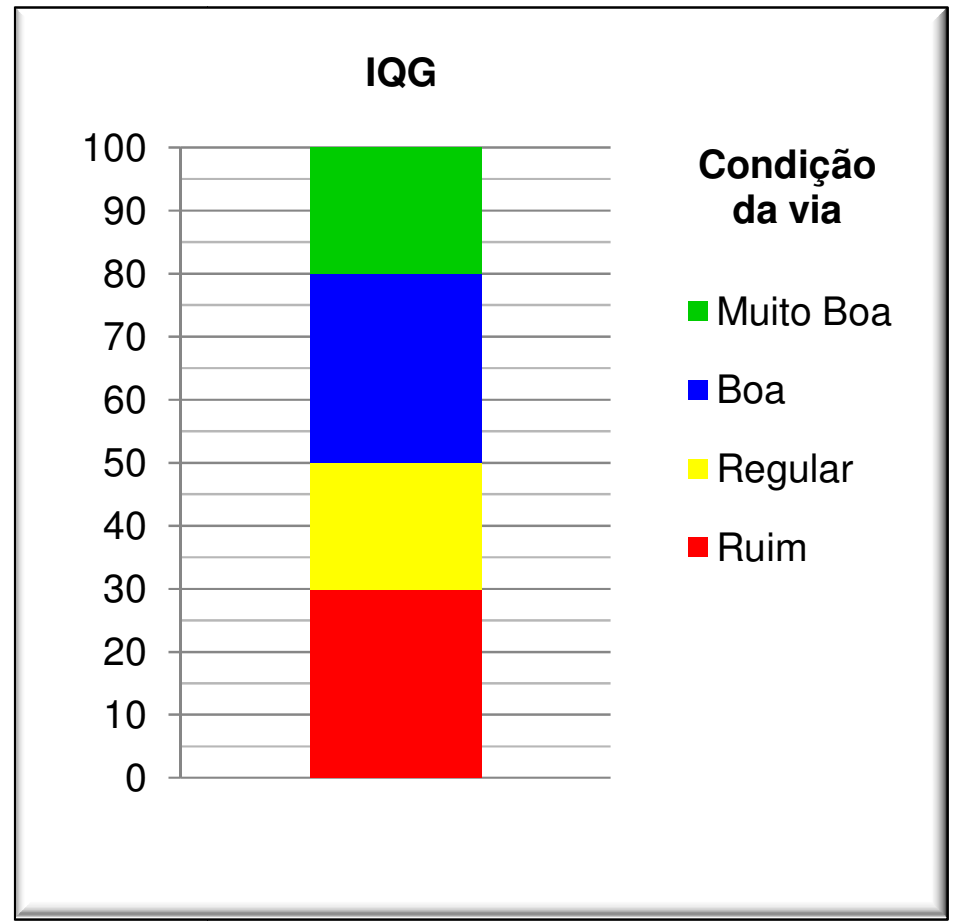

Figura 5.8: Condição da via em função do IQG.

Tabela 5.12: Valores limites usados no método.

\begin{tabular}{c|c}
\hline Condição da via & IQG \\
\hline Muito Boa & 80 a 100 \\
Boa & 50 a 80 \\
Regular & 30 a 50 \\
Ruim & 0 a 30 \\
Muito ruim & $<0$ \\
\hline
\end{tabular}

O IQG pode ser usado para a tomada de decisão das atividades de manutenção e reabilitação (M\&R) da via. A Tabela 5.13 apresenta as recomendações do método. 
Tabela 5.13: Atividades de $M \& R$ recomendadas.

\begin{tabular}{c|c|c}
\hline IQG & Condição da via & M\&R recomendada \\
\hline 80 a 100 & Muito boa & Nada a fazer \\
50 a 80 & Boa & Manutenção preventiva \\
30 a 50 & Regular & Manutenção corretiva \\
0 a 30 & Ruim & Reforço \\
$<0$ & Muito ruim & Reconstrução \\
\hline
\end{tabular}

\subsection{MODELOS ESTRUTURAIS}

A qualidade estrutural da via férrea - ou a quantidade e severidade dos defeitos que ela possui - reflete diretamente no custo, na qualidade e na segurança do transporte de cargas e pessoas. Todavia, a determinação ou estimativa dessa qualidade não é tão simples de ser mensurada.

Dois métodos podem ser usados para quantificar e qualificar os defeitos existentes em uma determinada ferrovia: método objetivo e método subjetivo. Ambos os métodos são eficazes, desde que corretamente modelados.

No método objetivo, os defeitos são mensurados e quantificados de forma objetiva com medidas e quantidades por um determinado comprimento de via. Já o método subjetivo procura estimar a quantidade e severidade dos defeitos por meio de avaliadores experientes que atribuem notas aos trechos analisados.

No uso de qualquer um dos dois métodos, somente a coleta de dados feita pelos avaliadores não dá como resposta a qualidade da via férrea. Para isso se faz necessária a determinação de índices que compilem esses dados e os exprimam de forma a classificar a via, normalmente em função de uma escala pré-determinada ou de limites aceitáveis. 
Os índices de condição devem ser capazes de medir adequadamente e quantitativamente a situação estrutural geral de cada segmento ou trecho da ferrovia, bem como serem capazes de ajudar na tomada de decisão das atividades de M\&R necessárias nas categorias básicas, no desenvolvimento de planos de trabalho, na medição da eficácia do trabalho, no estabelecimento de taxas de deterioração, nas projeções de condição da via e na priorização dos trabalhos de M\&R.

Neste capítulo são apresentadas propostas de índices que visam classificar a qualidade da via, tanto por um determinado grupo de defeitos, quanto de forma global, com base no procedimento para determinação do Pavement Condiction Index $(\mathrm{PCl})$ usado em rodovias e aeroportos.

\subsubsection{Caracterização do método}

O método está descrito em subitens, de forma não só a facilitar a compreensão, mas também direcionar os passos que devem ser seguidos na formulação ou aperfeiçoamento de índices de condição.

\subsubsection{Levantamentos de dados}

Os levantamentos de defeitos foram realizados nos anos de 2008, 2009, 2010, 2011

e janeiro a julho de 2012 de forma visual. A Tabela 5.1 apresenta um exemplo hipotético de como os dados foram registrados.

Na Tabela 5.1 são consideradas as seguintes colunas:

- Local: quilômetro inicial ou pontual do defeito;

- Ext.: extensão do defeito, dada em metros ou unidades;

- Tam.: tamanho do defeito, dado em milímetros ou unidades;

- Data: data de avaliação do defeito; 
- Loc.: localização do defeito (tangente - TG, curva - CV, trilho direito - TD, trilho esquerdo - TE);

- $\underline{\text { Conc.: }}$ conceito - nota dada de forma subjetiva pelo avaliador;

- Elemento: curva (cv) ou tangente (tg) e distância inicial e final em metros;

- Tipo de defeito: tipo de defeito encontrado.

A título de explicação da Tabela 5.14, considerando a primeira linha de dados, foi identificado um defeito de má qualidade de 2 malhas com 4 dormentes cada, no quilômetro 324 mais 100 metros, que se encontra em uma tangente com início no quilômetro 203 mais 340 metros e final no quilômetro 204 mais 205 metros, com peso dado de forma subjetiva pelo avaliador para severidade/extensão de 7 .

Tabela 5.14: Exemplo dos dados coletados.

\begin{tabular}{c|c|c|c|c|c|c|l}
\hline Local & Ext. & Tam. & Data & Loc. & Conc. & Elemento & Tipo de defeito \\
\hline 324,100 & 2 & 4 & $14 / 04 / 08$ & TG & 7 & $\begin{array}{c}203340- \\
204205 t g\end{array}$ & $\begin{array}{l}\text { DORMENTAÇÃO } \\
\text { MAU ESTADO } \\
\text { MALHA }\end{array}$ \\
\hline 326,900 & 1 & 13 & $14 / 04 / 08$ & CV TD & 3 & $\begin{array}{c}206530- \\
207880 \mathrm{cv}\end{array}$ & $\begin{array}{l}\text { JUNTA } \\
\text { DESNIVELADA }\end{array}$ \\
\hline 331,050 & 1 & 11 & $14 / 04 / 08$ & TG TE & 1 & $\begin{array}{c}210870- \\
211692 t g\end{array}$ & $\begin{array}{l}\text { JUNTA } \\
\text { DESNIVELADA }\end{array}$ \\
\hline 359,900 & 1 & 12 & $14 / 04 / 08$ & TG TE & 5 & $\begin{array}{c}239390- \\
241130 t g\end{array}$ & $\begin{array}{l}\text { JUNTA } \\
\text { DESNIVELADA }\end{array}$ \\
\hline 359,980 & 2 & 4 & $14 / 04 / 08$ & TG TD & 1 & $\begin{array}{c}239390- \\
241130 t g\end{array}$ & $\begin{array}{l}\text { DARMENTAÇÃO } \\
\text { MALHA ADO }\end{array}$ \\
\hline 361,480 & 1 & 10 & $14 / 04 / 08$ & CV TD & 6 & $\begin{array}{l}1 / 241130- \\
242050 \mathrm{cv}\end{array}$ & $\begin{array}{l}\text { JUNTA } \\
\text { DESNIVELADA }\end{array}$ \\
\hline 370,810 & 1 & 15 & $14 / 04 / 08$ & TG TE & 4 & $\begin{array}{c}250270- \\
250900 t g\end{array}$ & $\begin{array}{l}\text { TALA TRINCADA } \\
\text { NO MEIO }\end{array}$ \\
\hline 370,940 & 1 & 10 & $14 / 04 / 08$ & CV TE & 7 & $\begin{array}{c}250900- \\
251080 \mathrm{cv}\end{array}$ & $\begin{array}{l}\text { JUNTA } \\
\text { DESNIVELADA }\end{array}$ \\
\hline
\end{tabular}




\subsubsection{Tipos de defeitos}

Embora os defeitos estruturais aos quais as ferrovias estejam sujeitas possam ser divididos e subdivididos em diversos diferentes tipos (item 3.2 do Capítulo 3), nessa pesquisa foram considerados somente os que ocorrem com maior frequência nas ferrovias estudadas.

Com o intuito de se formular índices que analisem a ferrovia não somente de forma global, mas também por determinados conjuntos de defeitos em particular, optou-se por agrupar os defeitos como apresentados nos próximos subitens.

\subsubsection{Grupo de lastro}

Nesse grupo foi considerado somente o lastro e com defeito se:

- Contaminado.

\subsubsection{Grupo de dormente}

Cada dormente ou grupo de dormentes foram considerados como defeituosos se estivessem:

- Em mau estado de conservação;

- Mal posicionado (desenquadrado ou deslocado);

- Faltando.

\subsubsection{Grupo trilho, juntas e acessórios}

Os trilhos, as juntas e acessórios de fixação e de ligação foram considerados do mesmo grupo pelo fato que é esperado que se um problema de acessórios ou juntas ocorra, provavelmente um de trilho também ocorra, entretanto convém dividir e descrever os defeitos referentes a este grupo de acordo com o componente que ele pode afetar. 
i. Trilho:

- Desgaste;

- Trincado (na alma ou no patim);

- Trinca no boleto (horizontal, vertical, transversal);

- Trinca nos furos da junta.

ii. Ligação:

- Junta (aberta, desnivelada ou desgastada);

- Tala de junção (trincada ou faltando);

- Parafuso faltando.

iii. Fixação:

- Prego ou tirefond faltando;

- Placa de apoio quebrada.

\subsubsection{Níveis de severidade}

Simplesmente definir os tipos de defeito não é suficiente para a avaliação completa da via férrea, pois um mesmo defeito pode ter impacto diferente na qualidade da ferrovia dependendo do grau de deterioração que inflige à mesma.

O ideal é que quaisquer classificações tenham sempre um ponto central. Entretanto, para esta pesquisa foram definidos quatro níveis de severidade: baixa $(B)$, média $(M)$, alta (A), muito alta (MA), definidas da seguinte forma:

- Baixa: defeitos com baixa severidade, que não afetam as operações de tráfego e as atividades de manutenção recomendadas são acompanhamento e limpeza dos elementos da superestrutura. Este grau de severidade permite que as ações de manutenção sejam planejadas e executadas na melhor hora; 
- Média: defeito com média severidade que podem ou não comprometer o tráfego e gerar restrições. As intervenções para M\&R geralmente podem ser planejadas e agendadas;

- Alta: defeitos com severidade alta geralmente causam restrições no tráfego, sobretudo na velocidade limite. As atividades de M\&R devem ser executadas com rapidez para reestabelecer a condição adequada de tráfego dos trens;

- Muito alta: defeitos que se encontram com severidade muito alta e podem proibir a circulação de trens. As atividades de $M \& R$ não podem ser agendadas e devem ser executadas em caráter de urgência para que a via possa ser liberada ao tráfego novamente.

Poderia ter sido definido o nível de severidade "muito baixo", no entanto optou-se por desprezar os efeitos dos defeitos que estiverem com severidade abaixo do grau "baixo", uma vez que estes não afetam nem a estrutura e nem a geometria da via, como também não leva à substituição de qualquer parte da via férrea e a intervenção de M\&R seria "Nada a Fazer" para qualquer elemento.

Levando-se em conta que a severidade de nível baixo não acarreta em atividades restritivas de manutenção e reabilitação e normalmente é encontrada em vias novas ou em defeitos que não causam impactos significativos na qualidade das operações, pode-se considerar o nível de severidade alta como ponto central e os extremos como sendo os níveis de severidades média e muito alta.

Nem todos os tipos de defeitos podem apresentar todos os níveis de severidade, pois podem acarretar em interdição da via antes de atingirem os níveis de severidade mais elevados. Dessa forma, ficam os defeitos divididos de acordo com a severidade em:

i. Severidade baixa:

- Dormente mal posicionado (desenquadrado ou deslocado até $20 \mathrm{~cm}$ ); 
- Dormente em mau estado de conservação;

- Junta (aberta, desnivelada ou desgastada);

- Tala de junção trincada;

- Ligação com parafuso faltando;

- Trilho trincado superficialmente no boleto (horizontal, vertical, transversal).

ii. Severidade média:

- Dormente mal posicionado (desenquadrado ou deslocado mais do que $20 \mathrm{~cm}$ sem ser na junta);

- Dormente em mau estado de conservação;

- Junta (aberta, desnivelada ou desgastada);

- Tala de junção quebrada;

- Ligação com parafusos faltando;

- Trinca nos furos da junta $\leq 13 \mathrm{~mm}$;

- Trilho com trinca no boleto $\leq 5 \mathrm{~cm}$ (horizontal, vertical, transversal);

- Trilho desgastado;

- Trilho com trincas na alma ou no patim $\leq 13 \mathrm{~cm}$.

iii. Severidade alta:

- Dormente mal posicionado (desenquadrado ou deslocado mais do que $20 \mathrm{~cm}$ e na junta);

- Dormente em mau estado de conservação;

- Junta (aberta, desnivelada ou desgastada);

- As duas talas de junção trincadas;

- Trinca nos furos da junta $>13 \mathrm{~mm}$ e $\leq 38 \mathrm{~mm}$;

- Trilho com trincas no boleto $>5 \mathrm{~cm}$ e $\leq 10 \mathrm{~cm}$ (horizontal, vertical, transversal);

- Trilho desgastado;

- Trilho com trincas na alma ou no patim $>13 \mathrm{~cm} \mathrm{e} \leq 76 \mathrm{~cm}$. 
iv. Severidade muito alta:

- Dormente em mau estado de conservação;

- Junta (aberta, desnivelada ou desgastada);

- As duas talas de junção faltando ou quebradas;

- Ligação com todos os parafusos faltando;

- Trinca nos furos da junta $>38 \mathrm{~mm}$;

- Trilho com trinca no boleto $>10 \mathrm{~cm}$ (horizontal, vertical, transversal);

- Trilho com trincas na alma ou no patim $>76 \mathrm{~cm}$.

v. Sem divisão por níveis de severidade:

- Lastro contaminado;

- Dormente faltando;

- Placa de apoio quebrada;

- Fixação com prego ou tirefond faltando.

\subsubsection{Avaliações subjetivas}

Em todo o trecho analisado, além de quantificações objetivas dos defeitos, feitas com medidas de severidade e extensão, também foram feitas medidas subjetivas.

As avaliações subjetivas foram feitas por técnicos especializados, responsáveis pela manutenção da malha ferroviária em estudo e estão acostumados a identificar os diversos tipos de defeitos que podem ocorrer nas ferrovias e o grau de severidade que podem assumir. A experiência dos técnicos que fizeram os levantamentos varia de 4 a 8 anos de contato diário com a superestrutura da via férrea. Esses técnicos, ao identificarem os defeitos, deram pesos para cada defeito (coluna Conceito da Tabela 5.14), inicialmente como critério para identificar os locais que precisariam de manutenção com maior urgência, mas que nesta pesquisa foram tratados e usados para estimar a severidade que o defeito em dado elemento da superestrutura apresentava na data da avaliação. 
Semanalmente os técnicos percorrem todo o trecho estudado com o intuito de identificar visualmente os defeitos e propor intervenções de manutenção antes que uma situação crítica force o fechamento da via para reparos emergenciais. Esse trabalho é de praxe da concessionária nesses trechos da UP Norte e UP Centro e vêm trazendo bons resultados com relação ao índice de acidentes.

A calibração da avaliação subjetiva foi feita por meio de uma entrevista feita com cada avaliador para identificar a nota que cada um atribuía ao se deparar com determinado tipo de defeito com dado grau de severidade e, ainda, foram questionados acerca da condição geral do trecho analisado. Com isso foi possível elencar em determinado padrão as severidades em função da média das notas dadas pelos avaliadores.

\subsubsection{Densidade}

A análise da extensão de cada defeito foi feita proporcionalmente a um determinado comprimento de via ou elemento da superestrutura, desse modo pôde ser avaliada a quantidade de defeitos que ocorrem por unidade de comprimento ou de elemento.

À caracterização da quantidade de vezes que um tipo de defeito aparece em um trecho da via foi dado o nome de densidade. O comprimento analisado variou de acordo com o elemento estudado, por exemplo, para o lastro foi usado um comprimento de 50 metros, já os trilhos foram analisados por elemento ou trilhoequivalente de 12 metros. A densidade dos defeitos nos demais elementos da superestrutura da via foram calculados como exposto no item 3.2 do Capítulo 3.

\subsubsection{Curvas de ponderação}

As curvas de ponderação foram usadas primeiramente pelo USACERL para formular um índice de qualidade para pavimentos de aeroportos (SHAHIN, DARTER e KOHN, 
1976). Posteriormente esse conceito foi estendido para outros tipos de pavimentos, como os rodoviários (WANG e HAN, 2002).

Vários tipos diferentes de defeitos podem ocorrer em um determinado grupo de defeitos - como o de trilhos, juntas e acessórios - e cada um desses defeitos podem se apresentar em níveis de severidade distintos dentro do mesmo trecho. O conceito de curva de ponderação está em atribuir pesos para todas as relações defeitoseveridade-extensão por meio de notas dadas por um painel de avaliadores experientes, de tal forma que se possam traçar curvas de valores de ponderação em função da densidade de cada defeito e, assim, avaliar a qualidade da via não somente pela severidade do defeito, mas também por sua extensão.

As curvas de ponderação também devem levar em conta se um determinado defeito aparece mais de uma vez no mesmo trecho. Por isso, para cada defeito foram traçados grupos de curvas também em função do número de defeitos em um trecho.

As Tabelas 5.15 a 5.45 apresentam as notas dadas pelos especialistas para cada situação.

Tabela 5.15: Notas para lastro contaminado.

\begin{tabular}{c|c|c|c|c|c}
\hline $\begin{array}{c}\text { Densidade } \\
(\%)\end{array}$ & Avaliador 1 & Avaliador 2 & Avaliador 3 & Avaliador 4 & Avaliador 5 \\
\cline { 2 - 6 } & 100 & 100 & 100 & 100 & 100 \\
12 & 95 & 90 & 90 & 90 & 85 \\
18 & 85 & 80 & 75 & 80 & 80 \\
25 & 75 & 80 & 70 & 75 & 70 \\
\hline
\end{tabular}


Tabela 5.16: Notas para dormente mal conservado e severidade baixa.

\begin{tabular}{c|c|c|c|c|c}
\hline $\begin{array}{c}\text { Densidade } \\
(\%)\end{array}$ & \multicolumn{5}{|c}{ Nota } \\
\cline { 2 - 6 } & Avaliador 1 & Avaliador 2 & Avaliador 3 & Avaliador 4 & Avaliador 5 \\
\hline 0 & 100 & 100 & 100 & 100 & 100 \\
1 & 100 & 100 & 95 & 100 & 95 \\
5 & 90 & 95 & 90 & 90 & 90 \\
10 & 85 & 80 & 75 & 75 & 85 \\
\hline
\end{tabular}

Tabela 5.17: Notas para dormente mal conservado e severidade média.

\begin{tabular}{c|c|c|c|c|c}
\hline $\begin{array}{c}\text { Densidade } \\
(\%)\end{array}$ & \multicolumn{5}{|c}{ Nota } \\
\cline { 2 - 6 } & Avaliador 1 & Avaliador 2 & Avaliador 3 & Avaliador 4 & Avaliador 5 \\
\hline 0 & 100 & 100 & 100 & 100 & 100 \\
5 & 80 & 75 & 80 & 85 & 80 \\
10 & 70 & 65 & 70 & 75 & 65 \\
14 & 65 & 60 & 65 & 70 & 60 \\
\hline
\end{tabular}

Tabela 5.18: Notas para dormente mal conservado e severidade alta.

\begin{tabular}{c|c|c|c|c|c}
\hline $\begin{array}{c}\text { Densidade } \\
(\%)\end{array}$ & \multicolumn{5}{|c}{ Nota } \\
\cline { 2 - 6 } & Avaliador 1 & Avaliador 2 & Avaliador 3 & Avaliador 4 & Avaliador 5 \\
\hline 0 & 100 & 100 & 100 & 100 & 100 \\
2 & 90 & 95 & 90 & 90 & 90 \\
8 & 65 & 60 & 65 & 60 & 65 \\
21 & 50 & 45 & 45 & 40 & 50 \\
\hline
\end{tabular}


Tabela 5.19: Notas para dormente mal conservado e severidade muito alta.

\begin{tabular}{c|c|c|c|c|c}
\hline $\begin{array}{c}\text { Densidade } \\
(\%)\end{array}$ & Avaliador 1 & Avaliador 2 & Avaliador 3 & Avaliador 4 & Avaliador 5 \\
\cline { 2 - 6 } & 100 & 100 & 100 & 100 & 100 \\
1 & 90 & 90 & 90 & 90 & 90 \\
3 & 70 & 65 & 60 & 60 & 65 \\
9 & 40 & 45 & 45 & 40 & 40 \\
\hline
\end{tabular}

Tabela 5.20: Notas para dormente mal posicionado e severidade baixa.

\begin{tabular}{c|c|c|c|c|c}
\hline $\begin{array}{c}\text { Densidade } \\
(\%)\end{array}$ & Avaliador 1 & Avaliador 2 & Avaliador 3 & Avaliador 4 & Avaliador 5 \\
\cline { 2 - 6 } & 100 & 100 & 100 & 100 & 100 \\
10 & 80 & 85 & 80 & 85 & 75 \\
25 & 70 & 65 & 55 & 60 & 65 \\
37 & 60 & 55 & 40 & 50 & 55 \\
\hline
\end{tabular}

Tabela 5.21: Notas para dormente mal posicionado e severidade média.

\begin{tabular}{c|c|c|c|c|c}
\hline $\begin{array}{c}\text { Densidade } \\
(\%)\end{array}$ & \multicolumn{5}{|c}{ Nota } \\
\cline { 2 - 6 } & Avaliador 1 & Avaliador 2 & Avaliador 3 & Avaliador 4 & Avaliador 5 \\
\hline 0 & 100 & 100 & 100 & 100 & 100 \\
3 & 85 & 85 & 80 & 90 & 80 \\
19 & 40 & 45 & 45 & 40 & 50 \\
26 & 30 & 35 & 30 & 30 & 40 \\
\hline
\end{tabular}


Tabela 5.22: Notas para dormente mal posicionado e severidade alta.

\begin{tabular}{c|c|c|c|c|c}
\hline $\begin{array}{c}\text { Densidade } \\
(\%)\end{array}$ & \multicolumn{5}{|c}{ Nota } \\
\cline { 2 - 6 } & Avaliador 1 & Avaliador 2 & Avaliador 3 & Avaliador 4 & Avaliador 5 \\
\hline 0 & 100 & 100 & 100 & 100 & 100 \\
1 & 85 & 85 & 80 & 85 & 80 \\
4 & 50 & 45 & 50 & 40 & 50 \\
11 & 20 & 25 & 30 & 25 & 35 \\
\hline
\end{tabular}

Tabela 5.23: Notas para dormente faltando.

\begin{tabular}{c|c|c|c|c|c}
\hline $\begin{array}{c}\text { Densidade } \\
(\%)\end{array}$ & \multicolumn{5}{|c}{ Nota } \\
\cline { 2 - 6 } & Avaliador 1 & Avaliador 2 & Avaliador 3 & Avaliador 4 & Avaliador 5 \\
\hline 0 & 100 & 100 & 100 & 100 & 100 \\
1 & 100 & 95 & 100 & 100 & 95 \\
3 & 95 & 90 & 90 & 90 & 85 \\
6 & 80 & 75 & 75 & 80 & 75 \\
\hline
\end{tabular}

Tabela 5.24: Notas para trilhos com 1 tipo de defeito e severidade baixa.

\begin{tabular}{c|c|c|c|c|c}
\hline $\begin{array}{c}\text { Densidade } \\
(\%)\end{array}$ & \multicolumn{5}{|c}{ Nota } \\
\cline { 2 - 6 } & Avaliador 1 & Avaliador 2 & Avaliador 3 & Avaliador 4 & Avaliador 5 \\
\hline 0 & 100 & 100 & 100 & 100 & 100 \\
1 & 100 & 95 & 100 & 100 & 95 \\
10 & 95 & 85 & 90 & 90 & 85 \\
25 & 85 & 80 & 85 & 80 & 75 \\
\hline
\end{tabular}


Tabela 5.25: Notas para trilhos com 2 tipos de defeitos e severidade baixa.

\begin{tabular}{c|c|c|c|c|c}
\hline $\begin{array}{c}\text { Densidade } \\
(\%)\end{array}$ & Avaliador 1 & Avaliador 2 & Avaliador 3 & Avaliador 4 & Avaliador 5 \\
\cline { 2 - 6 } & 100 & 100 & 100 & 100 & 100 \\
5 & 95 & 85 & 90 & 95 & 90 \\
10 & 85 & 80 & 80 & 85 & 85 \\
15 & 80 & 75 & 75 & 80 & 80 \\
\hline
\end{tabular}

Tabela 5.26: Notas para trilhos com 3 tipos de defeitos e severidade baixa.

\begin{tabular}{c|c|c|c|c|c}
\hline $\begin{array}{c}\text { Densidade } \\
(\%)\end{array}$ & Avaliador 1 & Avaliador 2 & Avaliador 3 & Avaliador 4 & Avaliador 5 \\
\cline { 2 - 6 } & 100 & 100 & 100 & 100 & 100 \\
1 & 90 & 85 & 90 & 90 & 85 \\
5 & 80 & 80 & 85 & 85 & 75 \\
10 & 75 & 75 & 80 & 75 & 70 \\
\hline
\end{tabular}

Tabela 5.27: Notas para trilhos com 4 tipos de defeitos e severidade baixa.

\begin{tabular}{c|c|c|c|c|c}
\hline $\begin{array}{c}\text { Densidade } \\
(\%)\end{array}$ & \multicolumn{5}{|c}{ Nota } \\
\cline { 2 - 6 } & Avaliador 1 & Avaliador 2 & Avaliador 3 & Avaliador 4 & Avaliador 5 \\
\hline 0 & 100 & 100 & 100 & 100 & 100 \\
1 & 80 & 80 & 85 & 85 & 80 \\
5 & 70 & 65 & 75 & 80 & 70 \\
10 & 60 & 55 & 65 & 75 & 65 \\
\hline
\end{tabular}


Tabela 5.28: Notas para trilhos com 1 tipo de defeito e severidade média.

\begin{tabular}{c|c|c|c|c|c}
\hline $\begin{array}{c}\text { Densidade } \\
(\%)\end{array}$ & Avaliador 1 & Avaliador 2 & Avaliador 3 & Avaliador 4 & Avaliador 5 \\
\cline { 2 - 6 } & 100 & 100 & 100 & 100 & 100 \\
2 & 90 & 95 & 90 & 95 & 90 \\
12 & 80 & 80 & 80 & 75 & 80 \\
18 & 75 & 70 & 70 & 70 & 75 \\
\hline
\end{tabular}

Tabela 5.29: Notas para trilhos com 2 tipos de defeitos e severidade média.

\begin{tabular}{c|c|c|c|c|c}
\hline $\begin{array}{c}\text { Densidade } \\
(\%)\end{array}$ & \multicolumn{5}{|c}{ Nota } \\
\cline { 2 - 6 } & Avaliador 1 & Avaliador 2 & Avaliador 3 & Avaliador 4 & Avaliador 5 \\
\hline 0 & 100 & 100 & 100 & 100 & 100 \\
2 & 95 & 85 & 90 & 95 & 90 \\
6 & 85 & 80 & 80 & 85 & 85 \\
9 & 80 & 75 & 75 & 80 & 80 \\
\hline
\end{tabular}

Tabela 5.30: Notas para trilhos com 3 tipos de defeitos e severidade média.

\begin{tabular}{c|c|c|c|c|c}
\hline $\begin{array}{c}\text { Densidade } \\
(\%)\end{array}$ & \multicolumn{5}{|c}{ Nota } \\
\cline { 2 - 6 } & Avaliador 1 & Avaliador 2 & Avaliador 3 & Avaliador 4 & Avaliador 5 \\
\hline 0 & 100 & 100 & 100 & 100 & 100 \\
3 & 80 & 75 & 70 & 75 & 70 \\
10 & 60 & 65 & 65 & 65 & 60 \\
15 & 65 & 60 & 60 & 55 & 55 \\
\hline
\end{tabular}


Tabela 5.31: Notas para trilhos com 4 tipos de defeitos e severidade média.

\begin{tabular}{c|c|c|c|c|c}
\hline $\begin{array}{c}\text { Densidade } \\
(\%)\end{array}$ & \multicolumn{5}{|c}{ Nota } \\
\cline { 2 - 6 } & Avaliador 1 & Avaliador 2 & Avaliador 3 & Avaliador 4 & Avaliador 5 \\
\hline 0 & 100 & 100 & 100 & 100 & 100 \\
1 & 80 & 75 & 85 & 85 & 80 \\
4 & 70 & 60 & 75 & 75 & 70 \\
10 & 60 & 55 & 65 & 75 & 65 \\
\hline
\end{tabular}

Tabela 5.32: Notas para trilhos com 1 tipo de defeito e severidade alta.

\begin{tabular}{c|c|c|c|c|c}
\hline $\begin{array}{c}\text { Densidade } \\
(\%)\end{array}$ & \multicolumn{5}{|c}{ Nota } \\
\cline { 2 - 6 } & Avaliador 1 & Avaliador 2 & Avaliador 3 & Avaliador 4 & Avaliador 5 \\
\hline 0 & 100 & 100 & 100 & 100 & 100 \\
5 & 70 & 65 & 75 & 75 & 65 \\
10 & 45 & 55 & 45 & 50 & 45 \\
15 & 35 & 40 & 30 & 40 & 35 \\
\hline
\end{tabular}

Tabela 5.33: Notas para trilhos com 2 tipos de defeitos e severidade alta.

\begin{tabular}{c|c|c|c|c|c}
\hline $\begin{array}{c}\text { Densidade } \\
(\%)\end{array}$ & \multicolumn{5}{|c}{ Nota } \\
\cline { 2 - 6 } & Avaliador 1 & Avaliador 2 & Avaliador 3 & Avaliador 4 & Avaliador 5 \\
\hline 0 & 100 & 100 & 100 & 100 & 100 \\
5 & 65 & 60 & 70 & 65 & 60 \\
10 & 40 & 50 & 40 & 45 & 35 \\
15 & 35 & 35 & 30 & 35 & 25 \\
\hline
\end{tabular}


Tabela 5.34: Notas para trilhos com 3 tipos de defeitos e severidade alta.

\begin{tabular}{c|c|c|c|c|c}
\hline $\begin{array}{c}\text { Densidade } \\
(\%)\end{array}$ & Avaliador 1 & Avaliador 2 & Avaliador 3 & Avaliador 4 & Avaliador 5 \\
\cline { 2 - 6 } & 100 & 100 & 100 & 100 & 100 \\
5 & 55 & 55 & 60 & 50 & 50 \\
10 & 35 & 40 & 35 & 40 & 30 \\
15 & 30 & 30 & 25 & 30 & 20 \\
\hline
\end{tabular}

Tabela 5.35: Notas para trilhos com 4 tipos de defeitos e severidade alta.

\begin{tabular}{c|c|c|c|c|c}
\hline $\begin{array}{c}\text { Densidade } \\
(\%)\end{array}$ & Avaliador 1 & Avaliador 2 & Avaliador 3 & Avaliador 4 & Avaliador 5 \\
\cline { 2 - 6 } & 100 & 100 & 100 & 100 & 100 \\
5 & 50 & 45 & 50 & 45 & 40 \\
10 & 35 & 30 & 30 & 35 & 25 \\
15 & 30 & 25 & 25 & 20 & 20 \\
\hline
\end{tabular}

Tabela 5.36: Notas para ligação com 1 tipo de defeito e severidade baixa.

\begin{tabular}{c|c|c|c|c|c}
\hline $\begin{array}{c}\text { Densidade } \\
(\%)\end{array}$ & \multicolumn{5}{|c}{ Nota } \\
\cline { 2 - 6 } & Avaliador 1 & Avaliador 2 & Avaliador 3 & Avaliador 4 & Avaliador 5 \\
\hline 0 & 100 & 100 & 100 & 100 & 100 \\
13 & 95 & 90 & 90 & 95 & 90 \\
25 & 85 & 80 & 85 & 90 & 80 \\
38 & 75 & 70 & 75 & 80 & 75 \\
\hline
\end{tabular}


Tabela 5.37: Notas para ligação com 2 tipos de defeitos e severidade baixa.

\begin{tabular}{c|c|c|c|c|c}
\hline $\begin{array}{c}\text { Densidade } \\
(\%)\end{array}$ & \multicolumn{5}{|c}{ Nota } \\
\cline { 2 - 6 } & Avaliador 1 & Avaliador 2 & Avaliador 3 & Avaliador 4 & Avaliador 5 \\
\hline 0 & 100 & 100 & 100 & 100 & 100 \\
10 & 85 & 80 & 90 & 80 & 85 \\
20 & 75 & 70 & 80 & 70 & 70 \\
40 & 65 & 60 & 70 & 65 & 60 \\
\hline
\end{tabular}

Tabela 5.38: Notas para ligação com 3 tipos de defeitos e severidade baixa.

\begin{tabular}{c|c|c|c|c|c}
\hline $\begin{array}{c}\text { Densidade } \\
(\%)\end{array}$ & \multicolumn{5}{|c}{ Nota } \\
\cline { 2 - 6 } & Avaliador 1 & Avaliador 2 & Avaliador 3 & Avaliador 4 & Avaliador 5 \\
\hline 0 & 100 & 100 & 100 & 100 & 100 \\
10 & 80 & 75 & 85 & 75 & 80 \\
20 & 70 & 60 & 70 & 60 & 65 \\
40 & 60 & 50 & 60 & 45 & 50 \\
\hline
\end{tabular}

Tabela 5.39: Notas para ligação com 1 tipo de defeito e severidade baixa.

\begin{tabular}{c|c|c|c|c|c}
\hline $\begin{array}{c}\text { Densidade } \\
(\%)\end{array}$ & \multicolumn{5}{|c}{ Nota } \\
\cline { 2 - 6 } & Avaliador 1 & Avaliador 2 & Avaliador 3 & Avaliador 4 & Avaliador 5 \\
\hline 0 & 100 & 100 & 100 & 100 & 100 \\
13 & 75 & 70 & 70 & 75 & 70 \\
25 & 65 & 60 & 55 & 60 & 60 \\
38 & 55 & 50 & 45 & 50 & 45 \\
\hline
\end{tabular}


Tabela 5.40: Notas para ligação com 2 tipos de defeitos e severidade baixa.

\begin{tabular}{c|c|c|c|c|c}
\hline $\begin{array}{c}\text { Densidade } \\
(\%)\end{array}$ & Avaliador 1 & Avaliador 2 & Avaliador 3 & Avaliador 4 & Avaliador 5 \\
\cline { 2 - 6 } & 100 & 100 & 100 & 100 & 100 \\
10 & 70 & 75 & 65 & 70 & 65 \\
20 & 60 & 65 & 50 & 55 & 45 \\
40 & 50 & 55 & 35 & 40 & 35 \\
\hline
\end{tabular}

Tabela 5.41: Notas para ligação com 3 tipos de defeitos e severidade baixa.

\begin{tabular}{c|c|c|c|c|c}
\hline $\begin{array}{c}\text { Densidade } \\
(\%)\end{array}$ & Avaliador 1 & Avaliador 2 & Avaliador 3 & Avaliador 4 & Avaliador 5 \\
\cline { 2 - 6 } & 100 & 100 & 100 & 100 & 100 \\
10 & 70 & 70 & 65 & 65 & 60 \\
20 & 50 & 55 & 45 & 45 & 40 \\
40 & 45 & 45 & 30 & 35 & 30 \\
\hline
\end{tabular}

Tabela 5.42: Notas para ligação com 1 tipos de defeitos e severidade alta.

\begin{tabular}{c|c|c|c|c|c}
\hline $\begin{array}{c}\text { Densidade } \\
(\%)\end{array}$ & \multicolumn{5}{|c}{ Nota } \\
\cline { 2 - 6 } & Avaliador 1 & Avaliador 2 & Avaliador 3 & Avaliador 4 & Avaliador 5 \\
\hline 0 & 100 & 100 & 100 & 100 & 100 \\
13 & 50 & 45 & 60 & 50 & 55 \\
25 & 40 & 35 & 45 & 35 & 40 \\
38 & 30 & 20 & 35 & 25 & 30 \\
\hline
\end{tabular}


Tabela 5.43: Notas para ligação com 1 tipos de defeito e severidade muito alta.

\begin{tabular}{c|c|c|c|c|c}
\hline $\begin{array}{c}\text { Densidade } \\
(\%)\end{array}$ & \multicolumn{5}{|c}{ Nota } \\
\cline { 2 - 6 } & Avaliador 1 & Avaliador 2 & Avaliador 3 & Avaliador 4 & Avaliador 5 \\
\hline 0 & 100 & 100 & 100 & 100 & 100 \\
13 & 40 & 35 & 45 & 40 & 35 \\
25 & 30 & 25 & 25 & 25 & 20 \\
38 & 25 & 15 & 20 & 20 & 15 \\
\hline
\end{tabular}

Tabela 5.44: Notas para fixação com 1 tipos de defeito e severidade alta.

\begin{tabular}{c|c|c|c|c|c}
\hline $\begin{array}{c}\text { Densidade } \\
(\%)\end{array}$ & Avaliador 1 & Avaliador 2 & Avaliador 3 & Avaliador 4 & Avaliador 5 \\
\cline { 2 - 6 } & 100 & 100 & 100 & 100 & 100 \\
10 & 80 & 90 & 80 & 75 & 80 \\
20 & 55 & 70 & 60 & 65 & 65 \\
30 & 35 & 45 & 40 & 40 & 45 \\
\hline
\end{tabular}

Tabela 5.45: Notas para fixação com 2 tipos de defeito e severidade alta.

\begin{tabular}{c|c|c|c|c|c}
\hline $\begin{array}{c}\text { Densidade } \\
(\%)\end{array}$ & Avaliador 1 & Avaliador 2 & Avaliador 3 & Avaliador 4 & Avaliador 5 \\
\cline { 2 - 6 } & 100 & 100 & 100 & 100 & 100 \\
10 & 60 & 70 & 65 & 60 & 70 \\
20 & 45 & 55 & 40 & 40 & 45 \\
30 & 25 & 35 & 30 & 25 & 20 \\
\hline
\end{tabular}

As curvas traçadas representam a linha de tendência formada pelas médias aritméticas das notas dos avaliadores para cada situação. A escala das notas dadas variou de 0 a 100 e os valores de ponderação foram determinados subtraindo a nota 
dada de 100, com o intuito de que a maior nota, ou seja, a melhor situação tivesse impacto menor na determinação da deterioração da via. Como não havia defeitos suficientes que abrangessem toda a extensão de cada trecho avaliado, as curvas de ponderação foram extrapoladas até a densidade de 100\%, com mais um ponto intermediário em 50\%, com notas atribuídas junto aos avaliadores ao se considerar tal hipótese. Considerou-se, ainda, continuidade de comportamento das curvas na região extrapolada com relação à região efetivamente avaliada.

As Figuras 5.9 a 5.25 apresentam as curvas de ponderação para cada relação defeito-severidade-extensão considerada na pesquisa. As linhas cheias representam os valores calibrados junto aos avaliadores e as linhas tracejadas os valores extrapolados.

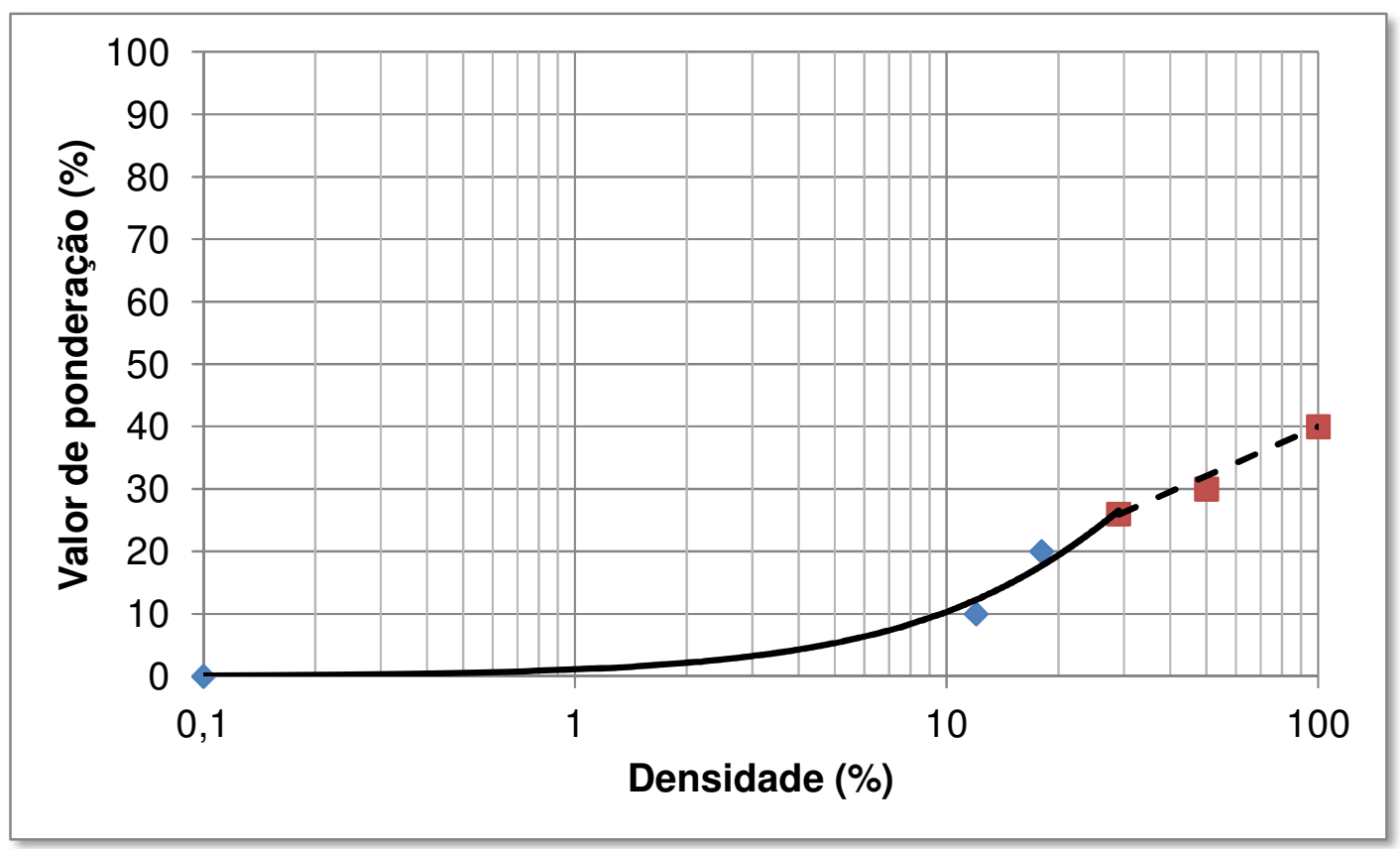

Figura 5.9: Curva de ponderação para lastro contaminado. 


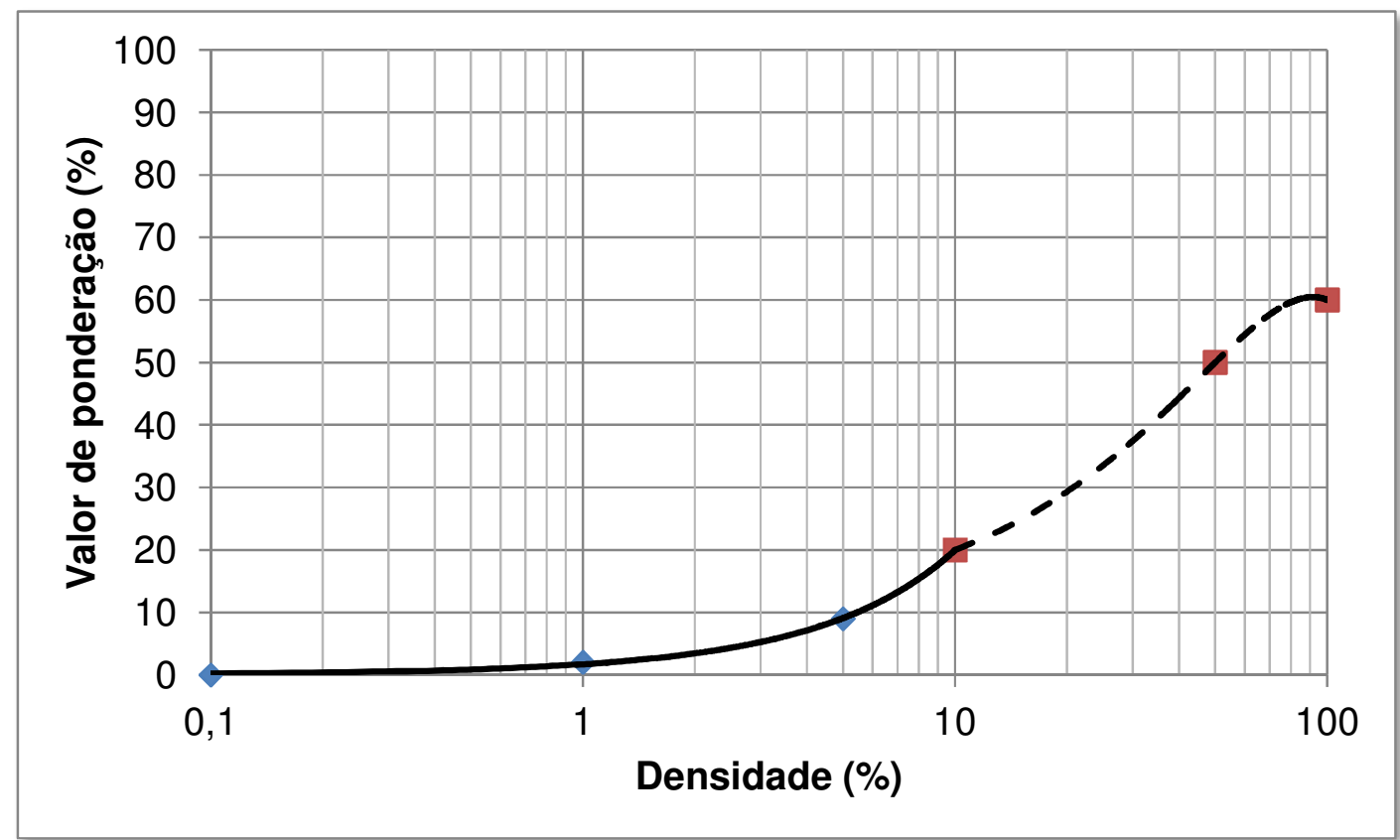

Figura 5.10: Curva de ponderação para dormente em mau estado e severidade baixa.

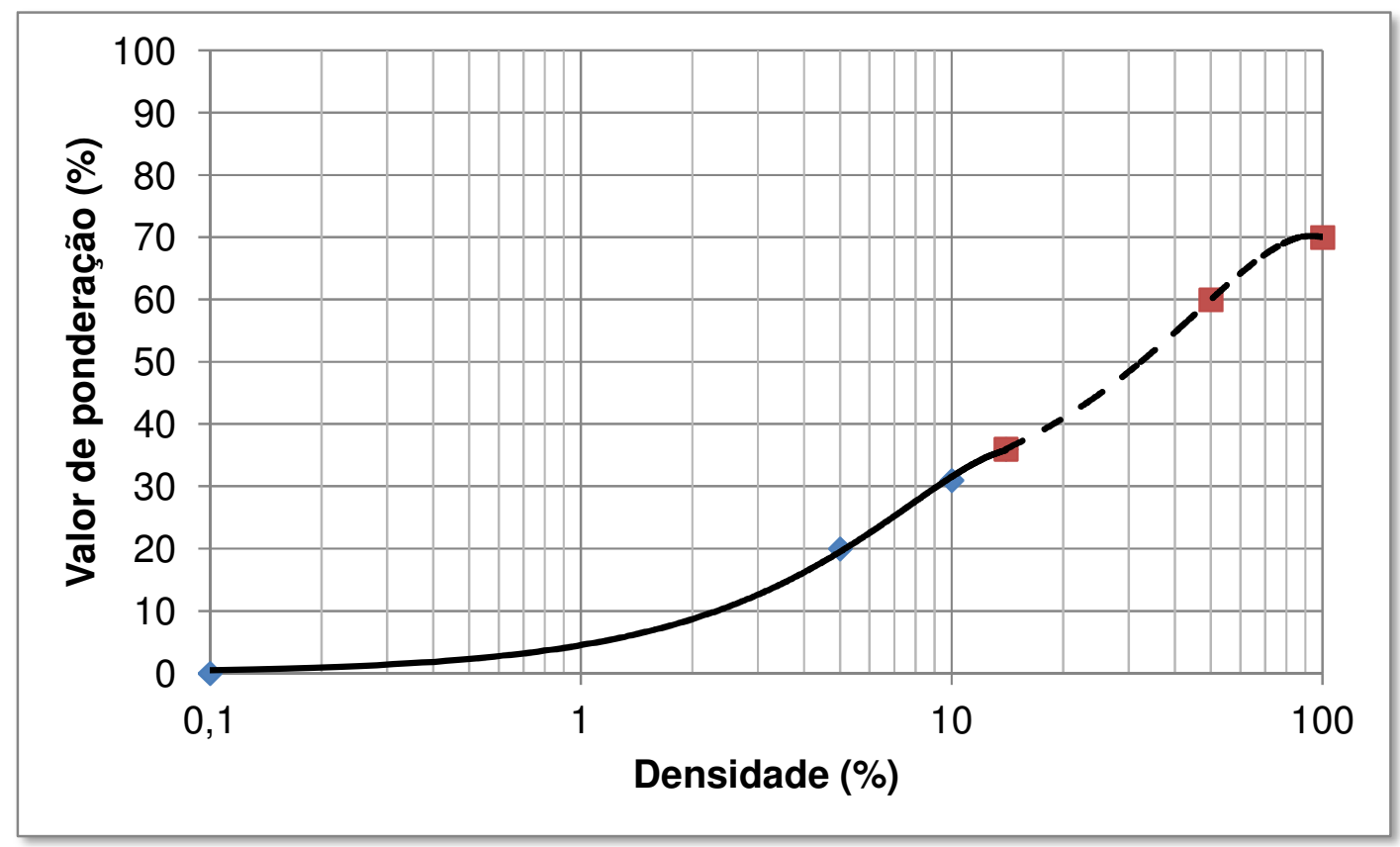

Figura 5.11: Curva de ponderação para dormente em mau estado e severidade média. 


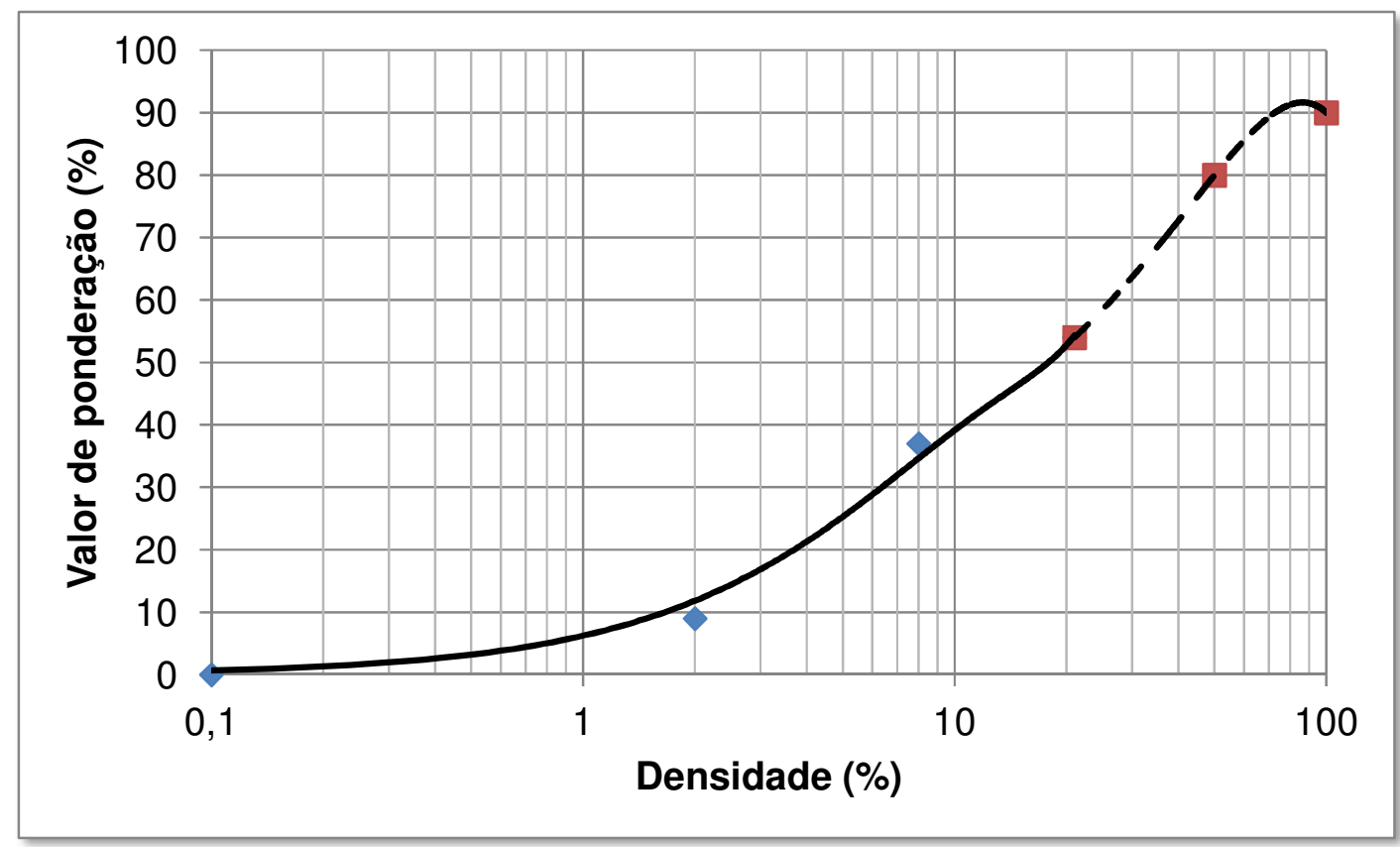

Figura 5.12: Curva de ponderação para dormente em mau estado e severidade alta

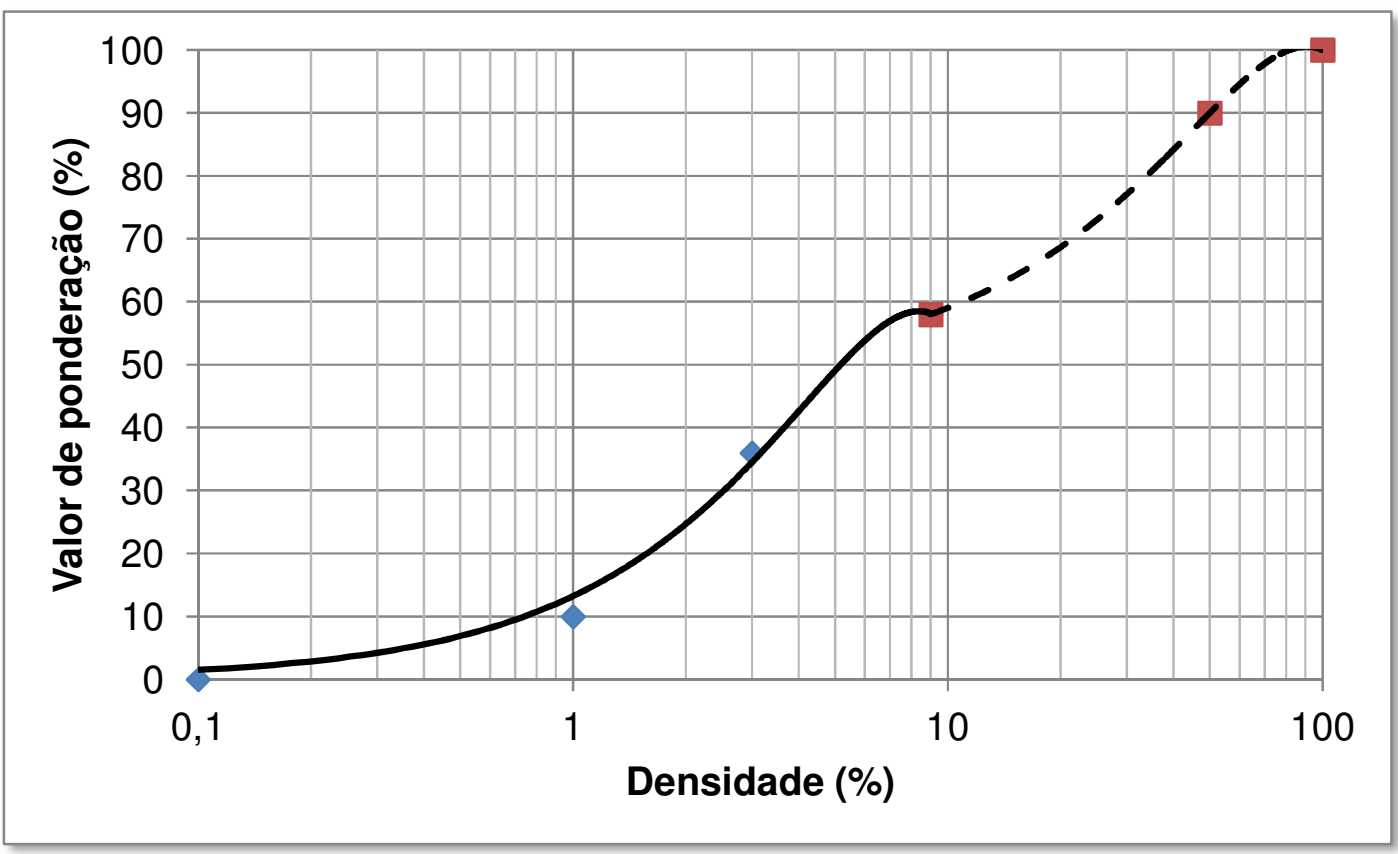

Figura 5.13: Curva de ponderação para dormente em mau estado e severidade muito alta. 


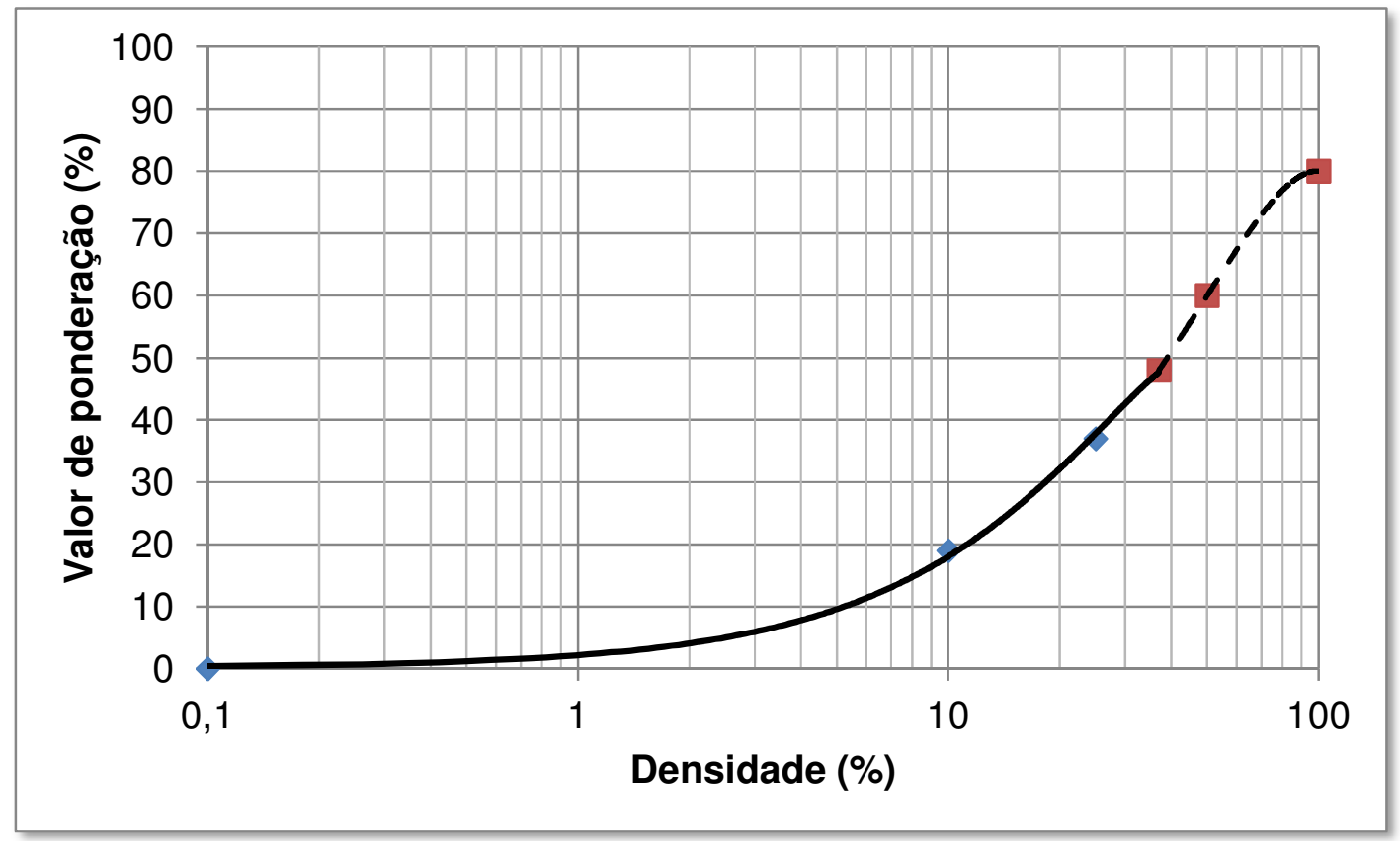

Figura 5.14: Curva de ponderação para dormente mal posicionado e severidade baixa.

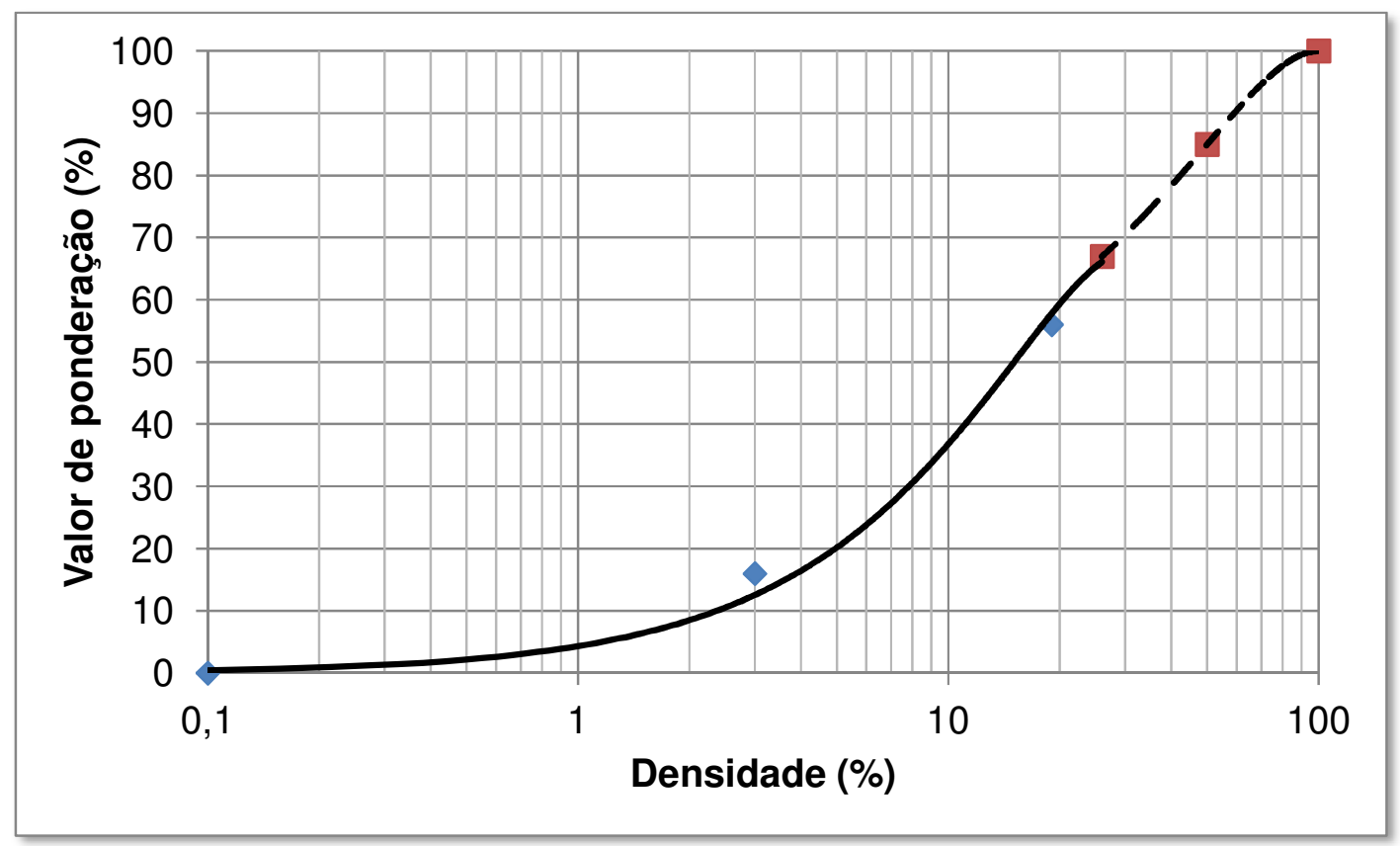

Figura 5.15: Curva de ponderação para dormente mal posicionado e severidade média. 


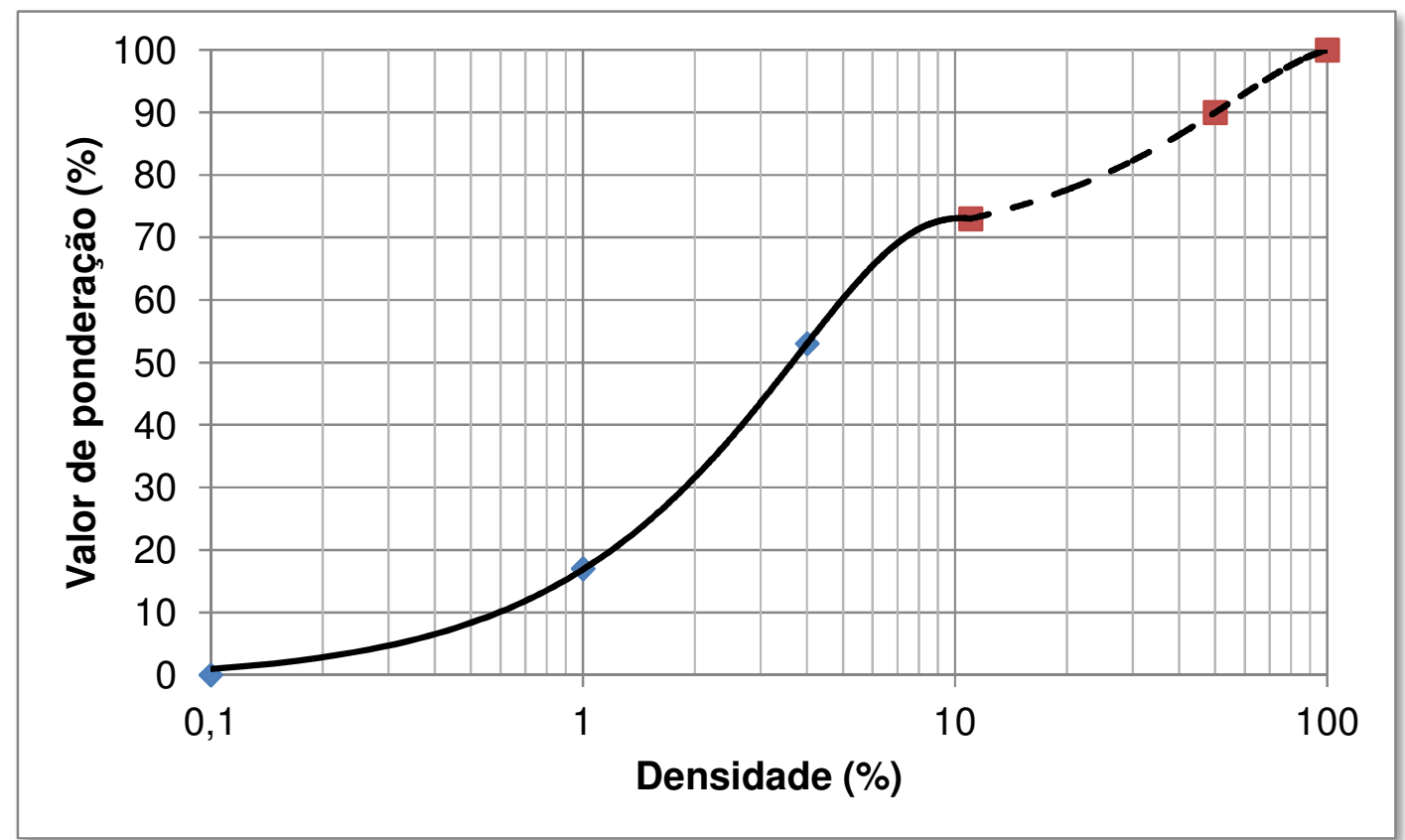

Figura 5.16: Curva de ponderação para dormente mal posicionado e severidade alta.

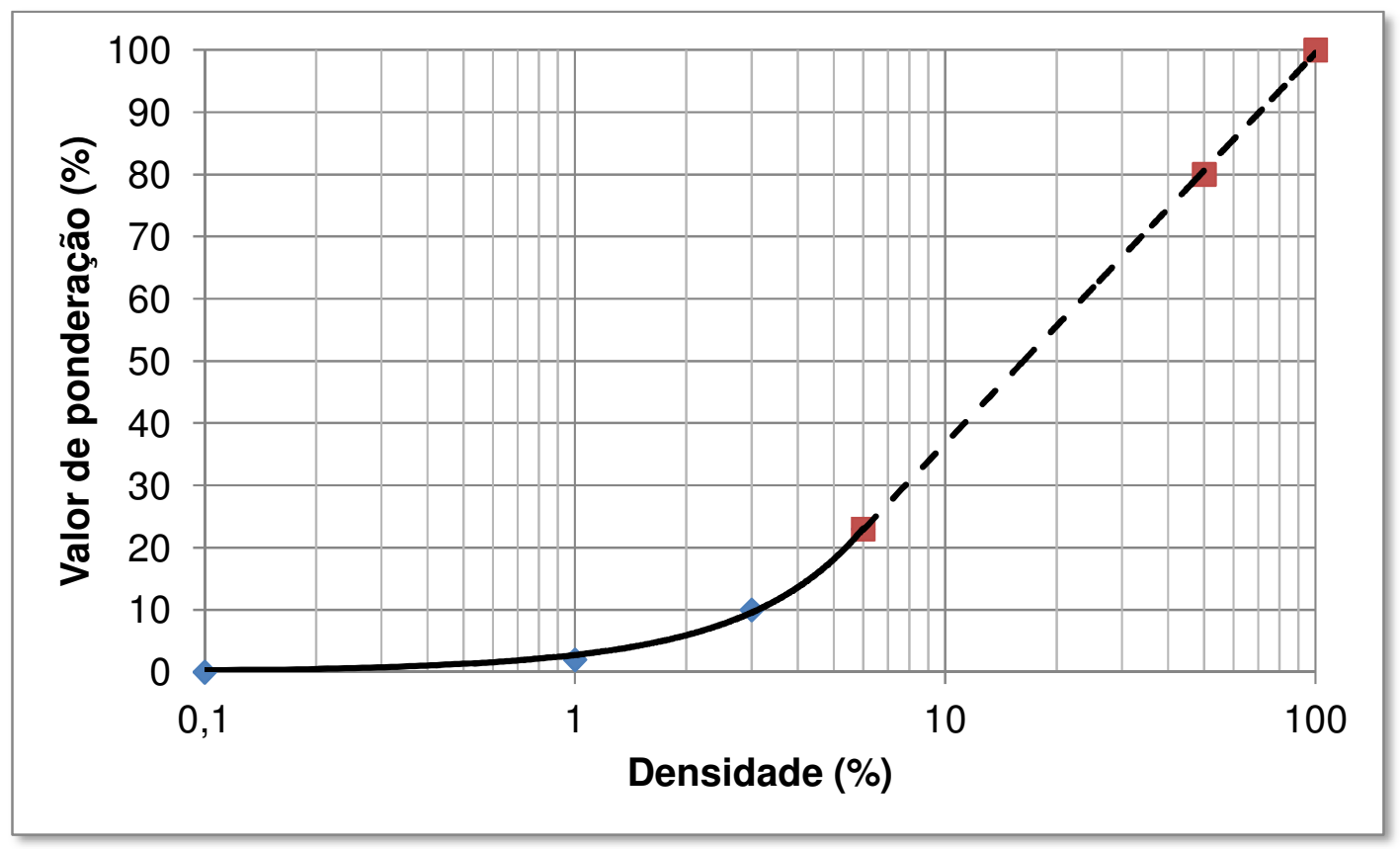

Figura 5.17: Curva de ponderação para dormente faltando. 


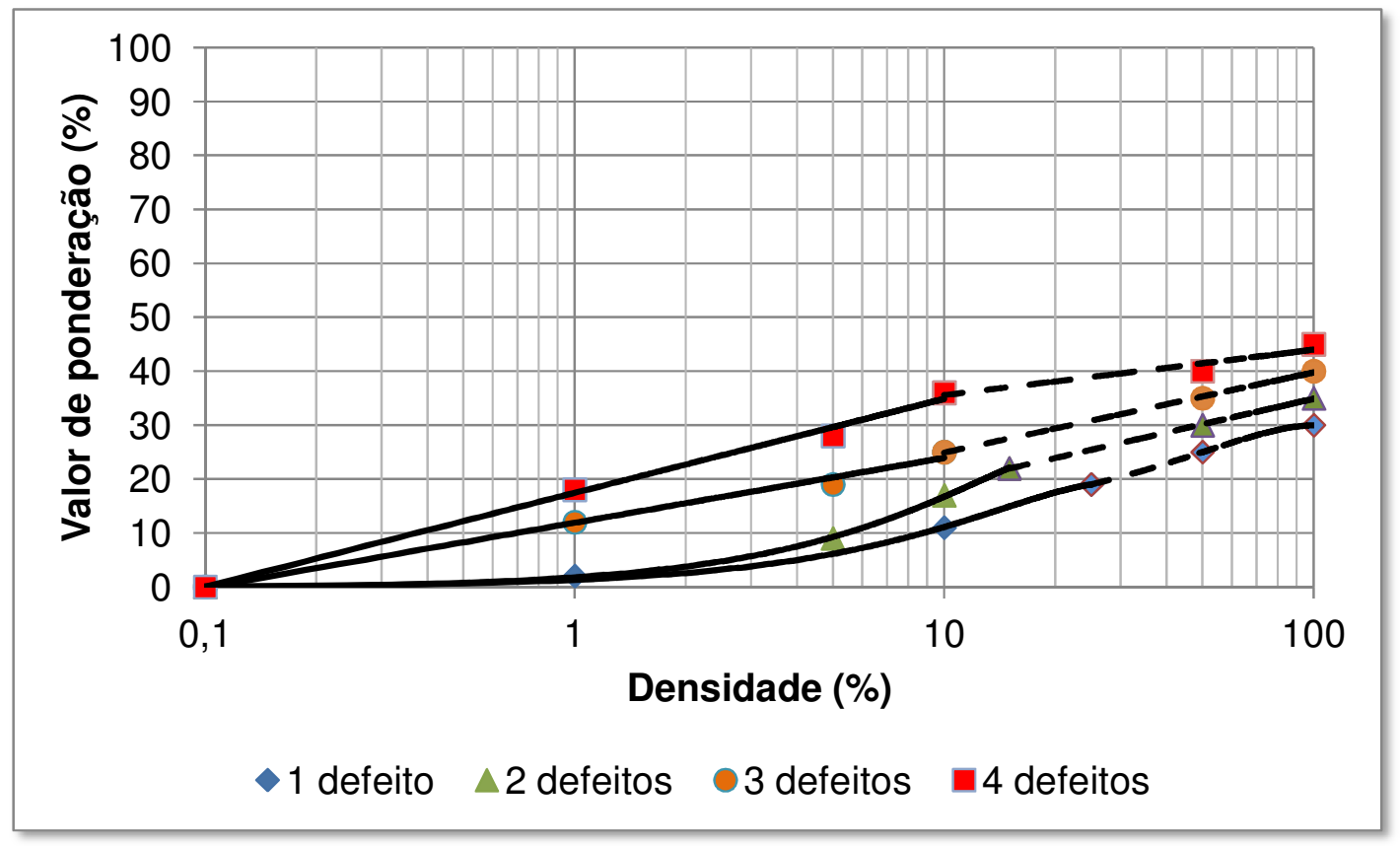

Figura 5.18: Curvas de ponderação para trilhos com 1, 2, 3 ou 4 tipos de defeitos e severidade baixa.

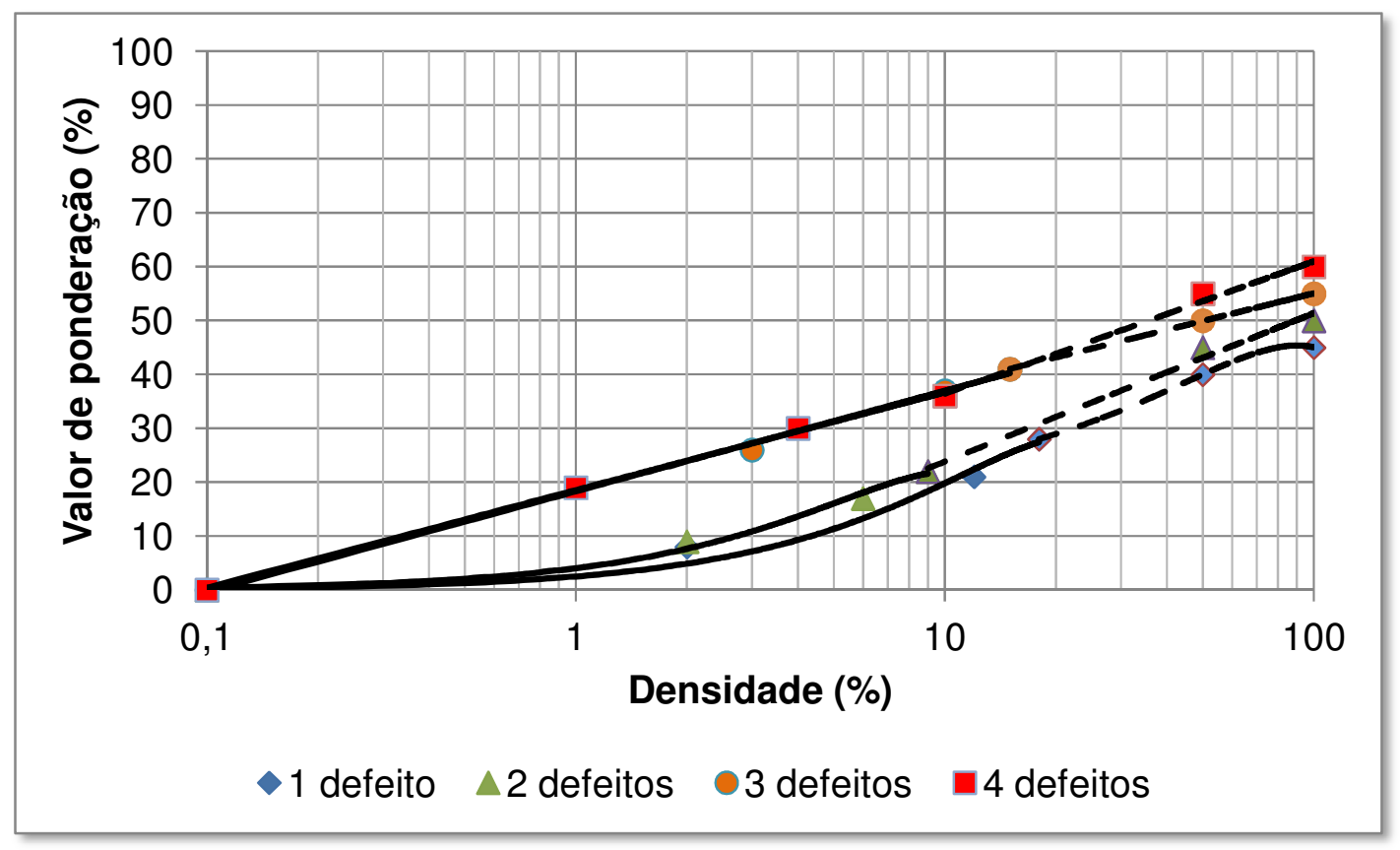

Figura 5.19: Curvas de ponderação para trilhos com 1, 2, 3 ou 4 tipos de defeitos e severidade média. 


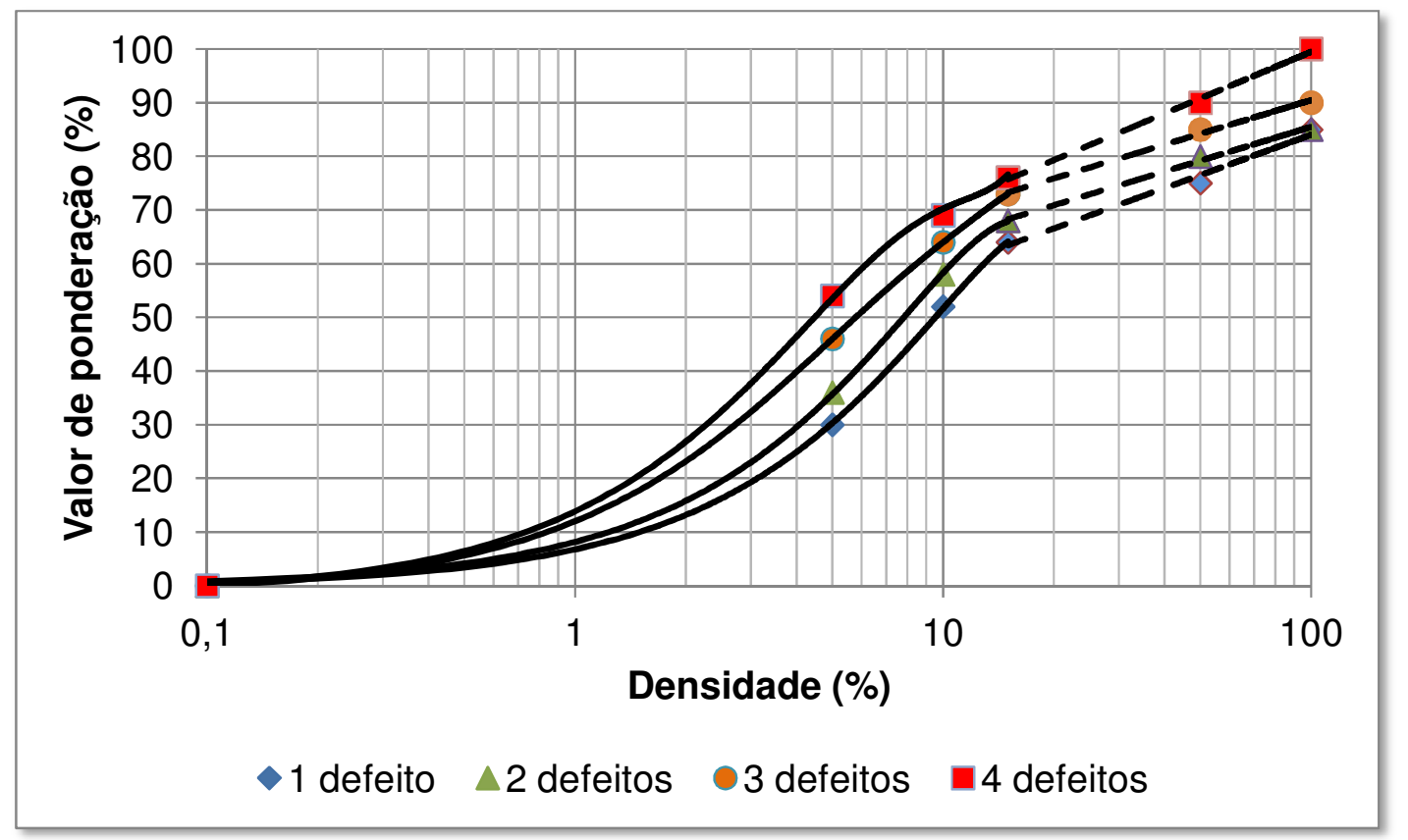

Figura 5.20: Curvas de ponderação para trilhos com 1, 2, 3 ou 4 tipos de defeitos e severidade alta.

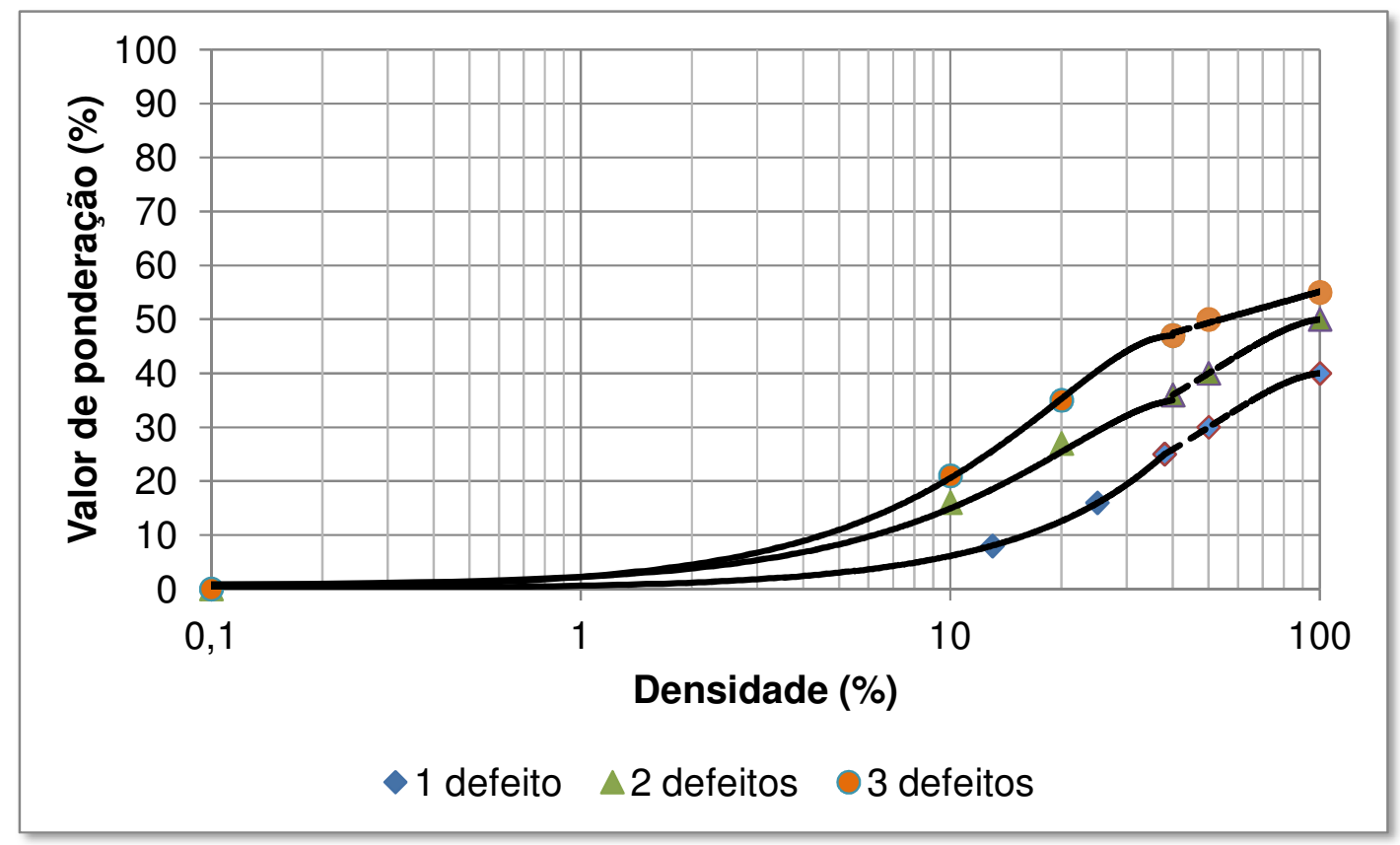

Figura 5.21: Curvas de ponderação para juntas com 1, 2 ou 3 tipos de defeitos e severidade baixa. 


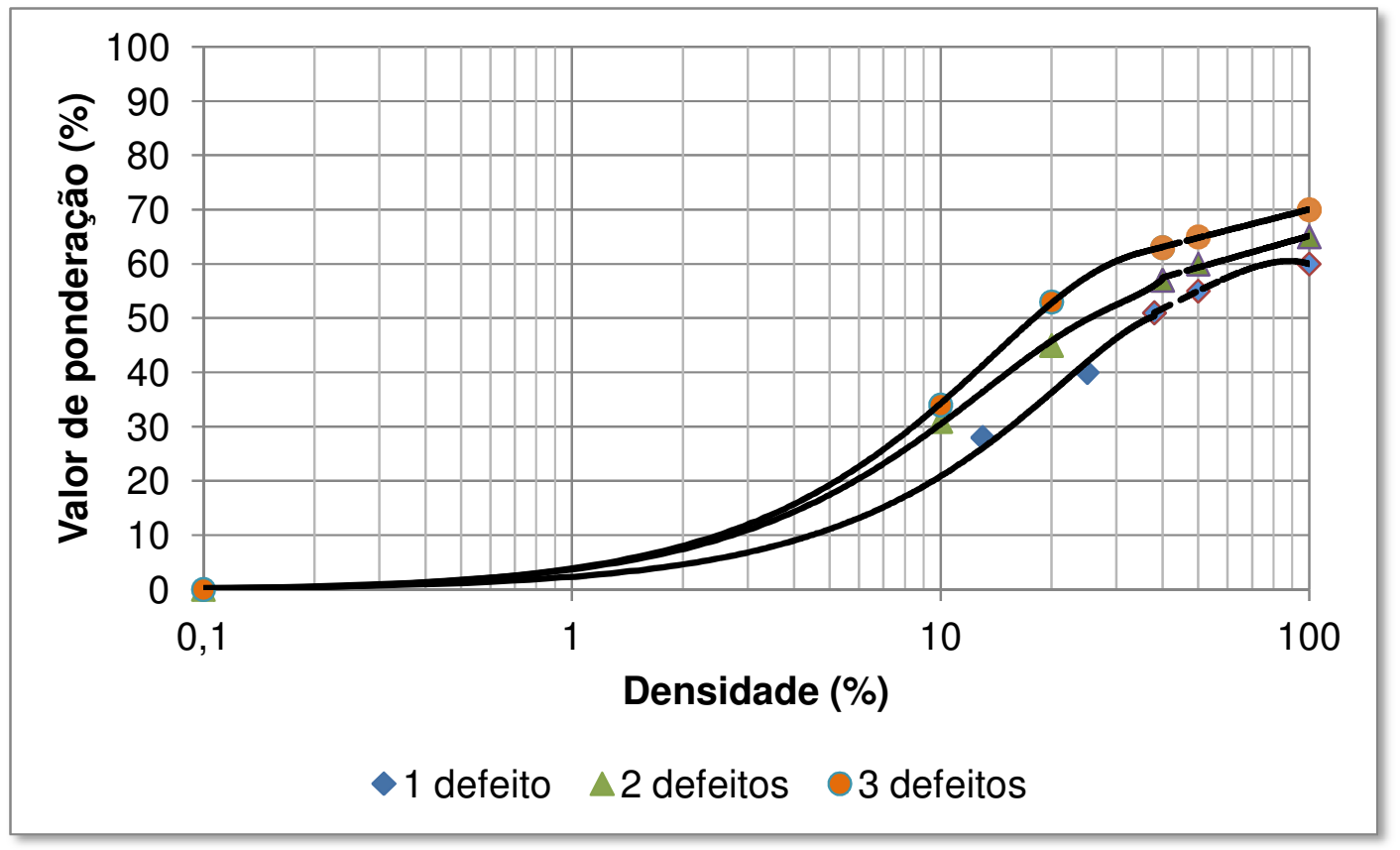

Figura 5.22: Curvas de ponderação para juntas com 1, 2 ou 3 tipos de defeitos e severidade média.

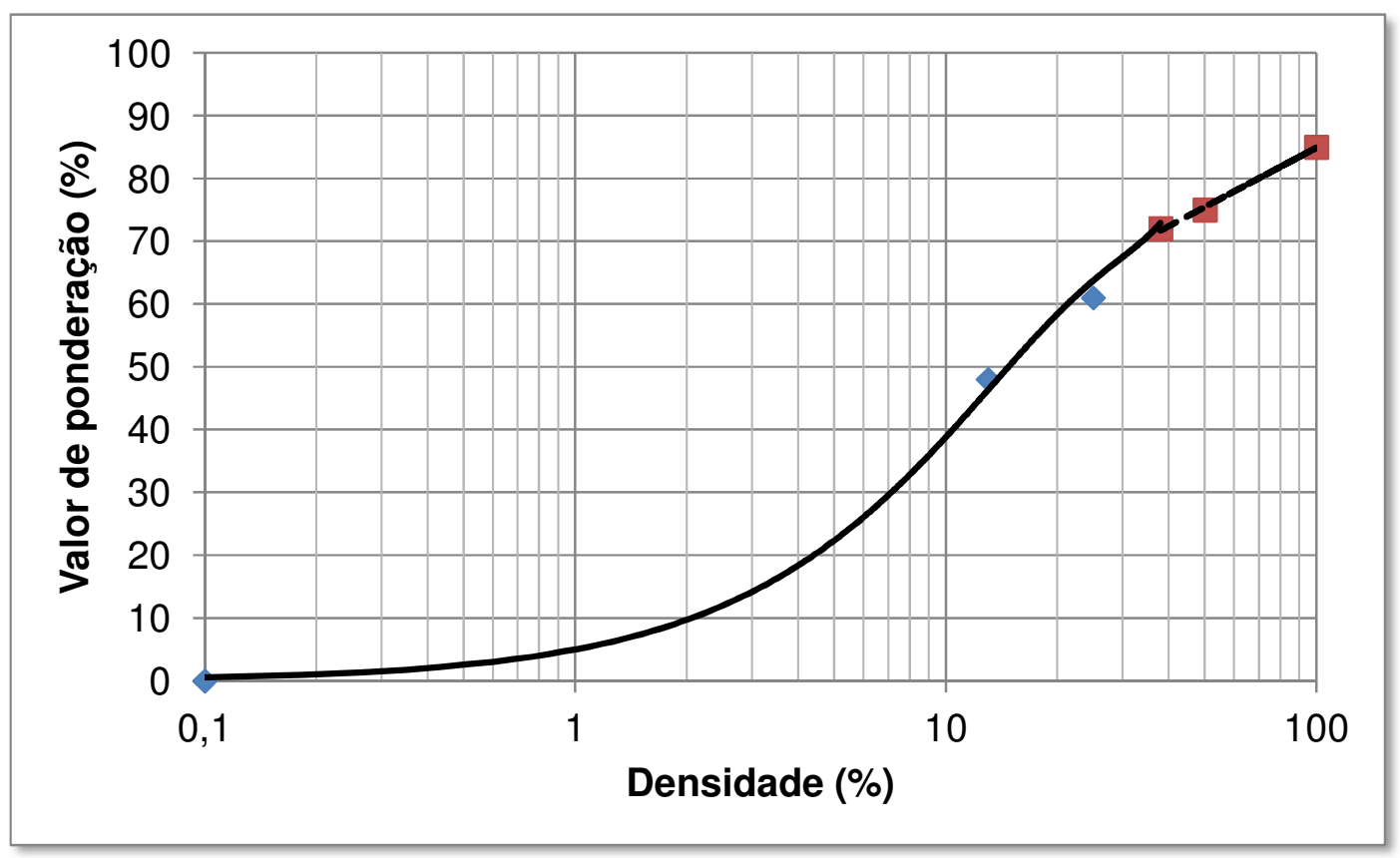

Figura 5.23: Curva de ponderação para juntas com 1 tipos de defeitos e severidade alta. 


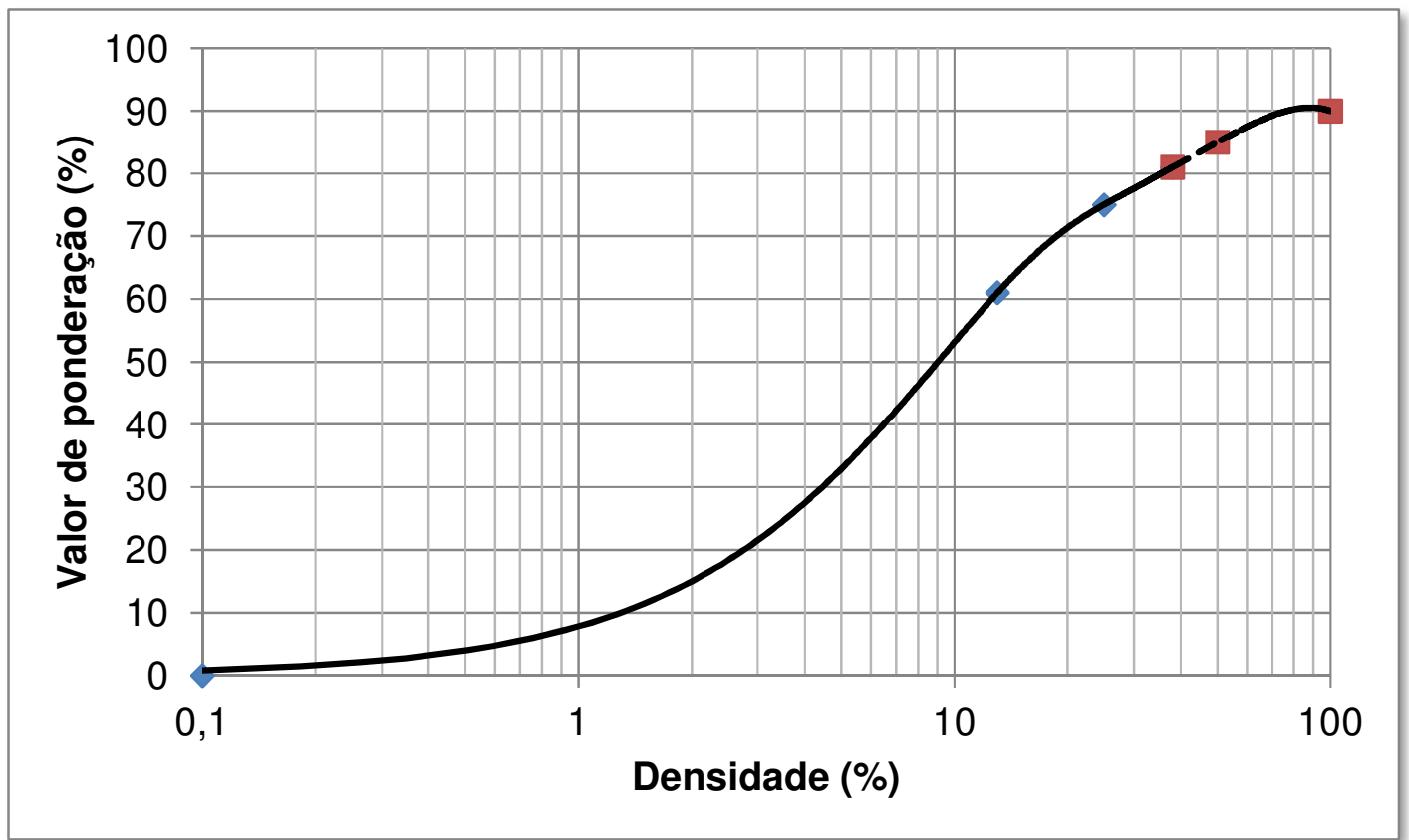

Figura 5.24: Curva de ponderação para juntas com 1 tipos de defeitos e severidade muito alta.

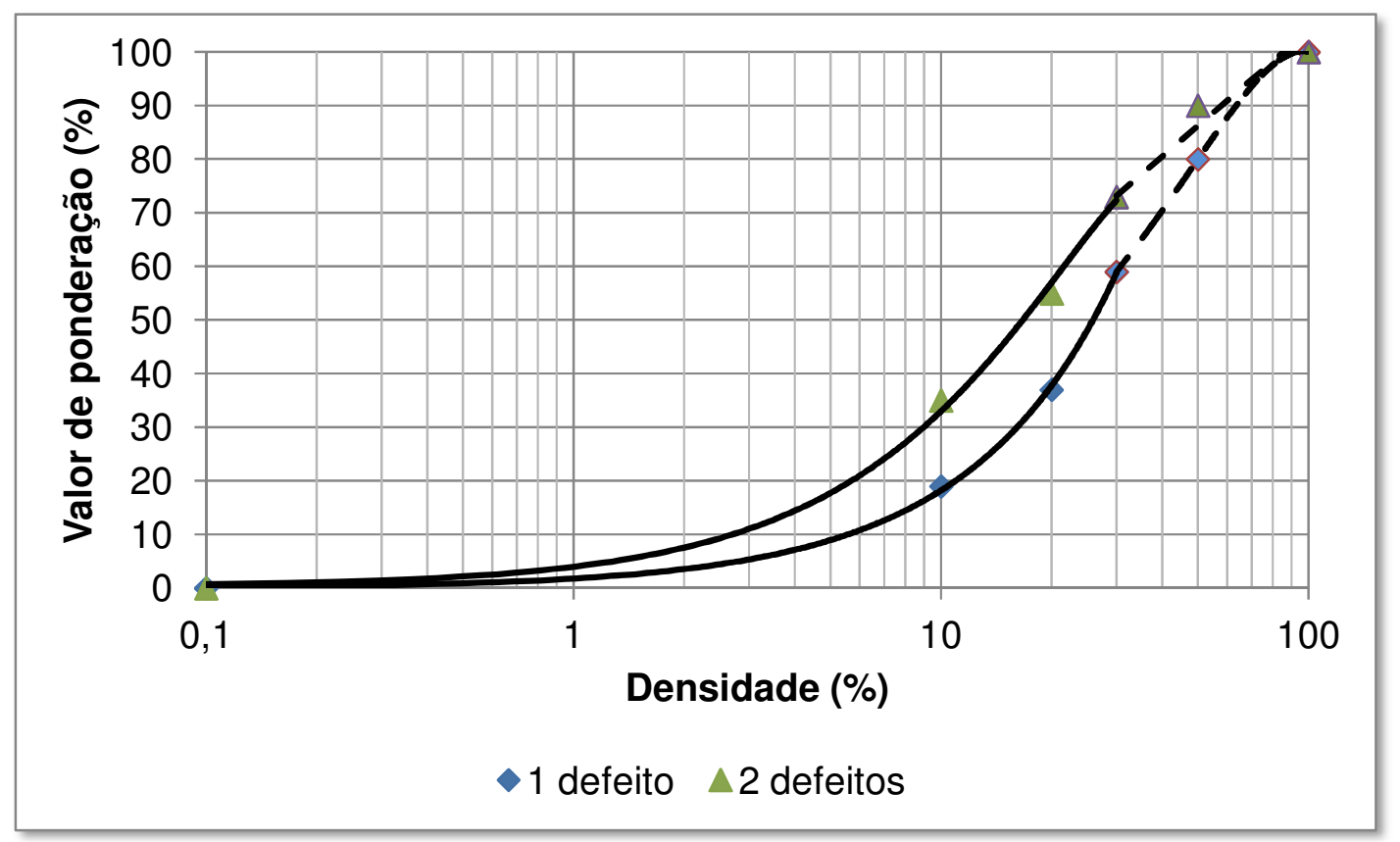

Figura 5.25: Curva de ponderação para fixação com 1 ou 2 tipos de defeitos e severidade alta. 


\subsubsection{Curvas de correção}

Os modelos representados pelos índices de condição devem levar em conta que mais de um tipo de defeito ou diversos níveis de severidade de um mesmo defeito podem ocorrer em um mesmo elemento ou trecho da ferrovia. Em face disso, um dado defeito acaba tendo um impacto menor na condição da via quando ocorre junto com outros tipos de defeitos ou níveis de severidade.

Com o intuito de ponderar a condição da via quando esta se encontra com diversos tipos de defeitos e níveis de severidade, foram criadas as curvas de correção, que são definidas em função de um determinado grupo de defeitos, da soma total de valores individuais ponderados, de um valor ponderado mínimo individual, do número de diferentes tipos de defeito e das severidades. De forma simplificada, as curvas de correção são determinadas pela relação dos valores individuais ponderados pela somatória de valores ponderados e cada defeito avaliado gera uma curva de correção.

As curvas de correção usadas nesta pesquisa são baseadas nas curvas propostas por Uzarski (1991). A Figura 5.26 apresenta as curvas de correção para o grupo "Trilhos, Juntas e Acessório" e a Figura 5.27 para o grupo "Dormentes". Para o grupo "Lastro" não houve necessidade de se criarem curvas de correção, uma vez que o único defeito analisado foi se o lastro estava contaminado, sem níveis de severidade. A variável "q" indica o número de defeitos e/ou severidades encontrados em cada análise. 


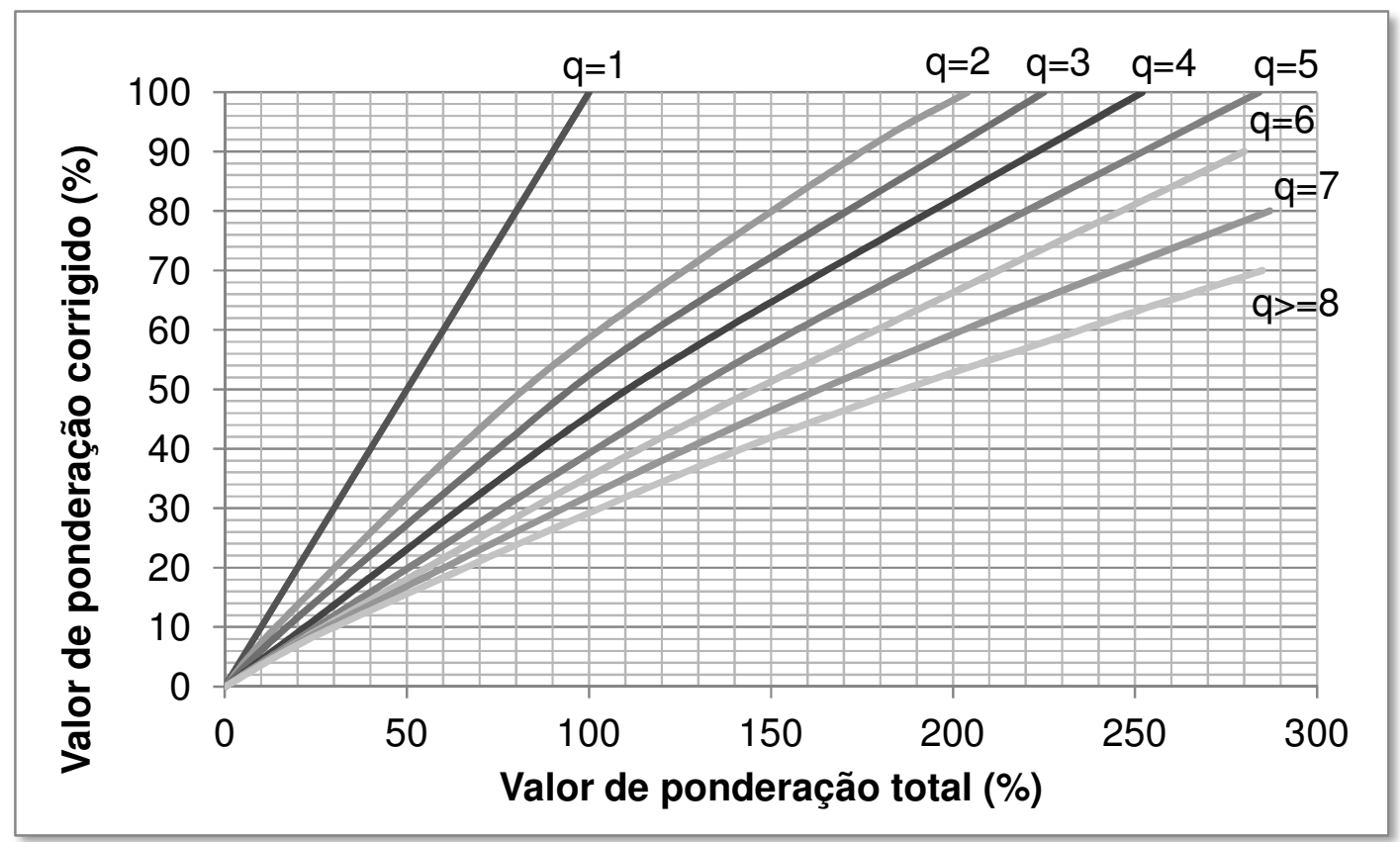

Figura 5.26: Curvas de correção para o grupo "Trilhos, Juntas e Acessórios".

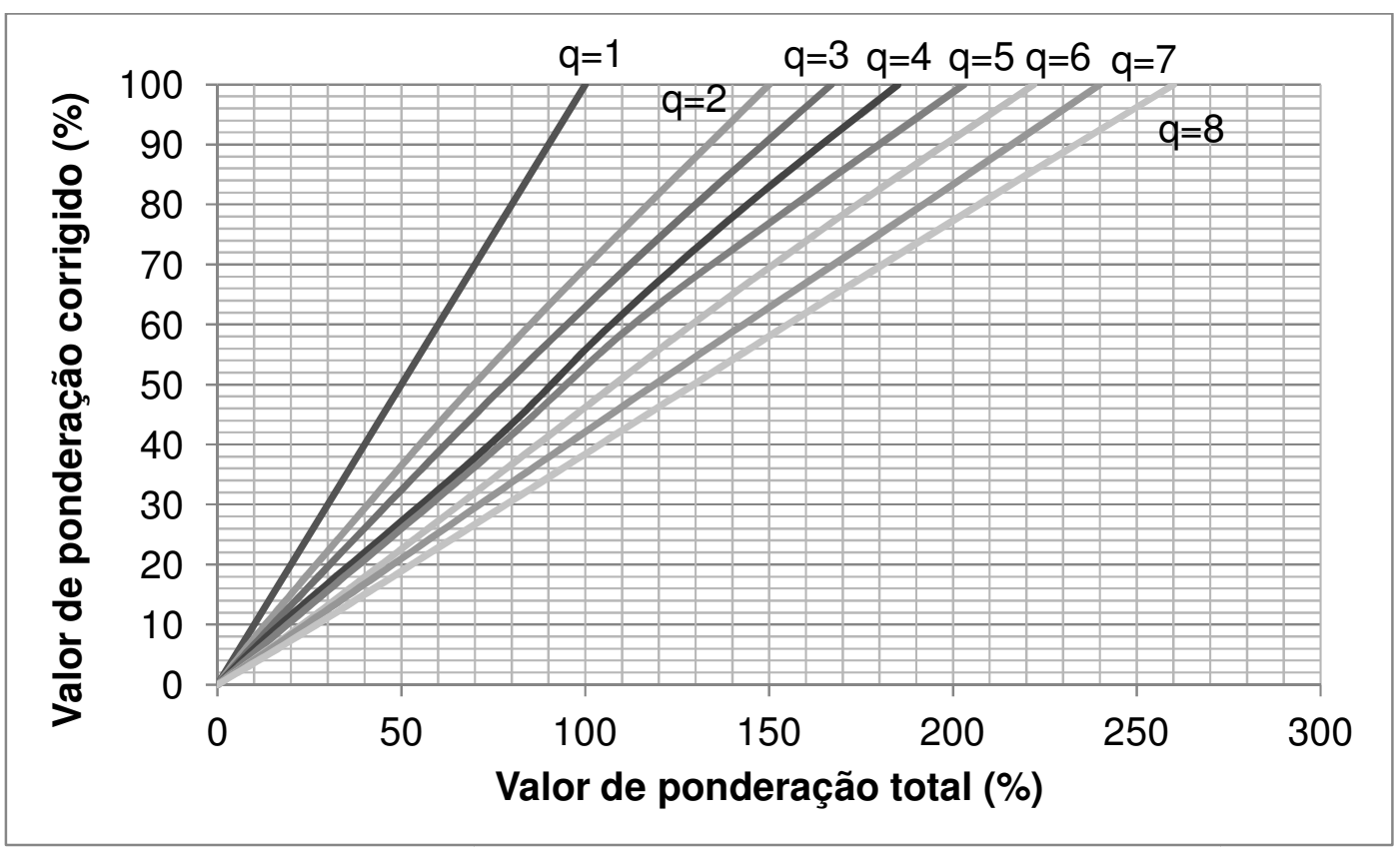

Figura 5.27: Curvas de correção para o grupo "Dormentes". 


\subsubsection{Proposição de índices estruturais individuais e global}

Os índices estruturais propostos nesse item foram divididos para representar cada grupo de defeitos e também para representar a condição global da via.

Os modelos que representam cada grupo podem ser expressos genericamente pela Equação 5.9.

$$
\mathrm{IC}=100-\sum_{i=0}^{d} \sum_{j=0}^{s} P\left(d_{i} ; s_{j} ; D_{i j}\right) \cdot C(d ; s)
$$

Em que:

IC = índice de condição para cada grupo;

$\mathrm{P}=$ valor de ponderação;

$\mathrm{d}=$ tipo de defeito;

$\mathrm{s}=$ nível de severidade;

$\mathrm{D}=$ densidade;

$\mathrm{C}=$ fator de correção.

O valor de "P" é determinado por meio das curvas de ponderação propostas anteriormente e o valor de "C" por meio das curvas de correção.

Para validar os modelos feitos para cada grupo, confrontaram-se as médias dos índices de condição calculados para trechos aleatórios da malha ferroviária estudada, com a média das avaliações feitas pelos avaliadores. As Figuras 5.28, 5.29 e 5.30 mostram as relações entre esses parâmetros para cada grupo de defeitos, bem como coeficiente de determinação de cada relação.

Os índices ficaram assim definidos:

- ICET: Índice de condição estrutural do grupo Trilhos, Juntas e Acessórios;

- ICED: Índice de condição estrutural do grupo Dormentes;

- ICEL: Índice de condição estrutural do grupo Lastro. 
Denominaram-se as avaliações nos trechos como:

- ACET: Média das avaliações da condição estrutural do grupo Trilhos, Juntas e Acessórios para cada trecho;

- ACED: Média das avaliações da condição estrutural do grupo Dormentes para cada trecho;

- ACEL: Média das avaliações da condição estrutural do grupo Lastro para cada trecho;

As linhas cheias representam as curvas de tendência dos parâmetros avaliados e as linhas tracejadas, a extrapolação para esses mesmos parâmetros.

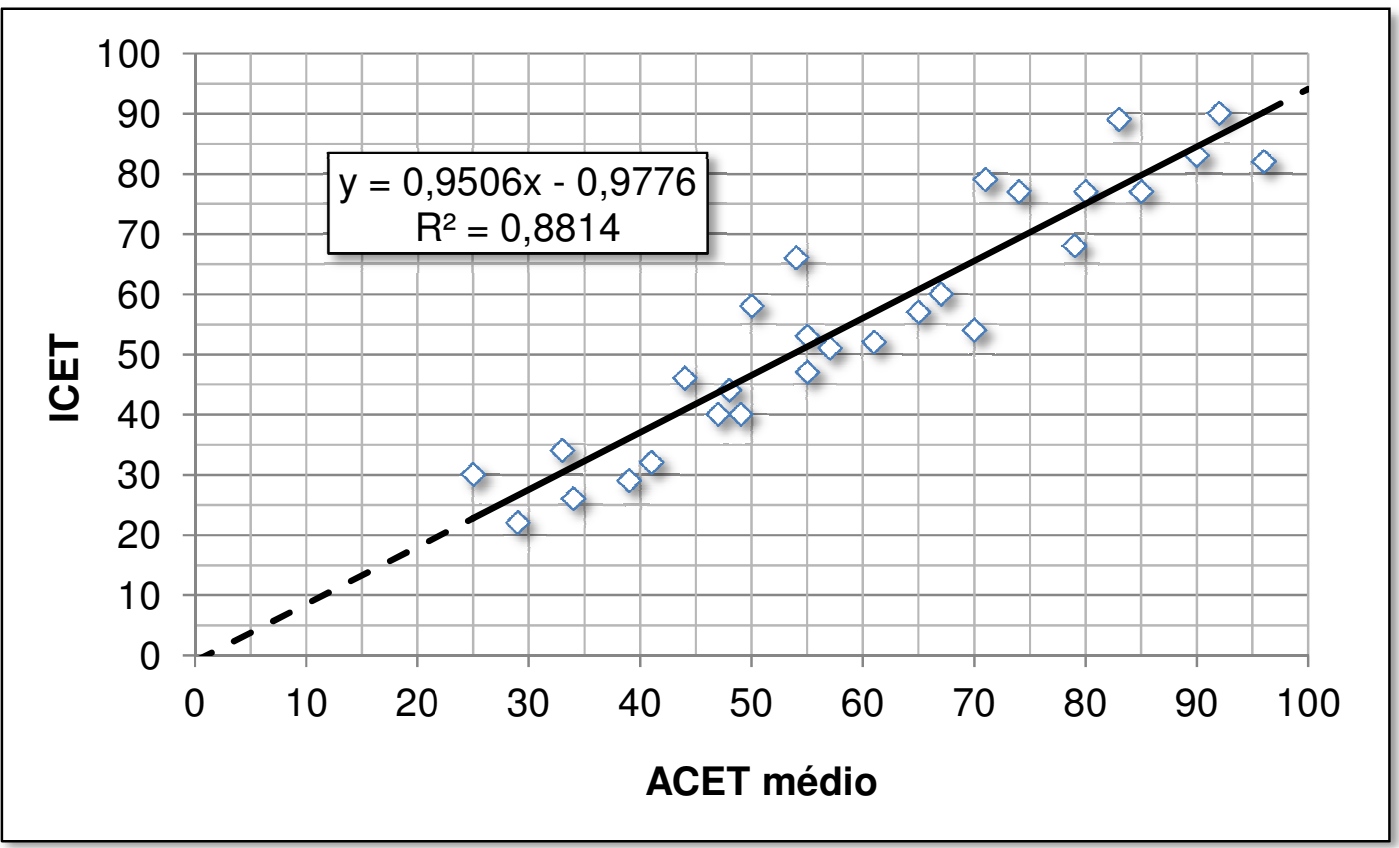

Figura 5.28: Relação entre ICET e ACET. 


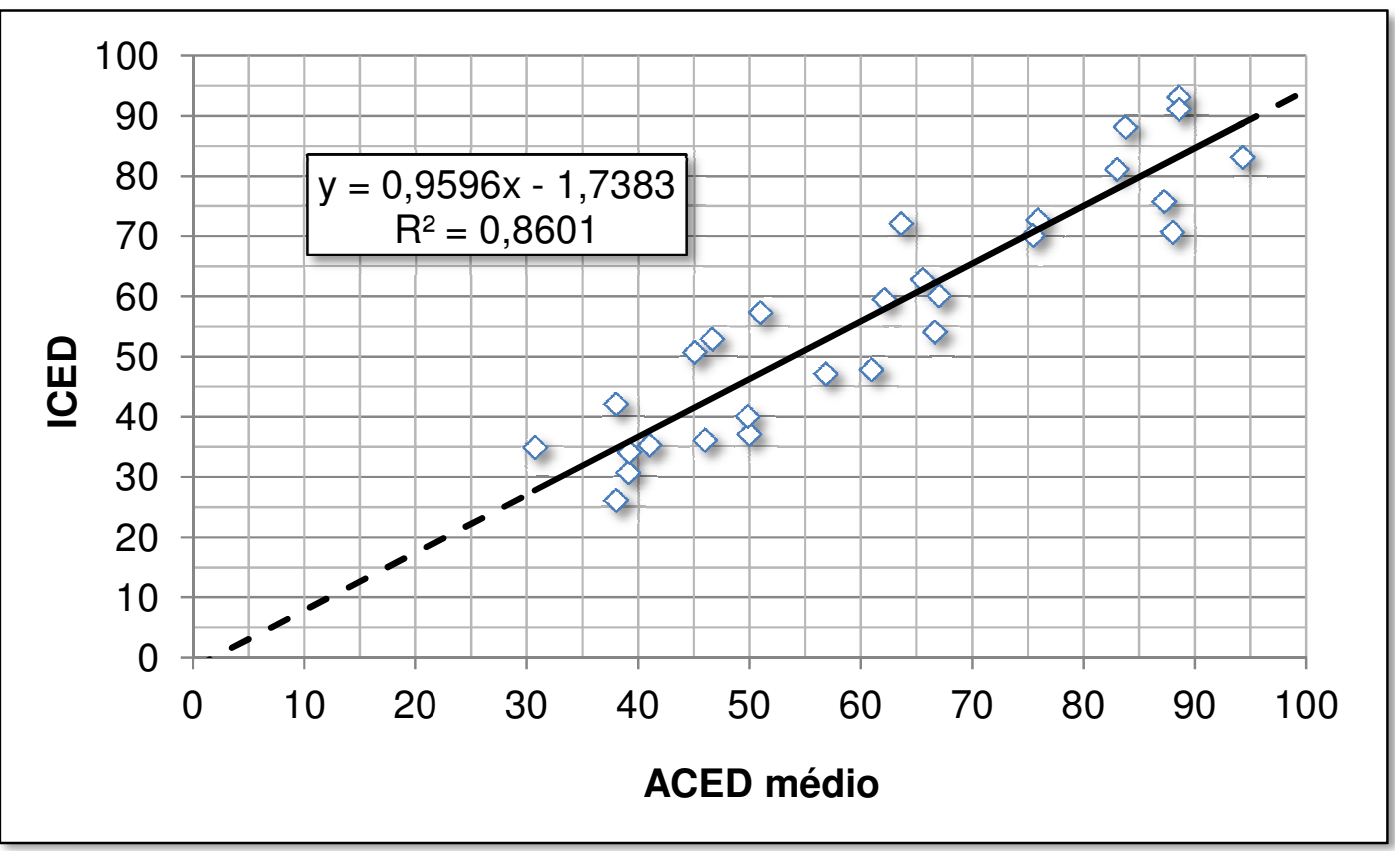

Figura 5.29: Relação entre ICED e ACED.

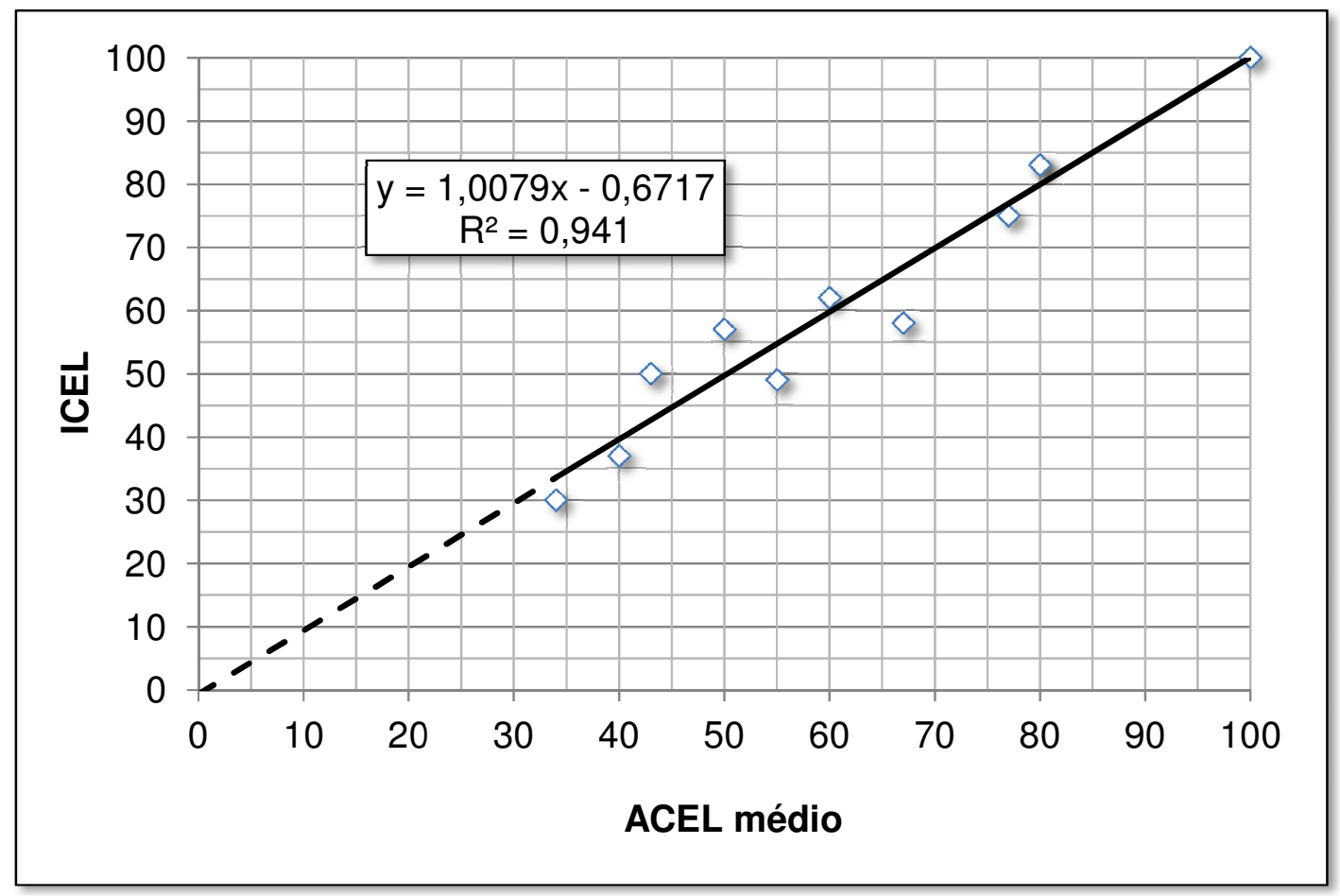

Figura 5.30: Relação entre ICEL e ACEL. 
A comparação entre os valores avaliados e os valores calculados se mostrou bastante consistente. Em todos os casos o coeficiente de determinação ficou acima de 0,85 e a diferença média entre os valores avaliados e os calculados não passou de 3 pontos (Figuras 5.28 a 5.30).

Uzarski (1991) apresenta um modelo para índices globais de condição com base em 3 termos, sendo cada um representante de um índice individual de condição estrutural. Por meio de regressão linear, o autor conseguiu determinar o peso com que cada índice individual afetava a condição global da via (Equação 5.10).

$$
\mathrm{IG}=5,54+0,58 \cdot\left(I C_{b}\right)+0,49 \cdot\left(I C_{m}\right)-0,10 \cdot\left(I C_{a}\right)
$$

Sendo "IG" o índice global de condição, "IC" os índices individuais, "b" o grupo de defeitos que apresenta índice mais baixo, "m" o grupo de defeitos que apresenta índice médio e "a" o mais alto.

Com este modelo foi possível concluir que o índice de grupo que apresentasse valor mais baixo influenciava de forma mais incisiva no índice global. Embora o modelo apresentasse coeficiente de determinação de 0,9 , ele não era capaz de servir para qualificar estruturalmente um pavimento de forma adequada, uma vez que não tinha fundo de escala igual a 0 e, principalmente, permitia valores negativos.

Usando o método da tentativa e erro, Uzarski chegou à Equação 5.11, em substituição à Equação 5.10 e, dessa forma, conseguiu-se sanar os problemas de escala.

$$
\mathrm{IG}=0,50 \cdot\left(I C_{b}\right)+0,35 \cdot\left(I C_{m}\right)-0,15 \cdot\left(I C_{a}\right)
$$


De acordo com Uzarski (1991), a Equação 5.11 tem coeficiente de determinação de 0,86 e a análise das médias das avaliações com relação aos índices é de 0 , o que mostra boa resposta.

Com base nessa premissa de pesos diferentes para cada índice individual que compõem o índice global e que o índice individual que tem menor valor, também tem maior influência no índice global, procurou-se determinar constantes que melhor representassem a realidade da malha estudada. Para isso foram selecionados 9 trechos de 250 metros, em locais aleatórios da malha estudada, nos quais foram avaliados os índices de grupos de defeitos e, com eles, encontrados os pesos para cada grupo de defeito que conduz à melhor resposta da relação entre 0 índice estrutural global e a avaliação estrutural global. A Tabela 5.46 mostra os valores determinados para os índices de cada grupo de defeitos e as curvas propostas nesta pesquisa e a média das avaliações globais (ACEG) feitas pelo painel de avaliadores nos trechos estudados.

O Índice de Condição Estrutural Geral (ICEG) gerado a partir do modelo de regressão linear que considera os três grupos de defeitos ponderados com peso maior para o grupo com menor nota e peso menor para o grupo com maior nota (Equação 5.3), usado juntamente com as curvas de ponderação propostas nesta pesquisa pôde-se traçar a curva da Figura 5.31. 
Tabela 5.46: Valores de ICET, ICED, ICEL e ACEG.

\begin{tabular}{c|c|c|c|c}
\hline \multirow{2}{*}{ Trecho } & \multicolumn{2}{|c|}{ Curvas Propostas } & \multirow{2}{*}{ ACEG } \\
\cline { 2 - 4 } & ICET & ICED & ICEL & \\
\hline 1 & 79 & 65 & 55 & 60 \\
2 & 65 & 44 & 40 & 45 \\
3 & 87 & 85 & 67 & 76 \\
4 & 73 & 65 & 50 & 54 \\
5 & 80 & 74 & 69 & 73 \\
6 & 77 & 65 & 60 & 65 \\
7 & 82 & 71 & 55 & 61 \\
8 & 85 & 76 & 62 & 65 \\
9 & 79 & 57 & 54 & 59 \\
10 & 90 & 75 & 64 & 76 \\
11 & 66 & 47 & 45 & 50 \\
12 & 78 & 75 & 65 & 69 \\
13 & 92 & 80 & 70 & 79 \\
14 & 79 & 69 & 62 & 70 \\
15 & 90 & 82 & 74 & 84 \\
\hline
\end{tabular}




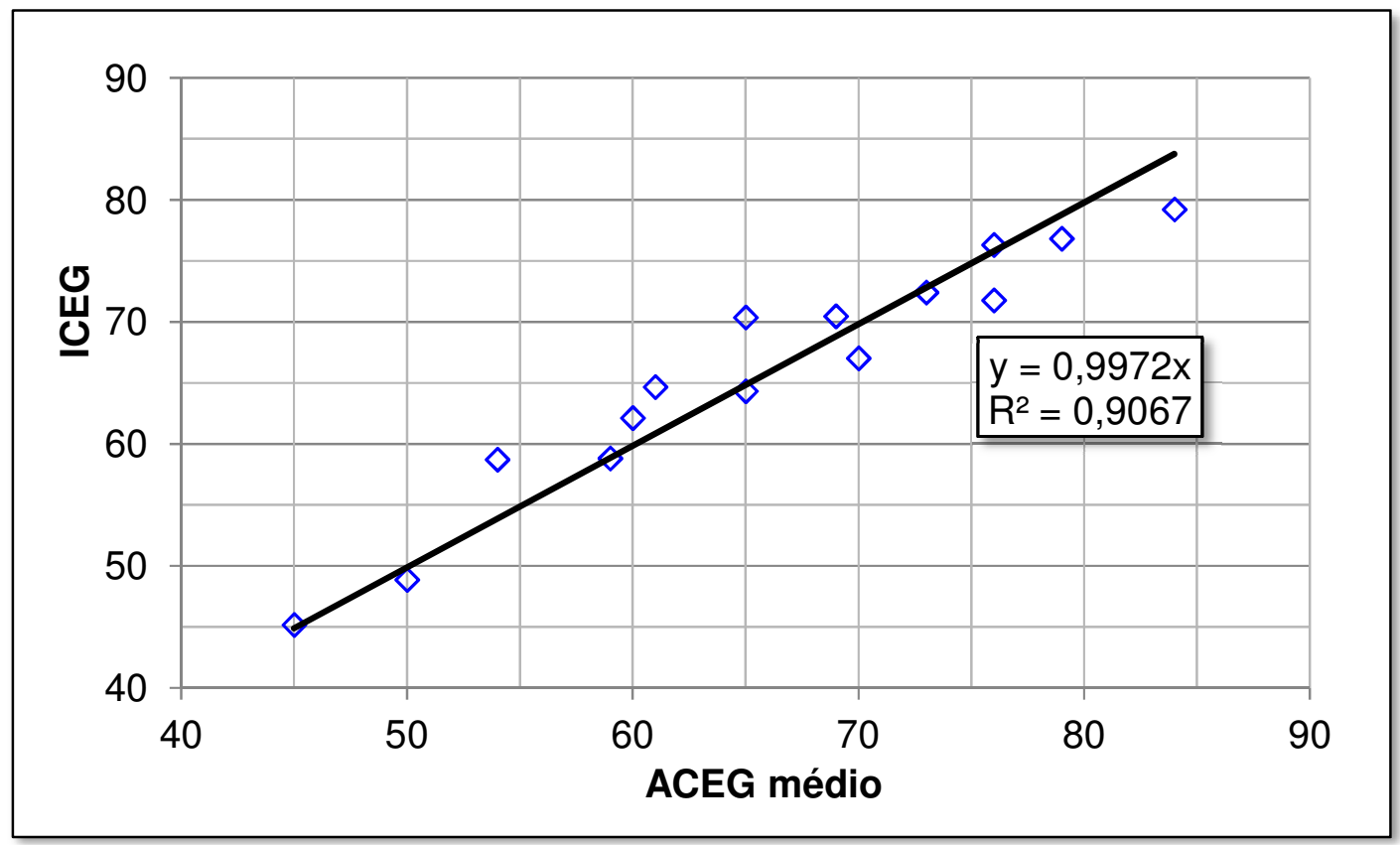

Figura 5.31. Relação entre ICEG e ACEG considerando as curvas de ponderação propostas.

As curvas de ponderação propostas para os defeitos considerados nos 3 grupos distintos e usadas para calcular o ICEG proporcionaram um coeficiente de regressão de 0,91 e diferença entre as médias dos valores calculados para os medidos de 0 (Figura 5.31), o que indica excelente correlação.

A escala que representa a qualidade da via (Figura 5.32 e Tabela 5.47) foi construída com as classes definidas em função da severidade dos defeitos (item 3.2 do Capítulo 3) e permite analisar a qualidade estrutural da via férrea com relação a cada grupo de defeitos ou a condição global. 


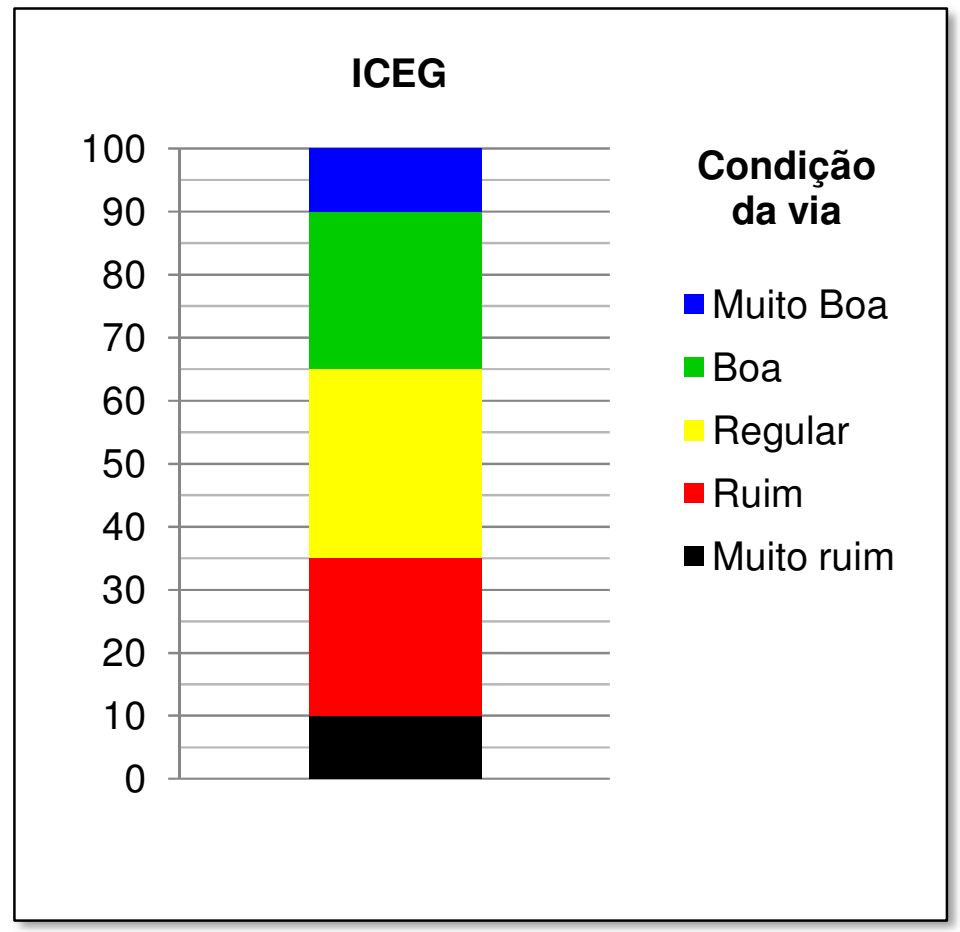

Figura 5.32: Qualidade estrutural da via.

Tabela 5.47: Atividades de M\&R recomendadas para a superestrutura.

\begin{tabular}{c|c|c}
\hline ICET, ICED, ICEL ou ICEG & Condição da via & M\&R recomendada \\
\hline 90 a 100 & Muito boa & Nada a fazer \\
65 a 90 & Boa & Manutenção preventiva \\
35 a 65 & Regular & Manutenção corretiva \\
10 a 35 & Ruim & Reabilitação \\
0 a 10 & Muito ruim & Reconstrução \\
\hline
\end{tabular}

Para a escolha do tipo de intervenção adequada, podem ser construídas árvores de decisão em função dos índices estruturais (Figura 5.33). 


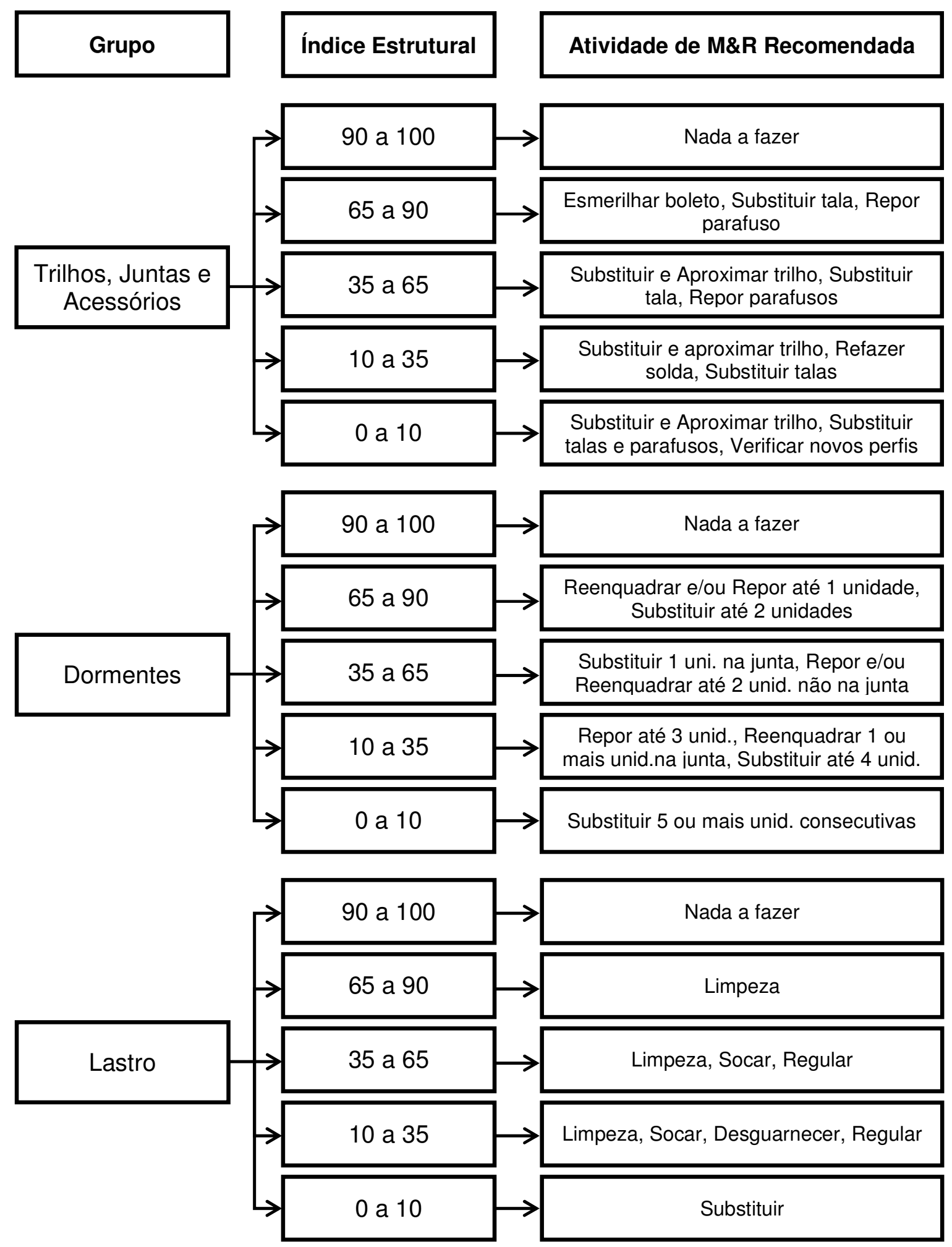

Figura 5.33: Árvore de decisão para defeitos estruturais. 


\section{Conclusões e sugestões}

Com a análise da coleta e processamento dos dados, entrevistas e modelos propostos, pôde-se concluir que:

- É possível implantar sistemas de gerência nas ferrovias brasileiras. Para isso é necessário analisar tanto a geometria da via, quanto os elementos da superestrutura;

- As manutenções feitas de forma cíclica ou programada diminuem a possibilidade da via ser fechada por problemas geométricos ou estruturais. Nos trechos estudados, não houve fechamento das vias desde a implantação da manutenção cíclica; 
- A coleta de dados por caminhamento é trabalhosa, no entanto permite contato direto com a superestrutura da via, seus defeitos e estado de degradação. Os dados coletados dessa forma se mostraram bastante consistentes e efetivos para formulação de modelos;

- A análise por caminhamento permitiu identificar alguns problemas que não seriam identificados pela análise automatizada, como é o caso dos trechos com substituição de trilhos T-45 por T-57, que tornou a estrutura mais rígida e melhorou alguns parâmetros geométricos, mesmo em locais com problemas nos dormentes e/ou lastro e/ou acessórios, o que pode mascarar alguns resultados. Esse tipo de análise permitiu que trechos como esse fossem excluídos da pesquisa;

- As entrevistas se mostraram um ponto importante em sistemas de gerência de ferrovias, pois completaram algumas lacunas que não puderam ser preenchidas com informações medidas;

- Os conceitos e preceitos aplicados em gerência de pavimentos rodoviários podem ser transplantados, em grande parte, para formulação de sistemas de gerência de ferrovias;

- A qualidade geométrica da via, bem como a evolução dos defeitos geométricos pode ser analisada com o uso de Índices de Qualidade; tal qual a superestrutura da via pode ser analisada por Índices de Condição;

- Com base no modelo estrutural é possível concluir que o índice de grupo que apresenta valor mais baixo influencia de forma mais incisiva no índice global; 
- É possível recomendar intervenções de manutenção e reabilitação em função dos Índices propostos, assim como o melhor momento de realizá-las. Desse modo, o tráfego de trens sofre a mínima interferência possível;

- Há necessidade de transparência com relação ao estado da malha férrea brasileira. Os dados de qualidade das vias, que deveriam ser de domínio público, só foram conseguidos mediante contrato de confidencialidade.

Como complemento à pesquisa e sugestões para pesquisas futuras, recomenda-se:

- Analisar a infraestrutura das ferrovias, sobretudo o subleito e os sistemas de drenagem;

- Estudar de forma criteriosa o ciclo de vida dos materiais componentes da via férrea;

- Estudar modelos de desempenho, com base na experiência rodoviária, que representem as ferrovias brasileiras;

- Propor métodos de avaliação da qualidade das ferrovias com base em trechos aleatórios e não somente a toda extensão da malha;

- Propor outros usos para os Índices de Qualidade e Condição, de modo a incorporar sua resposta aos orçamentos necessários;

- Incluir a influência das passagens em nível no desempenho da ferrovia. 



\section{EFERÊNCIAS}

ASSOCIAÇÃO BRASILEIRA DE NORMAS TÉCNICAS. ABNT NBR-7590: Trilho "Vignole". Rio de Janeiro: 1991.

ABNT NBR-7511: Dormente de madeira para via férrea. Rio de Janeiro, 2005.

AMERICAN RAILWAY ENGINEERING AND MAINTENANCE-OF-WAY ASSOCIATION - AREMA. Manual for Railway Engineering. Lanham, Maryland: 2012.

ANDERSSON, M. Strategic Planning of Track Maintenance - State of the Art. Report TRITA-INFRA 02-035, Royal Institute of Technology, Department of Infrastructure, Stockholm: KTH, 2002.

ANPTRILHOS (2012). A importância da ferrovia para o desenvolvimento econômico. Disponível em: http://www.anptrilhos.org.br/index.php/noticias/572-aimportancia-da-ferrovia-para-o-desenvolvimento-economico. Acesso em: 17 abril 2012.

APS, M. Análise de métodos de avaliação de superfície de pavimentos asfálticos em vias urbanas utilizando o método do $\mathbf{P C l}$. Dissertação (Mestrado). Escola Politécnica, Universidade de São Paulo. São Paulo: 2000.

BHASKAR, D.V; RANJENDRAN, S.; SOOD, S.V.B. Implementation of track management system in Bangalore Dvn and suggestions for improvements. Indian Railways. Nova Delhi: 2010. 
BORGES NETO, C. B. Manual didático de Ferrovias. Departamento de Transportes. Setor de Tecnologia. Universidade Federal do Paraná. 193p. Curitiba, Paraná: 2010.

BRASIL TRILHOS. Catálogos. Disponível em: http://www.brasiltrilhos.com.br/. Acesso em: Janeiro de 2011.

BRINA, H. L. (1979). Estradas de ferro - 1ํ Volume - Via Permanente. Ed. LTC. 211p. Rio de Janeiro: 1979.

CIA. Central Intelligency Agency. Disponível em: www.cia.gov/. Acesso em: 16 abril 2012.

CN. Canadian National Railways. Safety Management System. Disponível em: www.cn.ca. Acesso em: janeiro de 2012.

COMPANHIA VALE DO RIO DOCE - CVRD. Manual Técnico de Via Permanente. 362p. Disponível em: www.valec.gov.br.

CONFEDERAÇÃO NACIONAL DOS TRANSPORTES - CNT. Pesquisa CNT de Ferrovias 2011. Disponível em: www.cnt.gov.br. Acesso em: 15 de abril de 2012.

CONFEDERAÇÃO NACIONAL DOS TRANSPORTES - CNT. Anuário estatístico. Disponível em: www.cnt.gov.br. Acesso em: 15 de abril de 2012.

DFT. Department for transport. http://www.dft.gov.uk/ Acesso em: 16 de abril de 2012.

DEPARTAMENTO NACIONAL DE INFRAESTRUTURA DE TRANSPORTES - DNIT (2011). Glossário de termos ferroviários. Disponível em: <http://www1.dnit.gov.br/aplweb/sis_glossario/Consulta.asp. 2011>. Acesso em: 12 de maio de 2011. 
EBERSÖHN, W.; CONRAD, J.R. Implementing a railway infraestruture maintenance system. Amtrak, Washington, D.C.: 2003.

FEDERAL RAILROAD ADMINISTRATION - FRA. Federal Track Safety Standards Fact Sheets. Washington, D.C.: 2008.

FERNANDES JR, J.L.; ODA, S.; ZERBINI, L.F. Defeitos e atividades de manutenção e reabilitação em pavimentos asfálticos. Gráfica EESC USP. Reimpressão. São Carlos: 2006.

HAAS, R.; HUDSON, W.R.; ZANIEWSKI, J. Modern Pavement Management. 577p. Malaba, Florida, EUA: Krieger Publishing Company, 1994.

HYSLIP, J.P; TROSINO, M.J.; SELIG; E.T. Fractal analysis of geometry data. Federal Railway Administration. Alexandria, Va.: 2002.

IR. Indian Railways. Disponível em: http://www.indianrailways.gov.in/. Acesso em 16 de abril de 2012.

LI, D.; SALAHIFAR, T.; MALONE JR., J.; KALAY, F.K. Development of performance-based track geometry inspection. 7th International heavy haul conference. p. 461-465. Brisbane, Austrália: 2001.

MADEJSKI, J.; GRABOZYK, J. Continuous geometry measurement for diagnostics of tracks and switches. Silesian University of Technology. Gliwice, Poland: 2000.

MEDINA, J. Mecânica dos Pavimentos. 380p. Rio de Janeiro: Ed. UFRJ, 1997.

MEDINA, J.; MOTTA, L.M.G. Mecânica dos Pavimentos. 2ª Edição. 570p. Rio de Janeiro: Ed. UFRJ. Rio de Janeiro, 2006.

MR. The Ministry of Railway of the People's Republic of China. Disponível em: www.china-mor.gov.cn. Acesso em: 16 abril 2012. 
MUNDREY, J.S. Railway track engineering. Track Tolerance, track inspection, and track recording. p. 481-522. Índia: McGraw-Hill, 2003. Disponível em: http://booklens.com/mundrey/railway-track-engineering. Acesso em 10 de março de 2009.

OFFICE FOR RESEARCH AND EXPERIMENTS OF THE INTERNATIONAL UNION OF RAILWAYS - ORE. Quantitative Evaluation of Geometry Track Parameters Determining Vehicle Behavior: Introductory Study to the Problem of Assessing Track Geometry on the Basis of Vehicle Response. Report № 1. Netherlands: 1991.

OTT, R.L; LONGNECKER, M. An Introduction to Statistical Methods and Data Analysis. 5ª Edição. 1152p.Pacific Grove, EUA: Editora Duxbury, 2001.

PANTIGOSO, J. F. G. Uso de Sistemas de Informação Geográfica para a Integração da Gerência de Pavimentos Urbanos com as Atividades das Concessionárias de Serviços Públicos. Dissertação (Mestrado) - Escola de Engenharia de São Carlos, Universidade de São Paulo. São Carlos: 1998.

PETERSON, D.E. Pavement Management Practices. National Cooperative Research Program. Synthesis of Highway Practice, 135. 139 p..Transportation Research Board, 1987.

PNLT. Plano Nacional de Logística de Transportes - 2009. Disponível em: http://www.transportes.gov.br/conteudo/3280. Acesso em: 10 de abril de 2012.

RAC. Railroad Association of Canada. Disponível em: http://www.railcan.ca/. Acesso em: 16 de abril de 2012. 
RAIL INDUSTRY SAFETY AND STANDARD BOARD - RISSB. Railway of Australia Manual. Section 1 - Civil. Kingston, Australia: 2001.

RFFSA. Histórico da extinta Rede Ferroviária Federal S.A. Disponível em: http://www.rffsa.gov.br/. Acesso em 12 de abril de 2011.

RODRIGUES, C.A. (2001). Contribuição ao planejamento da manutenção preditiva da superestrutura ferroviária. Tese (Doutorado). Universidade Federal do Rio de Janeiro - COPPE/UFRJ. Rio de Janeiro: 2001.

RR. Russian Railways. Disponível em: http://eng.rzd.ru/maineng/public/rzdeng?STRUCTURE ID=704. Acesso em: 17 abril 2012.

SADEGHI, J.; AKBARI, B. Field investigation on effect of railway track geometry parameters on rail wear. International Journal of Zhejiang University, Science A, 7 (11), p. 1846-1855. China: 2006.

SHAHIN, M.Y; DARTER, M.I.; KOHN, S.D. Development of a Pavement Maintenance Management System. Volume I. Airfield Pavement Condition Rating. Technical Report TR-76-27. Estados Unidos da América: 1976.

SHAHIN, M. Y.; KHON, S. D. Development of a pavement condition rating procedure for roads, streets and parking lots. Vol.1 - Distress Identification Manual. CERL-TR-M-268. U.S. Army, 1979a.

SHAHIN, M. Y.; KHON, S. D. Development of a pavement condition rating procedure for roads, streets and parking lots. Vol.2 - Distress Identification Manual. CERL-TR-M-268. U.S. Army, 1979b.

SILVA, E.T.F. Análise da evolução dos defeitos da via permanente da MRS para planejamento de intervenções preditivas de manutenção. Instituto Militar de Engenharia - IME. Monografia do curso de especialização em transporte ferroviário de cargas. 73p. Rio de Janeiro: 2006. 
SILVA, L.F.M. Fundamentos teórico-experimentais da mecânica dos pavimentos ferroviários e um esboço de um sistema de gerência aplicado à manutenção da via permanente. Universidade Federal do Rio de Janeiro COPPE. Tese de Doutorado. 333p. Rio de Janeiro: 2002.

UNITED STATES ARMY CONSTRUCTION ENGINEERING RESARCH LABORATORIES - USACERL. RAILER User Guide. Illinois: 1998.

UZARSKI, D.R. Development of a Track Structure Condictioon Index (TSCI). Universidade de Illinois. Tese de doutorado. Illinois: 1991.

WANG, Z.; HAN, L. D. Pavement distress - deduct value determination: a new approach. Road \& Transport Research. Volume 11. Número 1. 2002.

ZHANG, Y.J.; EL-SIBAIE, M.; LEE, S. FRA track quality indices and distribution characteristics. Proceedings, AREMA Annual Conference. Lanham, Md.: 2004. 
ANEXO A
PROCEDIMENTO PARA DETERMINAÇÃO DO
VALOR DE PONDERAĈ̃O CORRIGIDO E DOS
İNDICES ESTRUTURAIS 

Neste anexo é apresentado um exemplo de como pode ser determinado o valor dedutível corrigido e índice estrutural. O procedimento para determinação desses parâmetros é análogo para o grupo de defeitos "Dormente".

Suponham-se os seguintes defeitos referentes ao grupo de defeitos "Trilho, juntas e ligações" no trecho em estudo:

- $\mathrm{a}=1$ defeito de trilho de severidade baixa;

- $b=1$ defeito de trilho de severidade média;

- $\mathrm{c}=2$ defeitos de junta de severidade baixa;

- $\mathrm{d}=2$ defeitos de junta de severidade média;

- $e=9$ defeitos de fixação.

O primeiro passo é a definição das densidades (D) dos defeitos. Considerando-se 6 juntas, 6 trilhos e 60 dormentes, tem-se:

- $D_{a}=1 / 6=16,67 \%$ (página 44$)$

- $D_{b}=1 / 6=16,67 \%$ (página 46)

- $D_{c}=2 / 6=33,33 \%$ (página 46$)$

- $D_{d}=2 / 6=33,33 \%$ (página 46$)$

- $D_{e}=9 /(60 \cdot 4)=3,75 \%($ página 47$)$

O segundo passo é a determinação dos valores de ponderação (VP) baseados nas curvas de ponderação propostas:

- $\mathrm{VP}_{\mathrm{a}}=16$ (Figura 5.18)

- $\mathrm{VP}_{\mathrm{b}}=25$ (Figura 5.19)

- $\mathrm{VP}_{\mathrm{c}}=33$ (Figura 5.21)

- $\mathrm{VP}_{\mathrm{d}}=53$ (Figura 5.22)

- $\mathrm{VP}_{\mathrm{e}}=6$ (Figura 5.25) 
Em seguida, listar os valores de ponderação em ordem decrescente por coluna (Tabela A1).

Tabela A1: Valores de ponderação.

\begin{tabular}{c|ccccc}
\hline Coluna & \multicolumn{5}{|c}{ Valores de ponderação } \\
\hline 1 & 53 & 33 & 25 & 16 & 6 \\
\hline
\end{tabular}

Determinar o número máximo de valores de ponderação $(\mathrm{m})$, por meio da Equação A1.

$$
m=1+\left(\frac{9}{x}\right) \cdot(100-M V D)
$$

Sendo $x=98$, baseado no valor de corte de 2 e MVD $=$ máximo valor de ponderação.

Deste modo, no exemplo, tem-se que:

$$
m=1+\left(\frac{9}{98}\right) \cdot(100-53)=5,32
$$

Sendo "m" maior que o número de valores dedutíveis $(q=5)$, não há necessidade de descartar qualquer valor.

Seguindo-se a isso, colocar as demais linhas na Tabela $A 1$, substituindo-se os menores valores por $2(=100-x)$ (Tabela A2). 
Tabela A2: Escalonamento dos valores de ponderação.

\begin{tabular}{c|ccccc}
\hline Coluna & \multicolumn{5}{|c}{ Valores de ponderação } \\
\hline 1 & 53 & 33 & 25 & 16 & 6 \\
\hline 2 & 53 & 33 & 25 & 16 & 2 \\
\hline 3 & 53 & 33 & 25 & 2 & 2 \\
\hline 4 & 53 & 33 & 2 & 2 & 2 \\
\hline 5 & 53 & 2 & 2 & 2 & 2 \\
\hline
\end{tabular}

O passo seguinte é a determinação de cada Valor Total de Ponderação (VTP), que é a soma dos valores de ponderação individuais em cada linha. Analisando-se conjuntamente o "VTP", "q" e a Curva de Correção (Figura 5.26), é possível encontrar o Valor Corrigido de Ponderação (VCP). No exemplo, os valores são apresentados na Tabela A3.

Tabela A3. Valores Totais de Ponderação e Valores Corrigidos de Ponderação.

\begin{tabular}{c|ccccc|c|c|c}
\hline Coluna & \multicolumn{5}{|c|}{ Valores de ponderação } & VTP & q & VCP \\
\hline 1 & 53 & 33 & 25 & 16 & 6 & 133 & 5 & 52 \\
\hline 2 & 53 & 33 & 25 & 16 & 2 & 129 & 4 & 56 \\
\hline 3 & 53 & 33 & 25 & 2 & 2 & 115 & 3 & 58 \\
\hline 4 & 53 & 33 & 2 & 2 & 2 & 92 & 2 & 58 \\
\hline 5 & 53 & 2 & 2 & 2 & 2 & 61 & 1 & 61 \\
\hline
\end{tabular}

O valor do Índice de condição estrutural do grupo "Trilhos, Juntas e Acessórios" (ICET) é dado pela Equação A2. 


$$
I C E T=100-V C P_{\text {máx }}
$$

Sendo $\mathrm{VCP}_{\text {máx }}$ o maior valor encontrado entre os Valores Corrigidos de Ponderação. Assim, a Equação A2 assume os valores:

$$
I C E T=100-61=49
$$

De acordo com a escala proposta (Figura 5.32), a condição estrutural do grupo "Trilhos, Juntas e Acessórios" é "Regular". A Tabela 5.47 indica "Manutenção Corretiva" como intervenção; o que, segundo a Figura 5.33, deve ser: "Substituir e aproximar trilho, Substituir tala, Repor parafusos".

Considerando-se que o grupo de defeitos "Dormentes" apresente um ICED de 66, considerado "Bom" (Figura 5.32), recomendado "Manutenção Preventiva (Tabela 5.47)" e intervenções do tipo "Reenquadrar e/ou Repor até 1 unidade, Substituir até 2 unidades" (Figura 5.33), considerando-se, ainda, que o grupo de defeitos "Lastro" apresente um ICEL de 45, considerado "Bom" (Figura 5.32), recomendado "Manutenção Corretiva" (Tabela 5.47) e intervenções do tipo "Limpeza, Socar, Regular" (Figura 5.33), é possível calcular o valor de ICEG por intermédio da Equação 5.11.

$$
\mathrm{ICEG}=0,50 \cdot(45)+0,35 \cdot(49)-0,15 \cdot(66) \cong 40
$$

O valor de ICEG de aproximadamente 40 indica que a qualidade estrutural da via é "Regular" e que Manutenções Corretivas devem ser agendadas o mais rápido possível. 
A pêndicea TERMO DE CONFIDENCIALIDADE 

ESNER SERENI ILDEFONSO, brasileiro, portador do RG $n^{\circ}$. inscrito no CPF sob $\mathrm{n}^{0}$. residente e domiciliado na Rua São doão, 81, Apto 702, Zona 7, Maringá/PR, CEP 87030-200, doravante designado apenas "RECEPTOR", vem prestar o que segue:

\section{CONSIDERANDO QUE:}

(i) O RECEPTOR, em razão da tese de doutorado que está desenvolvendo relacionada à manutenção da via férrea, necessita de acesso ao banco de dados disponivel acerca da condição da ferrovia sob concessão da AШ - AMÉRICA LATINA LOGISTICA SIA, pessoa juridica de direito privado, inscrita no CNPJ $n^{0}$. 02.387.241/0001-60, estabelecida na Rua Emílio Bertolini, 100, Vila Oficinas, em Curitiba/PR, CEP 82920-030;

(ii) para a realização da pesquisa, o RECEPTOR tomará conhecimento de dados sigilosos referentes aos negócios e atividades da ALL;

Resolve o Receptor firmar o presente Termo de Confidencialidade ("Termo") que será regido pelos seguintes artigos e condições:

\section{DAS INFORMAÇÕES CONFIDENCIAIS:}

1. Constitui objeto do presente instrumento o sigilo absoluto e a proteção às Informações Confidenciais trocadas entre as partes, consistentes nos dados comerciais, industriais, fiscais, jurídicos, processuais, patrimoniais e quaisquer outros, considerando-se todas as formas de apresentação, seja escrita, verbal, telefônica, visual, digital, eletrônica ou qualquer outra que atinja o fim de transmitir informação.

2. O presente Termo de Confidencialidade visa assegurar a inviolabilidade das Informações Confidenciais, que são de interesse restrito das partes.

3. A partir da assinatura do presente instrumento, o RECEPTOR fica automaticamente obrigado a guardar sigilo absoluto dos dados e informações obtidas, nos termos previstos neste contrato. 
3.1. Além da obrigaçăo de guardar sigilo absoluto dos dados e informações obtidas, o RECETCR deverá cuidar para que as mesmas não sejam divulgadas, extraviadas, deletadas, violadas, alteradas e/ou acessadas por terceiros, tampouco permitir que tais informações confidenciais sejam utilizadas indevidamente, por terceiros estranhos a este Termo ou em atividades diversas que não as aqui previstas;

3.2. O RECEPTOR obriga-se a näo tomar qualquer medida que vise obter para si ou para outrem os direitos de propriedade industrial e segredos profissionais que venham a ser transmitidos;

3.3 O RECEPTOR compromete-se a comunicar os termos e condições deste contrato a seus empregados, subcontratados ou prepostos que tiverem acesso às Informações Confidenciais, sendo solidária a responsabilidade, mas näo eximindo nem diminuindo a da parte signatária deste instrumento;

3.4. OREOETOR das Informaçães Confidenciais adotará as mesmas medidas de proteção que daria aos seus próprios dados e informaçöes confidenciais, objetivando manter o sigilo das mesmas;

3.5 O RECEPTOR concorda em limitar o acesso à Informação Confidencial somente (e tãosomente) àquelas pessoas que tenham necessidade de ter conhecimento de tais Informações Confidenciais, limitado ademais a um número restrito de administradores, empregados, consultores e/ou assessores que, dentro do razoável, requisitem tais informaçōes;

3.6 O RECETOR concorda em limitar o número de cópias das Informaçóes Confidenciais eventualmente a ela divulgadas ao número necessário para o cumprimento dos objetivos previstos neste Acordo;

4. O presente instrumento é pactuado sem prazo determinado, sendo também irretratável e irrenunciável, não podendo ser denunciado pelo RECETCR pois permanecem em vigor todas as condições aqui estipuladas, sendo que a obrigaçäo das partes em guardar sigilo dos dados e das Informações Confidenciais inicia-se a partir da tomada de conhecimento daquelas.

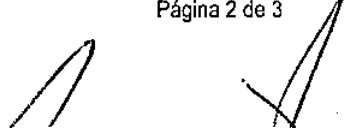


5. O desaumprimento de quaisquer das cláusulas deste Termo, principalmente com relação à perda, alteração ou violação de qualquer informação, implicará na responsabilização civil e criminal do RECEPCR, bem como na multa fixa e irredutivel de $R \$ 500.000,00$ (quinhentos mil reais) em favor da A山, sem prejuizo da indenização das eventuais perdas e danos apuradas.

6. Os herdeiros e sucessores das partes signatárias deste instrumento se obrigam por todas as suas cáuusulas e condições.

7. O presente Termo se aplica a todas as empresas do Grupo ALL.

8. Este Termo deverá ser interpretado e regido em conformidade com as leis do Brasil. o RECETCR elege o foro da comarca de Ouritiba como o único competente para a dirimir as dúvidas oriundas deste instrumento, com a renúncia de qualquer outro, por mais privilegiado que seja.

Curitiba/PR, 2 de julho de 2012.
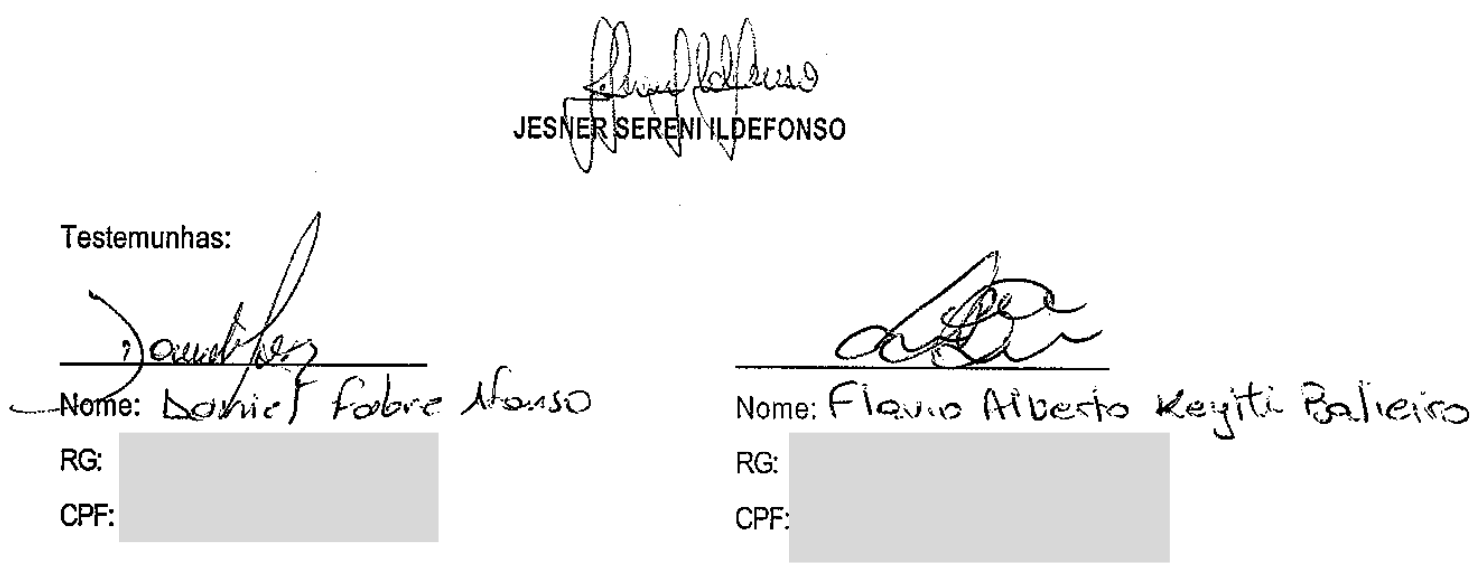